



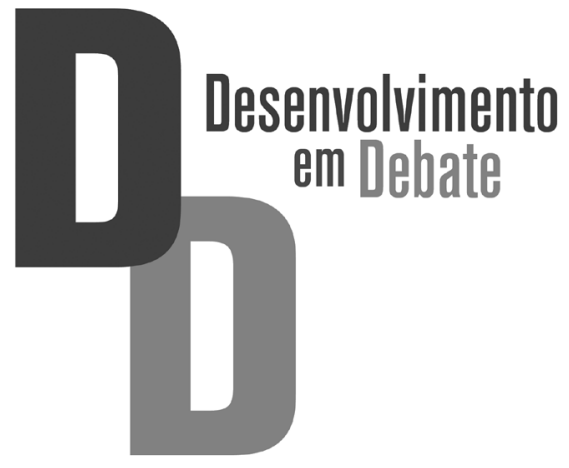

v.8, n.3, setembro-dezembro 2020
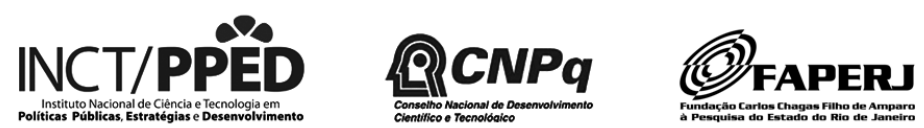

Instituições parceiras do INCT/PPED: UFRJ, UFF, UFRRJ, UFJF, UNICAMP e UERJ 
Desenvolvimento em Debate é uma revista indexada de publicação periódica editada pelo Instituto Nacional de Ciência e Tecnologia em Políticas Públicas, Estratégias e Desenvolvimento. A revista publica artigos originais de pesquisa, ensaios e resenhas relacionados com a temática do desenvolvimento socio-econômico. Énfase é dada a trabalhos que analizam o papel do Estado e das instituições no desenvolvimento, políticas públicas setoriais e estratégias de desenvolvimento, o papel da geopolítica na dinâmica econômica e sustentabilidade ambiental, como também a trabalhos que analisam casos nacionais ou com perspectiva comparada, em particular de países da América Latina. Para tal fim, Desenvolvimento em Debate é publicada três vezes por ano e aceita trabalhos em português, espanhol e inglês. Pelo menos um dos autores deve ter titulação mínima de mestre.

ISSN: 2176-9257 (Online)

Frequência: 3 números por ano

\section{Coordenação INCT/PPED}

Renato Boschi

Ana Célia Castro

\section{Editor-Chefe}

Flavio A. Gaitán (UNILA/INCTPPED)

\section{Editora Associada}

Roberta Rodrigues Marques da

Silva (UFF/INCT-PPED)

\section{Editores de seção}

Andrea Ribeiro (UFF/INCT-PPED)

Carlos Eduardo Santos Pinho

(UNISINOS/INCT-PPED)

Rafael Shoenman de Moura

(INCT-PPED)

\section{Comitê editorial}

Ana Célia Castro (IE-UFRJ)Charles Pesanha (UFRJ)

Renato Boschi (IESP-UERJ) Ignacio Godinho Delgado (UFJF) Maria Antonieta Leopoldi (UFF)

\author{
Conselho editorial \\ Adel Selmi (INRA, France) \\ Alexandre d'Avingon (UFRJ) \\ Antonio Márcio Buainain \\ (Unicamp) \\ Bhaven Sampat (Columbia \\ University, USA) \\ Benjamin Coriat (Université de \\ Paris XIII, France) \\ Carlos Eduardo Young (UFRJ) \\ Carlos Morel (Fiocruz) \\ Celina Souza (UFBA) \\ Charles Pessanha (UFRJ) \\ Cristina Possas (UFRJ) \\ Diego Sanchez Anchochea \\ (University of Oxford, UK) \\ Eduardo Condé (UFJF) \\ Erik Reinert (University of Oslo, \\ Norway) \\ Eli Diniz (UFRJ) \\ Estela Neves (UFRJ)
}

Giovanni Dosi (Scuola Superiore Sant'Anna, Pisa, Italy)

Ha-Joon Chang (University of

Cambridge, UK)

João Alberto de Negri (IPEA)

Jorge Ávila (INPI)

Lionelo Punzo (Universidade de Siena, Italy)

Mario Possas (UFRJ)

Marta Irving (UFRJ)

Peter Evans (University of

California,

Berkeley, USA)

Peter May (UFRRJ)

Renato Boschi (IESP)

Sérgio Salles (Unicamp)

Shulin Gu (University of Beijin,

China)

Valéria da Vinha (UFRJ)

Victor Ranieri (USP)

Contato: revdesenvolvimentoemdebate@gmail.com

Acesse nosso site : http://desenvolvimentoemdebate.ie.ufrj.br

Desenvolvimento em Debate / Ana Célia Castro, Renato Boschi (Coordenadores)

Rio de Janeiro, volume 8, numero 3, 2020

170p.

1. Desenvolvimento 2. Estado 3.Políticas Públicas 4. Variedades do

Capitalismo. 5. BIC 


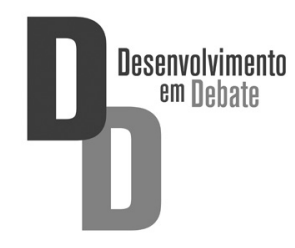

\section{Sumário}

\section{Carta do Editores}

\section{Artigos}

Desenvolvimento e inserção externa da América Latina: o legado de

Hélio Jaguaribe para pensar a autonomia periférica

Leonardo Granato e Katiele Rezes Menger

Dos cadernos ao neobismarckianismo: o primeiro momento de Hélio Jaguaribe

Fernanda Xavier da Silva

O nacional-desenvolvimentismo de Hélio Jaguaribe: nacionalismo, ideologia

e classes sociais

Hélio Cannone e Hugo Müller

Hélio Jaguaribe, pensamento socio-político brasileiro e desenvolvimento: entre textos, contextos e intelectuais

Alessandro André Leme

Desenvolvimento autônomo e crise estrutural do capitalismo

Humberto Machado Lima

Hélio Jaguaribe and Brazil's oil question

Francisco Ebeling 



\section{Carta do Editor}

$\mathrm{O}$ presente volume da Desenvolvimento em Debate inclui textos em homenagem ao professor Hélio Jaguaribe. Intelectual lúcido, comprometido e grande impulsor de iniciativas de pesquisa, Jaguaribe foi um dos grandes pensadores do Brasil contemporâneo. Sua obra perpassa um amplo conjunto de temas, o estudo das relações internacionais com particular ênfase na integração latino-americana, o papel do Estado e das elites - sobretudo, a burguesia industrial - no crescimento econômico, a importância das ideologias, o nacionalismo, entre outros. Contemporâneo de profundas transformaçóes do Brasil e do mundo, Jaguaribe teve a inteligência e sensibilidade para interpretar as mudanças e seu impacto no tema de maior interesse, presente em toda a sua obra: o desenvolvimento do Brasil, em particular, e da América Latina em geral.

$\mathrm{O}$ artigo que abre o volume, de autoria de Leonardo Granato e Katiele Rezer Menger, Desenvolvimento e Inserção Externa da América Latina: O legado de Hélio Jaguaribe para pensar a autonomia periférica, analisa como o autor tratou o tema da autonomia, de grande relevância para o pensamento político e social do pós-II Guerra Mundial na América Latina. Através de uma análise da produção intelectual do Prof. Jaguaribe, os autores demonstram a importância da autonomia como condição do desenvolvimento, isto é, "pensar políticas para o desenvolvimento do Brasil a partir de uma postura própria, reconhecedora da realidade nacional, de seu entorno e os constrangimentos”.

A seguir, Fernanda Xavier, autora do artigo Dos Cadernos ao Neobismarckismo: Oprimeiro momento de Hélio Jaguaribe, analisa, como o título indica, os momentos iniciais da extensa obra do autor homenageado; momento que a autora entende como de "surgimento, maturação e posterior consolidação do projeto desenvolvimentista” de Jaguaribe. Para isso, a autora analisa como mudam as reflexóes e conceitos seja por maturação das idéias do autor ou pelas mudanças do contexto brasileiro e mundial. Xavier reconhece que, apesar das mudanças, "a busca pelo desenvolvimento perpassa toda sua obra, como também é o principal móvel de suas ideias”.

Na sequência, Helio Cannone e Hugo Muller, autores do artigo O Nacional-Desenvolvimentismo de Hélio Jaguaribe: Nacionalismo, ideologia e classes sociais, analisa a produção intelectual do professor Jaguaribe no período de atuação no Instituto Superior de Estudos Brasileiros (ISEB), apresentando as singularidades e divergências em relação a outros intelectuais públicos, no 
contexto de uma "pluralidade de pensamentos nacional-desenvolvimentistas nos anos 50". Apesar de focar, particularmente, nos conceitos de nacionalismo, ideologia, classes sociais e democracia, os autores afirmam que "o programa econômico era umprojeto de nação que articulava diversas áreas da sociedade".

$\mathrm{O}$ artigo de Alessandro Leme, Hélio Jaguaribe, pensamento sócio-politico brasileiro e desenvolvimento: entre textos, contextos e intelectuais, analisa o alcance e impactos da obra de Hélio Jaguaribe sobre o pensamento sóciopolítico brasileiro. Leme mostra que a obra de Jaguaribe e o ISEB são alvos de um amplo número de teses e artigos. Em um segundo momento, problematiza um conjunto de temas da obra do autor homenageado, focando na interpretação do contexto. Leme mostra que Jaguaribe foi influenciado pelo "debate sobre desenvolvimento entre os anos 1930 e 1970, que "marcaram significativamente os problemas que a sociedades brasileira e o capitalismo no Brasil estavam experimentando", como também que foi não apenas um intérprete, mas que procurou indicar caminhos de mudança, à medida que procurou "compreender os entraves, potencialidades e estratégias para superar os constrangimentos do Brasil” para o desenvolvimento nacional.

A seguir, Humberto Machado Lima Junior, autor do artigo Desenvolvimento Autônomo e Crise Estrutural do Capitalismo no Século XXI, analisa o conceito de desenvolvimento autônomo na obra de Hélio Jaguaribe mostrando a atualidade da contribuição e, particularmente, a sua utilidade para pensar a crise estrutural do capitalismo no século XXI. Machado Lima Juniorentende que a crise se relaciona com o "empoderamento do capital sobre o trabalho que repercute na privatização do capital e na estagnação da demanda”. Isso o leva a recuperar elementos em matéria de desenvolvimento autônomo, transformação produtiva, articulação entre classes e políticas de distribuição, todos temas tratados por Jaguaribe.

$\mathrm{O}$ artigo que fecha o volume, Helio Jaguaribe and Brazil Oil's Question, de Francisco Ebeling, analisa um livro clássico do autor que, em suas palavras, causou grande impacto na comunidade desenvolvimentista de pesquisadores brasileiros por sua aparente visão favorável aos investimentos estrangeiros. Ebeling, mostra como o tema é uma constante em vários momentos da produção do professor Jaguaribe. $\mathrm{O}$ artigo contrasta o argumento de que houve uma intenção de questionar o monopólio estatal no setor de petróleo. Comprometido com a perspectiva desenvolvimentista que caracteriza a obra do homenageado, o autor mostra o desígnio de "posicionar o debate sobre a questão petrolífera em bases mais racionais e pragmáticas”. De fato, Jaguaribe reconhecia na Petrobrás, empresa criada nos anos 1950, uma empresa pública 
Considerados em conjunto, os artigos apresentam, desde diferentes perspectivas teóricas, um olhar sobre a obra de um pensador essencial para entender o Brasil, como também a atualidade de seu pensamento. De fato, seu legado é de extraordinária vigência, tanto como a necessidade de continuar pensando o Brasil e seu tempo para analisar os desafios do desenvolvimento autônomo.

Junto a essa edição da Desenvolvimento em Debate, lançamos também o primeiro volume da série Pensadores do Desenvolvimento, uma nova iniciativa da Revista e do Instituto Nacional de Ciência em Tecnologia em Políticas Públicas, Estratégias e Desenvolvimento que visa a recuperar textos e autores essenciais para compreender os desafios do desenvolvimento do Brasil e da América Latina. Nessa ocasião, apresentamos uma seleção de textos do professor Jaguaribe. Desejamos uma boa leitura!

Flavio Gaitán

Editor-Chefe 


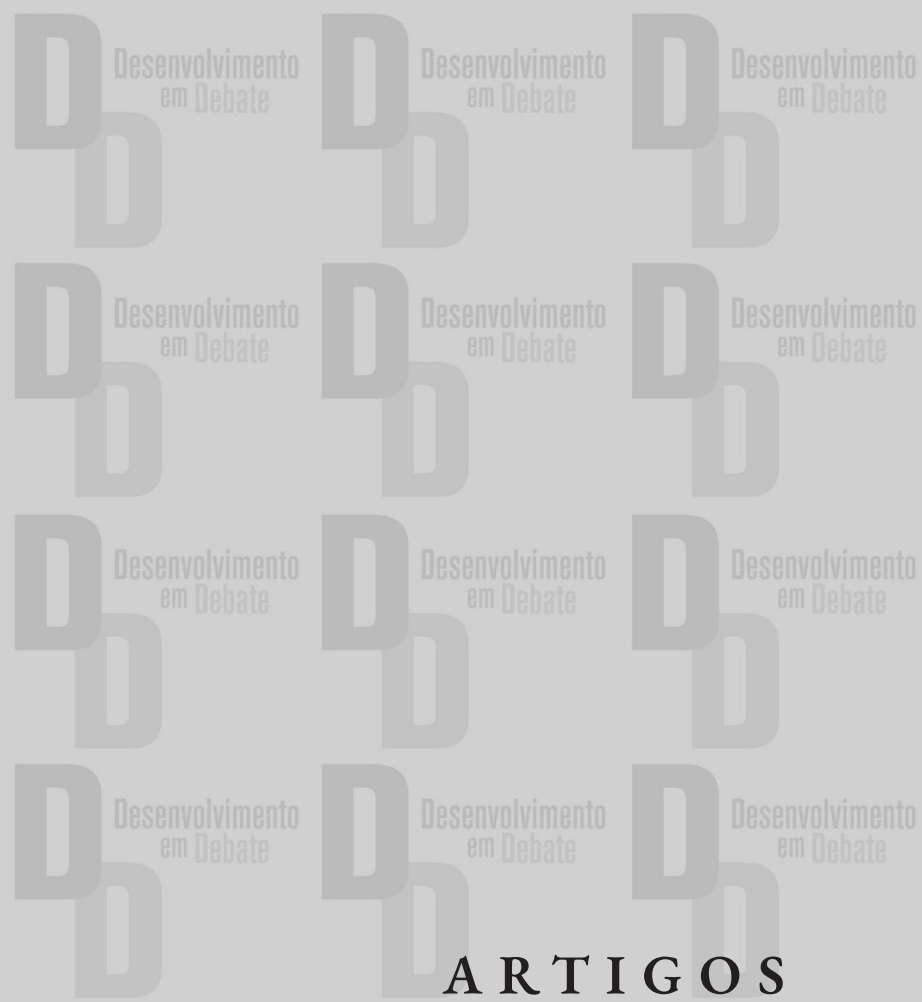

A R T I G O S
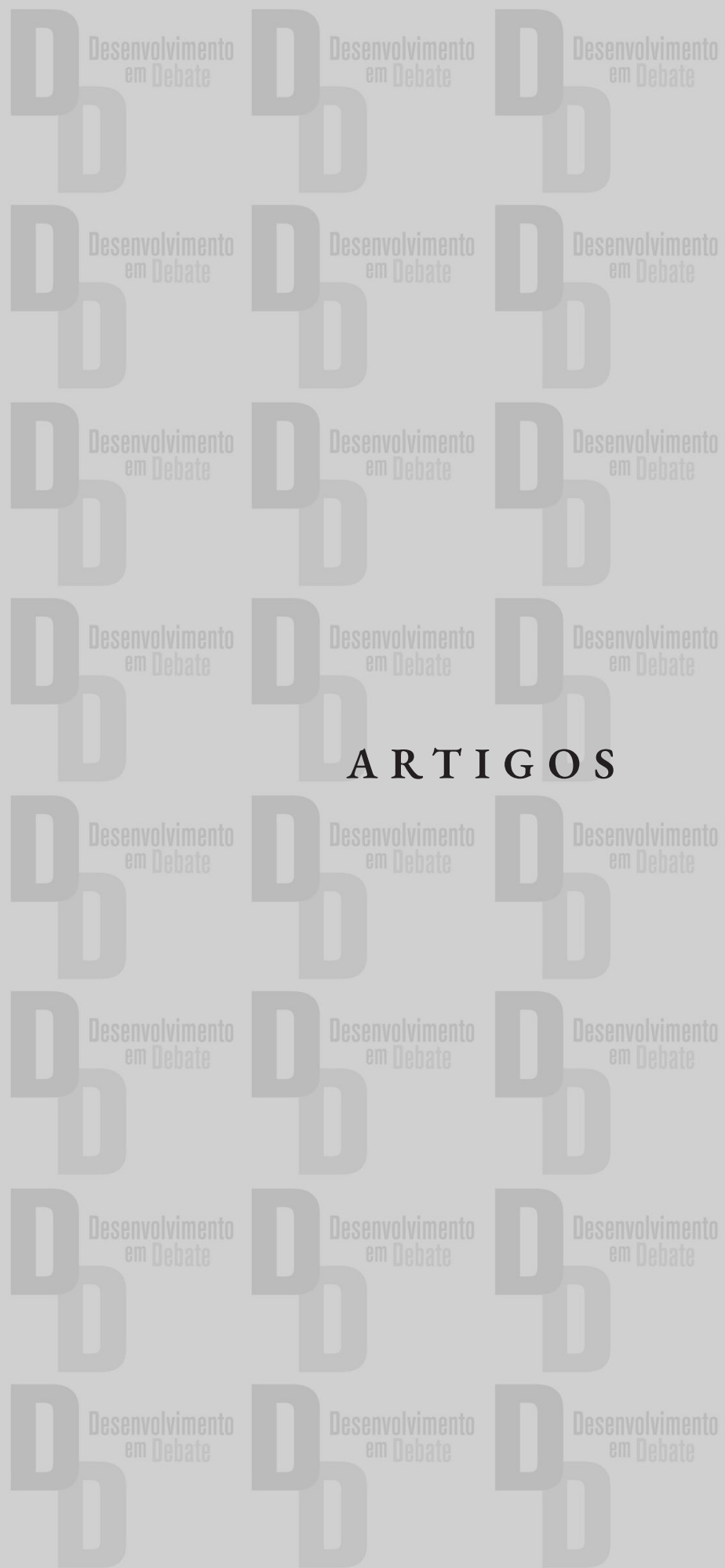
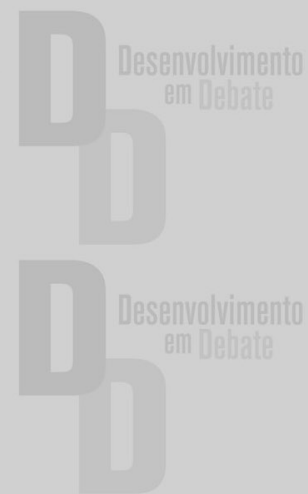
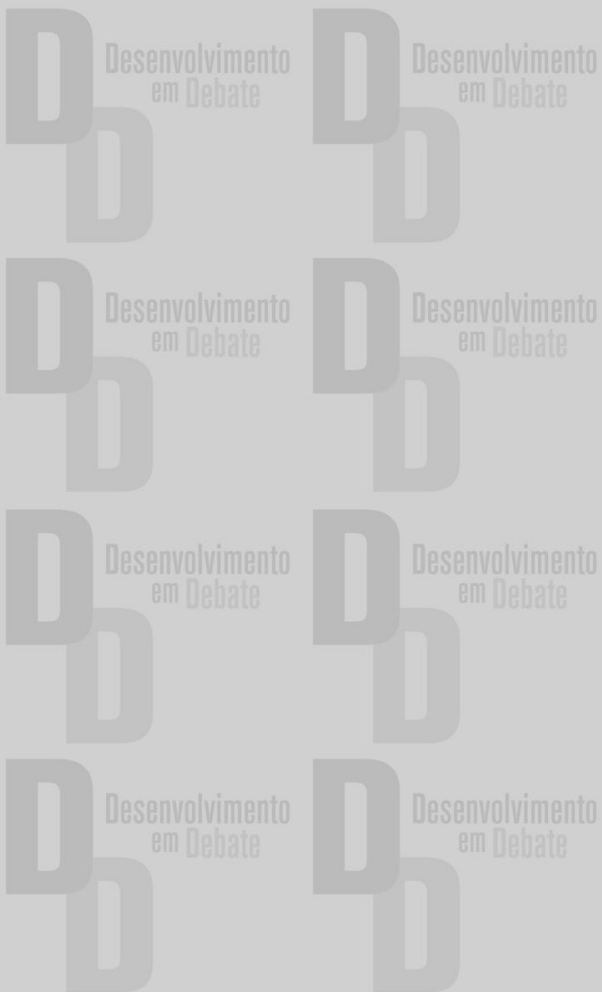

Desenvolvimento enn Debale 



\title{
Desenvolvimento e inserção externa da América Latina: a autonomia periférica e o legado de Hélio Jaguaribe
}

\author{
Development and External Insertion of Latin \\ America: Peripheral Autonomy and the Legacy \\ of Hélio Jaguaribe
}

\author{
Leonardo Granato* | Katiele Rezer Menger**
}

\begin{abstract}
Resumo
Na segunda metade do século XX surgiram, na América Latina, relevantes contribuições no âmbito do pensamento social, político e econômico para pensar o desenvolvimento e inserção externa dos países do continente. Uma das correntes que ganharam destaque foi a da autonomia latinoamericana, cujo arcabouço teórico-conceitual ainda demonstra significativo potencial para a análise da política latino-americana. Através de uma pesquisa bibliográfica, o presente trabalho propõe uma discussão sobre a contribuição de Hélio Jaguaribe ao debate sobre autonomia periférica, assim como sobre a vigência da referida contribuição.
\end{abstract}

Palavras-chave: Estado Periférico; Autonomia; Desenvolvimento; Inserção Externa; Hélio Jaguaribe.

\begin{abstract}
In the second half of the twentieth century, relevant contributions emerged in Latin America in the sphere of social, political and economic thinking to discuss the development and external insertion of the countries of the continent. One of the currents that gained prominence was Latin American autonomy, whose theoretical-conceptual framework still shows significant potential for the analysis of Latin American politics. Through a bibliographic research, this paper proposes a discussion about the contribution of Hélio Jaguaribe to the debate about peripheral autonomy, as well as the validity of this contribution.
\end{abstract}

Keywords: Peripheral State; Autonomy; Development; External Insertion; Hélio Jaguaribe.

\footnotetext{
* Professor do Programa de Pós-Graduação em Ciência Política da Universidade Federal do Rio Grande do Sul (UFRGS), RG, Brasil. Coordenador do Núcleo de Estudos em Política, Estado e Capitalismo na América Latina (NEPEC-UFRGS). https://orcid.org/0000-0002-0337-7220. E-mail: granato.leonardo@gmail.com

** Mestranda, com bolsa da CAPES, do Programa de Pós-Graduação em Ciência Política da UFRGS e pesquisadora do NEPEC-UFRGS, RG, Brasil. https://orcid.org/0000-0001-7332-1989. E-mail: katiele.menger@gmail.com
} 


\section{INTRODUÇÃO}

$\mathrm{Na}$ segunda metade do século XX surgiram, na América Latina, relevantes contribuiçóesno âmbito do pensamento social, político e econômico para pensar o desenvolvimento e inserção externa ${ }^{1}$ dos países do continente, numa perspectiva própria, autóctone. As condiçóes e possibilidades para conduzir suas políticas econômicas e externas de modo autônomo, ou seja, em resposta a seus interesses nacionais e livre dos constrangimentos impostos pela hegemonia dos países centrais, constituíram o centro de uma prolífica produção intelectual nos anos 70 e em parte dos anos 80. Ainda que a discussão já se mostrasse instalada desde a década de 50, por meio dos estudos da Comissão Econômica para América Latina e o Caribe (CEPAL) no âmbito da Economia Política, foram esses os anos que se caracterizaram por um debate voltado para a autonomia enquanto conceito político (de modo a diferenciá-lo de soberania como conceito jurídico $)^{2}$, conjuntamente com um intenso ativismo de formuladores de política externa ${ }^{3}$.

Particularmente no contexto sul-americano ${ }^{4}$, sobretudo a partir do pósSegunda Guerra, as reflexóes sobre autonomia estiveram motivadas pela finalidade de desarticular, ou pelo menos colocar em discussão, aqueles princípios da teoria realista clássica de Relações Internacionais que atribuíam aos países mais frágeis a posição de unidades "dependentes” no sistema internacional. Já no âmbito da Economia Política, a perspectiva da autonomia também contribuiria com a reflexão mais ampla sobre desenvolvimento econômico latino-americano ao questionar uma divisão internacional do trabalho cuja estrutura assegura a transferência de capitais e mais-valia das regióes periféricas ao centro dosistema mundial.

Tal como expressou Colacrai (2009), ainda que possamos encontrar no contexto cepalino as bases originárias de uma teoria da autonomia, tais postulaçôes não constituem uma mera revisão histórica, visto que grande parte das discussões que aí se estabeleciam ainda não foram esgotadas, e continuam a pautar, desafiantes, o debate sobre desenvolvimento e inserção externa da América Latina. Dentre os teóricos dessa corrente da autonomia encontra-se Hélio Jaguaribe, protagonista de uma reflexão orientada a identificar correlaçôes entre o desenvolvimento e os modelos políticos capazes de desencadeá-lo ou de intensificá-lo. É a partir do referido marco que o autor desenvolve o conceito de autonomia, como contraponto ao de dependência. Segundo Jaguaribe (1973, p. 4), essa noção de autonomia se referiria ao processo de tomada de decisão que diz respeito às políticas de desenvolvimento. Dessa forma, um desenvolvimento de tipo "autônomo" consistiria em processos cujas decisóes relevantes seriam tomadas por agências latino-americanas, conforme as suas próprias perspectivas, interesses e demandas ${ }^{5}$. 
O presente trabalho tem, assim, como objetivo principal retomar e discutir asprincipais categorias da contribuição de Jaguaribe ao debate da autonomia latino-americana ${ }^{6}$. A retomada dos preceitos da chamada "Escola da Autonomia" é de grande importância pois esta se baseia na construção original de um conceito próprio dos países periféricos, no duplo sentido de discutir as possibilidades de os países tomarem as decisóes por si, e de relacionar isso com a importância de não somente replicar os modelos do centro para a análise das estratégias de desenvolvimento e inserção externa. Ademais, o resgate do trabalho de Jaguaribe aqui proposto visa, também, a servir como aporte teórico para discussões futuras sobre as condições de uma inserção externa não subordinada dos Estados latino-americanos no sistema mundial.

O presente artigo divide-se, então, em duas partes, além de uma conclusão. Na primeira parte, busca-se apresentar e discutir o conceito de autonomia de Jaguaribe, ressaltando a contribuição do referido autor para o debate sobre desenvolvimento e inserção externa, a partir de uma pesquisa bibliográfica. $\mathrm{Na}$ segunda parte, propóe-se uma discussão sobre a atualidade do conceito de autonomia, suas possibilidades de utilização e de aprofundamento na contemporaneidade.

\section{A NOÇÃO DE AUTONOMIA NO PENSAMENTO DE JAGUARIBE}

Como já expresso na introdução deste trabalho, a perspectiva da autonomia desenvolvida por Jaguaribe representa um valioso legado da obra do autor para pensar as estratégias de desenvolvimento capitalista e inserção externa na periferia da geopolítica mundial. Assim como Juan Carlos Puig na Argentina ${ }^{7}$, com base nos estudos precedentes da $\mathrm{CEPAL}^{8}$, e como contraponto às teorias da dependência ${ }^{9}$, Jaguaribe desenvolveu um conjunto de reflexốes e análises sobre a situação latino-americana no sistema internacional e as margens de autonomia que esse sistema oferecia para o desenvolvimento ${ }^{10}$ desses países. Em sua obra, o autor apontava, também, a necessidade de ponderar o contexto regional, pela via da integração regional, como parte da estratégia que deveria ser levada adiante pelos Estados latino-americanos para combater a percepção da ordem mundial como submetida a uma dinâmica incontrolável, de efeitos inexoráveis, para lutar, em definitivo, contra um suposto estado de "periferismo" permanente (FURTADO, 1968; JAGUARIBE,1973).

Para Jaguaribe, em termos de desenvolvimento e inserção externa, "a seleção objetiva do modelo mais adequado para um país requer [...] uma análise preliminar histórico-estrutural do país em questão, a fim de se poder determinar objetivamente seus principais traços e tendências estruturais” 
(JAGUARIBE, 1973, p. 85). O autor formulou, assim, suas discussões teóricas em torno do conceito de autonomia a partir da análise dos problemas estruturais que, a seu entender, acometiam a América Latina desde o fim da década de 50, dentre os quais destacam-se o estancamento econômico, político, social e cultural da região; o status marginal frente aos países mais desenvolvidos do centro; a desnacionalização dos setores estratégicos da economia; a desnacionalização cultural (mediante o estabelecimento de uma dependência científico-tecnológica com caráter crescente e cumulativo com relação aos países mais avançados); a desnacionalização político-militar (mediante o crescente controle dos países latino-americanos, efetuados por dispositivos político-militares cuja concepção de mundo e interesses corporativos se baseavam em uma liderança hegemônica dos Estados Unidos).

Fica assim retratado como os referidos problemas, bem como os "modelos" de desenvolvimento e inserção externa (associados à potência hegemônica ou pretensamente "autônomos") perante eles adotados, que constituíram os traços marcantes das relaçóes externas latino-americanas (JAGUARIBE, 1973; FERRER, 2006), remetem ao papel "homogeneizador" dos Estados Unidos na região. Durante o período da Guerra Fria, uma falsa "homogeneização regional” foi efetuada pela potência hemisférica através do Tratado Interamericano de Assistência Recíproca (e suas respectivas instituições de difusão da Doutrina de Segurança Nacional), da forte presença de empresas multinacionais, e da própria Organização de Estados Americanos, cuja função sempre foi sobretudo política e cuja agenda refletia majoritariamente os interesses norte-americanos (KAPLAN, 1968; O'DONNELL \& LINCK, 1973; LIMA, 2013).

A formulação jaguaribeana da ideia de autonomia parte, então, de um reconhecimento dos constrangimentos e vulnerabilidades advindos da estrutura, e avança ao fazer parte de um objetivo maior, que é ser o alicerce para um modelo factível de desenvolvimento na periferia, dentro do marco do sistema interestatal capitalista, e das formas de acumulação nele estabelecidas. Segundo o autor, "como modelo representacional, o modelo da autonomia expressa uma situação e um processo de desenvolvimento social caracterizado, no caso da América Latina, pela combinação, em um aspecto, do desenvolvimento [...] dos países latino-americanos como sociedades nacionais em termos autônomos e, em outro aspecto, pela integração dessas naçóes” (JAGUARIBE, 1973, p. 65, tradução nossa).

Dentre os argumentos centrais das formulaçốes de Jaguaribe, ainda no plano dosconstrangimentos e vulnerabilidades externos, encontra-se a ideia da existência de uma ordem internacional estratificada, na qual há quatro níveis com decrescente capacidade de autodeterminação ou autonomia deci- 
sória (JAGUARIBE, 1979; LORENZINI, 2014). O nível mais alto seria o da primazia geral, correspondente à combinação da inexpugnabilidade ${ }^{11}$ do território com o exercício de uma preponderância mundial generalizada esta última não só caracterizada por supremacia militar, mas também por um domínio em todos os planos da realidade social, do econômico ao cultural.

O nível subsequente seria o da primazia regional, que também corresponde à inexpugnabilidade do território combinada com o exercício de hegemonia sobredeterminadas áreas e uma presença considerável em outras, ainda que restrita globalmente. Já o terceiro nível seria o da autonomia, ao qual tem acesso os países que lograram superar sua dependência prévia, e contam com ampla margem de autodeterminação na conduçãode seus negócios internos, além de apreciável capacidade de atuação internacional independente - essa autonomia geral, segundo o autor, ainda se divide em dois tipos: uma regional e uma setorial.

A autonomia regional corresponde àquela autonomia exercida sobre uma determinada área geográfica. Por sua vez, a autonomia setorial diz respeito à autonomia exercida sobre um setor das capacidades estatais, notadamente da dimensão econômica. Ainda que não disponham de meios para assegurar a inexpugnabilidade de seu território, tais países teriamcondições de impor severas penalidades, materiais e morais, a um eventual agressor.

Por fim, há ainda o último nível, onde se encontram a maior parte dos países, que seria o da dependência. Em tal nível estariam todos os países que, apesar da condição nominal de Estados soberanos, dependem das decisóes e de fatores externos os quais emanam de países dotados de primazia geral ou regional, ou até mesmo de países autônomos.

A partir desses postulados, o autor completa seu raciocínio mediante a formulação de dois grandes eixos de análise simultânea para o estudo da inserção internacional de um país: um mais estático e estrutural, a partir do qual são analisados os fatores materiais correntes disponíveis ao país; e outro dinâmico e funcional, a partir do qual são analisadasas possibilidades de transformação da posição relativa de um país no sistema internacional (JAGUARIBE, 1979; 1973; 1962).

Assim, em termos estruturais, o acesso à autonomia depende, segundo Jaguaribe, de duas condiçôes básicas: a viabilidade nacional e a permissibilidade internacional. A viabilidade nacional de um país depende, para um determinado momento histórico, da disponibilidade de recursos humanos e naturais, incluindo-se a capacidade de intercâmbio internacional. Quanto mais exigentes as condiçôes gerais de uma época, especialmente no que se refere às tecnologias e às escalas mínimas de operacionalidade derivadas dessa tecnologia, maiores serão as massas mínimas de recursos humanos e 
naturais necessários, bem como suas características qualitativas (JAGUARIBE, 1979).

Já a categoria de permissibilidade, por sua vez, refere-se, conforme o autor, às condições de país no tocante à neutralização do risco proveniente de outros países, dotados de meios eficientes para exercer formas eficazes de coerção. Essa categoria leva em consideração a situação geopolítica e as relações internacionais do país em questão, que podem ser internas, como o fortalecimento de capacidades econômico-militares, ou externas, como o estabelecimento de alianças defensivas (JAGUARIBE, 1979).

A partir dessa tipificação, Jaguaribe aponta três alternativas para o desenvolvimento na América Latina, quais sejam: dependência, revolução e autonomia. A primeira seria a maisestável e tendencial, pois implica uma predominância de um dos polos do conflito. A segunda alternativa conduz a formas instáveis de predomínio de uma tendência, dado seu caráter disruptivo. A terceira, então, trataria da busca pela estabilidade pela via da autonomia (JAGUARIBE, 1973). Dentre suas reflexôes sobre as três opçóes, Jaguaribe aponta que a opção autonomista, no longo prazo histórico em que se originam as modificaçóes macroestruturais, seria a mais adequada.

Ainda que a conquista de um destino próprio pela América Latina enfrente pressóes externas opostas ao projeto de desenvolvimento autônomo, bem como pressôes internas das próprias elites políticas e econômicas que se beneficiam da inserção dependente dos seus Estados, descartadas as alternativas de dependência e de revolução, a América Latina deveria, para Jaguaribe, alcançar relativa estabilidade pela via da autonomia. Assumindo a premissa de que existiria, nos países do continente, o compromisso de pretensas burguesias nacionais com projetos autonomistas, Jaguaribe idealizou o chamado "modelo autônomo de desenvolvimento e integração da América Latina", que articularia o conceito de autonomia com os conceitos de desenvolvimento e integração regional, entendida essa última como uma ferramenta dos projetos autonomistas na periferia global (JAGUARIBE, 1973).

Conforme expresso pelo autor, o referido modelo autônomo se orienta em direção a uma integração socioeconômica das naçốes do continente, essencialmente em proveito de cada um desses Estados em particular, e do sistema regional em geral (JAGUARIBE, 1973, p. 68). Além disso, o autor também esclarece que este modelo se baseia, por um lado, na formação de um grande fundo de recursos humanos, tecnológicos, naturais e financeiros, que permitam à região alcançar, em grande escala e com elevada produtividade, os níveis mais avançados de industrialização e os correspondentes níveis de desenvolvimento cultural, social e político; e, por outro lado, na formação de um grande mercado, para a produção da própria região, que favoreça o 
desenvolvimento autossustentado. Porém, ao questionar-se a noção de Estado que subjaz ao raciocínio do autor, parece aplicar-se a esse a crítica que Fiori faz à modernização industrializante da CEPAL: por trás de seus planos jaz a "crença inabalável na existência de um Estado racional, homogêneo e funcional, capaz de formular políticas de crescimento econômico, por cima de divisóes, conflitos e contradiçóes que pudessem atravessar e paralisar o próprio Estado" (FIORI, 2013, p. 4).

Por fim, e finalizando com a discussão do modelo proposto pelo autor, cabe ressaltar que como tal modelo da autonomia proporciona aos países da região condiçốes internas tanto de autonomia em suas decisôes, quanto de desenvolvimento endógeno, assegura-se, também, a capacidade independente de segurança nacional, tanto interna quanto externamente, que seria expressa, segundo Jaguaribe, em um sistema independente de segurança regional controlado pelos próprios países latino-americanos. Jaguaribe deixa aqui, assim, assentada uma relevante contribuição de caráter multidimensional ou multifacetada (incluindo, como visto, aspectos económico-políticos e de defesa, principalmente) para refletir sobre o papel da integração regional como estratégia de mobilização e do compartilhamento dos recursos de poder nacionais em prol do fortalecimento das capacidades estatais em cada formação social ${ }^{12}$. Discutida noção de autonomia na obra jaguaribeana, na próxima seção, debatem-se as suas possibilidades de utilização e de aprofundamento na contemporaneidade.

\section{A AUTONOMIA COMO CATEGORIA CONTEMPORÂNEA DE ANÁLISE}

Ressaltar a atualidade da noção de autonomia periférica, em contraposição àqueles que alegam que essa perspectiva teria ficado ultrapassada depois do fim da Guerra Fria, demanda uma retomada da configuração do sistema mundial no período pós-Guerra Fria e de suas transformaçóes, possibilitando, assim, uma discussão acerca das assimetrias e desigualdades que caracterizam o atual tabuleiro mundial. Após alguns apontamentos aesse respeito, buscamos ressaltar a contribuição do conceito em pauta para pensar as estratégias de desenvolvimento e inserção externa da América Latina.

Há profundas transformaçôes geopolíticas e geoeconômicas no sistema internacional ensejadas no período final da Guerra Fria que moldam a configuração da ordem mundial atual. $\mathrm{O}$ modelo capitalista fordista-keynesiano entra em crise quando a divisão internacional do trabalho deixa de corresponder às demandas do padrão de consumo e de produção vigente até o começo da década de 70 , visto que a rigidez do modelo inviabilizou a 
sequência do crescimento, dada a tendência ao declínio da taxa de lucros que começa a se acentuar, e, de forma geral, diante das contradiçóes inerentes do capitalismo (HARVEY, 1989). Em 1971, o fim da conversibilidade dólar-ouro faz com que a moeda norte americana seja o dinheiro hegemônico nas reservas mundiais, bem como a referência de todo o sistema financeiro mundial (DAVIS, 1985) ${ }^{13}$.

A intensificação do apoio soviético às revoluçóes na periferia do chamado Terceiro Mundo, bem como os tensionamentos no Oriente Médio, representam uma inflexão naação dos Estados Unidos no sistema internacional, que se orienta cada vez mais como uma presença mais direta e ofensiva ao invés de presença indireta por meio de aliados confiáveis (JAGUARIBE, 1982). A ascensão de ideais políticos e econômicos conservadores e a retomada do modelo neoliberal, na década de 80 , convergem com novas movimentaçóes dos Estados Unidos visando a conter os governos socialistas, o que inaugura uma nova corrida armamentista com supremacia norte-americana em relação à Rússia (VISENTINI, 1999b). O fim do mundo bipolar, com a dissolução da União Soviética, em 1991, ainda que compreendido pelo Ocidente como a vitória da liberdade e da democracia capitalistas frente à ameaça comunista, veio acompanhado da fragilizaçãoda hegemonia norte-americana, cujos sinais de declínio já são apontados por muitos autores desde a década de 1970, sendo 1991, possivelmente, o marco do fim da PaxAmericana, uma vez que a instável ordem multipolar emergente impóe inúmeros desafios aaté então "supremacia estadunidense"

Dentre as transformaçóes geopolíticas e geoeconômicas legadas pela Guerra Fria há quedestacar a predominância do modelo neoliberal, somada à concomitante dependência dos Estados Unidos em relação ao resto do mundo, uma vez que esse país, desde os anos 70, apresenta um déficit comercial estrutural, tendo seu equilíbrio econômico ficadototalmente dependente de fluxos de capitais externos. $\mathrm{Na}$ esteira da consolidação do neoliberalismo e de suas instituiçôes internacionais legitimadoras (cujo maior patrocinador são os próprios Estados Unidos), o conceito de globalização toma conta das análises internacionais a partir da década de 90 . Longe de generalizaçóes, a globalização ${ }^{15}$ deve ser compreendida não como um processo de curto prazo, ou correspondente a uma fasedeterminada do capitalismo, mas teria como definição mais precisa um processo contínuo de interação, conflito e integração, de longa duração, em que há simultaneamente rompimento e estreitamento de laços (AMIN, 1997) ${ }^{16}$.

A paulatina, mas constante, redução do poder relativo Estados Unidos, não impede este país de disputar o controle de recursos mundiais e de empreender uma corrida armamentista num eterno movimento de estar à frente 
das demais potências e de ser capaz de ainda ditar o regime de segurança internacional. Todavia, a geopolítica do sistema internacional pós-Guerra Fria conta com a consolidação de polos de poder que não podem ser ignorados, como a Europa, o Japão, a Rússia e, mais recentemente, a China (VISENTINI, 2019). No tocante aos dois últimos, estes seriam as outras duas grandes potências capazes de desafiar os Estados Unidos. Ainda que não possam impor uma ordem ao resto do mundo, ao menos detêm capacidades suficientes para garantir sua soberania estratégica, figurando na categoria de Jaguaribe de primazia regional.

$\mathrm{Na}$ América Latina, o fim da década de 80 culmina no processo de redemocratização do continente e da paulatina substituição da estratégia desenvolvimentista pelo modelo neoliberal, guiado pelos interesses do mercado ${ }^{17}$. Nesse período houve, também, umamudança de ótica sobre a integração regional, entrando em cena o "regionalismo aberto", pautado pelo objetivo de reforçar os processos de reforma estrutural dos mercados domésticos, "unificar" os processos políticos internos sob o princípio liberal-democrático,e favorecer a inserção das economias latino-americanas nas cadeias globais de valor, (GRANATO \& REBOUÇAS, 2017). Esse modelo de integração "satelizante" 18 só viria a mudar nos anos 2000, quando as políticas externas do Brasil e da Argentina marcaram os projetos de desenvolvimento dos respectivos países com o selo da autonomia, em diálogo com os outros governos progressistas da América do Sul (GRANATO, 2015). Nesse contexto, cabe afirmar junto com Briceño-Ruiz a vigência do debate sobre autonomia "ao se converter [a autonomia] em uma das variáveis para compreender o regionalismo latino-americano, sua continuidade e resiliência. Este encarna uma agenda de pesquisa que ainda tem muitos aspectos por desenvolver” (BRICEÑO-RUIZ, 2014, p. 38, tradução nossa) ${ }^{19}$.

Por outra parte, e retomando a questão do cenário externo, a emergência de novos eixos de poder mundial que começam a despontar frente à hegemonia norte-americana não elimina a natureza hierárquica e competitiva da ordem política e econômica internacional que, como afirma Fiori (1999), é um impasse ao desenvolvimento autônomo com inclusão social, sobretudo dadas as coalizóes de poder que asseguram o aparato estatal, as quais garantem a perpetuação dos interesses da classe capitalista ${ }^{20}$. A partir desse entendimento, parece pertinente refletir acerca de como a perspectiva da autonomia chama a atenção para a relevância de pensar os programas de ação nacionais enquanto expressão dos planos de desenvolvimento e de inserção internacional dos Estados latino-americanos e, portanto, entendê-los como processos sociais que não podem ser explicados apenas por oportunidades ou restrições sistêmicas. 
Atualmente, segue se entendendo por autonomia a capacidade de executar uma agenda própria de políticas para o desenvolvimento, somada a uma maior margem de negociação eproposição frente ao núcleo orgânico do capitalismo (BERNAL-MEZA, 2015). Assim, em meio a atual cenário global, diferente daquele em que a perspectiva autonomista foi originalmente concebida, a pertinência da conceituação formulada por Jaguaribe emerge claramente, pois, "diferentemente das palavras [...], os conceitos são ferramentas epistêmicas que não necessariamente precisam se ajustar aos acontecimentos, mas que são construídos para permitir uma aproximação aos mesmos com o objetivo de compreendê-los, explicá-los e, eventualmente, operar sobre eles" (SAINT-PIERRE, 2011, p. 409). Em igual sentido, para Saraiva (2014), a autonomia em Jaguaribe não é um dado estável ou progressivo, e pode até parecer uma estrutura, mas não é estática. Como afirmao autor, mudam-se as circunstâncias, mas a capacidade de agir sobre o mundo e deresponder aos estímulos sistêmicos e demandas internas exige um quadro conceitual e lógico das possibilidades e alternativas da América Latina que o aporte teórico de Jaguaribe consegue alcançar. 
A capacidade operativa e explicativa das categorias analíticas desenvolvidas por Jaguaribe em torno da ideia de autonomia nos conduz a refletir que, no contexto atual, caberia aos países latino-americanos -a partir de suas posiçốes periféricas ou semiperiféricas- empreender iniciativas que visem a reduzir a distância que os separa dos países centrais, na tentativa de reduzir os impactos regressivos de um sistema internacionaldesigual, articulado por aqueles que exercem as posições dominantes de poder. Em outras palavras, o desafio dos Estados latino-americanos de buscar que seu espaço na divisão internacional do trabalho lhes permita avanços em sua industrialização, geração de conhecimento e tecnologia, e uma redução dos níveis de desigualdade internos, continua a se traduzir, também, na busca de estratégias para uma inserção não subordinada no sistemainternacional.

\section{À GUISA DE CONCLUSÃO}

Conforme expresso na introdução ao presente trabalho, buscou-se aqui resgatar e discutir a contribuição de Jaguaribe ao debate sobre a autonomia latino-americana, no contexto dos desafios impostos pelo desenvolvimento nacional e por novas formas de articulação e integração entre os países do continente que, sobre a base da reciprocidade e o reconhecimento das assimetrias do desenvolvimento, fortaleçam a interdependência na região e promovam uma inserção soberana conjunta no sistema internacional. Como teórico de um país periférico, Jaguaribe defendia a importância de pensar as políticas parao desenvolvimento capitalista a partir de uma postura própria, reconhecedora da realidade nacional e regional, de seu entorno e constrangimentos.

É preciso ter em mente a relevância que, no pensamento multifacetado do autor, a buscada autonomia no continente tem como condição o desenvolvimento da própria região periférica. A questão da autonomia, diretamente vinculada à questão do desenvolvimento, é aquela dos que questionam a permanência na periferia, ainda que sem aboli-la, dosistema internacional. A política externa autônoma apresenta-se, assim, no esquema de pensamento em pauta, como possível ferramenta dos Estados periféricos latino-americanospara ampliar a sua margem de atuação internacional, contribuindo tanto para a obtenção de insumos para a política de desenvolvimento nacional, como, também, para incidir nas estruturas do sistema internacional que governam diferentes áreas das políticas públicas internacionais, e que determinam esquemas de relacionamentos favoráveis aos países centrais em prejuízo dos periféricos. 
Conforme ficou retratado neste trabalho, a noção de autonomia firma o entendimento deque o estudo da estrutura do sistema internacional permite compreender os condicionantes da inserção internacional, o que, por sua vez, é de grande auxílio na compreensão da própria realidade e, assim, da elaboração de um projeto de desenvolvimento nacional e inserção não subalterna, desafiador dos constrangimentos e limitantes do sistema. Ou seja, apesar da centralidade de se empreender uma análise sistêmica em um estudo de política externa, não se pode ter como pressuposto que o regime internacional vigente é um determinante per se da inserção internacional dos países periféricos, pois a ordem internacional é estratificada, mas não necessariamente estática. Logo, trazer perspectivas sobre uma realidade dinâmica é algo que não se encerra em si, mas exige a contínua adequação do modelo às singularidades do caso em análise e aos atuais desafios impostos pelo capitalismo neoliberal.

Por fim, cabe ressaltar que as reflexóes de Jaguaribe também nos legam um ponto de partida crucial quando se pensa a inserção internacional no sistema interestatal capitalista: não há um único caminho para a autonomia, tampouco há um modelo mais viável para alcançá-la. O que, contudo, não significa que não se possa identificar as variáveis que venham a contribuir com uma possível inserção internacional autônoma e formular possíveis estratégias para alcançá-la.

\footnotetext{
Notas

1 Note-se que se fala de "desenvolvimento e inserção externa", e não de desenvolvimento e de inserção externa, no sentido de enfatizar a importância de ambos os dois andar lado a lado, se complementando e retroalimentando.

${ }^{2}$ A palavra "autonomia", do ponto de vista etimológico, tem origem grega, formada pelo adjetivo "autos", que significa "de si mesmo", "por si mesmo", "espontaneamente", e pela palavra "nomos" que significa "uso", "lei", "convenção". Etimologicamente, portanto, autonomia significa "dar-se nas suas próprias leis" e implica propriedade constitutiva da pessoa humana, na medida em que the cabe escolher as suas normas e valores, fazer projetos, tomar decisões e agir em consequência dessas escolhas (CUNHA, 2007, p. 84). Dito isto, importa esclarecer também que o conceito de autonomia neste trabalho é de caráter essencialmente "político", advindo da reflexão política, e faz alusão ao Estado enfrentando "por si mesmo" os constrangimentos externos, decorrentes das relações do sistema interestatal capitalista, e reforçando suas capacidades de ação no plano interno.

${ }^{3}$ A busca pela autonomia foi um objetivo central que orientou a ação externa da maioria dos Estados latino-americanos até os anos 80, que cresceu de maneira proporcional ao aumento da hegemonia norte-americana na região. No caso brasileiro, é consenso na literatura especializada que o conceito de autonomia contribui para explicar diversos momentos da política externa do país (MOURA, 1980; CERVO, 2008; CERVO \& BUENO, 2011; LIMA, 1992; PINHEIRO, 2000; GUIMARÃES, 1999; SARTI, 2017; VIGEVANI \& CEPALUNI, 2011; VISENTINI, 1999a; 2003).

${ }^{4}$ A questão da autonomia constituiu um assunto mais sul-americano do que latino-americano. No México, na América Central e no Caribe, a ênfase era posta sobre a soberania, devido ao fato de que esta região foi, historicamente, objeto de diversas ações coercitivas e de força por parte dos Estados Unidos. Por sua vez, a América do Sul dispunha de uma certa margem de manobra diplomática, comercial e cultural relativamente maior frente a Washington. Para mais informações, ver Bandeira (2010).
} 
${ }^{5}$ Em igual sentido, veja-se Puig (1980).

${ }^{6}$ Salienta-se que o presente texto se trata de uma publicação intermediária de um projeto de pesquisa mais amplo, intitulado "O Estado no pensamento social latino-americano: Perspectivas clássicas e contemporâneas" (UFRGS-CNPq), sob coordenação do Prof. Leonardo Granato. O referido projeto se propõeefetuar um balanço bibliográfico a respeito das contribuições de autores latino-americanos que se debruçaramsobre a natureza e significado do Estado capitalista periférico, assim como sobre as relações de conflito e os constrangimentos que o permeiam, interna e externamente, no seu acionar.

${ }^{7}$ No tocante ao desenvolvimento de categorias analíticas para conceituar autonomia, cabe mencionar a obra de Juan Carlos Puig, teórico argentino com quem Jaguaribe protagonizou o debate da autonomia latino-americana (PUIG, 1980; 1984). Ainda que ambos os autores utilizassem nomenclaturas distintas para descrever os regimes internacionais no marco da Guerra Fria, a questão da assimetria de poder no sistema e das possibilidades de buscar autonomia são centrais em ambas as análises. Para ampliar, ver Bologna (1987); Colacrai (2009); Simonoff (2014); Granato (2014); Muñoz (2016); Briceño-Ruiz \& Simonoff (2017), e Gullo(2018).

${ }^{8}$ É expressiva a influência da CEPAL no trabalho de Jaguaribe e na formulação de seus postulados, sabida sua conexão com a corrente desenvolvimentista herdeira de Roberto Simonsen (TOLEDO, 2004) e, também, sua atuação no ISEB (Instituto Superior de Estudos Brasileiros, criado por decreto do governo de Café Filho, em 1955), espaço esse onde o autor avançaria na ideia do desenvolvimento como vetor de uma política externa autônoma no sistema capitalista (GRANATO, 2014).

${ }^{9}$ Para mais informações, veja-se Treacy (2018).

${ }^{10} \mathrm{Com}$ o termo "desenvolvimento", Jaguaribe (1968) faz referência a um processo histórico-social global, no contexto da racionalidade e pragmática modernos aplicados à organização da vida social, e que abrange dimensões como a econômica, a social, a cultural e a política. Distinguindo, assim, desenvolvimento de crescimento econômico, para o autor em pauta, na discussão sobre desenvolvimento não se pode levar a autonomia de algum dos aspectos em que se desdobra o referido processo histórico-social (por exemplo, o econômico) ao ponto de se considerar como desvinculado deste.

11 Jaguaribe (2005) aponta que, no período posterior à Segunda Guerra, os Estados Unidos passaram a lograr de uma posição de superpotência, caracterizada pela combinação da inexpugnabilidade do território próprio assegurada pela detenção de uma devastadora capacidade nuclear de contra-ataque, capacidade de second strike, que consiste no fato de o potencial balístico-nuclear e os mecanismos de respostas automáticas de que dispõe serem de tal sorte que, mesmo no caso de sofrer um devastador ataque nuclear, esta continuará com capacidade suficiente para destruir completamente qualquer possível agressor. Segundo Cepik (2013), a inexpugnabilidade se caracteriza pela posse e modo de emprego de capacidades convencionais que impossibilitam a sustentação de invasão e conquista territorial por qualquer outro Estado no sistema internacional. Essas reflexões apontam para a compreensão de que não há uma estabilidade de longo prazo na posição que as nações ocupam no sistema internacional, sendo a própria inexpugnabilidade um conceito que não é estanque, pois depende das interações entre os atores. Do mesmo modo seria a capacidade de projeção de um país, sempre avaliada ex ante interação conflituosa.

12 Premissas essas que à época da reflexão de Jaguaribe, também eram discutidas por O'Donnell na Argentina, em O'Donnell \& Linck (1973). No âmbito brasileiro, é evidente o quanto sua obra dialoga com teóricos como Gerson Moura, para quem a política externa de um país dependente estaria condicionada simultaneamente ao sistema de poder em que se situa, bem como às conjunturas políticas, interna e externa (MOURA, 1980). Segundo o referido autor, isso acentua a necessidade de conjugar as determinações estruturais, as quais delimitam o campo de ação dos agentes decisores, com as determinações conjunturais, dadas pela decisão e ação dos policy makers. Moura (1980) explicita que a análise de política externa empreendida a partir da conjugação da estrutura e da conjuntura serviria a dois propósitos: repelir a noção de que a política externa de um país dependente é um simples reflexo das decisões do centro hegemônico, e negar que se possa entendê-la mediante somente o exame das decisões tomadas no país subordinado.

${ }^{13}$ Para mais informações, veja-se Calvocoressi (2011).

${ }^{14}$ Ver o estudo de Buzan \& Little (2000).

${ }^{15} \mathrm{Ou}$, nos termos de Chesnais (1996), a "mundialização do capital".

${ }^{16}$ Veja-se, também, Arrighi (1996).

${ }^{17}$ Para mais informações, ver Oliver-Costilla (1997). 


\begin{abstract}
${ }^{18}$ Foi esse o termo que Jaguaribe (1973) utilizou para qualificar um dos mais relevantes empreendimentos de integração da América Latina, a Associação Latino-Americana de Livre Comércio (ALALC), de 1960, em virtude da forte ingerência das empresas multinacionais no espaço integrado. Já no paradigma do regionalismo aberto que prevaleceu nos anos 90, tal termo parece se tornar novamente representativo de uma integração aberta aos mercados.

${ }^{19}$ Neste sentido, cabe ressaltar os estudos de Russell \& Tokatlian (2010; 2003), estudos esses que partem do pressuposto de que, no século XXI, a autonomia (adjetivada pelos autores de 'relacional') supõe a crescente interação, o trabalho coordenado, a negociação e ativa participação na elaboração de normas e regras internacionais, em regimes internacionais e principalmente na dimensão de integração regional, sendo o primeiro círculo, para o seu exercício, a própria região latino-americana. Em outros estudos, partindo-se dos postulados de Jaguaribe, a integração regional também é objeto de discussão enquanto instrumento de um Estado dotado de um projeto político autonomista (ODDONE \& GRANATO, 2009; GRANATO, 2015; GRANATO, ODDONE \& BATTAGLIA, 2016; GRANATO \& REBOUÇAS, 2018). Veja-se, também, Vigevani \& Ramanzini Jr. (2014).

${ }^{20}$ Cabe lembrar aqui a clássica afirmação de Braudel (1987, p. 55) acerca de que o capitalismo só triunfa quando se identifica com o Estado, quando ele é o Estado. Ver, também, Robinson (2015).
\end{abstract}

\section{Referências}

AMIN, S. Los desafíos de la mundialización. México: Siglo Veintiuno, 1997.

ARRIGHI, G. O longo século XX: dinheiro, poder e as origens de nosso tempo. Rio de Janeiro: Contraponto, 1996.

BANDEIRA, L. A. M. Brasil, Argentina e Estados Unidos: conflito e integração na América do Sul (da Tríplice Aliança ao Mercosul). Rio de Janeiro: Civilização Brasileira, 2010.

BERNAL-MEZA, Raúl. La doctrina de la autonomía: realismo y propósitos. Su vigencia. In: BRICEÑO-RUIZ, J. \& SIMONOFF, A. (Ed.). Integración Y cooperación regional en América Latina: Una relectura a partir de la teoría de la autonomía. Buenos Aires: Biblos, 2015. pp. 95-120.

BOLOGNA, A. B. Teorías y propuestas de relaciones internacionales para los países del sur. Cuadernos de Política Exterior Argentina, [s./v.], n. 1, pp. 1-39, 1987.

BRAUDEL, F. A dinâmica do capitalismo. Rio de Janeiro: Rocco, 1987.

BRICEÑO-RUIZ，J. Autonomía: genealogía y desarrollo de un concepto. Su relación con el regionalismo en América Latina. Cuadernos sobre Relaciones Internacionales,Regionalismo Y Desarrollo, v. 9, n. 18, pp. 9-41, 2014.
BRICEÑO-RUIZ, J. \& SIMONOFF, A. La Escuela de la Autonomía, América Latina y la Teoría de las Relaciones Internacionales. Estudios Internacionales, v. 49, n. 186, p. 3989, 2017.

BUZAN, B. \& LITTLE, R. International Systems in World History: Remaking the Study of International Relations. Oxford: Oxford University Press, 2000.

CALVO CORESSI, P. Política mundial a partir de 1945. Porto Alegre: Penso, 2011. CEPIK, M. Segurança internacional: $\mathrm{Da}$ ordem internacional aos desafios para a América do Sul e para a CELAC. In: SORIA, A. B. \& ECHANDI, I. A. (Org.) Desafíos estratégicos del regionalismo contemporáneo. CELAC e Iberoamérica. San José: FLACSO, 2013. pp. 307-324.

CERVO, A. Inserção internacional: Formação dos conceitos brasileiros. São Paulo:Saraiva, 2008.

CERVO, A. \& BUENO, C. História da política exterior do Brasil. Brasília: Editora UnB,2011.

CHESNAIS, F. A mundialização do capital. São Paulo: Xamã, 1996.

COLACRAI, M. Los aportes de la Teoría de la Autonomía, genuina contribución sudamericana. ¿La autonomía es hoy una cate- 
goría en desuso o se enfrenta al desafío de una renovación en un contexto interdependiente y más complejo? In: LECHINI, G.; KLAGSBRUNN, V. \& GONÇALVES, W. (Org.) Argentina e Brasil: Vencendo os preconceitos - As várias arestas de uma concepção estratégica. Rio de Janeiro: Revan, 2009, pp. 33-49.

CUNHA, A. G. Dicionário Etimológico da Língua Portuguesa. Rio de Janeiro: Lexikon Editora Digital, 2007.

DAVIS, M. O imperialismo nuclear e dissuasão extensiva. In: THOMPSON, E. et al. Exterminismo e Guerra Fria. São Paulo: Brasiliense, 1985. pp. 58-97.

FERRER, A. Hechos y ficciones de la globalización: Argentina y el Mercosur en el sistema internacional. Buenos Aires: Fondo de Cultura Económica, 2006.

FIORI, J. L. Estado e desenvolvimento na América Latina: Notas para um novo "programade pesquisa". Documento de Trabalho, n. 286. Brasília: CEPAL Escritório no Brasil, 2013. FIORI, J. L. Introdução: De volta à questão da riqueza de algumas nações. In: FIORI, J. L. (Org.) Estados e moedas no desenvolvimento das nações. Rio de Janeiro: Vozes, 1999. pp. 11-48.

FURTADO, C. Subdesenvolvimento e estagnação na América Latina. Rio de Janeiro: Civilização Brasileira, 1968.

GRANATO, L. A autonomia como vetor da ação externa e da integração na América do Sul: postulações teóricas. OIKOS - Revista de Economia Heterodoxa, v. 13, n. 2, pp. 7890, 2014.

GRANATO, L. Brasil, Argentina e os rumos da integração: o Mercosul e a Unasul. Curitiba: Appris, 2015.

GRANATO, L., ODDONE, N. \& BATTAGLIA, M. Teoría de la autonomía: ¿Aún vigente para analizar los procesos de cooperación e integración en América Latina? Teoria \& Pesquisa: Revista de Ciência Política, v. 25, n. 1, pp. 153-175, 2016.

GRANATO, L. \& REBOUÇAS, I. Estado, autonomia e integração regional na América
Latina. Latinoamérica: Revista de Estudios Latinoamericanos, [s./v.], n. 66, pp. 261-285, 2018.

GRANATO, L. \& REBOUÇAS, I. Heterogeneidade estrutural nas relações internacionais da América Latina: um olhar através dos paradigmas de integração regional. Cadernos PROLAM/USP, v. 16, n. 31, pp. 5-29, 2017.

GUIMARÃES, S. P. Quinhentos anos de periferia: Uma contribuição ao estudo da política internacional. Porto Alegre: EDUFRGS; Contraponto, 1999.

GULLO, M. Relaciones Internacionales. Una teoría crítica desde la periferia sudamericana. Buenos Aires: Biblos, 2018.

HARVEY, D. A Condição Pós-Moderna: Uma pesquisa sobre as origens da mudança cultural. São Paulo: Loyola, 1989.

JAGUARIBE, H. Autonomía periférica y hegemonía céntrica. Estudios Internacionales, v.12, n. 46, pp. 91-130, 1979.

JAGUARIBE, H. Dependencia y autonomía en América Latina. In: JAGUARIBE, H.; FERRER, A.; WIONCZEK, M. S.; SANTOS, T. dos. La dependencia político-económica de América Latina. Buenos Aires: Siglo XXI Editores, 1973, pp. 1-85.

JAGUARIBE, Hélio. Desarrollo económico programado y organización política (un intento para aclarar contradicciones). Desarrollo Económico, v. 2, n. 1, p. 5-64, 1962.

JAGUARIBE, Hélio. Desarrollo económico Y desarrollo político. Buenos Aires: Editorial de Buenos Aires, 1968.

JAGUARIBE, Hélio. La política internacional en los años 8o. In: JAGUARIBE, H. et al. La política internacional de los años 80: Una perspectiva latinoamericana. Buenos Aires: Editorial de Belgrano, 1982. pp. 11-21.

JAGUARIBE, Hélio. Urgências e perspectivas do Brasil. Brasília: FUNAG, 2005. KAPLAN, Marcos. El Estado en el Desarrollo y la Integración de América Latina.Ensayos. Caracas: Monte Ávila Editores, 1969. 
LIMA, Maria Regina Soares de. Enfoques analíticos de política exterior: el caso brasileño. In: RUSSELL, R. (Comp.) Enfoques teóricos y metodológicos para el estudio de la política exterior. Buenos Aires: Grupo Editor Latinoamericano/RIAL, 1992. pp. 53-83.

LIMA, Maria Regina Soares de. Relações interamericanas: A nova agenda sul-americana eo Brasil. Lua Nova, [s./v.], n. 90, pp. 167-201, 2013.

LORENZINI, María Elena. Pensando desde el Sur: ideas, aportes y contribuciones teórico-conceptuales de Hélio Jaguaribe para comprender las realidades latinoamericanas. In:SIMONOFF, A. (Comp.). Los Pensadores del Cono Sur: Los aportes de Jaguaribe, Methol Ferré, Puig Y Tomassini a las Relaciones Internacionales. La Plata: Universidad Nacional de La Plata, 2014. pp. 13-33.

MOURA, G. Autonomia na dependência: A política externa brasileira de 1935 a 1942. Rio de Janeiro: Editora Nova Fronteira, 1980.

MUÑOZ, L. R. O conceito de autonomia em Puig e Jaguaribe: uma análise comparativa intertextual. Carta Internacional, v. 11, n. 2, pp. 200-221, 2016.

O'DONNELL, G. \& LINCK, D. Dependencia Y autonomía. Formas de dependencia Y estrategias de liberación. Buenos Aires: Amorrortu, 1973.

ODDONE, C. N. \& GRANATO, L. La teoria dell'autonomia applicata ai nuovi processi di integrazione regionale latinoamericani. Il Politico: Rivista Italiana di Scienze Politiche, [s./v.], n. 1, pp. 183-200, 2009.

OLIVER-COSTILLA, L. F. O Estado latino-americano perante a mundialização do capital. Revista de Ciências Sociais, v. 28, n. 1/2, pp. 7-24, 1997.

PINHEIRO, L. Traídos pelo desejo: um ensaio sobre a teoria e a prática da Política Externa Brasileira contemporânea. Contexto Internacional, v. 22, n. 2, pp. 305-335, 2000.

PUIG, J. C. Doctrinas internacionales $Y$ autonomía latinoamericana. Caracas: Universidad Simón Bolívar, 1980.
PUIG, J. C. Introducción. In: PUIG, J. C. (Comp.) América Latina: Políticas Exteriores Comparadas. Buenos Aires: Grupo Editor Latinoamericano/RIAL, 1984. pp. 24-90.

ROBINSON, W. América Latina y el capitalismo global. Una perspectiva crítica de la globalización. México: Siglo Veintiuno, 2015. RUSSELL, R. \& TOKATLIAN, J. G. Autonomía Y neutralidad en la globalización: una readaptación contemporánea. Buenos Aires: Capital Intelectual, 2010.

RUSSELL, R. \& TOKATLIAN, J. G. From Antagonistic Autonomy to Relational Autonomy: A Theoretical Reflection from the Southern Cone. Latin American Politics and Society, v. 45, n. 1, pp. 1-24, 2003.

SAINT-PIERRE, H. L. "Defesa" ou "Segurança"? Reflexões em torno de Conceitos e Ideologias. Contexto Internacional, v. 33, n. 2, pp. 407-433, 2011.

SARAIVA, J. F. S. Autonomia na inserção internacional do Brasil: um caminho histórico próprio. Contexto Internacional, v. 36, n. 1, p. 9-41, 2014.

SARTI, I. Desafios à Esquerda. Notas sobre a Integração em tempos de crise. In: SIERRA, G. (Org.) Los progresismos en la encrucijada: Argentina, Bolivia, Brasil, Uruguay, Venezuela. Montevideo: Udelar, 2017. p. 99-110.

SIMONOFF, A. Las expresiones autonómicas del Cono Sur: Jaguaribe, Puig, Tomassini, Linck y O'Donnell. Cadernos PROLAM/ USP, v. 13, n. 25, pp. 13-27, 2014.

TOLEDO, Caio Navarro de. Estado nacional e desenvolvimento capitalista no Brasil. In: COSTA, S. (Comp.) Concepções e formação do Estado brasileiro. São Paulo: A. Garibaldi - UCG, 2004.

TREACY, M. Discusiones sobre la autonomía en la recepción de los aportes dependentistas al campo de las Relaciones Internacionales y contribuciones recientes desde el enfoque de cadenas globales de valor. Revista Aportes para la Integración Latinoamericana, [s./v.], n. 38, pp. 45-67, 2018. 
VIGEVANI, T. \& CEPALUNI, G. A política externa brasileira: a busca da autonomia, deSarney a Lula. São Paulo: Editora UNESP, 2011.

VIGEVANI, T. \& RAMANZINI Jr., Haroldo. Autonomia, Integração Regional e Política Externa Brasileira: Mercosul e Unasul. DADOS - Revista de Ciências Sociais, v. 57, n. 2, pp. 517-552, 2014.

VISENTINI, P. G. F. Dez anos que abalaram o século XX. Porto Alegre: Novo Século, 1999b.

VISENTINI, P. G. F. Eixos do poder mundial no século XXI: Uma proposta analítica. Austral: Revista Brasileira de Estratégia e Relações Internacionais, v. 8, n. 15, pp. 9-25, 2019.
VISENTINI, P. G. F. O Brasil e o mundo: a política externa e suas fases. Ensaios FEE, v. 20, n. 1, pp. 134-154, 1999a.

VISENTINI, P. G. F. Relações internacionais do Brasil: de Vargas à Lula. São Paulo: Fundação Perseu Abramo, 2003.

ZIEMATH, G. G. S. O conceito de autonomia na Política Exterior Brasileira: mudanças e continuidades. In: INSTITUTO RIO BRANCO. Caderno de Ensaios: Primeiro. Brasília: Instituto Rio Branco, 2015. pp. 127-164.

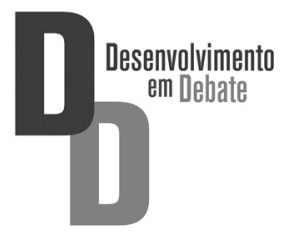




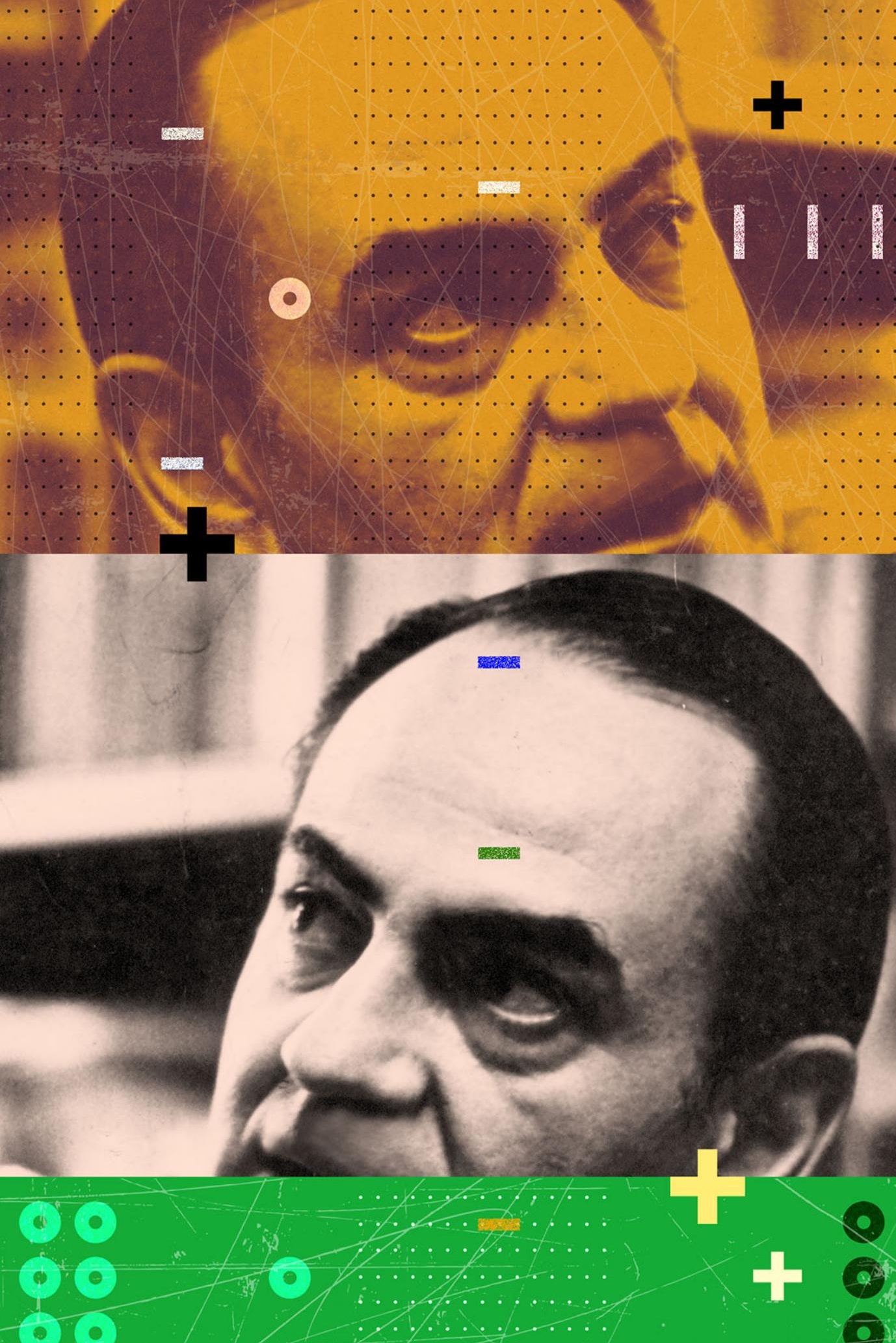




\title{
Dos Cadernos ao neobismarckismo: o primeiro momento de Hélio Jaguaribe
}

\author{
Hélio Jaguaribe's first moment: from \\ ISEB to Neo-Bismarckism
}

\author{
Fernanda Xavier da Silva*
}

\begin{abstract}
Resumo
O presente artigo procura analisar o primeiro momento da obra de Hélio Jaguaribe: momento que assinala o surgimento, a maturação, e posterior consolidação do projeto desenvolvimentista no governo JK. A nosso ver, a busca pelo desenvolvimento é central, móvel mesmo do pensamento do autor. Isso não significa, porém, que suas ideias não passem por alterações. Mudam suas fontes teóricas, mudam os problemas, mudam os desafios postos pelo contexto, consequentemente, muda também a concepção de desenvolvimento do autor. Sob uma perspectiva genética e cronológica, o presente artigo examina os principais temas, problemas, ideias de Hélio Jaguaribe, como eles foram elaborados e modificados pari passu às transformações experimentadas por seu contexto específico.
\end{abstract}

Palavras-chave: Pensamento social brasileiro; Desenvolvimentismo; Hélio Jaguaribe.

\begin{abstract}
This article seeks to analyze the first period of Hélio Jaguaribe's work: moment that marks the advent, maturation, and subsequent consolidation of the developmentalist project in JuscelinoKubitschek's government (1956-1961). The search for economic development is a central feature in author's thinking. This does not mean, however, that his ideas do not change. His theoretical sources change, the problems change, the challenges posed by the context change, so the author's conception of development also changes. In this way, from a genetic and chronological perspective, this article examines the main themes, problems, and ideas of Hélio Jaguaribe, and how they were elaborated and modified throughout the transformations ofdifferent particular contexts.
\end{abstract}

Keywords: Brazilian social thought; Developmentalism; Hélio Jaguaribe. 


\section{INTRODUÇÃO}

Ao longo de seus noventa e cinco anos de vida Hélio Jaguaribe publicou cerca de quarenta livros e diversos artigos sobre os mais variados assuntos. O próprio autor dividiu sua atividade intelectual em seis diferentes áreas: 1 ) trabalhos teóricos no plano da Ciência Política e da Sociologia; 2) estudos no campo de Relações Internacionais; 3) trabalhos sobre América Latina; 4) estudos filosóficos; 5) trabalhos relacionados com o desenvolvimento; e 6) estudos histórico-sociológicos (JAGUARIBE, 2000). Isto posto éinviável propor uma análise do conjunto da obra, como também improcedente. $\mathrm{Na}$ medida em que as ideias tendem a responder aos desafios colocados pelo contexto específico, é evidente que o que Hélio Jaguaribe escreveu em 1950 é bastante diferente do que escreveu quer durante o período da ditadura, quer nos anos 1990 ou 2000. Frente a isso, analisamos aqui somente aquilo que, segundo Bresser-Pereira, designa o primeiro momento desta produção: momento que assinala o surgimento, a maturação, e posterior consolidação do projeto desenvolvimentista no governo JK, "quando aindustrialização era o grande desafio do país" (BRESSER-PERIERA, 2000, p. 237)1.

A nosso ver, já no primeiro trabalho de Hélio Jaguaribe encontramos o cerne da obra, aqui analisada: o Brasil vivencia uma conjuntura de crise, cuja resolução passa pela elaboração de uma nova ideologia em sentido ao desenvolvimento. A busca pelo desenvolvimento não apenas perpassa toda sua obra, como é o principal móvel de suas ideias. Isso não significa dizer que suas ideias não mudem, ou que sua concepção de desenvolvimento permaneça sempre a mesma. Mudam suas fontes teóricas, mudam seus problemas, mudam os desafios postos pelo contexto. Compreender as transformações experimentadas em seu pensamento, como as causas, tipos, concepção de crise e de desenvolvimento mudam ao longo do tempo, resultado quer da própria maturação de suas ideias, quer dos diferentes desafios experimentados, é o objetivo do presente artigo. Apreciamos, pois, esse primeiro momento do autor, todos os livros e artigos publicados entre 1950 e 1964, sob uma perspectiva genética e cronológica. Isto implica estudar a obra, as ideias do autor enquanto um processo, algo em movimento, "objeto de disputas cognitivas e políticas" em um dado ambiente histórico-sociológico, jamais como realidade ontológica estável (BITTENCOURT, 2011, p. 11).

\section{O PRIMEIRO MOMENTO DE HÉLIO JAGUARIBE:}

Em primeiro lugar, é importante termos em mente as referências teóricas de Hélio Jaguaribe antes de passarmos à análise de seu discurso. Nos três 
artigos publicados na Revista Brasileira de Filosofia (1951 - Que é filosofia?; 1952 - uma resenha do livro de Karl Jasper intitulada Origem e meta história; e 1954 - A crise da universidade) e no texto A Filosofia no Brasil, originalmente publicado no Jornal do Comércio em 1952, Jaguaribe realiza um debate teórico a respeito dos temas em questão. Destaca aí a "falta de originalidade e de autenticidade da filosofia brasileira", que se faria sentir, na transplantação de fórmulas e doutrinas independentemente "das relaçóes dialéticas entre as estruturas econômica, social e cultural e normas de poder” do país (JAGUARIBE, 1957a, p. 20). Retoma um debate de longa tradição no pensamento social brasileiro que aponta para a inautenticidade das ideias e instituiçôes nacionais. Embora tais obras se situem em um plano mais filosófico, já aí Jaguaribe deixa entrever o conteúdo mais prático de seu pensamento: procura a todo o momento, influenciar os rumos dos acontecimentos, "superar a crise não só brasileira, mas ocidental” (TOLEDO, 1982, p. 97).

Segundo Vanilda Paiva, isso reflete a forte influência das ideias de Ortega y Gasset sobre o autor. Ao pressupor a crise brasileira como uma crise da cultura - não oferece mais "ideias e instrumentos adequados à interpretação da realidade transformada", levando ao "surgimento de brechas, falhas entre a cultura ambiente e o mundo que se transforma", - Jaguaribe, mais do que qualquer outro isebiano ${ }^{2}$, analisa a circunstância brasileira sob a mesma chave consagrada por Ortega: "a civilização dominada pela técnica e a ascensão das massas, sua rebelião" (PAIVA, 1980, p. 34). Para Paiva, os primeiros trabalhos de Jaguaribe consagram um esforço intelectual no sentido de interpretar a "realidade transformada para, através dela, recompor as brechas abertas pela mudança”" (PAIVA, 1980, p. 35).

Embora, mais a frente, a autora entenda que ao procurar diagnosticar a crise brasileira Jaguaribe tenha abandonado o plano da especulação, o vitalismo orteguiano em favor de uma postura mais ativa, militante - passaria do "culturalismo especulativo ao culturalismo militante, da filosofia à ciência política, das preocupações com o indivíduo à preocupação com a realidade econômica” (PAIVA, 1980, p. 37) - Celso Lafer lembra bem que na concepção de Ortega "o intelectual deve ter um papel diretivo e de renovação da sociedade”. Daí Jaguaribe atribuir-se da missão de vertebrar o Brasil, procurar "promover e incrementar a racionalidade pública", buscando converter a “moeda da cultura em moeda da influência”, à imagem de Ortega (LAFER, 2000, p. 80).

É importante notar que aos conceitos de época, fase, estrutura-tipo (da matriz orteguiana), somam-se, no pensamento autor, a ideia de ajustamento faseológico das nossas ideias e crenças, os conceitos de representatividade e 
de autenticidade. Clara influência de Pareto, de Max Weber, Alfred Weber e sobretudo de Karl Mannheim ${ }^{3}$. São esses autores que fornecem a Jaguaribe as bases sobre as quais apoia o nacional desenvolvimentismo; "ideologia que favorecia a transformação e o progresso" fundamental para "sedimentar a nova fase”, superar a crise do nosso tempo (PAIVA, 1980, p. 40).

\section{A crise do nosso tempo e do Brasil}

Já na Apresentação do primeiro número da revista Cadernos do Nosso Tempo Hélio Jaguaribe caracteriza sua época (anos 1950) como uma época problemática, uma época de crise. Resultado da "perda de validade ou vigência das crenças" que pautavam a conduta das épocas precedentes, da instabilidade da vida, "sujeita a crises econômicas e sociais que se superpóem", da alienação causada pela "massificação e proletarização" e da "precariedade das coisas, sob o risco iminente da aniquilação atômica”, entende que o próprio viver tornou-se um problema (JAGUARIBE, 1953a, p. 02). É, porém, no texto $A$ crise do nosso tempo e do Brasil que tal questão se encontra melhor matizada.

Segundo Jaguaribe, o problema do seu tempo é resultado da conjunção de duas crises. De um lado há a crise das crenças, quando o cristianismo, apesar de se manter como essência da religião e cultura ocidentais, "não consegue mais ordenar coerente e sistematicamente nossas crenças e nossos valores", haja vista a ascensão do racionalismo e do marxismo (JAGUARIBE, 1954a, p. 06). De outro lado, verifica-se uma crise das ideologias resultado do colapso tanto da liberal-democracia, como do socialismo5. No que concerne ao Brasil, para o autor, o problema reside justamente em sentir tais crises sob a forma particular que as condições do país imprimem. Ou seja, sem apresentar um contexto semelhante ao qual essas crises derivaram. Isso apontaria, pois, para "o desajustamento e o descompasso entre nossas instituiçóes e nossa realidade e entre nossas posições ideológicas e nossas verdadeiras instituições" (JAGUARIBE, 1954a, p. 11).

Conforme o autor, a alienação colonialista brasileira - expressão do retardamento cultural e econômico do país - faz com que consideremos os problemas nacionais "segundo a perspectiva dos interesses alienígenas", quando devíamos fazê-lo "a partir da realidade brasileira, da posição do Brasil na América Latina e desta no mundo" (JAGUARIBE, 1953a, p. 2). Entende que é preciso compreendermos concretamente a realidade, para "fundamentar uma ação autêntica, apoiada na interpretação das possibilidades e das necessidades do homem brasileiro, nas condiçôes de lugar e tempo" (JAGUARIBE, 1953a: p. 2). Isso explica a inscrição contida na contracapa 
dos cinco números da revista: os problemas do nosso tempo na perspectiva do Brasil; os problemas do Brasil na perspectiva do nosso tempo.

Segundo Jaguaribe, A crise brasileira apresenta dois planos de profundidade, o estrutural e o conjuntural, e quatro aspectos básicos: econômico, social, cultural epolítico (JAGUARIBE, 1953b). A crise econômica é resultado do fato de o Brasil ter ultrapassado o nível de tolerância do processo de subdesenvolvimento. Isto é, por termos uma economia pautada na monocultura de exportação, e dependermos crescentemente de certas matérias primas e de maquinaria, nosso saldo do balanço de pagamentos tornou-se insuficiente ante as atuais exigências de importação. Acrescentando a isso o alto custo da produção nacional - fruto da dependência da importação, baixa racionalização da produção, e/ou da insuficiência da infraestrutura nacional, - a baixa acumulação de capital e a baixa formação de tecnologia, eis que a economia brasileira se tornou incapaz de atender a demanda interna ${ }^{6}$.

Tal configuração, por sua vez, acabou por gerar novos fenômenos de subdesenvolvimento expressos na desproporção crescente entre a renda dos assalariados e dos proprietários e entre as diferentes regióes do país. Intensificados por um contexto de inflação, dada a imoderada expansão do crédito, formou-se nacionalmente uma conjuntura de escassez-carestia quer por efeito deliberado - resultado do monopólio ou oligopólio de alguns setores tal como o de transporte, - quer involuntariamente - produto da insuficiência de bens e serviços, de transporte e armazenamento ou da concentração tanto da demanda, como da concorrência (JAGUARIBE, 1953b, p. 121).

Já a crise social consiste na transformação da tensão entre as classes num antagonismo irredutível resultado do baixo índice de renovação das elites dirigentes, acompanhado da pressão ascendente das camadas populares e da decadência do capitalismo. Conforme o autor, as transformaçóes pelas quais o país passou ao longo de sua história significaram o solapamento das bases em que se assentavam o domínio da burguesia latifundiária e da classe média, impelindo à participação das massas no processo econômico e político. Todavia, com base em uma prática demagógico-assistencialista responsável por uma série de promessas ao proletariado, tais classes conseguiram asseverar a manutenção da política de clientela7 e do regime agroexportador. Como resultado, ampliou-se o antagonismo entre as massas e elites, cuja principal consequência foi tanto impedir a formação de um projeto de convivência das classes, como acentuar "os egoísmos de classe, o imediatismo oportunista dos indivíduos e as tendências dissociativas" (JAGUARIBE, 1953b, p.129).

No que tange ao aspecto cultural, para Jaguaribe, a crise consiste no agravamento da incultura nacional. Isso ocorre primeiramente dada a prática da 
economia de exploração: por auferir seus proventos da simples plantação e/ ou do comércio, a burguesia latifundiária e urbana não precisou "aprimorar técnicas complexas para assegurar sua subsistência”, atenuando assim as provocações do meio rural responsáveis pela formação da cultura (JAGUARIBE, 1953b, p. 130). Ao mesmo tempo, ao parasitar em torno do Estado, a classe média não foi levada a desenvolver modernos mecanismos administrativos. Somando a isso as características da colonização portuguesa - não apenas impediu o florescimento de uma cultura nacional, como por não ter sido atingida pela Reforma não forjou novos instrumentos mentais para compreender o mundo moderno, - o Brasil mostra-se culturalmente despreparado para enfrentar a crise do seu tempo. Conforme Jaguaribe: nosso pensamento não dispóe de categorias "para equacionar a problemática filosófica e sociológica do mundo contemporâneo”, e carece de conhecimento técnico e administrativo para enfrentar as tarefas da vida econômico-social (JAGUARIBE, 1953b, p. 130).

Por fim, segundo o autor, a crise política "exprime as dificuldades e desorientação" indicada nos itens precedentes: assinala o colapso do sistema cartorial $^{8}$ praticado desde o Império. Para Jaguaribe, a expansão dos fatores de produção, quando das duas guerras mundiais, significou o aumento da demanda por serviços públicos efetivos; demanda incompatível com a estrutura do Estado Cartorial. Somando a isso ofato de que, no plano das relaçóes internacionais, os Estados passaram crescentemente a intervir em favor de seus interesses econômicos, faltava ao Estado brasileiro a estrutura necessária para tal, tornando-o "presa dos Estados que programam e executam coerentemente uma tal política” (JAGUARIBE, 1953b, p. 143). Isto se revela ainda mais grave, pois se trata de um contexto de formação de uma hegemonia mundial cuja principal tendência é a do "Estado vencedor exercer uma política de economia de exploração em relação aos demais países, tanto mais acentuadamente quanto menor for a capacidade de resistência de cada país” (JAGUARIBE, 1953b, p. 144).

Tal interpretação é um retrato da conjuntura brasileira da época em que o autor escreve. Período marcado pela perda de poder por parte das oligarquias e crescimento de novas classes sociais, sobretudo do operariado urbano que passa a exigir melhores condiçôes de vida e trabalho, sem dispor, porém, de canais regulares de representação política. Período em que o processo de industrialização se desenvolve de forma mais acentuada que nos anos 1920, mas ainda é obstado pelo déficit no balanço de pagamentos, inflação ou mesmo pela migração do campo-cidade que passa a pressionar o mercado. Coloca, pois, em pauta a necessidade de reformar o Estado tanto para integrar essas novas classes, ampliar a oferta serviços públicos, como 
para construir um caminho para o desenvolvimento do país controlando o avanço da política populista bem como as ameaças golpistas.

Que rumo tomar? Tal resposta deixa entrever os diferentes contextos em que o autor escreve. Expressa a perspectiva do Brasil, então extremamente mutante.

\section{A perspectiva do Brasil}

Segundo o autor, tendo em vista que um dos maiores problemas de sua época consiste no esgotamento das crenças que presidiram nossa formação, a solução à crise nacional comportaria dois aspectos distintos: de um lado, "o repertório de providências suscetíveis de corrigir as mais graves deficiências de que se ressente o país", de outro lado, "a ideologia de que esse programa seja um corolário e a cujos princípios esteja vinculado” (JAGUARIBE, 1953 b, p. 138). Com relação ao primeiro aspecto, seu diagnóstico é mais ou menos perene ao longo de sua obra.

No plano econômico: "a) regulamentação das aplicações, da renda nacional, destinada a ensejar a máxima capacidade de investimento; b) rigoroso controle de intercâmbio internacional, visando a aumentar as exportaçôes, reduzir as importações e selecionar a utilização de divisas; c) reaparelhamento geral, segundo escalas de prioridade por atividade econômica e por regióes; d) racionalização e tecnificação da produção".

No plano social: "a) liquidação dos privilégios hereditários e das formações fechadas de classe; b) promoção da circulação de elites, visando a criar quadros dirigentes dotados de efetiva representatividade e exemplaridade; c) formação de um movimento social apoiado numa ideologia e assentado por uma programática aptos a suscitar confiança no futuro e anseio pela realização dos objetivos prefixados".

No plano cultural: "a) criação da cultura brasileira, com a incorporação do patrimônio espiritual do ocidente e a formação de uma compreensão viva da realidade nacional; b) desenvolvimento de uma ação tendente a retirar o máximo de rendimento da crise como fator estimulante da cultura; c) reforma da educação, tornando-a compulsória e geral, orientada para a compreensão e o domínio de nossas circunstâncias e apta a exercer uma ampla seleção de valores; d) imediata criação de um amplo quadro de técnicos e de administradores".

No plano político: "a) liquidação do Estado Cartorial e do parasitismo burocrático e instituição do Estado-serviço e da administração produtiva e eficaz; b) instauração de uma política interna calcada num planejamento geral da ação do Estado em todos os planos da vida nacional; c) instauração de uma política externa calcada na objetiva compreensão dos interesses do Brasil na órbita internacional; d) urgente atendimento dos mais imperativos interesses do país sujeitos à pressão direta ou indireta de outros Estados". (JAGUARIBE, 1953b, p. 138 a 141). 
A mesma constância não se verifica no que concerne à ideologia capaz de "atender as solicitações específicas para integrar, num sistema de crenças e ideias, a programática exigida pelos referidos problemas” (JAGUARIBE, 1953 b, p. 142). No texto de 1953 Jaguaribe entende que a ideologia "apta a integrar, num sistema conjunto, suscetível de eficácia histórica, as soluções requeridas pela problemática nacional” passaria pela desprivatização dos meios de produção - receita fortemente influenciada pelo contexto internacional de Guerra Fria, expressão da busca por uma política de terceira posição. Já nos textos seguintes, os rumos dos acontecimentos parecem levar o autor a pensar a situação brasileira não mais em relação ao quadro global, mas em função dos seus dilemas internos. A crise do governo Vargas (oposição UDN, movimento grevista organizado pelo PCB ainda na ilegalidade), bem como o nacionalismo deste - o que leva os EUA suspenderem a emissão de recursos para o Brasil entre 1954 e 1958, - faz com que seu foco passe da simples adoção de uma postura de terceira posição, à elaboração e adoção de uma ideologia nacional-desenvolvimentista (JAGUARIBE, 1953b: p. 149).

Já no segundo número de Cadernos do Nosso Tempo, no artigo sobre a Situação politica brasileira Jaguaribe pressupóe como sua nota mais característica o enfraquecimento do poder civil. Conforme o autor, o Brasil vivencia uma forte crise política, resultado da crescente inadequação das instituições em relação à realidade nacional. Não se trataria apenas de uma crise do governo, mas uma crise das instituições oficiais e representativas da sociedade civil, que "carecem de sua presumida representatividade" (JAGUARIBE, 1954b, p.104).

No âmbito da governança, tal crise se assemelharia à crise de 1945, quando o governo tentou transferir, sem sucesso, sua base social para as classes trabalhadoras. Uma vez que estas ainda não tinham condições de arcar com tal responsabilidade, isto significou a perda de suas bases - "hostilizado pela classe mercantil”, o governo não soube conservar "o apoio da burguesia industrial e da classe média” e não logrou encontrar bases suficientes no proletariado (JAGUARIBE,1954b, p. 110). Contribui para isso a crise da própria oposição que "não se mostra capaz de traçar rumos próprios, em substituição aos que critica", a heterogeneidade econômico-social do país responsável pela fragmentação interna dos partidos (que, de fato, continuam regionais), e falta de sentido ideológico e programático dos mesmos. Daí que, segundo o autor, "ideológica e programaticamente, todos os nossos partidos são iguais, se confundem na mesma falta de ideias e orientação" (JAGUARIBE, 1954b, p. 111). 
Somando isso à organização clientelística dos nossos partidos, eis que se institui nacionalmente um divórcio entre a dinâmica político-eleitoral e a econômico-social. Isto é, as forças ligadas ao meio rural "logram prevalecer na política partidária, imprimindo suas características e interesses” quando já são as classes urbanas as responsáveis pelo desenvolvimento do país (JAGUARIBE, 1954b, p. 118).

Conforme Jaguaribe, essas crises tendem a serem superadas apenas através da formação "de uma frente comum, econômica, social e política, que mobilize as forças eos interesses mais aptos a promover o desenvolvimento nacional" de modo a impor a prevalência desses interesses e dessas forças sobre "as forças e interesses comprometidos com o status quo e o subdesenvolvimento" (JAGUARIBE, 1954b, p. 117-118). Uma vez que, nesse contexto, nenhum partido representa ou pode representar essas forças, defende a formação de um movimento novo que "apoiado nessas forças eliderado por seus mais significativos representantes" possa levar a cabo o que considera um "grande esforço de salvação nacional” (JAGUARIBE, 1954b, p. 120).

Seguindo esta tônica - "agravamento da inautenticidade de nossas instituições políticas (...) quando apreciadas em função da dinâmica do processo econômico-social” Jaguaribe analisa os fatos e movimentos políticos característicos do período (o moralismo, o golpe de agosto e a sucessão presidencial de $1955^{\circ}$ ), repensando e aprofundando o debate sobre a crise brasileira (JAGUARIBE, 1954b, p. 117). Isso desemboca no artigo publicado na Revista do Clube Militar de 1955 em que o autor apresenta uma nova proposta para o Brasil.

Conforme o autor, estudar a Situação atual do Brasil exige que pensemos o "estado em que atualmente se encontra o processo histórico-social brasileiro mediante análise histórica sociológica do mesmo" (JAGUARIBE, 1955 b, p. 05). Pressupondo o primeiro como resultado da interação de quatro ordens de fatores - os ideais (conjunto de crenças substantivas), os reais (condições materiais do meio físico), a liberdade e oocaso (refere-se ao fato de determinado evento ter se verificado em certo lugar e de certo modo), - Jaguaribe avalia o processo social “em função de sua faseologia”. Ideia esta que passa, agora, a ser central em sua obra.

Termo cunhado por Guerreiro Ramos, consiste no reconhecimento de que "as comunidades pertencentes a um mesmo processo histórico global tendem a percorrer as fases determinadas pelo curso desse processo" (JAGUARIBE, 1955b, p. 5). Cada uma dessas fases, por sua vez, constitui uma estrutura-tipo de relaçóes que orientam toda a vida da comunidade; segue leis gerais caracterizando uma estrutura econômico-social específica. 
Nesse sentido, o entendimento da atual situação brasileira passa pela "compreensão da estrutura-tipo segundo a qual se ordena nossa comunidade", acompanhada da compreensão da faseologia de suas origens (JAGUARIBE, 1955b, p. 7).

No que tange ao primeiro aspecto Jaguaribe pressupóe a estrutura-tipo do Brasil como "a de uma comunidade ainda marcada por características semicoloniais em estado de subdesenvolvimento econômico-social, mas em fase de acentuado desenvolvimento, ora obstado por determinados pontos de estrangulamento" (JAGUARIBE, 1955b, p. 7). Isso se faria sentir ante a estrutura de nosso comércio exterior - ainda dependente da exportação de um único produto primário e destinado a um só mercado importador e nossa subcapitalização, que nos levaria a pensar a questão do subdesenvolvimento.

Caracterizando como subdesenvolvidas as economias que "por deficiências de seus fatores de produção" não disponham, por conta própria, "da possibilidade de dar aos seus fatores, em regime de pleno emprego, a máxima utilização permitida pela técnica existente", o subdesenvolvimento se faria sentir aqui não por meio da estagnação, mas através de elevadas taxas de crescimento, porém ainda bastante tumultuário e heterogêneo - "com relação aos diversos setores da economia e às diversas regióes do país" - e enfrentando graves obstáculos (JAGUARIBE, 1955b, p. 8).

Isso nos remete à faseologia da situação brasileira. Conforme o autor, a história econômico-social do Brasil divide-se em três fases distintas:

(...) a primeira é a fase de economia de produção escravocrata e vai desde os primórdios da colonização até meados do século XIX. A segunda é a fase da economia semicolonial de exportação e vai de meados do século, a partir da abolição do tráfico de escravos e de sua progressiva substituição pelo trabalho assalariado, até a crise do café em 1930. A terceira fase é a fase de transição para a autonomia econômico-social do país que, iniciada em 1930 e acelerada com a II Guerra Mundial, prossegue até nossos dias (JAGUARIBE, 1955b, p. 9).

Enquanto na primeira fase o Brasil apareceria mais como uma parte descentralizada da Europa por sua produção de artigos para exportação, a segunda caracterizar-se-ia "pela formação da sociedade brasileira, sua diferenciação em classe e seu enriquecimento” (JAGUARIBE, 1955b, p. 9).

Conquanto dotado de vida e economia próprias, segundo Jaguaribe, o desenvolvimento do Brasil continua dependente da situação econômica mundial, já que é o café a base de nossa economia. Somente na terceira fase - impelido pelo contexto de crise econômica dos anos 1920, reforçado, posteriormente, pelo o conflito mundial - éque a indústria se torna a principal fonte de renda nacional. Ainda assim, na medida que a situação nacional 
é marcada pela dilapidação dos saldos cambiais e pela posse de uma infraestrutura precária, somada ao contexto global de ausência de financiamento externo, configurar-se-ia a crise que vivenciávamos (JAGUARIBE, 1955b, p. 9).

Considerada à luz de seu processo formativo, a estrutura-tipo de que atualmente se reveste o processo econômico-social brasileiro representa o resultado de uma progressiva descolonização da nossa economia, cujo desenvolvimento se tornou possível na medida em que ela se transformava numa economia nacional. Considerada à luz de suas tendências, se revela insuscetível de perduração, marca uma fase logicamente transicional (JAGUARIBE, 1955b, p. 11).

Trata-se de uma estrutura em transição. Como tal, seu equilíbrio deve se estabelecer "mediante uma reorganização dessa estrutura-tipo" quer pelo nível mais alto, quer pelo mais baixo, a depender da ideologia que se sagrará vencedora (JAGUARIBE, 1955b, p. 11).

Conforme Jaguaribe, das quatro tendências ideológicas em disputa nacionalmente - correspondentes às classes latifúndio-mercantis, pequenoburguesa, industrial e proletária, - a fórmula que representaria a transição para uma etapa mais avançada do processo faseológico era a encampada pelas classes industrial e operária. Reconhece, assim, como ideologia mais autêntica a ideologia do desenvolvimento econômico-social. É justamente neste ponto que o debate, até então um pouco dilatado, revela ser um debate meramente econômico.

Pressupondo que os problemas do Brasil são bastante simples porque "as questôes mais importantes e urgentes são as que se referem à produção e à produtividade" e não à distribuição, Jaguaribe propóe pensar as medidas necessárias para consolidar finalmente a passagem do Brasil da fase semicolonial à fase de pleno desenvolvimento (JAGUARIBE, 1956b: 54). Conquanto esse raciocínio e base teórica permeiem todos seus demais trabalhos, entendemos ser possível dividir tal produção em três fases específicas: uma primeira marcada pelo debate econômico e, em menor medida, o político e cultural; uma segunda em que ganha força o debate acerca do nacionalismo; e uma terceira em que o autor retorna à temática do desenvolvimento econômico, porém munido de uma análise mais elaborada ${ }^{10}$.

As diferentes fases do primeiro momento de Hélio Jaguaribe

O debate econômico

Integram essa fase os textos Para uma politica nacional de desenvolvimento (1956), O problema do desenvolvimento econômico e a burguesia nacional (1956) e Condiçóes institucionais ao desenvolvimento (1958). Textos que 
apresentam preocupações de ordem social e política, mas têm a questão econômica como central; é ela que orienta o debate. Retomando o raciocínio já apresentado - conhecer o Brasil exige que estudemos "o processo político brasileiro em face e em função da atual estrutura-tipo do Brasil”, e ao mesmo tempo levemos em conta "o processo faseológico dessa estrutura", - Jaguaribe procura pensar as medidas necessárias para "promover o crescimento de nossa economia sem que ela seja destruída pelos desequilíbrios que tal crescimento ocasiona" (JAGUARIBE, 1956b, p. 89).

De acordo com o autor, "os desequilíbrios estruturais" que a economia brasileira experimenta, "em consequência mesmo de seu crescimento”, só podem ser "superados com a definitiva transformação da atual estrutura-tipo"; isto é, consolidando o desenvolvimento (JAGUARIBE, 1956b, p. 90). Para tal, faz-se necessário reequilibrar a balança comercial, aumentando as exportações ao passo que se substituem as importações, expandir a infraestrutura de modo a atender a demanda interna por transporte e energia. Uma vez que isso requer grande volume de capital, item em falta nacional e internacionalmente, faz-se mister uma "intervenção planificadora do Estado" que, direta ou indiretamente, "organize a economia, estimule ou desestimule determinadas atividades, coordene fatores, discipline os investimentos e assuma, promocional ou supletivamente, certos encargos produtivos" (JAGUARIBE, 1956b, p. 94). Isto, por sua vez, demanda certas condiçóes institucionais. Sugere, pela primeira vez, a ideia de que o desenvolvimento é um processo social global.

Conforme o autor, "o fenômeno do desenvolvimento econômico é um aspecto particular do fenômeno do crescimento econômico". Envolve não apenas a acumulação quantitativa das riquezas, mas também a transformação qualitativa do processo econômico, por vincular-se ao "aproveitamento ótimo e crescente das possibilidades tecnológicas" na utilização dos recursos disponíveis (JAGUARIBE, 1958, p. 37). É um processo que ocorre no âmbito das relações econômicas, mas não está a ele limitado; tanto as mudanças na estrutura produtiva ocorrem a partir de condições mais amplas, tais como crenças e hábitos de uma comunidade, como ao se processarem, no plano econômico ou em qualquer outro, provocam igual efeito nas outras áreas da vida social. Daí que o planejamento democrático da economia, tendência da economia do seu tempo, é "insuscetível de aplicação e de realização se não estiver enquadrado em um contexto que propicie a sua execução" (JAGUARIBE, 1958, p. 48).

Se no âmbito do diagnóstico o autor pensa (ou diz pensar) em termos globais, o mesmo não se verifica no que concerne ao seu prognóstico. Conforme o autor, "se considerarmos mais profundamente as relações entre o 
Estado e a economia, e "atentando ao fato de que, dado certo prazo, todo processo econômico tende a criar as instituições necessárias para discipliná-lo”, a melhor (e talvez a única) saída para superar os quatro planos da crise nacional, sobretudo o Estado Cartorial e a política de clientela é o desenvolvimento (JAGUARIBE, 1958, p. 29). Segundo Jaguaribe, a criação das condiçóes capazes de transformar "o antigo quadro do semicolonialismo do subdesenvolvimento" tende a alterar a estrutura estatal que ainda subsiste, impedindo assim que "as relações entre o homem público e o seu eleitorado" continuem a se processar com base em relações de barganha clientelística (JAGUARIBE, 1958, p. 30). Retoma as crises econômica, cultural, social e política já apresentadas, com pequenas mudanças.

Enquanto a crise social - agora expressa na manutenção de uma estrutura de privilégios de classe - e a crise cultural - manifesta na alienação cultural e, seu correspondente oposto, o nativismo primário - perdem em importância e profundidade, a crise política ganha. Pensada agora em termos da manutenção do clientelismo e cartorialismo (antes característicos da crise social), estabelece "um intervalo entre o processo econômico e o processo político" que suscita um "intervalo igualmente grave entre a estrutura do Estado Cartorial e sua efetiva capacidade de operação e as necessidades crescentes de verdadeiro serviço público" (JAGUARIBE, 1958, p. 27).

"Monstruosa deformação do serviço público", entre os anos de 1850 e 1930 expressou a "coincidência entre as forças que dominavam o processo econômico brasileiro e as que dirigiam politicamente o país” - permite a inserção da classe média via Estado Cartorial, ao passo que assegura a manutenção não apenas os privilégios da classe latifundiária, mas também o regime de produção primária, a rentabilidade e a funcionalidade de suas empresas. (JAGUARIBE, 1958, p. 23). Todavia, nos anos 50, pela sua própria eficácia, tal modelo é conduzido à contradição: ao garantir emprego à classe média marginalizada, cria condiçôes necessárias à formação de um mercado interno favorecendo o desenvolvimento econômico (JAGUARIBE, 1958, p. 24). Destrói, pois, suas próprias bases de sustentação, entrando em crise.

Nesse sentido, para Jaguaribe, o problema com que se defronta o Brasil é o de encontrar a fórmula capaz de superar as forças estáticas (as classes tradicionais, sobretudo a elite agrário-exportadora) e reajustar o Estado às forças dinâmicas (burguesia industrial e proletariado) que conduzem o processo social. O que nos falta, pois é alargar a propaganda do desenvolvimento, mostrando às grandes massas "a dependência que existe entre o processo econômico e a elevação do seu nível de vida” (JAGUARIBE, 1958, p. 49).

Uma vez que, para o autor, existe uma correspondência entre os interesses situacionais de classe - as demandas do proletariado, da burguesia 
industrial, do camponês e da classe média estão contempladas no desenvolvimento econômico, - falta apenas promover a mobilização ideológica da sociedade:

O problema que se apresenta, pois, para que se possa desencadear a ideologia do desenvolvimento e em torno dela reorganizar o aparelho do Estado e convertê-lo em Estado funcional, apto a planejar e a executar o planejamento econômico requerido pelas necessidades do país, éessencialmente, um problema de educação e de organização ideológica (...). É, portanto, por meio de um esforço ideológico e da organização de núcleos de coordenação e de esclarecimento sociais que (...) se poderá construir a grande unidade nacional para o desenvolvimento, formando-se correntes de ideias einteresses (...) suficientemente poderosos para transformar, no sentido do desenvolvimento, as condições institucionais do nosso país (JAGUARIBE, 1958, p. 53).

É perceptível que, não obstante tocar em questões de ordem política e social, o fim primeiro e último do autor é o desenvolvimento econômico. Em O problema do desenvolvimento econômico e a burguesia nacional, texto de caráter mais econômico, porque voltado à Federação das Indústrias de São Paulo, tal ideia fica ainda mais clara.

Conforme Jaguaribe, a substituição do Estado Cartorial por um Estado funcional é indispensável, posto que a promoção do desenvolvimento nacional exige "uma intervenção ordenadora e promocional do Estado apta a distribuir mais eficazmente os fatores disponíveis", função incompatível com o modelo estatal vigente. A demanda pela mobilização ideológica da sociedade, por sua vez, visa assegurar o apelo popular necessário para que as policies, elaboradas pela burguesia industrial para a solução dos problemas brasileiros, "encontrem o suporte das grandes massas e possam ser convertidas em ação administrativa corrente” (JAGUARIBE, 1956a, p. 45). Por fim a burguesia industrial desponta como portadora da missão de promover o desenvolvimento ("se encontra na vanguarda do processo de industrialização do país”), deixando assim claro de que é o desenvolvimento econômico, mais que questões de ordem política ou sociais seu principal mote (JAGUARIBE, 1956a, p. 60).

\section{O debate nacionalista}

Debate presente no livro $O$ nacionalismo na atualidade brasileira, tem o propósito de esclarecer o dilema do nacionalismo brasileiro ("ou alcança uma formulação mais consistente e suficientemente ou malogra desaparecendo a condição mesma do povo brasileiro realizar uma história nacional") em favor da adoção de políticas racionais e eficientes (JAGUARIBE, 1958b, p. 14). Conforme o autor, o surto de desenvolvimento processado a partir da 
Primeira Guerra Mundial, e acelerado com a depressão de 1929 e a Segunda Guerra Mundial, fez o país voltar-se a si mesmo, passando a produzir para o mercado interno. Como resultado, tornou-se necessário a integração do país como um todo, do que resultou novos movimentos nacionalistas.

Nascidos "fragmentária e descontinuamente, em função das áreas de integração constituídas pelo desenvolvimento econômico-social" ${ }^{11}$, segundo Jaguaribe, estão diretamente ligados à crescente importância que adquiriram no país as forças ligadas ao desenvolvimento econômico - "aspiram a um dirigismo racional, que favoreça a industrialização, por meio de medidas protecionistas e de processos de transferência de renda" (JAGUARIBE, 1958 b, p. 33). Compreendendo grupos que acusam "os mais elementares e os mais elaborados níveis de mentalidade e cultura" - burguesia industrial, proletariado, quadros técnicos e administrativos e a intelligentsia da classe média, - partilham da "convicção de que o país se transforma e se desenvolve a uma taxa extremamente favorável e dispóe de condiçôes para se tornar rapidamente uma grande nação". Trata-se, pois de uma outra orientação nacionalista, não xenófoba, que visa acelerar e racionalizar o processo de desenvolvimento (JAGUARIBE, 1958b, p. 36).

Retomando o debate acerca dos pontos que estrangulam o desenvolvimento brasileiro, Jaguaribe é taxativo: “as contradições que embaraçam o desenvolvimento no Brasil encontram-se na forma pela qual se entende ou pratica o nacionalismo, e não nas tendências gerais que o determinam e nos fins gerais a que propende" (JAGUARIBE, 1958b, 48). Introduz aí polêmica tese que pressupóe o nacionalismo como "um meio para se atingir um fim: o desenvolvimento"12 (JAGUARIBE, 1958b, p. 14).

Segundo Jaguaribe, o que torna uma política nacionalista não é "o fato de serem nacionais os agentes ou recursos empregados”, mas por representar a forma capaz de "assegurar a mais eficiente exploração" e produção de determinado bem, estar integrado com os problemas globais da nacionalidade e por ser capaz de transformar nossas estruturas tradicionais (JAGUARIBE, 1958b, p. 53). Advoga aí "uma atuação cultural e política que reajuste o movimento nacionalista aos imperativos do desenvolvimento, fim imediato que o suscita e orienta” (JAGUARIBE, 1958b, p. 48).

Superando a visão mecânico-formal em favor de uma perspectiva histórico-dialética, o autor reconhece como modelo econômico conveniente para o país:

(...) aquele que tire o máximo partido da especialização do país, no quadro da divisão internacional do trabalho, compatível com o máximo incremento de sua produtividade, mediante a mais acelerada possível transformação de sua estrutura econômico-social e a mais alta taxa possível de acumulação capitalista (JAGUARIBE, 1958b, p. 61). 
Para Jaguaribe, tal modelo possibilita o "reaparelhamento, reorganização e expansão dos bens e serviços de infraestrutura, a racionalização da agricultura, a industrialização acelerada”, visando à substituição de importaçôes e à expansão da indústria de base (JAGUARIBE, 1958b, p. 61). Estas, por sua vez, só podem ser alcançadas nas seguintes condições:

a) utilização ótima da capacidade de exportar por meio de um câmbio realista, da ampliação dos mercados e do melhoramento dos produtos; b) seleção das importaçôes em função de sua essencialidade, mediante um sistema tarifário apropriado, que se apoie em um sistema de ágios cambiais; c) máximo aproveitamento dos recursos naturais existentes, até o limite de sua marginalidade, fixado em função da oferta internacional e de nossa capacidade de importar; d) máxima compressão do consumo, particularmente do conspícuo, mediante uma política realista de salários e tarifas e de uma adequada política fiscal; e) ótima utilização da capacidade nacional de investimento, inclusive do capital estrangeiro que possa ser absorvido pelo país, e máximo incremento de nossa taxa de acumulação de capital, mediante política fiscal e creditícia global (JAGUARIBE, 1958b, p. 62).

Conquanto reafirme o caráter global do desenvolvimento, o exposto reflete um debate essencialmente econômico. Questóes políticas e sociais antes presentes em seu raciocínio são abandonadas em favor de um confronto entre nacionalismo e cosmopolitismo, em termos puramente econômicos. Provável reflexo da política econômica adotada pelo governo ${ }^{13}$ e do contexto de calmaria advindo com a posse de Juscelino Kubitschek.

\section{Por um desenvolvimento neobismarckiano ${ }^{14}$}

Essa terceira fase da produção de Jaguaribe é marcada pela transferência do foco de sua análise da questão do nacionalismo para um debate mais geral e melhor aquilatado sobre o desenvolvimento. Enquanto seus textos anteriores são cercados de um tom bastante panfletário, o livro Desenvolvimento econômico e desenvolvimento politico traz uma abordagem teórica do tema. Partindo da definição do que é desenvolvimento, passando pelos modos e condições à sua realização, o autor termina apresentando qual caminho, qual modelo de desenvolvimento a ser implantado no Brasil.

Segundo Jaguaribe, além de global, o desenvolvimento é um processo histórico-social que caminha para sua crescente racionalização. Uma vez que as condiçóes sobre as quais se processaram o desenvolvimento da Inglaterra e dos Estados Unidos são "historicamente quase irrepetíveis", a ideia de desenvolvimento espontâneo perdeu seu "caráter de necessidade lógica” tornando necessário o recurso da programação econômica (JAGUARIBE, 1968, p. 17). 
Entende-se por programação econômica, no sentido amplo do termo, a técnica de provocar a ocorrência de determinado resultado mediante uma intervenção deliberada no processo econômico, fundada no conceito racional deste e orientada de conformidade com um plano. Em sentido mais restrito entende-se por programação econômica uma política econômica, em geral do Estado, que vise a obter determinados resultados através da aplicação de planos apropriados (JAGUARIBE, 1968, p. 23).

Conforme o autor, "toda programação se realiza em duas etapas: a da preparação dos planos” - envolve a análise da situação, a escolha dos objetivos a alcançar e a determinação dos meios a serem utilizados - "e a de sua execução" - abrange aimplantação e operação de novos mecanismos legais e administrativos (JAGUARIBE, 1968, p. 25). Ainda que óbvias, para ele "tais etapas se revestem da maior importância para a determinação das condiçóes de eficácia de uma programação”. Faz então uma longa análise das condições à validade e vigência do plano antes de pôr-se a pensar seu problema central: quais "as condiçôes políticas de possibilidade da programação do desenvolvimento dos países subdesenvolvidos, notadamente dos latino-americanos”? (JAGUARIBE, 1968, p. 43).

Em primeiro lugar, tendo em vista que a forma de associação mais apropriada para o desenvolvimento de uma comunidade é a do Estado Nação, para Jaguaribe, impóem-se duas sérias consequências à programação do desenvolvimento (JAGUARIBE, 1968, p. 49). De um lado, "se torna cada vez mais inviável a promoção do desenvolvimento das pequenas naçôes subdesenvolvidas”, resultado de seu território exíguo somado à escassez de recursos naturais e ausência de mercado interno (JAGUARIBE, 1968, p. 50). De outro, "o desenvolvimento das grandes naçôes subdesenvolvidas tende a provocar a contradição com as condiçóes políticas e os requisitos econômicos para tal” (JAGUARIBE, 1968, p. 50). Ou melhor, há uma oposiçẫo entre a demanda por capital, que exige empréstimos externos, e a necessidade de afirmação nacional.

Se, para Jaguaribe, tal contradição pode ser resolvida a partir de um ajustamento de seu regime econômico "ao imperativo da preservação da autonomia nacional e na inflexível adoção de um sistema de poupança, de investimento e de produção que assegure a máxima taxa de desenvolvimento suportável pela comunidade", à primeira questão ele parece não enxergar saída (JAGUARIBE, 1968, p. 55). Por não serem capazes de formar um parque industrial, entende que são poucas as chances das pequenas naçóes romperem com a dependência em que se encontram das nações desenvolvidas. Permanecem, assim, como exportadoras de produtos primários e sofrem, por consequência, com o nacionalismo alheio. 
Ademais, Jaguaribe entende que os países subdesenvolvidos vivenciam uma crise social por efeito demonstração dos benefícios auferidos pelos países desenvolvidos com o welfare state e não por sua inviabilidade enquanto nação independente. Ou seja, embora suas condições reais sejam distintas das dos países atualmente desenvolvidos, suas condições ideais são as mesmas, porque presentes à mesma época. Isto posto, as massas dos países subdesenvolvidos aspiram aos benefícios do welfare state e desejam repartir as vantagens de um aumento de produtividade, embora ele ainda esteja em seu início. Como consequência, dá-se uma inversão do processo: "os benefícios do aumento da produtividade são repartidos por antecipação" privando os países subdesenvolvidos "de capacidade de investimento, mantendo-os, com isso na estagnação, ou "hipotecando-os ao investimento estrangeiro" (JAGUARIBE, 1968, p. 64).

Conforme o autor, a única forma de conter tais inconvenientes exige "viabilizar a contabilidade social e em face dela conduzir a comunidade a optar por certa taxa de consumo e poupança, rateando-se aquela e esta entre os estratos da sociedade” (JAGUARIBE, 1968, p. 67). Tal operação é, porém, controversa na medida em que há uma "propensão dos estratos inferiores da sociedade a melhorar seu regime de participação, em detrimento dos superiores e destes a manter e ampliar suas vantagens a expensas dos inferiores" (JAGUARIBE, 1968, p. 67). Para Jaguaribe, é justamente neste ponto que o debate se torna um debate político.

Quais caminhos ou modelos estão à disposição dos países subdesenvolvidos para atacarem a crise social e promoverem eficientemente seu desenvolvimento? O autor elenca três: o bismarckismo ou neobismarckismo, o capitalismo de Estado e o socialismo, relacionados "respectivamente, à predominância política da burguesia, das classes médias e à ocorrência de um conjunto especial de circunstâncias" (JAGUARIBE, 1968, p. 63). Vale aqui uma larga citação para entendermos detalhadamente como o autor caracteriza cada um desses modelos:

O bismarckismo (...) é o modelo político que permite ao chefe do governo o exercício de uma arbitragem entre as diversas camadas sociais, baseada numa contabilidade nacional objetiva, que assegure a maior capacidade possível de investimento tolerável pela comunidade, regulando a participação de cada camada de acordo com sua capacidade política de reivindicação e assegurando aos empresários nacionais a liderança na promoção de desenvolvimento da (...) nação, de acordo com o programa traçado pelo Estado. O capitalismo de Estado é o modelo político que consiste em superar a crise social pela transferência dos empreendimentos privados para o Estado, da iniciativa e do controle, e pelo nivelamento acentuado da capacidade de consumo de todos os grupos sociais e indivíduos 
(...). Finalmente o socialismo desenvolvimentista (...) corresponde a uma forma mais radical de capitalismo de Estado, que socializa os meios de produção e suprime a economia de mercado (JAGUARIBE, 1968, p. 63 e 65)

A isso acrescenta: "o conteúdo democrático dos regimes dedicados à promoção do desenvolvimento é determinado menos pelos ideais políticos dos protagonistas do que pelo grau de compatibilidade entre os objetivos perseguidos e a livre iniciativa dos agentes"; exemplo claro da predominância do desenvolvimento à questão política e social em seu raciocínio (JAGUARIBE, 1968, p. 64).

Não obstante isso, Jaguaribe destaca que a possibilidade da programação do desenvolvimento depende da "possibilidade de o poder público proceder, consistentemente, à elaboração e execução do plano", superar a crise política, compatibilizar a validez do plano e a vigência do processo do poder, ser "representativo das expectativas sociais" (JAGUARIBE, 1968, p. 69). Uma vez que é exatamente o grau de representatividade que determina o grau de eficácia que a programação para o desenvolvimento tende a obter, deparamo-nos com um círculo vicioso: quanto menos desenvolvida a comunidade, mais ela necessita programar seu desenvolvimento, porém "menos provável será a implementação coerente dos planos adotados, tendo em vista a efetividade puramente temporária do poder" (JAGUARIBE, 1968, p. 72). No caso brasileiro, a despeito de possuirmos um regime representativo, inexiste qualquer mediação política entre os cidadãos e seus representantes, há um intervalo entre vigência e validez do poder.

Como fugir a este círculo vicioso? Conforme o autor, "as alternativas possíveis que se abrem para a superação dos óbices políticos ao desenvolvimento são, igualmente, determinadas pela forma segundo a qual a comunidade logra superar sua crise social”; ou seja, se há predominância política da burguesia, das classes médias ou do conjunto especial de circunstâncias próprias ao socialismo (JAGUARIBE, 1968, p.78). A cada uma dessas alternativas Jaguaribe apresenta um modelo político específico, respectivamente: "o nacional-capitalismo, o capitalismo de Estado e o socialismo desenvolvimentista" (JAGUARIBE, 1968, p. 78). Modelos com "significação e alcance globais”, dependem da situação em que se encontra a comunidade nos planos econômico e cultural.

Qual caminho cabível ao Brasil? Sua resposta deixa entrever o amadurecimento do seu raciocínio, bem como o esforço em afastar qualquer alternativa golpista. Para o autor, na medida em que nos encontramos entre os países com razoável nível de desenvolvimento econômico, que atingiram ou se encaminham para atingir razoável nível de diferenciação econômica, e contamos com uma burguesia empresarial dinâmica e poderosa, o modelo 
político mais apropriado para o seu desenvolvimento é o nacionalcapitalismo (o bismarckianismo), por intermédio de um partido do desenvolvimento" (JAGUARIBE, 1968, p. 180). Comprometido com os interesses do empresariado e das massas, este partido é responsável por formular "uma ideologia desenvolvimentista nacional-capitalista, orientada para os grandes investimentos públicos e de base, para a produtividade do capital e do trabalho e, para a consolidação e o engrandecimento da nação" (JAGUARIBE, 1968, p. 79). Investindo contra as formas pré-capitalistas de economia em favor da equalização das oportunidades e do "máximo de bem-estar social compatível com as necessidades de investimento produtivo", tal modelo demanda uma liderança de tipo neobismarckiano (JAGUARIBE, 1968, p. 79). Justamente o que teria representado o governo e a figura de Juscelino Kubistchek.

Para Jaguaribe, "a aliança PSD-PTB representou, de certa forma, esse partido do desenvolvimento, assim com a Presidência Kubitschek manifestou características neobismarckianas” (JAGUARIBE, 1968, p. 101). Responsável por instaurar o Plano de Metas - "esforço de programação do desenvolvimento do país orientado no sentido de criar ou expandir a oferta de bens e serviços de infraestrutura e de base", - consolidou "o maior esforço de desenvolvimento econômico empreendido no Ocidente por um país subdesenvolvido" (JAGUARIBE, 1968, p. 180). Sem contar com apoio de qualquer entidade internacional, antes as contrariando, conforme o autor, o governo JK teve "extraordinário êxito em seu esforço de desenvolvimento, atingindo e ultrapassando quase todas as metas" (JAGUARIBE, 1968, p. 180). Mais à frente conclui: "ao que tudo indica foi vencida a barreira do desenvolvimento e o país projetado em processo de continuado crescimento" (JAGUARIBE, 1968, p. 181).

É, pois, visível o otimismo do autor. Mesmo no último capítulo do livro, quando analisa alguns problemas do desenvolvimento logrado pelo governo $\mathrm{JK}^{15}$, - Jaguaribe conclui:

[As] experiências e decisões dos últimos dez anos configuram uma doutrina e uma prática brasileiras do Estado, da economia, da programação e da democracia social. Essa doutrina e essa prática (...) apontam, inequivocamente, para certa direção: uma democracia social e nacional, programadamente orientada para o desenvolvimento, o bem-estar social e a crescente igualização das oportunidades, entre setores, regióes e pessoas, onde a propriedade privada dos meios de produção e a gestão privada dos empreendimentos são preservados na medida em que representem condições de eficiência econômica, onde o capital público tem a principal responsabilidade pela manutenção da taxa de investimentos, mas a gestão dos empreendimentos, ainda que públicos, tende a ser exercida de forma profissional, segundo critério e produtividade (JAGUARIBE, 1968, p. 213). 
Consagrando o que denomina nacional-desenvolvimentismo - corrente ideológica que pressupõe "a promoção do desenvolvimento e a consolidação da nacionalidade, dois aspectos correlatos do mesmo processo emancipatório", - teria como principal contribuição promover a decolagem econômica do Brasil (JAGUARIBE, 1968, p. 208).

Novamente, o autor parece associar a promoção do desenvolvimento econômico não só à resolução da crise nacional, mas à consolidação mesmo da democracia. Para Jaguaribe, por programar e executar "satisfatoriamente" tal programação, o governo JK deu um importante passo em sentido ao desenvolvimento da economia nacional e, por consequência (até porque o desenvolvimento seria global), à melhoria do país como um todo.

\section{A GUISA DE CONCLUSÃO: O SENTIDO DO PRIMEIRO MOMENTO DE HÉLIO JAGUARIBE}

O aqui exposto permite vislumbrar o importante peso que o contexto histórico exerceu sobre as formulaçóes iniciais de Hélio Jaguaribe. Como já dito, não obstante o móvel do seu pensamento ter sido sempre a promoção do desenvolvimento econômico, a conjuntura dos anos 1950 colocou em pauta questôes de ordem política e social não só no Brasil, mas em todo mundo. Isso explica porque seus primeiros trabalhos trazem um debate muito mais dilatado (sobretudo no que tange aos movimentos políticos processados entre 1953 e 1956) que os últimos. A nosso ver, à medida que tais litígios foram se resolvendo, se tornando menos explosivos, pôde o autor debruçar mais diretamente sobre a temática do desenvolvimento. Em outras palavras: o contexto de calmaria advindo da posse de Juscelino Kubitscheck, somado ao lançamento do Plano de Metas em 1956, permitiu que Jaguaribe focalizasse sua análise nas medidas necessárias à consolidação do desenvolvimento. Daí os dois textos escritos após 1957, aqui analisados, trazerem uma análise muito mais restrita e técnica, consagrando, ao final, ideia de que uma vez promovido o desenvolvimento econômico, resolver-se-iam todos os problemas nacionais. São, pois os dilemas e desafios postos pelo contexto histórico específico que explicam o sentido da "evolução das ideias" de Jaguaribe.

Diferentemente, do que pressupóe muitos de seus críticos e do $\operatorname{ISEB}^{16}$, a nosso ver não se trata de uma opção deliberada deste para consagrar a dominação ideológica da burguesia, mas antes uma tentativa de responder a sua realidade objetiva. Vale lembrar que os dez anos que transcorreram entre o suicídio de Vargas e o golpe militar caracterizaram "um momento de crise estrutural da sociedade brasileira” (MARTINS, 2008, p. 2). O debate político-intelectual girou quase que exclusivamente em torno das questóes do 
desenvolvimento e do projeto de desenvolvimento não só no Brasil, mas em toda a América Latina.

Dentro desse quadro os estudos realizados pela CEPAL e, no caso específico do Brasil, pelo BNDE, ganharam estatuto científico, assumindo grande importância "nas definições ideológicas, na articulação das relações de forças do período", embora ainda tratasse de um debate puramente econômico, cujo objetivo principal era a industrialização (CARDOSO, 1975, p. 385). Somente no final dos anos 50 e 60 é que os fatores sociais (disparidade de ingresso no desenvolvimento, inflação, desigualdade) passaram a ser decisivos. Até lá o nacionalismo despontou como paradigma do desenvolvimento e o planejamento, até então restrito a uma elite estatal, passou a envolver quadros da sociedade civil e se orientar para dentro do aparelho de Estado. Isso explica a criação de diversas instituições no período (dentre elas o próprio ISEB), quer para a formação de quadros técnicos especializados ao exercício de determinadas atividades, quer para aprofundar os estudos dos problemas nacionais, racionalizar o Estado.

No Brasil essa agenda atingiu seu auge entre os anos 1956-1961, precisamente os anos do governo JK. De fato, o lançamento do Plano de Metas consagrou a incorporação da ideologia desenvolvimentista "à retórica oficial do governo" (BIELSCHIWSKY, 2004, p. 404). Era hora de implantar políticas econômicas concretas, adotar políticas de proteção substituindo importações, aprofundar a industrialização, sobretudo a de base, planejar o desenvolvimento econômico já que processo global. É, pois, este caldo cultural que explica porque, mesmo em face de uma arguta análise da situação brasileira, tocando desde questóes econômicas a sociais e políticas Jaguaribe limitou-se, ao final, a prescrever medidas econômicas.

A nosso ver, longe de um conservadorismo, isso expressa a crença do autor na industrialização como processo transformador. A associação, bastante comum na época, entre as ideias de desenvolvimento e industrialização com a de progresso. É importante lembrar que se tratava de uma atmosfera de aparente euforia ${ }^{17}$, resultado dos altos índices de crescimento econômico alcançados pelo país, em que a perspectiva desenvolvimentista possuía como que 'validade universal'.

Nesse sentido, Hélio Jaguaribe foi sim responsável por um diagnóstico bastante crítico da realidade brasileira no que tange aos fatos e movimentos políticos processados entre os anos de 1953 e 1956. Denunciando o baixo índice de renovação das elites dirigentes e o conteúdo reacionário e antinacional de que as mesmas se revestiam, bradou por uma aliança entre as classes progressistas, capaz de realizar "os pontos básicos de uma política pela emancipação nacional” (JAGUARIBE, 1955c, p. 49). Ao conclamar à burguesia 
industrial e a intelligentsia para a realização imediata de um trabalho ideológico no país, o fez por acreditar ser este um veículo à conscientização da classe média e do proletariado.

É importante, porém lembrar que se nos anos 1950 a agenda temática dos anos 1950 girou, quase que exclusivamente, em torno dos questionamentos sobre o atraso e sobre as possibilidades de desenvolvimento da sociedade brasileira, ao final desta década os efeitos perversos do nacional-desenvolvimentismo - crise econômica e social expressa nas implicaçóes da migração campo-cidade, aumento das taxas de inflação, reafirmação das desigualdades regionais e sociais e pressão do balanço de pagamentos - fizeram desvanecer o otimismo com o nacional-desenvolvimentismo. Tanto o desenvolvimentismo de JK foi revisto e questionado, como se processou um reexame das teses marxistas, uma renovação da esquerda no Brasil. Conceitos como classe, conflito social, revolução social passaram aí a integrar grande parte das interpretaçóes progressistas do momento, incluindo as da última fase do ISEB ${ }^{18}$.

Jaguaribe, por sua vez, não apenas manteve como aprofundou seu economicismo. Se no livro de 1958, ao repensar o nacional-desenvolvimentismo o autor priorizou o segundo ao primeiro, em claro compasso com a política econômica então vigente, no texto de 1962, relançado (sem grandes alterações) em 1968, o autor aparentemente ignorou o novo contexto. Jaguaribe estava então imerso num ambiente de profunda instabilidade política e de queda do PNB (Produto Nacional Bruto), que dava a entender que a longa fase de crescimento chegara ao seu fim.

Conquanto patente que o modelo de desenvolvimento até então processado não fora capaz de superar as desigualdades (era antes concentrador de renda), bem como aprofundara a situação de dependência do país, Jaguaribe insistiu em investigar as condições políticas e sociais necessárias à satisfatória programação do desenvolvimento econômico. Ao, em 1962, ainda crer que o desenvolvimento econômico era a questão chave do seu tempo, porta de entrada a transformações políticas e sociais, e reiterar ademanda pela formulação de uma ideologia desenvolvimentista, o autor ignorou as mudanças de contexto. Recusou-se a ver os limites do desenvolvimentismo, a nova estrutura social, a luta de classes que então despontava, insistindo em clamar por uma liderança de tipo neobismarckiano. Perde o bonde da história, consagrando, ao final, uma perspectiva no mínimo técnica.

Logo, se nos anos 1950 é a correspondência de suas ideias com o contexto do seu tempo que confere ao pensamento de Hélio Jaguaribe um caráter progressista, nos anos 1960 é justamente por dissociar-se deste, ignorando o que a história revelara, que seu pensamento se mostra conservador. 


\section{Notas}

${ }^{1}$ Bresser-Pereira (2000, p. 237) distingue três momentos na obra de Hélio Jaguaribe: o momento do desenvolvimento, nos anos 1940 e 1950; "o momento da democracia ou da liberdade, quando nos anos 1970, a redemocratização do país torna-se a meta principal a ser atingida; e o momento da social democracia ou igualdade, quando recuperando a liberdade, coloca-se o problema das igualdades, não apenas jurídica, mas real".

${ }^{2}$ Me refiro aí aos intelectuais que integravam o ISEB. Nascido inicialmente como Instituto Brasileiro de Sociologia e Política (IBESP), reunido em torno dos intelectuais mormente cariocas, transforma-se em julho de 1955 no Instituto Superior de Estudos Brasileiros, órgão financiado pelo Ministério da Educação e Cultura. Tinha a função formal de promover cursos avulsos, conferências e publicações, ao passo que se pretendia um laboratório de pesquisa da realidade brasileira.

${ }^{3}$ É importante destacar que recepção das ideias mannheimianas pelos intelectuais brasileiros significou atribuir um papel histórico às ciências, sobretudo à sociologia, no sentido de distinguir tendências tradicionais e modernas. "Acreditava-se na necessidade de influir/ intervir nas mais diversas esferas da vida social, no sentido de torná-las mais modernas, racionais e rentáveis" (VILLAS BOAS, 2002, p. 138).

${ }^{4}$ Revista editada pelo IBESP (Instituto Brasileiro de Economia, Sociologia e Política) entre 1953 e 1956, publicava os textos de seus encontros e discussões. Combinando artigos de interpretação econômica, sociológica, política e cultural do Brasil com a análise dos fenômenos do seu tempo acabou por consolidar um amplo diagnóstico do país, mesmo contando com apenas com cinco números.

Faz-se importante destacar que em muitos dos artigos desta revista a autoria não está declarada, o autor não é identificado pois, como aponta Cristina Buarque de Hollanda, os Cadernos consistiam em uma produção coletiva, "autores e indivíduos diluem-se em projeto coletivo" do IBESP (HOLLANDA, 2012, p. 610). Ainda assim, pelo linguajar, termos e temas utilizados, combinado ao fato de ser Hélio Jaguaribe o editor da revista, pode-se "com alguma segurança" atribuir-lhe a autoria de determinados textos tais como editorial / apresentação e estudos. Os artigos em que essa autoria está subentendida e não declarada têm o título seguido de um asterisco $\left(^{*}\right)$ na bibliografia.

${ }^{5}$ Vivenciava-se aí um contexto de reconstrução do capitalismo mundial dentro de um quadro de Guerra Fria, pautado na crise do liberalismo e na ascensão do keynesianismo, assim como relativo afrouxamento do regime soviético após a morte de Stalin em 1953.

${ }^{6}$ Jaguaribe bebe aí das teses consagradas no Manifesto de Prebisch de 1949 que, recusando as teses da teoria ortodoxa, aponta para a disparidade de condições a partir das quais os países centrais e periféricos se inserem no mercado internacional.

${ }^{7}$ Embora citado aqui, é somente no livro Condições institucionais ao desenvolvimento que Jaguaribe deixa claro o que entende por política de clientela. Conforme o autor, trata-se da política surgida com a urbanização brasileira responsável por gerar uma nova classe: a classe média. Uma vez que o processo produtivo brasileiro apresentava uma relação de classes bastante simples - resumia-se em classe dominante dos fazendeiros e/ou burguesia mercantil e classe dominada do campesinato, - esta classe estava deslocada do processo produtivo. Isto fez com que se organizassem clientelas em torno das fazendas, sendo posteriormente consolidadas e homologadas pelo regime federativo via prática do voto de favor, barganhado pelo emprego de favor (JAGUARIBE, 1958).

${ }^{8}$ Aqui também falta uma explicação do que seria o Estado Cartorial. Em Condições institucionais de desenvolvimento Jaguaribe afirma: o Estado Cartorial é "produto da política de clientela e, ao mesmo tempo, o instrumento que a exerce e a conserva" por meio do oferecimento de cargos no serviço público. Ao subsidiar as clientelas e envolver a classe média marginal, converte-se em uma "pirâmide infinita de cargos" cuja única função é se auto sustentar através da arrecadação (JAGUARIBE, 1958, p. 22).

${ }^{9}$ Refere-se aí aos movimentos que se constituem sob a bandeira da recuperação moral da política, , o suicídio de Vargas em 1954 e eleição de Juscelino Kubitschek em1955. Vale lembrar que o ano de 1954 até a posse de Juscelino em 1956 foi um período de grande instabilidade política no país. Nesse curto período alternaram-se campanha moralista, reação popular ao suicídio de Getúlio Vargas e tentativas de golpe de Estado por setores das Forças Armada e UDN de modo a inviabilizar a posso dos candidatos eleitos (Juscelino Kubistchek e João Goulart).

Conforme o autor o moralismo tratou de um movimento tipicamente da pequena burguesia. Produto da situação econômica do país (desvalorização dos ordenados e aumento do custo de vida) somado à política praticada por Vargas, apontava para a inautenticidade do governo sem, porém, aprofundar até suas causas e condições. (JAGUARIBE, 1954d, p. 06). O Golpe de Agosto (deposição e consequente suicídio de Vargas) expressaria a crise dessa pequena burguesia que, "tendo perdido a possibilidade de dar uma solução própria ao processo político-social do país, aderiu à ideologia e submeteu-se à liderança da burguesia mercantil" (JAGUARIBE, 1955C, p. 34). Por fim, a eleição presidencial de 1956 assinalou um 
retorno às linhas mestras do quadro político-social do governo Vargas, com a diferença de que o debate, agora, se transferiu para o plano "ideológico programático" (JAGUARIBE, 1955a, p. 06).

10 Tais fases correspondem, respectivamente, aos seguintes contextos: 1) início do governo JK acompanhado de certo apaziguamento das forças em disputa; lançamento do Plano de Metas seguido da instauração da administração paralela fundamental à execução do mesmo; 2) auge das conquistas do Plano de Metas, consolidando nacionalmente a opção pelo desenvolvimento associado; 3) final do governo JK até o início do governo Jango; quadro econômico de inflação crescente, acompanhado do aumento das tensões sociais e políticas (CPDOC, s/d).

${ }^{11}$ Conforme o autor, temos um nacionalismo cultural ligado ao movimento modernista, um econômico expresso no movimento"o Petróleo é nosso", e outro político identificado com as exigências de democracia e justiça social internamente e com a adoção de uma linha neutralista externamente (JAGUARIBE, 1958b).

${ }^{12}$ É importante destacar que foi a publicação desse livro que levou à crise do ISEB e consequente saída de Jaguaribe do instituto. Considerado um "livro dos trustes estrangeiros", por opor nacionalismo de meios ao nacionalismo de fins e legitimar a utilização de capital estrangeiro à promoção do desenvolvimento nacional, tornou patente a divisão do instituto entre os partidários de um "ISEB acadêmico" e aqueles favoráveis a um "ISEB mais ativista" (PEREIRA, 2002, p. 153).

${ }^{13} \mathrm{O}$ governo Kubitscheck foi marcado por grandes projetos, principalmente no que se refere à industrialização. Procurando atrair tecnologia e capital, JK eliminou barreiras protecionistas oferecendo vantagens (reserva de mercado para seus produtos, facilidade de remessa de lucros para o exterior, baixa tributação da importação de maquinário industrial) a multinacionais que desejassem se instalar no país, principalmente indústrias de bens de consumo (destaque para a indústria automobilística). Além disso a aliança entre o PSD e PTB dois dos maiores partidos políticos do Brasil garantiu-lhe estabilidade política necessária: atendia as expectativas da elite agrária ao mesmo tempo em que ampliava o mercado de trabalho nas áreas urbanas.

${ }^{14}$ Sistema Bismarckiano é o nome que se dá para a política externa do chanceler alemão Otto von Bismarck entre 1871 e 1890 que culminou na fundação do Império Alemão. Procurando manter a estabilidade social e o progresso, Bismarck consolidou uma espécie de reformismo conservador cujo Executivo forte tinha capacidade de aglutinar as classes sociais. Nesse sentido, "desenvolvimento bismarckiano" expressa o desenvolvimento engendrado através do condicionamento da economia pelo Estado sob várias maneiras de dirigismo.

Hélio Jaguaribe, por sua vez, utiliza o termo bismarckianismo para diferenciar "desenvolvimento espontâneo" de "desenvolvimento programado". Por entender que historicamente o desenvolvimento programado como característica básica do processo histórico dos países subdesenvolvidos, essencialmente após a Segunda Guerra Mundial, pressupõe como "neobismarckiano" todo desenvolvimento que utilize da racionalidade técnica (seja em regimes autoritários ou democráticos, socialistas ou liberais) e da arbitragem do Estado no processo real de desenvolvimento político e social. Logo, é o esforço do Estado em planejar e em mediar as diferentes forças e classes sociais em sentido ao desenvolvimento econômico que o torna o bismarckiano (SILVA, 2005).

15 Tais como o fato de este não se manifestar de forma homogênea em todos os setores da economia ou nas diferentes regiões do país; aprofundar "a falta de representatividade das agências e dos processos políticos"; agravar a "falha de autenticidade e de funcionalidade dos órgãos do Estado e de seu atos"(JAGUARIBE, 1968, p. 192)

${ }^{16}$ Refiro-me aqui às críticas de Caio Navarro Toledo (1982) e Maria Sylvia Carvalho Franco (1978) que pressupõem o ISEB enquanto responsável por forjar uma ideologia, a ideologia do desenvolvimento econômico-social. Segundo eles, por silenciar sobre as relações de produção, os conflitos de classe, em favor do conflito classe produtiva versus improdutiva, Nação versus antinação Jaguaribe e o ISEB propagaram a ilusão de que os benefícios do desenvolvimento se repartiriam de forma igual pela sociedade. Consagraram, ao final, "a dominação ideológica da burguesia moderna", a realização da hegemonia econômica e política da burguesia industrial (FRANCO, 1978, p. 197).

De modo semelhante, e referindo ao pensamento de Hélio Jaguaribe, Octavio lanni entende que o que se buscava com o modelo do neobismarckianismo ou nacional- desenvolvimentismo era "o desenvolvimento acelerado do capital privado nacional e estrangeiro". Isso, por sua vez, significou o comprometimento crescente do Estado com o capital monopolista, com as forças burguesas e conservadoras nacionais o que teria criado condições para o Golpe militar de 1964 (IANNI, 1984, p. 61).

${ }_{17}$ Utilizamos a palavra aparente, pois já em 1958 observava-se o agravamento da situação inflacionária (de 7\% em 1956, pula para 24,3\% em 1958), consequência direta das estratégias de financiamento do ambicioso Plano de Metas - teve como principais fontes: o capital estrangeiro atraído por uma política cambial favorável, o que agravava ainda mais a situação do balanço de pagamentos nacional, e os investimentos públicos obtidos a partir da emissão de papel-moeda. 


\begin{abstract}
${ }^{18}$ Ao longo dos nove anos de existência de ISEB é possível distinguir três fases: uma primeira de 1955 a 1958 sob orientação de Hélio Jaguaribe, uma segunda de 1959 a 1962 sob a direção pessoal de Roland Corbisier, e a última de 1962 até o fechamento do instituto em 1964, quando a figura de Álvaro Vieira Pinto ganha destaque. Conforme Toledo, enquanto a primeira fase "se caracteriza pela manifestação de posições ideológicas extremamente ecléticas e conflitantes", a segunda "corresponderia àquele [momento] onde a ideologia nacional-desenvolvimentista é hegemônica no interior do ISEB" e a terceira ao "movimento político pelas Reformas de Base" (1982, p. 187. Grifos no original).
\end{abstract}

\section{Referências}

BIELSCHOWSKY, R. Pensamento econômico brasileiro: o ciclo ideológico do desenvolvimentismo. Rio de Janeiro: Contraponto, 2000.

BITTENCOURT, A. 2011. O Brasil e suas diferenças: uma leitura genética de Populações meridionais do Brasil.171 f.Dissertação (Mestrado em Ciências Sociais) -IFCS, UFRJ, Rio de Janeiro.

BRESSER PEREIRA, L.C. Os três momentos de Hélio Jaguaribe. In: VENANCIO FILHO, A. (org). Estudos em homenagem a Hélio Jaguaribe. São Paulo: Paz e Terra, 2000.

CARDOSO, M.L. Ideologia do desenvolvimento. Brasil: JK-JQ. Rio de Janeiro: Paz e Terra, 1975.

DRAIBE, S. Rumos e metamorfoses. Estado e industrialização no Brasil 1930/1960.Rio de Janeiro: Paz e Terra.1985.

FRANCO, M.S.C. O tempo das ilusões. In: CHAUI, M. (org). Ideologia e mobilização popular. Rio de Janeiro: Paz e Terra, 1978.

BUARQUE HOLLANDA, C. Os Cadernos do Nosso Tempo e o interesse nacional. Dados, Rio de Janeiro, vol. 55, n³, pp. 607-640, 2012.

JAGUARIBE, H. Que é filosofia? Revista brasileira de Filosofia, n. 1, pp, 165-181,1951.

JAGUARIBE, H. Apresentação. Cadernos do Nosso Tempo, n.1, pp. 1-2, 1953a.

JAGUARIBE, H.. A crise brasileira. Cadernos do Nosso Tempo, n. 1, pp. 120-160, 1953b.

JAGUARIBE, H. A crise do nosso tempo e do Brasil*. Cadernos do Nosso Tempo, $\mathrm{n}^{\circ} 2$, pp.01-17, 1954a.
JAGUARIBE, H. O legado político de Vargas e as possibilidades de sua potencialização ideológica. Cadernos do Nosso Tempo, n. 3, pp. 49-56, 1955a.

JAGUARIBE, H. Situação política brasileira. Cadernos do Nosso Tempo, n. 2, pp.101-122, 1954b.

JAGUARIBE, H. A Crise da Universidade. Revista brasileira de Filosofia, n. 4, pp 16-34. 1954c.

JAGUARIBE, H. A sucessão presidencial. Cadernos do Nosso Tempo, n. 4, pp. 01-23, 1955a.

JAGUARIBE, H. Situação atual do Brasil. Revista do Clube Militar, n. 135, pp. 5-12, 1955b.

JAGUARIBE, H. Para uma política nacional de desenvolvimento.Cadernos do Nosso Tempo, n. 5, 47-188. pp. 1956a.

JAGUARIBE, H. O problema do desenvolvimento econômico e a burguesia nacional. São Paulo: Coleção Fórum Roberto Simonsen, 1956b.

JAGUARIBE, H. A filosofia no Brasil. Rio de Janeiro: ISEB, 1957.

JAGUARIBE, H. Condições institucionais ao desenvolvimento. Rio de Janeiro: ISEB, 1958a.

JAGUARIBE, H. O nacionalismo na atualidade brasileira. Rio de Janeiro: ISEB, 1958b.

JAGUARIBE, $H$. Sucinta análise do nacionalismo brasileiro.Revista do Clube Militar, n. 147, pp. 11-14, 1959.

JAGUARIBE, H. Desenvolvimento econômico e desenvolvimento político. Rio de Janeiro: Fundo de Cultura, 1962. 
JAGUARIBE, H. Desenvolvimento econômico e desenvolvimento político. Rio de Janeiro: Paz e Terra, 1968.

JAGUARIBE, H. Breve notícia sobre a própria obra. VENANCIO FILHO (org). Estudos em homenagem a Hélio Jaguaribe. São Paulo: Paz e Terra, 2000.

LAFFER, C. Uma análise da trajetória e do perfil intelectual de Hélio Jaguaribe. In: VENANCIO FILHO, A. (org). Estudos em homenagem a Hélio Jaguaribe. São Paulo: Paz e Terra, 2000.

MARTINS, T. G. 2008. Florestan Fernandes e Guerreiro Ramos: para além de um debate.
230 f.Tese de doutorado (Doutorado em Sociologia) - IFCH, Unicamp, Campinas.

PAIVA, V. Paulo Freire e o nacionalismo desenvolvimentista. Rio de Janeiro: Civilização brasileira.1980.

PEREIRA, A. E. O ISEB na perspectiva do seu tempo. Tese (Doutorado em Ciência Política)- FFLCH, USP, São Paulo, 2002.

TOLEDO, C. N. ISEB: Fábrica de Ideologias. São Paulo: Ática, 1982.

VENANCIO FILHO, A (org). Estudos em homenagem a Hélio Jaguaribe. São Paulo: Paz e Terra, 2000.

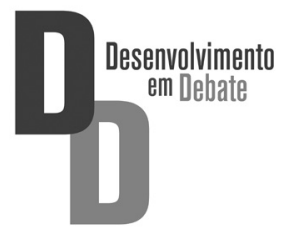




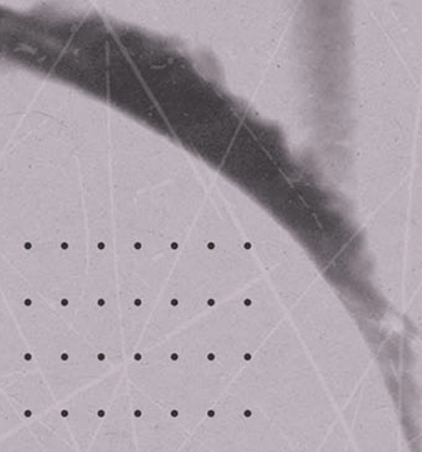

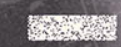
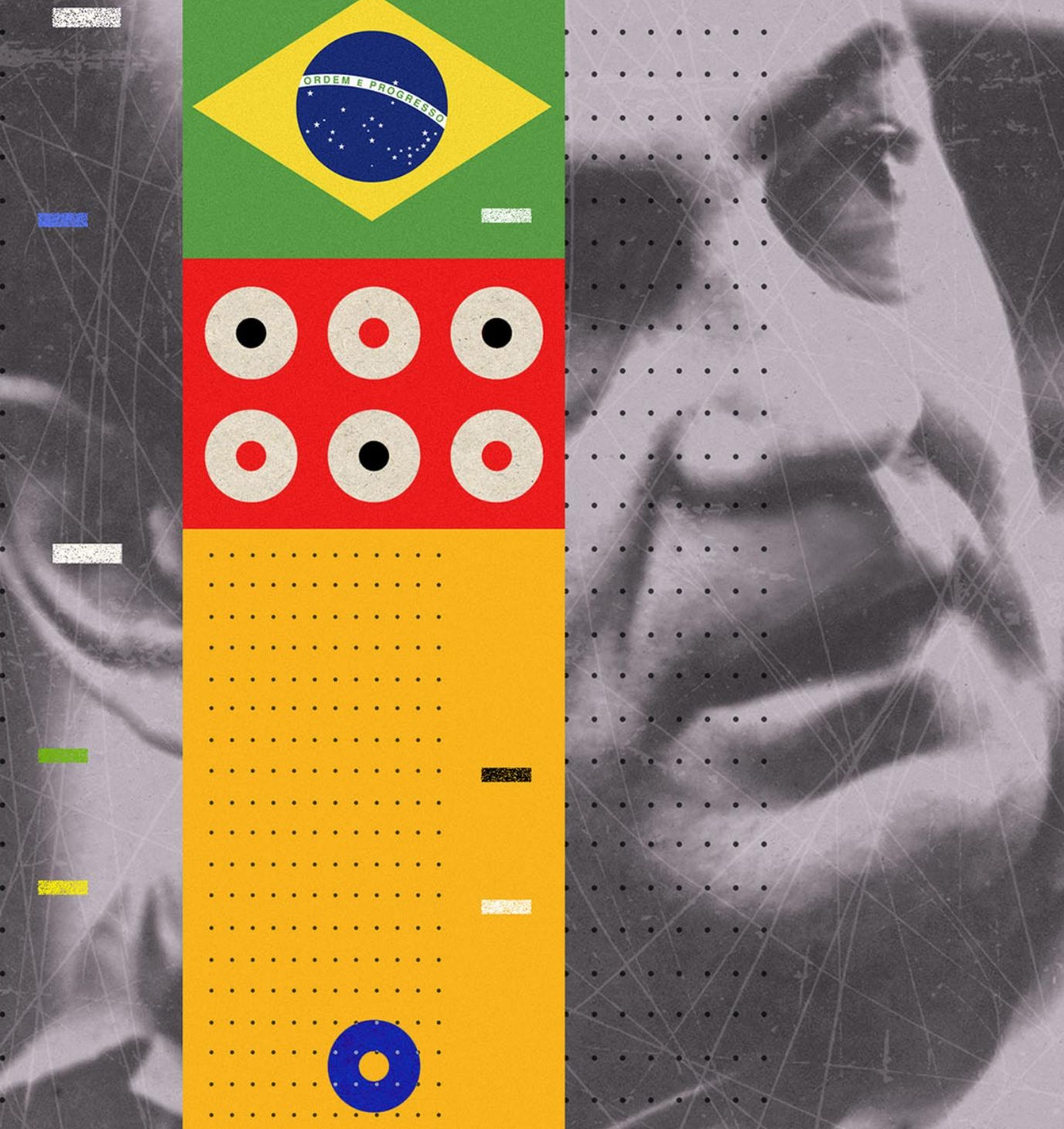


\title{
O nacional-desenvolvimentismo de Hélio Jaguaribe: nacionalismo, ideologia e classes sociais
}

\author{
The national-developmentalism of \\ Hélio Jaguaribe: nationalism, ideology \\ and social classes
}

\author{
Helio Cannone* | Hugo Müller**
}

\begin{abstract}
Resumo
$\mathrm{O}$ artigo pretende-se um esforço de intepretação da produção do cientista político Hélio Jaguatibe, tendo como foco o período em que atuou no Instituto Superior de Estudos Brasileiros (ISEB). A partir de metodologia contextualista, pretendemos inserir as ideias do autor em sua época para entender quais eram os problemas que ele se deparava e, assim, melhor compreender sua inserção nestes debates. A partir de obras escritas nos anos 1950, serão privilegiadas suas ideias acerca do nacional-desenvolvimentismo, papel do nacionalismo no Brasil e sua interpretação sobre Ideologia, classe sociais e democracia no país.
\end{abstract}

Palavras-chave:nacional-desenvolvimentismo;ISEB; burguesia nacional; nacionalismo; ideologias políticas.

\begin{abstract}
The article intends to try to interpret the production of political scientist Hélio Jaguatibe, focusing on the period in which he worked at Superior Institute of Brazilian Studies (ISEB). Based on contextual methodology, we intend to insert the author's ideas in his time to understand what were the problems he faced and, thus, better understand his insertion in these debates. From works written in the 1950s, his ideas about national developmentalism, the role of nationalism in Brazil and his interpretation of ideology, social class and democracy in the country will be privileged.
\end{abstract}

Keywords: national-developmentalism; ISEB; national bourgeoisie; nationalism; political ideologies

\footnotetext{
* Candidato a Doutor em Ciência Política, Institiuto de Estudos Sociais e Políticos, Universidade do Estado do Rio de Janeiro, RJ, Brasil. https://orcid.org/0000-0002-8774-4197. E-mail: helio.cannone@gmail.com

** Candidado a Doutor em História, Universidade do Estado do Rio de Janeiro, RJ, Brasil. https://orcid.org/0000-0002-9498-5685. E-mail: hugomuller.rj@gmail.com
} 


\section{INTRODUÇÃO}

Este trabalho consiste em um esforço de interpretação sobre o pensamento nacionalista de Hélio Jaguaribe. Serão discutidas as singularidades e as raízes do conceito de nacionalismo forjado por Hélio Jaguaribe, as aproximaçóes e divergências com outros intelectuais-públicos da época. Como recorte, os anos de Jaguaribe à frente do IBESP e do ISEB, ou seja, de 1952 a 1958, serão nossas balizas cronológicas. Identificamos neste período o ápice na História do Brasil da germinação projetos nacionalistas associados a ideia de desenvolvimento. $\mathrm{O}$ artigo se divide em quatro partes, após esta introdução, iremos apontar a pluralidade dos pensamentos nacional-desenvolvimentistas nos anos 50, inserindo a contribuição de Jaguaribe em contramão ao desenvolvimentismo de outros atores políticos eintelectuais do período. A fim de cumprir nosso objetivo, iremos ao longo do artigo expor nossas discordâncias com parte da bibliografia que compreende o isebiano enquanto um intelectual oficial do projeto desenvolvimentista do Governo JK. Na terceira parte, apresentaremos a concepção de nacionalismo por parte de Hélio Jaguaribe, sua relação com o conceito de desenvolvimento, além de estabelecer um panorama mais geral dos distintos nacionalismos na década de $1950 . \mathrm{Na}$ quarta parte, traremos à baila o alicerce do nacionalismo de Hélio Jaguaribe, sua concepção de história e ideologia e sua visão histórica de classes sociais no Brasil, será o momento oportuno de apresentar ainda algumas recepçóes teóricas do isebiano em questão.

\section{A PLURALIDADE DO NACIONAL-DESENVOLVIMENTISMO}

A historiadora Sonia Regina de Mendonça em sua obra Estado e Economia no Brasil: Opçóes de Desenvolvimento irá dissertar, ao abordar o governo JK, sobre o papel do ISEB na conjuntura econômica e política do país. A autora observa que o debate nacionalista sobre a intervenção estatal, muito forte nos primeiros anos da década de 1950 durante a era Vargas, ganha novos contornos incluindo a questão da participação do capital privado em função da própria integração capitalista do Brasil neste período. Um consenso dos estudiosos que se aprofundam sobre o período é que o nacionalismo não era único, existiam algumas vertentes que eram identificadas enquanto tais. Mendonça estabelece três distinçóes: 1) O nacionalismo neoliberal, que considerava o capital estrangeiro bem vindo para o desenvolvimento e sem a necessidade do controle do Estado, encampado pela União Democrática Nacional (UDN); 2) O nacionalismo radical, que rejeitava a participação do capital estrangeiro na industrialização do país acusando um aprofundamento da subordinação aos Estados Unidos, compartilhado pelo 
PCB e setores do PTB; 3) O nacionalismo-desenvolvimentista, que propunha a entrada de capital estrangeiro com a participação do Estado, o governo de Juscelino Kubitschek, o ISEB e a burguesia industrial compunham essa vertente (MENDONÇA, 1999, p. 60).

Ao dividir os nacionalismos com o objetivo de diferenciá-los, a autora acaba colocando correntes distintas sobre o tema dentro da mesma categoria de "nacionalismo-desenvolvimentista", assim como a inclusão da UDN e dos adeptos do liberalismo como um tipo de nacionalismo torna-se controverso ${ }^{1}$. Sob esta última questão, a historiadora parte de uma premissa correta de que na época ninguém se intitulava "antinacionalista”. Porém, é necessário irmos além das auto intitulaçôes de setores em disputa na época e analisarmos a capacidade desses grupos serem, minimamente, legitimados eaceitos em sua própria contemporaneidade. Jaguaribe irá comentar em sua obra Nacionalismo na atualidade brasileira que nos debates políticos da época o campo progressista criou a pecha de "entreguista" para os setores mais liberais. De fato, mais além das adjetivaçôes dos setores progressistas, a ala conservadora com ideias liberais na economia não havia produzido qualquer identificação bem sucedida enquanto nacionalistas para a sociedade, pelo contrário, o nacionalismo foi muito associado pela UDN ao totalitarismo. Se antes da II Guerra Mundial, Getúlio Vargas foi diversas vezes acusado de práticas fascistas, após o fim da guerra o comunismo foi fortemente vinculado às pretensões totalitárias, e muitas vez tal vínculo foi estendido para outros setores progressistas. Carlos Lacerda, célebre udenista, irá afirmar em 1962 que refutava o nacionalismo por colocar a nação acima do indivíduo, ele acreditava que seu partido não era nacionalista e foi taxativo sobre o tema: "O nacionalismo moderno é um fator de guerra e de conflitos. Serviram-se do nacionalismo, o nazifascismo ontem; e o hoje, o comunismo." (LACERDA, 1965, p. 91).

César Guimarães circunscreve o nacionalismo no Governo Vargas enquanto "uma economia planejada 'além da conta' e de uma política externa independente” (GUIMARÃES, 2001, p.151) e vai compreender que no pós-guerra houve uma ressignificação do termo relacionando-o à descolonização e ao fortalecimento de "economias frágeis" do terceiro mundo. Sendo, em termos genéricos, o nacionalismo na década de 50 compreendido através um "protecionismo e estatismo". Se considerarmos também os critérios de Pedro Fonseca (2015) existiriam três características fundamentais do pensamento desenvolvimentista. A primeira seria a existência de um projeto nacional, descrito por ele como "um projeto deliberado ou estratégia tendo como objeto a nação e seu futuro" (FONSECA, 2015, p. 7). As outras duas a ela somadas seriam a intervenção estatal consciente e deliberada - planejamento 
- e a compreensão de que a industrialização seria o caminho mais adequado para superar o atraso econômico, político e social tal como percebido pelos teóricos e atores políticos. Para o autor são igualmente pressupostos fundamentais a intencionalidade na defesa destes três pontos e que ela seja feita dentro dos marcos de uma economia capitalista.

Ao partirmos dessa definição de Guimarães e de Pedro Fonseca sob a luz da conjuntura histórica da época, identificamos dois problemas nas divisões sobre o nacionalismo realizado por Mendonça. O primeiro consiste numa inclusão equivocada da UDN enquanto nacionalista ao categorizar uma vertente de "nacionalismo neoliberal". O segundo problema trata-se da dilatada composição do intitulado "nacionalismo-desenvolvimentista", colocando diversos setores pensantes da sociedade sob o mesmo signo, e, além disso, todos responsáveis e atrelados às realizaçôes do Governo JK. Em sentido contrário, temos que fazer o exercício de tratar o desenvolvimentismo e o nacionalismo enquanto categorias diferentes e entender que o termo "nacional-desenvolvimentismo" foi utilizado enquanto bandeira política de diversas formas e por diferentes grupos que alcançaram ou não o Estado. Exemplo disto se dá na diferença entre o que defendiam teóricos reunidos em torno do ISEB e da ESG. Embora ambos se encaixam no conceito de desenvolvimentismo de Pedro Fonseca, o projeto político-econômico dos dois think tanks tinham diferenças fundamentais. Nas produçóes de Hélio Jaguaribe, veremos que a sua caracterização de desenvolvimento será utilizada para "qualificar" o nacionalismo por ele defendido diferenciando-o dos demais.

$\mathrm{Na}$ referida obra de Mendonça existe um grande esforço para atrelar as formulações isebianas aos planos de desenvolvimento do Governo de Juscelino. O argumento "forte" da autora consiste em apontar a semelhança de um determinado discurso público de $\mathrm{JK}$ com as definiçóes gerais dos objetivos do ISEB (MENDONÇA, 1999, p. 64). A autora chega a fazer a ressalva de que não havia um consenso sobre o modelo de desenvolvimento ideal dentro do ISEB, principalmente sobre a utilização do capital estrangeiro, porém, em contrapartida afirma que a linha do nacionalismo "moderado" de Hélio Jaguaribe prevaleceu no Instituto. Tal afirmação é inconsistente já que a publicação da obra de Jaguaribe $O$ nacionalismo na atualidade brasileira, na qual expõe sua versão do nacionalismo brasileiro, tornou-se polêmica dentro e fora do ISEB, tornando-se o pivô de sua saída. Porém, a despeito desta questão, há um ponto central em que divergimos da autora: as formulaçôes de desenvolvimento do ISEB e especificamente do Hélio Jaguaribe não foram assumidas pelo governo de Juscelino Kubitschek. Realizar tal referência trata-se de uma leitura superficial sobre o Instituto. 
Ressaltaremos alguns aspectos que demonstram que a ideias de Hélio Jaguaribe não se concretizaram em políticas públicas no período juscelinista. Primeiro, o conceito de desenvolvimento nacional formulado por Jaguaribe previa um planejamento amplo que ia para além da economia. $\mathrm{O}$ isebiano via com bons olhos os esforços de medidas econômicas que foram empreendidos por Dutra e Vargas em seu último governo, levando a uma série de estudos e levantamentos de dados úteis, assim como o Plano de Desenvolvimento do então presidente Juscelino Kubitschek para o quinquênio. Porém, o autor apontava a necessidade de tal plano quinquenal se transformar de fato em planejamento econômico com um grau de "integração e sistematicidade". Para além do planejamento econômico prioritário, Hélio Jaguaribe defendia a extensão para outras áreas, como a educação, saúde, a relação entre classes sociais e o estatuto do trabalho, assistência social e funcionamento dos aparelhos estatais. Sendo assim, o autor adotou uma visão mais ampla, na qual outros setores da nação deveriam estar inclusos neste projeto de desenvolvimento. Esta perspectiva de tratar o desenvolvimento nacional desde uma visão que integra diversas áreas da sociedade retoma uma perspectiva "mannheimiana”, que privilegia a posição do intelectual que esteja num lugar epistemológico acima de setores e áreas sociais específicas sendo capaz de mobilizar interesses gerais da sociedade.

[...] o planejamento brasileiro, transcende, duplamente, a área do meramente econômico, quer pelo fato de o desenvolvimento ser uma categoria que se refere a uma estrutura-tipo de uma comunidade, desta forma abrangendo todos os aspectos da vida social [...]. (JAGUARIBE, 1979, p. 212).

No ensaio "A crise Brasileira" do próprio autor, publicado no Cadernos de Nosso Tempo, em 1953, Jaguaribe já indicava a amplitude do que estava em crise: "A crise brasileira [...] se desenvolve em todas as profundidades e em todos os setores da vida nacional" (JAGUARIBE, 1981, p. 132). Portanto, a solução da crise brasileira de tamanha extensão necessitava um planejamento amplo. De tal forma que o escritor isebiano irá incluir temas de envergadura nacional em sua análise acerca do desenvolvimento, como as classes sociais e suas respectivas ideologias.

O Programa de Metas, conhecido enquanto Plano de Metas foi um programa de desenvolvimento econômico do governo Juscelino Kubitschek. Ele teve como base os diagnósticos realizados pelo Grupo CEPAL-BNDE que estudou as demandas da economia brasileira e contou também com grande influência da Comissão Mista Brasil-Estados Unidos.

O Plano tinha como objetivo maior elevar o padrão de vida dos brasileiros e constituía-se de projetos de desenvolvimento que se dividiam em cinco grandes 
setores: energia, transportes, indústria de base, alimentação e educação. Cada um dos setores estava dividido em metas, que totalizavam 30. Era ainda parte do Plano a construção de Brasília, cujos projetos de transporte estavam especialmente articulados. (CAPUTO \& COSTA, 2009, p. 375).

A pretensa extensão do Plano tinha, na realidade, como enfoque a área essencialmente econômica. Os efeitos do programa em outras áreas se deram principalmente através das alterações do padrão econômico do país e não através de políticas públicas específicas. A principal exceção foi a criação da Superintendência do Desenvolvimento do Nordeste (SUDENE) idealizada por Celso Furtado, já no final do Governo JK em 1959.

Dentro da área econômica, Jaguaribe teve uma crescente preocupação com o papel do Estado no controle do planejamento econômico e para evitar os chamados "grupos de pressão", ou seja, a interferência indevida da iniciativa privada nos assuntos públicos. O modelo de desenvolvimento econômico defendido por Hélio Jaguaribe tinha como condição fundamental a constituição de uma indústria de base, capaz de produzir bens de produção que na situação cambial em que se encontrava o país era impossível de se obter através de importaçóes. Tal fato geraria um equilíbrio na balança comercial brasileira. $\mathrm{O}$ intelectual propunha a necessidade de uma economia capaz de "organizar e disciplinar o sistema produtivo do país" (JAGUARIBE, 1981, p. 200).

Hélio Jaguaribe constatou que a ausência de capitais nacionais aliados às novas condições de investimentos estrangeiros fazendo com que os investimentos não tendessem a serem realizados segundo critérios de maior essencialidade, além do mais, devido à crise estrutural não se permitia um rompimento do país com a então atual crise econômica. Esse diagnóstico, que em síntese apontava que o capital de forma espontânea não teria capacidade de superar a crise, seria fundamental para um ponto central da proposta de desenvolvimento econômico de Hélio Jaguaribe: a intervenção estatal.

[...] a modificação das condições produtivas exige uma intervenção planificadora do Estado que, direta ou indiretamente, organize a economia do país para os fins em vista, estimule ou desestimule determinadas atividades, coordene os fatores, discipline os investimentos e assuma, promocional ou supletivamente, certos encargos produtivos. A intervenção planificadora, promocional e supletiva do Estado constitui, assim, a primeira das condiçóes necessárias para que o impasse crescimento econômico-desequilíbrios estruturais seja vencido sem prejuízo do desenvolvimento econômico. (JAGUARIBE, 1981. p. 201).

Jaguaribe considerava fundamental manter um “ajustamento" entre o plano econômico e o mercado. Para tal, era importante manter uma autonomia do planejamento dentro da economia como um todo. O isebiano alertava 
para uma tendência do livre mercado alterar os setores planejados da economia ao passo que isso levaria a uma solução de efetuar um planejamento total da economia. Ambos os casos, segundo o autor, poderiam ser evitados no Brasil. O autor defendia que a modalidade deste planejamento poderia ser baseada através do induzimento, de maneira que os agentes públicos e privados respeitassem os termos do plano. Ao se perguntar quais sãos as áreas da economia no Brasil que deveriam ser inseridas no planejamento econômico, o autor cita a fase em que o país se encontrava e sua estrutura-tipo, na qual a prioridade era "assegurar as ótimas condiçóes para o desenvolvimento econômico-social”. Hélio Jaguaribe, ao traçar o objetivo maior em que "o país deve assumir um destino próprio e afirmar-se como comunidade independente e autônoma”, aponta que a metas necessárias a curto e médio prazo teriam um caráter de "univocidade" independe do viés ideológico (JAGUARIBE, 1981, p. 211-212). Assim sendo, o intelectual acreditava ser impreterível uma reforma do Estado, que deixasse de ser obsoleto para o desenvolvimento tornando-se funcional e não mais ser vulnerável aos "grupos de pressão" de interesses privados, o Estado obsoleto e vulnerável era qualificado pelo autor enquanto um "Estado cartorialista". Por outro lado, o governo JK foi marcado de fato pela participação efetiva do Estado na industrialização do país através de um plano de desenvolvimento que associava a indústria nacional ao capital estrangeiro. Como aponta Sônia Draibe em sua obra Rumose Metamorfoses: Estado e industrialização no Brasil (1930-1960):

[...] o Estado definiu um conjunto integrado de investimentos e assegurou as condições mínimas de financiamento, estendendo ao limite o seu poder de regulação e capacidade fiscal e financeira. A profundidade alcançada pela internacionalização da economia foi definida nos marcos da relação - aparentemente paradoxal - entre o empresariado nacional e o Estado. (DRAIBE, 2004, p. 225).

Desta forma, apontamos que dentro do que Sonia Regina de Mendonça qualifica enquanto "nacionalismo-desenvolvimentista” há muitas diferenças que tornam de difícil aceitação esta categoria proposta para designar um determinado tipo de nacionalismo. A partir do pressuposto de que Hélio Jaguaribe e o ISEB foram ideólogos do desenvolvimentismo que se realizou, a autora irá tratar a malograda tentativa de industrialização autônoma e a sua formulação intelectual nos termos de "mascaramento" da industrialização associada ao capital estrangeiro. Portanto, para a autora, o ISEB, assim como outros setores do nacional-desenvolvimentismo, era instrumento da burguesia industrial que "obscurecia [...] o papel político desempenhado pelos empresários industriais, dando margem a uma visão distorcida sobre suas articulações políticas com as empresas estatais e as multinacionais" (MENDONÇA, 1999, p. 61). O caminho que adotamos aqui foi o de situar as 
ideias de Hélio Jaguaribe em seu contexto para destacar como ele se valeu da linguagem do desenvolvimentismo para propor soluçôes específicas para o desenvolvimentos nacional.

\section{O NACIONALISMO EM HÉLIO JAGUARIBE}

Para melhor entender no que consistia o nacionalismo de Hélio Jaguaribe e sua relação com o conceito de desenvolvimento, é preciso colocá-lo em quadro mais amplo, tanto internacional quanto doméstico. Dentro do primeiro cenário, é fundamental destacar a mudança na condução das políticas econômicas mundiais no período pós II guerra mundial. A perspectiva de um Estado ator, que coordenasse as atividades produtivas e promovesse o bem-estar social ganharam força. Tal como destaca Fiori (1999), os EUA saíram pouco afetados do conflito bélico e, impulsionados pela nova competição geopolítica, agora com a União Soviética, o país se tornou credor da Europa através do plano de reestruturação das economias afetadas - conhecido como Plano Marshall. No ambiente doméstico norte-americano, o Estado foi impulsionador fundamental das atividades tecnológicas, com o fim de fazer frente à potência socialista. Enquanto isso, nos países da Europa Ocidental, o entendimento da ampliação do papel do Estado em questôes econômicas e sociais é compartilhado através do conceito de planejamento. Em dados trazidos pelo historiador britânico Tony Judt (2007), em maior de 1946 um quinto da capacidade industrial francesa pertencia ao Estado.

No caso de países do sul-global, César Guimarães (2001) afirma que estas "ideias-força” foram recepcionadas a partir do conceito de desenvolvimento. Por sua vez, este era visto pelos movimentos decoloniais na África e na Ásia como forma de reparar assimetrias internacionais, permitindo através da afirmação de uma cultura e de uma administração política centrada em seus interesses locais, a expansão das benesses da socialdemocracia para regióes vistas como periferia do mundo. Segundo frase do mesmo autor: "[...] descolonização, nacionalismo econômico, planejamento são nomes da esperança” (GUIMARÃES, 2001, p. 158).

Dentro deste contexto maior, o Brasil compartilhava desta busca pelo desenvolvimento como forma de superar seu "atraso" frente ao Ocidente. $\mathrm{Na}$ História nacional, este movimento já era sentido como em curso desde a revolução de 1930 . Para Wanderley Guilherme dos Santos o evento que encerrou a Primeira República teria sido um "divisor de águas" (SANTOS, 1970 , p. 20) no pensamento político brasileiro. A partir dele, teriam começado a ganhar força pautas de uma tradição que o autor chama de nacionalista. Dentre suas características estariam uma visão dicotômica entre um 
Brasil agrário e um Brasil industrial, a busca de singularidades do país e a crítica a tentativas de transplantação mecânica de ideias estrangeiras. Ainda no Estado Novo, autores como Oliveira Viana e Azevedo Amaral se destacaram como defensores de um modelo de entrada do Brasil na modernidade encabeçado pelo Estado. Nos anos posteriores, o otimismo gerado pelos resultados econômicos do Estado atuante fez com que os mais diversos atores defendessem modelo similar. No entanto, não havia entre eles consenso sobre o significado de nacionalismo e de desenvolvimento

Dentre os centros que se propunham intervir no debate público através da defesa de um ideário desenvolvimentista estava o Instituto Superior de Estudos Brasileiros (ISEB), o qual Hélio Jaguaribe era membro fundador . Segundo Angélica Lovatto (2006) a trajetória do think tank pode ser dividida em três fases: na primeira, iniciada em 14 de julho de 1955, não haveria consenso ideológico; já na segunda, o nacional desenvolvimentismo seria hegemônico e os isebianos estariam preocupados em pensar um projeto a ser encampado pela burguesia nacional; na terceira e última, de 1961 até 1964, a instituição estaria comprometida com a defesa das reformas de base de João Goulart.

Embora fosse um centro especializado na formação de uma ideologia nacional-desenvolvimentista, o ISEB era heterogêneo em sua composição Dentre as diferentes perspectivas estava a do sociólogo e teórico trabalhista Alberto Guerreiro Ramos. Ele compreendia que o trabalhador era espécie de sócio do desenvolvimento nacional e uma força política sem a qual nenhum governo se sustentaria. O intelectual previa uma relação direta entre planejamento econômico do Estado e interesse popular, que vincularia a questão nacional aos interesses dos trabalhadores. Seria necessária ainda uma aliança política entre os setores interessados em soluçôes nacionais para o desenvolvimento do Brasil para que o processo se realizasse. Outra posição relevante dentro do ISEB era a de Nelson Werneck Sodré. Enquanto membro atuante no Partido Comunista Brasileiro (PCB), o historiador via o processo de desenvolvimento de forma similar a de Guerreiro Ramos, no entanto, para ele, a questão se tratava de uma etapa. Percebendo a questão como análoga a uma revolução burguesa, ela seria a condição necessária para atingir-se o comunismo no futuro.

Fora do âmbito do instituto, a Escola Superior de Guerra (ESG) também era locus privilegiado de discussão sobre o nacional-desenvolvimentismo, embora com entendimento deveras diverso da questão. Segundo um dos principais intelectuais da instituição, Golbery de Couto e Silva, o nacionalismo e a necessidade de levar a frente um processo de desenvolvimento estaria conectado a necessidade de manutenção da soberania e da segurança 
nacional. Em sua obra Geopolitica do Brasil (1981) ele critica as outras visões como distorcidas e afirma haver ameaça de invasão do país por ideias comunistas. O remédio seria o fortalecimento do ideal nacional e a garantia de qualidade de vida e subsistência para que setores populares não aderissem a ideais marxistas.

Ponto de discordância fundamental deste autor com Hélio Jaguaribe é no entendimento do lugar do nacionalismo no pensamento desenvolvimentista. $\mathrm{O}$ isebiano defendia um nacionalismo pragmático, como meio para atingir um fim: "O nacionalismo, como se viu, não é imposição de nossas peculiaridades, nem simples expressão de características nacionais. É, ao contrário, um meio para atingir um fim: o desenvolvimento" (JAGUARIBE, 1958, p. 52). Golbery inverte a relação de causalidade, colocando o desenvolvimento a serviço do nacionalismo. Com isso, ele diverge ao mesmo tempo da concepção de Jaguaribe e do ISEB em geral:

O nacionalismo é, portanto, deve ser, só pode ser um absoluto em si mesmo um fim último - pelo menos enquanto perdurar a nação como tal. Lugar não há, nem deve haver, nem poderá haver para o nacionalismo como simples instrumento de um fim que o transcenda, como degrau, apenas numa escala que o transmonte. Isso nunca será nacionalismo - será engano, será burla, será até mesmo chantagem. (SILVA, 1981, p. 99)

A principal obra de intenção de Hélio Jaguaribe no debate foi $O$ nacionalismo na atualidade brasileira, de 1958, escrita na fase nacional-desenvolvimentista do ISEB. Portanto, assim como a obra Para uma politica de desenvolvimento nacional, dificilmente conseguiremos depreender as principais características do pensamento político de Jaguaribe e sua intervenção no acirrado debate desenvolvimentista se passarmos ao largo deste livro. Ametodologia que perpassa o livro tem inspiração em procedimento hegeliano. $\mathrm{O}$ autor entende a história a partir do movimento das ideias vistas por categorias dicotômicas que representariam teses e antíteses. Deste modo, Jaguaribe pretendia propor espécie de síntese dialética do debate sobre o nacional-desenvolvimentismo.

Com o intuito de se posicionar na disputa intelectual sobre o significado desta ideologia, logo no prefácio de seu livro o cientista político aponta que o grande fator que motivou este trabalho foi um panorama por ele diagnosticado de uma grande incompreensão sobre o nacionalismo no Brasil. Tal fato gerava barreiras para a adoção de políticas "racionais" além de radicalismo e "aventureirismo anti-social e antinacional” (JAGUARIBE, 1958, prefácio). O combate às más interpretaçôes sobre o nacionalismo viria através de um trabalho de precisar esta categoria lhe conferindo objetivos claros. Dá-se aí a relevância desta obra, “[...] evitando-lhes que as controvérsias semânticas 
ou as idiossincracias pessoais separem homens e forças que de fato têm os mesmos propósitos e se acham ligados às mesmas solidariedades." (JAGUARIBE, 1958, prefácio). O caráter aglutinador e até mesmo harmônico do nacionalismo será uma das características desenvolvidas pelo o autor. $\mathrm{Na}$ apresentação da obra, conferindo ainda mais importância ao tema, ele afirma que esta categoria traçaria uma "linha divisória" nos mais importantes debates políticos do país, dividindo-os em dois grupos: "nacionalistas" e "entreguistas". Os de segunda categoria, apesar de não se auto denominarem assim, agiriam tentando esvaziar as significações do nacionalismo, caracterizando-o em aspectos negativos, enquanto os primeiros se caracterizariam muito mais em sua oposição do que propriamente dito por características genuínas.

A divergência entre nacionalistas e entreguistas (ou cosmopolitas) teria a ver com a manutenção do antigo regime produtivo do Brasil. Associando os cosmopolitas aos latifundiários, seus quadros políticos e seus intelectuais que, como Eugênio Gudin, defendiam a manutenção das bases agrárias da matriz econômica nacional, Jaguaribe afirmaria que esta corrente defenderia as mesmas políticas econômicas liberais presentes desde o Império até a República. Como antítese desta posição, os nacionalistas prefeririam um dirigismo que favorecesse a industrialização, com políticas protecionistas e de transferência de renda, buscando a soberania nacional. Embora não disfarce sua preferência pelo nacionalismo, oautor queria, acima de tudo, superar as duas correntes. Quando estudou a história da gestão econômica do Brasil, ele reconheceu excesso dos dois lados. A busca de Hélio Jaguaribe pela síntese das ideologias autóctones, o fez concluir que o problema estaria no fato de que ocosmopolitismo subestimaria a capacidade nacional de investimentos e o nacionalismo pecaria pelo oposto. A síntese estaria no equilíbrio.

Desta forma, um esforço de esclarecimento se fazia necessário e urgente no país. Nesta altura, o isebiano condiciona o sucesso do nacionalismo a sua prévia formulação. Oargumento que sustenta tal condicionamento é a explicação de que se trata de um fenômeno que não ocorre "a despeito da consciência dos protagonistas” (JAGUARIBE, 1958, p. 13). Portanto, no sentido de "encruzilhada", o nacionalismo também era uma possibilidade para o Brasil, mas não um destino inevitável. "Daí o dilema [...] ou alcança uma formulação mais consistente [...] e determina o curso subsequente de nossa história, ou malogra [...] a condição mesma de o povo brasileiro realizar uma história nacional”. (JAGUARIBE, 1958, p. 14).

Jaguaribe irá aprofundar a noção de que o nacionalismo antes de uma ideia racional se trata de um fenômeno histórico político, portanto, tal categoria só se pratica se houver condições necessárias na comunidade. Ao 
conferir ao nacionalismo enquanto um produto de fenômenos históricos e sociais, o isebiano retira do indivíduo e de seu voluntarismo acapacidade de exercer naturalmente tal categoria, desta forma, o nacionalismo sai do centro de associaçôes de juízos de valores humanos, como "bem ou o "mal”, e passa a ser tratado em sua dimensão estrutural.

Enquanto fenômeno histórico-social, o nacionalismo surgiria do choque de condiçốes objetivas com condições subjetivas. As primeiras seriam de ordem histórica (estabelecimento de uma Cultura ocidental a partir do Renascimento), sociais (como forma de organização de uma comunidade) e geográficas (fixação territorial). Já as condiçôes subjetivas seriam de ordem cultural: cosmovisão, linguagem, arte, instituiçôes e tecnologia. A Nação se constituiria como tal quando, dadas algumas condiçốes objetivas, o fator subjetivo agregaria a formulação de um projeto de integração nacional. Sem ele uma nação no sentido histórico não se tornaria uma nação no sentido político. O nacionalismo seria aspiração fundadora epreservadora da nacionalidade que, dada as condiçóes objetivas para tal, se constitui como projeto nacional. No sentido que Ortega y Gasset (s.d.) dá ao termo, a Nação e o nacionalismo surgiriam no pensamento de Hélio Jaguaribe como crenças coletivas.

Portanto, Jaguaribe vai apontar que a constituição de uma nação se dará através de um projeto político, que a funde e a mantenha. Para além da solidariedade objetiva de seus membros, a nação necessitaria de um projeto nacionalista - para preservá-la e desenvolvê-la. O isebiano irá nomear essa relação entre as condiçóes objetivas de laços dos povos e o seu projeto político enquanto "dialética da nação". Desta forma, o nacionalismo será preservador da nacionalidade:

A nação, em sentido histórico, precede a nação, em sentido político. Mas nem todas as naçốes, em sentido político. Mas nem todas as nações, em sentido histórico, ou seja, nem todas as comunidades dotadas de unidade de raça e de cultura, habitando o mesmo território "natural", chegam a constituir uma nação. (JAGUARIBE, 1958, p. 21).

$\mathrm{O}$ isebiano distingue o nacionalismo integrador do nacionalismo imperialista. O primeiro teria como propósito promover e preservar uma nacionalidade "historicamente possível", pertenceram a essa categoria os países europeus e os EUA no século XVIII, já no século XX, os países da Ásia, África e América - Latina se encontrariam nesta situação. $\mathrm{O}$ segundo representa um desenvolvimento que já extravasou e superou o seu enquadramento nacional, já plenamente conformada, com um nacionalismo recrudescido, com potencial agressivo para com outros países. Os países europeus e os EUA são membros desta categoria. Jaguaribe disserta sobre a existência de um certo 
tipo de "incompreensão" sobre o nacionalismo integrador por parte das nações imperialistas, pois estas já se afastaram historicamente dessa experiência de integração, e muitas vezes julgam que o nacionalismo integrador é uma ameaça global.

A noção histórica do nacionalismo em Jaguaribe está intrinsecamente ligada ao de desenvolvimento, na qual seria um projeto político integrador da comunidade. Desta forma tal projeto se realiza quando compreendida enquanto uma necessidade.

Às nações européias, em sentido histórico, preexistiram a esse processo integrativo. O simples fato de diversas comunidades falarem a mesma língua, dentro da mesma cultura [...] não conduziu, todavia tais comunidades a integrarem o mesmo ordenamento político jurídico, enquanto tal existência não lhes foi imposta enquanto necessidades vitais. (JAGUARIBE, 1958, p. 28)

Assim sendo, o autor aponta que o projeto nacionalista é deliberado no sentido de exprimir uma decisão política sobre a nação, porém, indeliberado ao ser consequência de necessidades humanas. Desta última premissa o autor relaciona ao humanismo, onde o nacionalismo seria meio para organizaçóes sociais mais elevadas da humanidade, "tem como sentido finalístico a realização de um modelo de humanidade”. (JAGUARIBE, 1958, p. 29).

Ao analisar o desenvolvimento das condiçôes sócio-históricas do Brasil para o nacionalismo se estabelecer enquanto uma possibilidade, os elementos apresentados são os mesmos que dois anos antes o autor utilizou para justificar a viabilidade histórica do desenvolvimento no país, em sua obra Para uma politica de desenvolvimento nacional. Ao longo desta obra de 1958, as categorias de nacionalismo e desenvolvimento nacional vão se aproximando. O autor afirma que desde a década de 1920, movimentos nacionalistas foram aparecendo de forma esparsa e fragmentada, fruto de sua viabilidade sóciohistórica. No campo da cultura o autor cita o movimento modernista de 1922. No campo econômico, o autor identifica também a eclosão de um nacionalismo que reivindica os monopólios estatais da exploração do petróleo e dos minerais. Já na área da política outro nacionalismo surgiu sob a bandeira da justiça social e democracia, além de um fortalecimento da União e uma maior autonomia nas relações internacionais perante os EUA.

O panorama econômico do Brasil permitiu surgir um tipo de nacionalismo em oposição ao cosmopolitismo. Se a economia agroexportadora, trazendo os bens de consumo e as ideias de fora, formara um pensamento cosmopolita, a transformação econômica com a constituição de um mercado interno permitiu o desenvolvimento de do pensamento nacionalista. Em relação à composição social, o cosmopolitismo estava presente na burguesia latifúndio-mercantil e nos setores parasitários da classe média. Já o 
nacionalismo, nos setores mais modernos das classes sociais, ou seja, nos industriais, proletariado, e setores técnicos e intelectuais da classe média. Porém, essa manifestação ideológica do nacionalismo em oposição ao cosmopolitismo é caracterizada por Hélio Jaguaribe enquanto incondicional.

O nacionalismo superestimando a capacidade nacional de investimento e especialmente o preparo tecnológico do país considera com ceticismo ou com receio o investimento estrangeiro e se inclina para uma política de capitalismo de Estado, atribuindo aos poderes públicos, particularmente na órbita da União, o principal encargo de promover o desenvolvimento econômico do país. (JAGUARIBE, 1958, p. 34).

Portanto, se por um lado haveria uma postura que subestimava o Brasil e a capacidade nacional de desenvolvimento, recorrendo essencialmente ao capital estrangeiro, por outro lado, o nacionalismo era incondicionalmente contra o regime de capital estrangeiro no país. Desta forma, mais do que representar uma ideologia autêntica, ambas acabam pendente para a ideologia de suas classes.

A pura e simples afirmação de confiança nas potencialidades do país e o sentimento de auto-suficiência, não controlados criticamente pela consciência das limitaçóes nacionais e pro critérios comparativos, conduz naturalmente as mentalidades mais rudimentares e incultas a um nacionalismo incondicional, tendencialmente xenófobo e propenso a erigir a própria condição em ideologia. (JAGUARIBE, 1958, p. 35).

Vejamos que ao citar, no trecho acima, à "própria condição de classe", tratava-se de uma versão "primária” do nacionalismo, ausente da ideologia do desenvolvimento e composto da imaturidade das consciências dos setores sociais que a propagavam. Portanto, "incondicional", "inculta” e "rudimentar", são os opostos da "racionalidade" presente em um nacionalismo que contivesse a ideologia do desenvolvimento. Desta forma, as oposiçóes entre nacionalismo e cosmopolitismo preenchiam o panorama de um antagonismo pouco propositivo para o desenvolvimento.

O nacionalismo sem um planejamento nacional gerava contradiçóes. Partindo dessa premissa, Jaguaribe irá levantar algumas delas. Dissertaremos aqui sobre três: a econômica, a social e a política. No campo econômico, a contradição se baseava na tentativa de um desenvolvimento sem a utilização de capitais estrangeiros, porém, diante de uma realidade econômica carente de capitais "poupáveis ao consumo e aplicáveis em investimentos”(JAGUARIBE, 1958, p. 37). Tal carência agravaria o subdesenvolvimento no Brasil.

É exatamente contra o capital estrangeiro, todavia, que, de modo geral, se insurge o nacionalismo, nele vendo um fator de espoliação das riquezas naturais do 
país e um processo de agravamento de nossa dependência colonial. (JAGUARIBE, 1958, p. 38)

Ocorre uma mudança da postura de Hélio Jaguaribe sobre o papel do capital estrangeiro no desenvolvimento econômico do Brasil. Dois anos antes, na obra Para uma politica de desenvolvimento nacional, o autor analisava que a entrada de capitais estrangeiros não era um fator importante para o desenvolvimento do país. Segundo Jaguaribe, o capital estrangeiro já não seria mais "a salvação do país”, não representava um fator de desenvolvimento para o país, pois, tornou-se um ônus para a balança de pagamento. Para sustentar tal argumento, o autor apresenta o estudo do Banco do Brasil de 1953 que mostra que as entradas e saídas de capitais estrangeiros no Brasil durante o período de 1941-1952 apresentou um déficit de mais de Cr\$16,5 bilhões. Porém, uma opção de utilização do capital estrangeiro seria a possibilidade de empréstimos a prazo médio através de vendas financiadas de equipamentos. Segundo o autor, tal modelo se mostrara bem sucedido na Europa.

Sem explicitar sua mudança de opinião, o autor afirma que tal contradição poderia ser contornada se o Estado houvesse tomado medidas que incrementassem a capacidade nacional de investimento. Porém, na situação econômica que o país se encontrava, aumentar a capacidade nacional de investimento passaria por reduzir o consumo e elevar a produtividade, duas medidas que se tornaram inviáveis. A crítica também aponta na direção de um protecionismo nacionalista gerar uma baixa produtividade da indústria nacional devido à ausência de concorrência internacional, diminuindo a capacidade de renda nacional.

As contradiçốes da área social e política estão bem intrínsecas, sendo a política apresentada como uma síntese das contradiçóes econômicas e sociais. No campo social, refere-se à "[...] desproporção entre os benefícios auferidos ou desejados e a participação de cada qual na criação ou preservação de bens e valores sociais" (JAGUARIBE, 1958b, p. 40). Ou seja, a classe trabalhadora e a classe média não participam como potencialmente poderiam da produção nacional, porém, a consomem desproporcionalmente. Em relação à classe trabalhadora, Jaguaribe aponta que como não desenvolveram a consciência para lutar por uma sociedade que consolidasse a igualdade nas oportunidades de ascensão social (meritocracia) e a falta de igualdades sociais, a via "consistente e responsável" segundo o autor, acabaram investindo contra a espoliação de forma "inorgânica", através do populismo: "Deixando-se galvanizar por demagogos carismáticos [...]” (JAGUARIBE, 1958b, p. 41). Oresultado seria o aumento de "processos suicidas de consumo", gerando inflação e caos social. Por parte da classe média, o tema do "Estado cartorial” volta à tona: 
como o Estado teria se tornado um local da política de clientela e não uma esfera de prestação de serviços, a classe média, historicamente marginalizada do processo de produção, se ocupou de tais cargos de forma parasitária em sem desempenhar funçóes públicas em prol da sociedade. Desta forma, "a função do estado se limitou à arrecadação fiscal, para atender a uma despesa quase toda aplicada na remuneração do próprio funcionalismo" (JAGUARIBE, 1958b, p. 41).

A contradição, no campo político se encontrava, portanto, em almejar o desenvolvimento com o capital nacional e participação estatal sendo o próprio Estado uma estrutura cartorial, por conseguinte, obsoleta para o desenvolvimento e ao mesmo tempo que geradora de um déficit público. Portanto, aí reside o pecado do populismo e do clientelismo: o estrangulamento da condição econômicas do país, além de "acomodarem” ideologicamente o proletariado e a classe média, distanciando-os de uma ideologia do desenvolvimento.

A partir de uma visão hegeliana, Hélio Jaguaribe ressaltava em termos dialéticos que as contradições da atual fase brasileira e até as contradições dos modelos de organizaçóes sociais pelo mundo permitiriam as possibilidades de mudança de fases sócio-históricas das comunidades: “[...] todo processo histórico consiste na transformação de estruturas, em virtude e por meio de modificaçóes que conduzem a impasse as estruturas anteriores e forçam a criação de formas novas de organização e de trabalho.” (JAGUARIBE, 1958b, p.47). Após as condições dialéticas existirem, o autor depositaria em uma ação do campo da consciência, no sentido idealista, a capacidade de superar tais contradições. Logo, "a superação de tais incongruências depende, assim, de uma atuação cultural ou política que reajuste o movimento nacionalista aos imperativos do desenvolvimento, fim imediato que o suscita e orienta”. (JAGUARIBE, 1958b, p.58).

Essa dialética idealista irá orientar sua percepção histórica do desenvolvimento do Brasil e as condiçôes para interferir em seu curso. Neste sentido, mais do que reunir e saber direcionar elementos materiais, a priori o isebiano buscou compreender o "espírito" do movimento nacionalista. Isso o faz ter uma preocupação em compreender a ideia por trás de sua "força”. Não fugindo desta regra, portanto, o nacionalismo, a despeito de suas "versóes" primárias e esparsas, se constituiria para Jaguribe através de uma ideia que lhe orienta e lhe identifica como a versão correta e certeira dentre os nacionalismos contraditórios e impotentes. Portanto, o que daria sentido ao nacionalismo seria a sua ideologia.

Nesta direção, o nacionalismo é definido pelo cientista político enquanto um movimento provocado pelo desenvolvimento do país que ao mesmo 
tempo tem a finalidade de "acelerá-lo" e "racionalizá-lo", torna-se importante para o autor que tal movimento seja um "fim" e não um "meio". Em outras palavras, se a finalidade do nacionalismo é estabelecer

o desenvolvimento, não serão os meios empregados que definirão se é o ou não de fato nacionalista.

Compreende-se o nacionalismo como uma ideologia destinada a cumprir uma missão na fase histórica em que se encontrava o Brasil. $\mathrm{Na}$ medida em que o desenvolvimento econômico-social tivesse lugar, ele tenderia a desaparecer, A afirmação da Nação serviria como antítese da imposição da condição periférica e subdesenvolvida para o Brasil. Longe de uma noção essencialista ou estática, o nacionalismo defendido por Hélio Jaguaribe era historicamente transitório:

Paradoxalmente, o nacionalismo é antinativista e antifolclórico. Não significa isso o repúdio cultural às nossas tradiçốes nem a perda de sensibilidade para as contribuições da arte popular. Significa, apenas, que tais contribuições irão passando da vida para o museu, que nós as incorporamos como compreensão do passado e não como formas aprisionadoras de nosso devenir. (JAGUARIBE, 1958b, p. 55)

Para Hélio Jaguaribe, não se poderia confundir nacionalismo com nacional:"[...]é indispensável elucidar todos os equívocos tendentes a confundir com o nacionalismo o fato de serem nacionais os agentes ou recursos empregados para a obtenção de um fim qualquer”. (JAGUARIBE, 1958b, p. 52). À guisa de exemplo, o isebiano utiliza a questão do petróleo brasileiro. Para o autor, o que torna a política petrolífera nacionalista não é o fato de termos uma empresa nacional gerindo a extração e produção (a Petrobrás), porém, o fato do petróleo brasileiro estar sendo gerido da melhor forma possível em prol da economia do país.

A medida em que o apoio à Petrobras decorra mais da circunstância de ser uma empresa nacional ou um monopólio do Estado do que o mais eficiente instrumento para atender às nossas necessidade petrolíferas, marca a distinção entre o equivocado nacionalismo de meios e o nacionalismo de fins. (JAGUARIBE, 1958b, p. 53).

Jaguaribe imprime um caráter "sistemático” e "global” desta categoria, pois se o desenvolvimento é um fenômeno que deve atingir todas as dimensôes da sociedade, o nacionalismo não pode ser medidas esparsas, ou isoladas, característica própria do intitulado "nacionalismo de meio" que não pensa na totalidade. Para o isebiano, uma das funçốes do nacionalismo é integrar politicamente a comunidade. Desta forma, o autor retira esta categoria das vontades e posiçóes políticas individuais, sendo resultado de uma política 
planejada e "total", que abarcasse as soluçôes para as contradiçôes sócio-econômicas que vivessem todos os grupos sociais. Portanto, uma visão mecânica e formal do nacionalismo não o levará a depreender as condiçóes singulares do país para estabelecer um padrão próprio de desenvolvimento. Jaguaribe cita que na "perspectiva mecânico-formal" o modelo de desenvolvimento do Brasil seguiria padróes internacionais, ao invés de superar o atual modelo econômico irá, pelo contrário, aprofundar o modelo agro-exportador, através da orientação "mecânica" de aumentar a produção sem superar as contradiçôes macro do país: "O modelo econômico conveniente ao Brasil, portanto, não será o que, pura e simplesmente, nas atuais condiçôes do país e do mundo, lhe proporcione maior produtividade marginal". (JAGUARIBE, 1958 b, p. 61). Neste termo, o autor diferencia o crescimento econômico de desenvolvimento.

Sendo assim, é insuficiente para Jaguaribe que o desenvolvimento seja apenas uma ideologia de classe, nestas condiçốes prevalecerão os interesses de classe e não do próprio desenvolvimento, causando inevitavelmente uma aproximação entre os setores "dinâmicos" e "estáticos" de cada classe, e por outro lado, gerando uma contradição entre as classes sociais: "[...] e a solidariedade de classe alia o capitalista produtivo aos improdutivos; as garantias de emprego [...] a remuneração [...] passam a constituir objetivo primeiro e básico, em lugar de ser decorrência do desenvolvimento" (JAGUARIBE, 1958 b, p. 64). Desta forma, para se considerar nacionalista, a ideologia do desenvolvimento deve ser também autêntica, pois o nacionalismo teria uma premissa agregadora dos grupos sociais de uma nação.

As direções que esta obra segue têm um sentido básico de dirimir as "polêmicas" contemporâneas ao autor que o mesmo julgava inócuas para o desenvolvimento. Um dos principais embates era entre os que defendiam a gestão estatal e os que defendiam a sua privatização.

[...] de um lado, quase toda a grande imprensa, a maioria dos sindicatos patronais e diversos congressistas, denunciando a imoderada intervenção do Estado na órbita econômica [...] de outro lado, a maioria dos sindicatos de empregados e muitos parlamentares, defendendo a intervenção econômica do Estado, sustentam a necessidade de expandir a gestấo pública a todos os setores estratégicos [...]. (JAGUARIBE, 1958b, p. 66).

Apesar da polêmica, a tendência do governo JK na época era expandir a desestatização de estradas de ferros, estaleiros e portos. Jaguaribe aponta o caráter "deslocado" desta polêmica diante dos fatos concretos que caminhavam apenas um uma direção. Porém, o que de fato tonificava o debate era a crescente campanha em torno da participação de capital estrangeiro no setor petrolífero. Cabe lembrar que o Estado brasileiro tinha o monopólio 
do petróleo em solo nacional desde a promulgação da lei que criava a Petrobrás em outubro de 1953. Importante ressaltarmos que a análise realizada por Hélio Jaguaribe foca na dimensão nacional da iniciativa privada e não no capital estrangeiro em si. "[...] sendo o capital estrangeiro matéria distinta da forma pela qual se encare a iniciativa privada."(JAGUARIBE, 1958b, p. 68).

$\mathrm{O}$ autor amplia sua análise para as raízes sociológicas da relação entre o indivíduo e o Estado. A conclusão que chega é que se trata de um ponto que não configura controvérsia para a ciência política, a verdadeira questão tratava-se do debate sobre a gestão econômica, ou seja, se a privacidade incluída em todos os regimes deveria abarcar ou não o direito à propriedade e gestão pública. Nestes termos, o isebiano leva o rumo da análise para um comparativo entre capitalismo e socialismo. Jaguaribe afirma que a "marcha histórica" dos dois regimes se encaminha para uma convergência, pois ambos se modificaram e se afastaram de suas premissas clássicas. Ao ponto de o autor afirmar que "não há mais países capitalistas e socialistas" a rigor (JAGUARIBE, 1958, p. 87). Nessa perspectiva, havia um socialismo ao preconizar que as atividades sociais são funções sociais e um capitalismo na preservação da acumulação capitalista em prol do desenvolvimento.

\section{CLASSES SOCIAIS, IDEOLOGIA E DEMOCRACIA}

Jaguaribe não nega a existência de conflitos sociais no Brasil. Contudo, ele não os enxerga da mesma maneira que seus contemporâneos ligados ao comunismo ou ao trabalhismo, se estes davam protagonismo aos trabalhadores no processo de desenvolvimento, Jaguaribe desenvolve uma interpretação histórica do Brasil que resulta na defesa do protagonismo da burguesia como agente modernizador. Para o autor, a luta fundamental não seria entre as classes, mas entre os setores internos delas, que poderiam ser dinâmicos ou estáticos. Logo, o que haveria de ser superado não era a composição social, mas a estrutura faseológica do Brasil. Nesta modalidade de conflito, a tensão se daria entre aqueles acomodados no seu momento histórico e os obsoletos.:

Em outros dois livros do autor, publicados durante sua atuação no ISEB, aparece de forma mais clara alguns pontos que marcam a relação que ele estabelece entre interpretação e compreensão do processo histórico e a formação de projetos políticos para o país a partir de uma ideologia nacionalista. São eles: O problema do desenvolvimento econômico e a burguesia nacional (JAGUARIBE, 1958c) e Condiçóes Institucionais do desenvolvimento (JAGUARIBE, 1958a).

Para Jaguaribe (1958a) (1958c), o Brasil teria passado por três fases na sua história, cada qual correspondente a uma determinada estrutura-tipo A 
primeira teria permanecido desde o descobrimento do Brasil até século XIX. Seu perecimento teria começado por volta de 1850 , com a progressiva substituição de mão de obra escrava pela assalariada. Para oautor, a condição colonial de um país seria definida por duas principais características, sendo elas a heteronomia, na qual: “...o processo econômico é provocado por fatores externos à própria comunidade, quer dizer, é determinado pelas suas relaçóes de intercâmbio.” (JAGUARIBE, 1958b, p. 14) e a exogenia, que se definiria pelo acúmulo de renda ocorrer apenas na metrópole, privando a colônia de seus benefícios.

O trabalho escravo, característico da estrutura-tipo colonial, não permitiria o processo interno de acumulação de renda, pois não haveria salário e logo não se faria possível sua troca por consumo. "Não havendo pagamento de salários, a sociedade cresce por justaposição de riquezas. A uma fazenda de café se acrescenta outra fazenda de café, mas não há circuito de investimento, relação de investimento, produto e poupança.” (JAGUARIBE, 1958 a p. 15). A única acumulação que existira em território nacional seria a de riqueza, uma vez que a de renda se faria no exterior " [...] no processo de venda de escravos, de compra e de revenda do produto primário importado pela comunidade colonial” (JAGUARIBE, 1958a, p. 15)

Segundo o autor, a transição de uma dessas fases históricas do processo econômico brasileiro para outra necessitaria a conjugação de um fator externo com um interno. Assim, amudança da estrutura-tipo colonial para a semicolonial seria resultado da extinção do tráfico e a consequente alteração do regime de produção para o de mão de obra assalariada.

A segunda estrutura-tipo, a semicolonial, teria durado de 1850 até a crise do café nos anos 1920. A crise de 1929 seria responsável por agravá-la. Nela "...o Brasil se depara com a incapacidade de continuar financiando, com o produto da sua exportação cafeeira, todas as necessidades do seu consumo.” (JAGUARIBE, 1958a, p. 16), Nesta estrutura-tipo persistiria a heteronomia, mas a exogenia tenderia gradualmente a desaparecer, pois uma vezimplementada a mão de obra assalariada, surgiria o mercado interno consumidor.

A partir dos anos 1930, o Brasil estaria entrando em uma terceira fase de transformação. Nas fases colonial e semicolonial as classes dirigentes produziam e vendiam sobretudo café, pois era o produto que apresentava maior taxa de rendimento por causa das condiçóes naturais que favoreciam sua produtividade. Contudo, a crise deste modelo teria forçado o país a investir no mercado interno. O Fator externo que teria possibilitado o avanço para essa etapa foi a crise cambial, enquanto o interno foi a formação de um mercado voltado para o país. 
Uma vez que o principal produto de exportação brasileiro era o café, ele não aumentaria seu consumo externo de acordo com o aumento per-capita das naçóes compradoras. O único fator que influiria no aumento de sua compra seria o crescimento vegetativo da população dos países, inferior às necessidades de exportação do Brasil. Ao mesmo tempo, a população brasileira estaria crescendo, assim como suas necessidades de consumo. As divisas adquiridas pela venda de café não seriam suficientes para suprir esta demanda. Esse problema teria se agravado ainda mais com a crise de 1929, obrigando o Brasil a produzir internamente os produtos acabados que não conseguia mais adquirir no exterior. Adicionou-se a isso a crise cambial, que criou obstáculos para a entrada de produtos estrangeiros concorrentes. A solução foi a industrialização do país, pela diversificação da lavoura, voltada a partir daí também para o mercado interno.

Para Hélio Jaguaribe, o Brasil estaria nos anos 1950 em uma fase na qual a sua estrutura-tipo subdesenvolvida se encontraria em momento de transição entre a situação colonial e a situação autônoma. O país teria capacidade de desenvolver-se e superar o momento de transição, contudo, haveria obstáculos. Os principais problemas seriam as características subdesenvolvidas do Brasil: baixa renda per-capita em relação aos outros países, diferenciação do consumo entre as classes e a predominância da produção primária sob a produção elaborada. Em suma, para seu país se tornar desenvolvido e autônomo, o autor acreditava que ele precisaria primeiro que o setor agrário-exportador deixasse de ser maior e mais importante do que o setor industrial.

O fato de o Brasil não ter à época uma indústria desenvolvida manteria o país atrasado. Sua situação enquanto semicolonial se daria justamente por manter características arcaicas que o impediriam de ser autônomo. Para Jaguaribe:

A situação colonial é uma situação que independe das relaçốes políticas; ela é determinada, sobretudo, pela situação econômica, social e cultural do país dado, em relação a outros que, ainda que sem a inculcação política expressa da condição de metrópole, atuam para com este país tal como se o fossem. (JAGUARIBE, 1958c, p. 20).

Jaguaribe parece entender especificamente no trecho acima a política como administração e domínio direto do território. Portanto, ele define a situação colonial como, estar-se submetido a uma metrópole por imposição de uma lógica econômica e cultural, independente de se pertencer oficialmente ao território dominador. O Brasil tinha como principal consumidor e exportador os EUA, sendo mais de $50 \%$ do comércio exterior nacional feito com esse país. Para Jaguaribe isto "[...] mostra que os Estados Unidos da América, independentemente de vínculos políticos, funcionam como um 
país semi-metropolitano em relação ao Brasil.” (JAGUARIBE, 1958c, p. 22). Portanto, os EUA seriam a semi-metrópole da semi colônia Brasil.

Enquanto país semicolonial, o Brasil já teria começado a operar em função do seu mercado interno e possuiria processos internos de capitalização que começaram a permitir oseu crescimento interno, com investimentos próprios. Ele se encontraria em uma etapa na qual teria tendência progressiva de diminuição de dependência do comércio exterior, com crescimento da produção interna. Entretanto, a etapa em que o país se encontraria não o privaria de ter problemas a resolver, sendo os principais a crise no comércio exterior e a diferença entre oferta de bens e serviços (energia elétrica, combustíveis, serviços de base e transportes).

De 1947 em diante o equilíbrio entre importaçóes e exportaçóes teria começado a se romper. A crise aberta daí em diante seria a segunda etapa da crise cambial: "O país não tem mais capacidade de financiar as importações de equipamentos de que necessita para produzir os produtos acabados, de que por sua vez necessita para atender ao seu mercado interno.” (JAGUARIBE, 1958c, p. 36) Enquanto o Brasil continuasse a exportar majoritariamente produtos primários não haveria maneira de aumentar divisas para reverter este quadro.

A infraestrutura nacional seria inadequada para esta fase. A estrutura do país não teria se modificado o suficiente desde os anos 1930, fato que poderia ser comprovado pela relação entre investimento total e rendimento serem muito baixa entre setor de transportes e o de produção de serviços públi$\cos$ (apenas 4.4\% em dados trazidos pelo próprio). Isto tornaria esses setores pouco atrativos para o investimento do capital privado. O problema poderia ser superado se a industrialização brasileira se acirrasse ainda mais. $\mathrm{Na}$ etapa em que o Brasil se encontraria, a maneira de vencer os gargalos do desenvolvimento, seria que ele passasse "...a produzir internamente os equipamentos que até agora vínhamos importando.” (JAGUARIBE, 1958c, p. 42). Nesta etapa de transição, seria preciso não só produzir nacionalmente as próprias fábricas para atender o mercado interno, mas também seus equipamentos. Isso permitiria o equilíbrio da balança comercial brasileira e o consequente avanço do desenvolvimento.

Segundo a análise de $O$ problema do desenvolvimento econômico e a burguesia nacional (JAGUARIBE, 1958a), o processo de desenvolvimento que o Brasil passou desde 1930 teria sido responsável por gerar uma mudança na sua estrutura social. De uma classe dirigente de latifundiários com relação predatória e especulativa com a terra, passou-se a uma burguesia diversificada, com setores industriais e preocupados com o mercado interno. Formou-se também o proletariado e uma classe média diversificada. Esta 
última, teria deixado de se empregar apenas no funcionalismo público para ocupar também cargos técnicos e administrativos nos novos empreendimentos que surgiram.

No entanto, este processo econômico e social não teria evolução política correspondente. A estrutura do Estado brasileiro seria basicamente a mesma de antes de 1930, o que dele faria um "Estado Cartorial” (JAGUARIBE, 1958a, p. 51). O autor define tal conceito da seguinte maneira:

Estado Cartorial é o Estado que resulta de uma situação em que o jogo do poder se faz em termo de política de clientela. A política de clientela, por sua vez, consiste no processo pelo qual se constitui o poder, uma comunidade em que existe um grupo detentor dos meios de produção rural, que são os latifundiários, apoiado por um grupo mercantil dos centros urbanos e em torno dos quais gira necessariamente toda a possibilidade de emprego, toda a possibilidade de concessão de favores, de sorte que as clientelas se organizam em forma piramidal, através de contratos tácitos ou relaçôes semelhantes, para assegurar uma composição política correspondente a essa mesma composição econômica. (JAGUARIBE, 1958a, p. 51)

Nesta fase do Brasil, haveria um desarranjo entre o econômico-social e a estrutura do Estado-nacional. Este seria responsável por conservar uma contradição: a classe industrial teria a propensão de assumir o comando do processo econômico e social, mas o Estado brasileiro era de tipo agrário, dominado por coronéis que conservavam um poder excessivo.

A manutenção do Estado Cartorial se deveria, em partes, ao fato de que as classes no Brasil seriam vítimas de uma confusão ideológica geral. O Proletariado seria vítima de equívocos que o levariam ao assistencialismo e o culto de um líder carismático. No entanto, o que ele necessitaria de fato seria a expansão do desenvolvimento econômico, pois é a baixa produtividade que não permite a remuneração adequada da classe.

Já a Classe média, era seduzida por movimentos moralistas como o lacerdismo. Para Jaguaribe, este tipo de norma de conduta cultivada pela classe média seria próprio do meio rural, devendo tornar-se ultrapassado na fase em que o Brasil estaria. $\mathrm{O}$ autor compreendia que a classe média não queria perder privilégios e nem símbolos de diferenciação social que permitissem seu contraste em relação aos proletários. Em suas palavras:

E cultiva preconceitos anti-industriais e anti-proletários, parcialmente motivados pelo fato de que na evolução de uma sociedade agro-pastoril para uma sociedade industrial, tendem a desaparecer as pequenas sutilezas da hierarquia social, em torno do qual tanto se aferra a classe média. (JAGUARIBE, 1958a, p. 54) 
O que de fato a classe média necessitaria é do desenvolvimento. Com o incremento de parques industriais ela seria empregada em cargos técnicos e administrativos, o que permitiria, inclusive, o acesso de mais pessoas ao lugar da pequena burguesia. Isso também retiraria a classe média do lugar marginal que teria em seu país. Com a industrialização, a classe média poderia se inserir de fato no processo produtivo, enquanto em uma sociedade agrária permaneceria sem lugar.

O problema da burguesia - classe vista como protagonista no processo estaria no fato de que seu setor mercantil continuaria na liderança. Quando o interesse da burguesia industrial fosse atendido, o de todas as demais classes também seriam. Hélio Jaguaribe era leitor de Joseph Schumpeter (1961). Deste autor, ele retirou sua compreensão de que oempresário capitalista é o ator responsável por trazer a inovação:

A ordem capitalista, da maneira como está materializada na instituição da empresa privada, prende eficientemente o capitalista ao seu trabalho" [...] O mesmo sistema que, em uma determinada época, condiciona os indivíduos e as famílias que formam a classe burguesa, seleciona também, ipso facto, os indivíduos e famílias que ascenderão nesta classe ou dela serão excluídos. Esta combinação de função estimuladora com função selecionadora não é absolutamente coisa simples. [...] "O homem que ascende, em primeiro lugar, à classe dos homens de negócio e, depois, dentro dela se mostra indivíduo capaz, ascenderá com toda a probabilidade até onde o puder levar sua capacidade, simplesmente porque, neste esquema, ascender a uma posição e nela atuar bem é, ou sempre foi, de maneira geral a mesma coisa. Este fato, tão frequentemente obscurecido pela tentativa autoterapêutica dos fracassados para negá-lo, é muito mais importante para a apreciação da sociedade capitalista e da civilização que ela cria do que tudo que se possa recolher da teoria pura do sistema capitalista. (SCHUMPETER, 1961, p. 95)

Tanto Schumpeter quanto Jaguaribe compreendem uma divisão social entre classes dirigentes e dirigidas na qual cabe à primeira empreender para levar o desenvolvimento para as demais. Em ambos os autores quem cumpre este papel é o empresário capitalista, durante o processo de desenvolvimento, a relação entre as classes sociais precisaria ser de cooperação. $\mathrm{O}$ autor austríaco apresenta esta conclusão a partir de crítica que faz ao conceito de luta de classes de Karl Marx:

Para qualquer mente não deformada pelo hábito de orar pelo rosário marxista, deve ser evidente que a relação entre as classes, em tempos normais, é, principalmente, de cooperação e que qualquer teoria contrária deve basear-se, em grande parte, para verificação, em casos patológicos. Na vida social, antagonismo e colaboração apresentam-se juntos e são, de fato, inseparáveis, exceto em casos muito raros. (SCHUMPETER, 1961, p. 29) 
Jaguaribe recepcionou estas ideias para o Brasil,adequando-nas à situação nacional. Para ele, haveria uma "Missão da Industria nacional" (JAGUARIBE, 1958c, p. 55). Partindo do conceito de Ideologia tal como pensado por Karl Mannheim, Jaguaribe concluiu que a burguesia apresentaria as linhas de representatividade e de autenticidade do mesmo:

Pode-se chamar como representativa uma ideologia que efetivamente corresponde aos interesses situacionais do grupo de que ela é a expressão; pode-se chamar de autêntica a ideologia que realmente corresponde às necessidades da comunidade no momento dado. Ora, neste momento, aquilo de que realmente o país tem necessidade, que é a promoção do seu desenvolvimento econômico em termos de mobilização ótima dos fatores disponíveis no país, em função deste, é exatamente o que corresponde ao interesse da burguesia nacional. (JAGUARIBE, 1958a, p. 55 e 56)

$\mathrm{O}$ interesse da burguesia industrial representaria, portanto, o interesse de todas as classes: o desenvolvimento. Caberia a esta burguesia cumprir seu papel histórico de promovê-lo. Isso deveria ser feito a partir da formulação de uma Ideologia não só representativa da burguesia, mas autêntica do Brasil, uma vez que estaria de em harmonia com o interesse de todas as classes sociais. Angélica Lovatto (2010) elucida melhor este ponto:

No decorrer da análise do pensamento de Hélio Jaguaribe percebe-se claramente a reafirmação de que a representatividade e a autenticidade ideológica estavam presentes na burguesia industrial brasileira. Isso porque ela representaria o dinamismo econômico daquele momento, ou seja, a base moderna sobre a qual deveria se processar a reforma do Estado. Esta classe congregava todos os interesses situacionais e seria, por isso mesmo, a mais autêntica para conduzir, enquanto força dirigente, o desenvolvimento nacional. (LOVATTO, 2010, p. 104)

Como consequência de sua interpretação da História do Brasil e de suas leituras de Schumpeter e Mannheim, Hélio Jaguaribe acreditava que o desenvolvimento econômico, social, político e cultural do país seria alcançado via um processo de industrialização liderado pela burguesia. $\mathrm{O}$ resultado disto seria a ruptura do páis com todos os resquícios coloniais que o prenderiam, tornando-se autônomo em todos os campos. Recepcionando a obra de Ortega y Gasset (s.d.), Jaguaribe passou a enxergar não só o indivíduo, mas a própria nação como algo que se faz dentro de sua própria história.

Assim como propõe o filósofo espanhol, é tomando consciência das circunstâncias que a condicionam historicamente que é possível dar sentido para a vida. Mas, para obrasileiro, trata-se da vida do país e como o seu processo histórico o condiciona em determinado sentido no qual ele mesmo deve ser agente de sua mudança. A razão histórica passa a ter com Hélio Jaguaribe enquadramento nacional, fornecendo junto com a sociologia do 
conhecimento de Karl Mannheim aparato teórico-metodológico que pretendeu compreender o passado histórico do Brasil para lhe formular um projeto político adequado para o seu desenvolvimento e, consequentemente, sua emancipação.

Tal como o próprio nome de uma de seus livros propóe, o autor entende que para atingir o desenvolvimento seria preciso antes garantir certas condições institucionais para o mesmo. Estas ideias são fruto de recepção de outro trabalho de Karl Mannheim, desta vez Liberdade, poder e planificação democrática (MANNHEIM, 1972). O sociólogo húngaro pretendeu propor nesta obra um modelo de planificação que fosse o mesmo tempo democrático. Sua intenção era superar os excessos cometidos tanto pelo Capitalismo dos Estados Unidos da América e quanto pelo comunismo da União das República Socialistas Soviéticas. Para tal, Mannheim julgava ser importante não só modificar as estruturas econômicas de uma sociedade, mas também as políticas e culturais. Segundo ele:

Sem menosprezar a significação da estrutura econômica, salientaremos que, sem as modificaçóes correspondentes no plano político e cultural não há reformas satisfatórias. Cada vez mais se reconhece que a verdadeira planificação consiste na coordenação das instituiçóes, da educação, dos valores e da psicologia. Só quem puder ver as importantes ramificaçóes de cada passo isolado, poderá atuar com a responsabilidade exigida pela complexidade da época moderna. Nestas circunstâncias, um livro sobre a essência da planificação democrática deve tomar como tema a vida social em sua totalidade: novas instituições, homens novos, valores novos. (MANNHEIM, 1972, p. 17-18)

Partindo da inspiração mannheimiana de compreender e resolver os problemas de uma comunidade a partir da compreensão de todos os seus componentes, Hélio Jaguaribe propôs soluçôes para o caso brasileiro. $\mathrm{O}$ autor formulou então seu conceito de "institucional" com dois sentidos. No Sentido amplo, ele seria o próprio processo social. Nesta definição, seria institucional tudo que fosse construção social humana. Já no sentido restrito, ele seria:

Em sentido estrito, porém, o institucional se distingue do processo social global como o ato pelo qual, no processo global, a comunidade erige determinados valores como fins, determinadas normas como processo, e assim organiza entidades operativas para a consecução dos seus fins. (JAGUARIBE, 1958b, p. 39)

Haveria comprovação histórica da influência de ambos sentidos do conceito de institucional nos processos de desenvolvimento. $\mathrm{O}$ amplo se verificaria pela relação entre oprotestantismo calvinista e a formação do capitalismo. Já no sentido de instituiçóes como normas que ordenam o processo social, a principal seria o Estado moderno, tanto como agente quanto como norma. 
Para o autor, a diferença entre os dois conceitos de Instituição derivaria politicamente em duas concepções distintas do processo de desenvolvimento. Elas, por sua vez, seriam representadas por ideologias políticas que buscariam lhes dar sentido teórico. O conceito de Institucional no sentido amplo seria representado pelo liberalismo, concebendo então o desenvolvimento como decorrente da livre espontaneidade do meio social. Já o conceito estrito entenderia o desenvolvimento como fruto de ação diretora e configuradora do processo. As teorias que buscariam dar sentido a essa forma de compreender o processo de desenvolvimento seriam representadas pelas concepções de Estado interventor e diretor.

Para resolver este conflito entre opostos, Hélio Jaguaribe aplicou em Condiçôes Institucionais do desenvolvimento (JAGUARIBE, 1958a) o mesmo procedimento dialético que depois organizou $O$ nacionalismo na atualidade brasileira (JAGUARIBE, 1958b) como um todo. Apresentando ideias contrárias, ele as organizou enquanto tese e antítese e procurou superá-las a partir de uma síntese. Esta, por sua vez, incorporaria características das duas ao mesmo tempo em que avançaria para além delas. Assim como Mannheim (1972), Jaguaribe se esforçou nesse procedimento por oferecer uma terceira via para a resolução dos conflitos que marcavam o seu tempo, dando a esta o sentido de um caminhar histórico dialético. Nas palavras do autor:

Vale a pena, porém, observar que, historicamente, a controvérsia tende a ser superada, quer no nível teórico, quer no nível prático. Verificamos que diminui cada vez mais o número dos autores que propendem a defender uma posição liberal estrita, e paralelamente os que tendem a defender o dirigismo total." (JAGUARIBE, 1958a, p. 40)

A crítica de Hélio Jaguaribe ao liberalismo tem por base a percepção de tal corrente do pensamento como teoria abstrata, que pressuporia um homo economicus racional inexistente. Todavia, sua antítese - o dirigismo - também seria problemática, pois visaria esgotar o real pelo conceito (JAGUARIBE, 1958a, p. 41), impondo de cima para baixo políticas concebidas no plano intelectual. A solução do autor foi conciliar estes contrários, dando à síntese produzida o sentido de um caminhar histórico para determinada direção. Para Jaguaribe, seria o planejamento democrático que resolveria tal conflito, a partir da criação de uma teoria que correspondesse às exigências da história. Eis, para o autor, a principal condição institucional para o desenvolvimento:

Essa propensão a realizar, tanto na prática como na teoria, uma conciliação entre os princípios da espontaneidade e do dirigismo, quebrando o radicalismo anterior, representa a tendência, em nosso tempo, a conceber as condiçóes institucionais do desenvolvimento, como algo que deve ser organizado na forma de um planejamento democrático. Planejamento que não só induza os cidadãos a 
se autodeterminarem - reservando-lhes certa área de privaticidade no âmbito da qual funcionem, com a espontaneidade, os móveis psicológicos e sociais correntes -, mas também organize condiçóes e estímulos diretos e indiretos que levem ao desenvolvimento a se processar de acordo com a expectativa contida no plano. (JAGUARIBE, 1958a, p. 42)

Consequência da análise feita pelo autor das estruturas-tipo do Brasil, o país estaria em uma fase histórica na qual o desenvolvimento começaria a ter condiçóes materiais para ocorrer. Os principais fatores endógenos que permitiriam isso seriam o aumento do mercado, determinado pelo crescimento da população, e o enriquecimento per capita, responsável por expandir para o interior hábitos de consumo que antes estavam só em regiôes litorâneas. Já os principais fatores exógenos seriam as crises cambiais dos anos 1920 e dos anos 1940. A primeira teria forçado o abandono do antigo sistema produtivo agrário-exportador e a segunda teria forçado a produção de equipamentos para compensar as carências cambiais.

Contudo, todo o esforço econômico teria sido em vão se não ocorresse também a superação dos "pontos de estrangulamento" (JAGUARIBE, 1958a), a serem ultrapassados por marcos institucionais. Estes existiriam em quatro níveis: econômico, social, cultural e político. No nível econômico o ponto de estrangulamento seria o fato de que formação de poupança e de investimento não coincidiria com as necessidades da população, gerando desequilíbrio na oferta de serviços de bens e de infraestrutura. Para Jaguaribe este problema não é tão grave, pois tenderia a ser superado no longo prazo. Inclusive, o uso de capital estrangeiro não seria dispensável para tal.

No nível social, os pontos de estrangulamento seriam a tendência de manutenção de privilégios de classe e parasitismo social. Eles impediriam que a sociedade ganhasse sentido democratizante. Todas as classes (proletários, classe média e burgueses) sofreriam com o parasitismo. Proletários seriam reféns de um sistema político-jurídico que não era moderno e a classe média ficaria ociosa. Por sua vez, a burguesia continuaria com empreendimentos menos produtivos, exemplificado pelo autor com o açúcar do Nordeste, que só seria capaz de competir com o do Sul por ser subsidiado. Hélio Jaguaribe defende a democratização como necessária, sua ausência seria fator de estrangulamento social. O planejamento que deve ser feito na fase histórica que se abria para o Brasil deveria ser democrático, como o de Mannheim (1972). Apenas democratizando o país seria possível modernizá-lo:

No plano das nossas relações sociais, esses fenômenos de estrangulamento se apresentam em termos de permanência, além do período em que historicamente ainda eram compreensíveis, dos privilégios de classe, que tendem a enquistar-se em determinados sistemas de resistência e dificultam a horizontalização da de- 
mocracia brasileira, suscitando, ademais, um fenômeno extremamente grave, que é o parasitismo social. (JAGUARIBE, 1958a, p. 17)

Existiriam dois estrangulamentos da cultura, ambos criticados pelo autor por seus excessos. Como lhe é característico, Jaguaribe almejava sua síntese. Estes pontos seriam a alienação colonial, responsável por produzir a implantação mecânica de lógicas exógenas, e o nativismo primário, que engessaria a cultura brasileira. O problema do último é que as características brasileiras mantidas pelo subdesenvolvimento são postas como inalteráveis. $\mathrm{O}$ alvo da crítica de Jaguaribe é a coexistência de duas mentalidades. Uma, de origem colonial perceberia tudo no Brasil como inferior ao que vem de fora. Outra, teria como pressuposto um conceito de nação e de cultura essencialistas e conservadores, sem pensá-los como inseridos em uma dinâmica histórica que os modificaria. Jaguaribe compreende que se afirmar como brasileiro é afirmar sua Nação como uma igual às demais, entendendo que, como sua História é diferente e sua estrutura-tipo única, as ideias que teriam determinado sentido em outros países, no Brasil seriam recepcionadas e dialogariam com a realidade tal como aqui ela se encontra. Os problemas de uma mentalidade alienada são expostos pelo autor na passagem abaixo:

A alienação leva o brasileiro a pensar como se fosse inglês, francês, ou americano, esquecido de que, se os instrumentos teóricos da cultura ocidental se caracterizam por sua 'transferibilidade', nunca é transferível a perspectiva, sempre própria de cada pessoa, de cada povo e de cada momento, e que, portanto, toda transplantação cultural que consigo acarrete a transferência de perspectiva, falseia a possibilidade de utilização dessa cultura, desse instrumento teórico, por contrabandear uma perspectiva que a torna inautêntica. (JAGUARIBE, 1958a, p. 45)

Para que as condições institucionais do desenvolvimento fossem atingidas seria necessária a agência de setores esclarecidos, capazes de instruir a burguesia sobre o processo que o Brasil estaria passando, tornando-a ciente de seu papel histórico de encabeçar o desenvolvimento. Mannheim (1972) nomeia este tipo de elite de Intelligentsia. Hélio Jaguaribe concorda com o sociólogo húngaro que sem este setor e sem ideologia não há condiçóes institucionais para o desenvolvimento:

Para poder instaurar as condições institucionais que tornarão possível a aplicação dos planos e farão do planejamento a função precípua do Estado, é indispensável a mobilização ideológica, em virtude da qual os diversos setores que compõem a sociedade brasileira conciliem o seu próprio interesse com os objetivos do plano. (JAGUARIBE, 1958a, p. 49) 
A partir de recepção da obra Ideologia e Utopia de Mannheim (1987), Jaguaribe compreende ideologia como "[...] uma racionalização de expectativas de organização da sociedade, decorrente da posição situacional dos membros dessa sociedade." (JAGUARIBE, 1958a, p. 49). Na fase em que o Brasil se encontraria, haveria correspondência dos interesses das classes com as condiçóes institucionais necessária para o desenvolvimento, ambos se beneficiariam do aumento de produtividade. Portanto, uma ideologia voltada a instruir a burguesia industrial seria mais representativa e a mais autêntica para o Brasil, uma vez que teria conexão lógica e factual entre suas formulações e a classe que representa as exigências de sua comunidade na fase em que se encontraria o país.

A educação ideológica faria a burguesia brasileira ter consciência de seu papel no desenvolvimento, se convertendo de burguesia latifundiária e agrário-exportadora para “[...] burguesia nacional e progressista.” (JAGUARIBE, 1958a, p. 52). Do mesmo modo, o problema de reorganizar o Estado para deixar de ser cartorial e parasitário, tornando-se funcional, seria “...um problema de educação e organização ideológica.” (JAGUARIBE, 1958a, p. 53). Tal como propóe Angélica Lovatto:

Construir uma ideologia desenvolvimentista significava, para Jaguaribe, construir uma ideologia nacionalista. Esta construção implicava na "criação de uma sociedade desenvolvimentista e o desencadeamento de condiçóes" que propiciassem "a superação do subdesenvolvimento econômico" e estivessem "essencialmente vinculados à ideia de planejamento. (LOVATTO, 2010, p. 109)
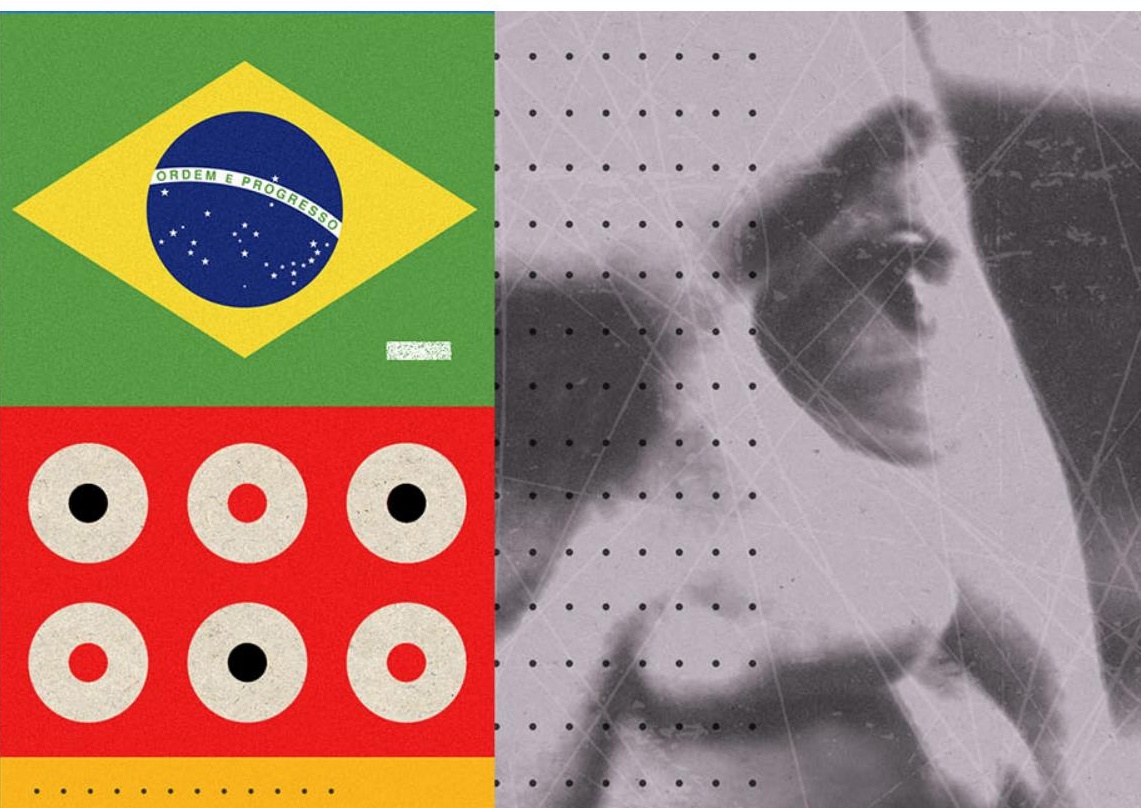
Os outros pontos de estrangulamento verificados estariam no nível político, representados pelo Estado Cartorial e pela política de clientela. As duas estruturas existiriam em simbiose, uma alimentando a outra e impedindo igualmente que se tenha um Estado hábil, independente de classes improdutivas. Também a partir da Ideologia que Hélio Jaguaribe tentou propor uma superação dos pontos de estrangulamento políticos, afirmando que as mudanças estruturais precisam ser também democratizantes. Seria do interior de um regime democrático ajustado aos valores culturais brasileiros que sairia a fórmula que reajustaria o Estado às forças dinâmicas capazes de conduzir o processo social.

O autor percebe a ascensão de uma nova forma de fazer política após a complexificação da sociedade e seu crescimento vegetativo. Estas teriam impedido que a relação entre político e eleitor fossem meramente clientelistas, fazendo emergir a "política ideológica" (JAGUARIBE, 1958a, p. 30). Hélio Jaguaribe a define como aquela que se oporia à política de clientela e “[...] em lugar de estabelecer uma barganha interindividual ou intergrupal do favor pelo voto, estabelece uma relação de orientação entre os interesses situacionais de determinado grupo ou de determinada classe e as formulações que convém a esse grupo e a essa classe. " (JAGUARIBE, 1958a, p. 30). O que o autor pretendia com essa nova forma de fazer política era aplicar os critérios de representatividade e de autenticidade da Ideologia às eleições. Determinada classe, que se beneficiaria de determinado programa, votaria em um candidato que o representasse. No entendimento de Angélica Lovatto (2010), a questão política seria o problema fundamental a ser resolvido ea política ideológica seu método:

\begin{abstract}
Registre-se que, na hierarquia dos problemas, a questão política aparece sempre em primeiro lugar, ou seja, como a condição essencial para o desencadeamento dos outros fatores. Aqui se encontra uma das determinantes fundamentais levantadas por Jaguaribe para o encadeamento das soluçóes nacionais: a necessidade da manutenção do que chama de política ideológica, em torno da qual a sociedade se mobilizaria como substituta corretiva da política de clientela. (LOVATTO, 2010, p. 103)
\end{abstract}

\title{
CONSIDERAÇÕES FINAIS
}

Tal como já foi exposto aqui anteriormente, $O$ Nacionalismo na atualidade brasileira (JAGUARIBE, 1958b) é organizado inteiramente pela exposição do conflito de teses contrárias para tentar propor a superação destas. Em algumas obras anteriores de seu período de atuação no ISEB, Hélio Jaguaribe já demonstrava não ser totalmente contrário à entrada de capital externo para 
auxiliar no desenvolvimento nacional. Em resposta a Jorge Martins Rodrigues na sessão de debates de $O$ problema do desenvolvimento e a burguesia nacional (JAGUARIBE, 1958c) o autor já defendia que a melhor forma de investimento estrangeiro para o Brasil seria a de empréstimos externos, pois eles permitiriam a permanência dos lucros no país e sua consequente acumulação de renda. O motivo principal apresentado pelo autor é que, na fase em que o Brasil se encontrava, ele não teria poupança suficiente para fazer sozinho o seu processo de desenvolvimento.

Ao analisar a questão do Petróleo, Jaguaribe apresenta em $O$ Nacionalismo na atualidade brasileira (JAGUARIBE, 1958b) que:

[...]o que torna nacionalista a atual política do petróleo não é o fato de a Petrobrás ser uma empresa do Estado brasileiro, dirigida por brasileiros natos, etc.. Em tese, a política nacionalista do petróleo poderia ser realizada pela Standard, ou qualquer outra empresa, desde que, concretamente, na situação do país, essa fosse a forma mais eficaz de explorar o petróleo brasileiro e proporcionar à economia nacional o pleno uso e controle de tal matéria-prima. (JAGUARIBE, 1958b, p. 52).

Segundo Angélica Lovatto (2010), o que o autor pretendia com tal assertiva era mediar as posiçôes contrárias, defendendo que o uso da capital estrangeiro não era intrinsicamente ruim, desde que seus efeitos espoliativos fossem controlados. Se era erro dos cosmopolitas subestimar a capacidade de desenvolvimento autônomo do país, os nacionalista se equivocavam ao exagerá-la. Uma vez que Hélio Jaguaribe defendia um nacionalismo pragmático, caberia:

[...] utilizar os meios que fossem necessários, independentemente da origem de seus agentes - mesmo os estrangeiros - para alcançar um fim: o desenvolvimento brasileiro. Neste texto, portanto, era reiterada pelo autor a defesa da utilização do capital estrangeiro como corretivo eficiente para a insuficiência de recursos internos do país. (LOVATTO, p. 141 e 142)

O contexto histórico e o clima interno do Instituto certamente não foram favoráveis às ponderações de Jaguaribe. Cinco anos antes da publicação do livro o país havia encerrado a Campanha do Petróleo é nosso com a criação da Petrobrás, empresa estatal portadora do monopólio da exploração do combustível fóssil. Segundo Nelson Werneck Sodré em $A$ verdade sobre o ISEB (SODRÉ, 1978), Jaguaribe teria sido alvo de campanha difamatória encabeçada por Alberto Guerreiro Ramos dentro do instituto. Guerreiro Ramos teria levado cópia ainda não publicada do livro $O$ nacionalismo na atualidade brasileira (JAGUARIBE, 1958b) para a diretoria da União Nacional dos Estudantes (UNE), apresentando- o como traidor da causa nacionalista 
interessado em entregar o petróleo brasileiro para o capital internacional. Esta tensão também teria se refletido no Instituto, dividindo as opinióes dos seus membros entre os dois lados envolvidos. Por fim, Hélio Jaguaribe acabou por escolher se retirar do ISEB. Encerrava-se então a militância do intelectual dentro do instituto que ele mesmo ajudara a construir.

Fazendo um balanço do nacionalismo de Hélio Jaguaribe durante sua atuação no IBESP E NO ISEB, podemos afirmar que ele se apresentava como um fenômeno histórico de consciência de uma nação em relação à sua preservação e desenvolvimento. Jaguaribe verificou que a fase de desenvolvimento de uma nação sucede uma compreensão ampla dos problemas que estrangulam o seu crescimento. Tais questóes se apresentariam de forma singular em cada país, o que torna a consciência nacionalista construtora de um pensamento genuinamente nacional.

O projeto de desenvolvimento proposto pelo intelectual era amplo, mais do que um programa econômico era um projeto de nação que articulava diversas áreas da sociedade. Para tal empreitada era necessária a participação dos setores mais modernos de todas as classes sociais. $\mathrm{O}$ argumento utilizado para essa cooperação de classes baseava-se na afirmação de que os interesses "situacionais" de cada classe convergiam para uma política desenvolvimentista, que aumentaria a renda nacional e o acesso das classes a ela através da maior produtividade. O Estado teria um papel fundamental de promover o desenvolvimento e executar esse amplo projeto de modernização nacional que passava a direcionar recursos para áreas prioritárias e a regular a iniciativa privada. Para tal, o Estado deveria ser uma esfera incólume aos "grupos de pressão" privados da sociedade, portanto, sua reforma se fazia fundamental. Hélio Jaguaribe se preocupava em estabelecer seu projeto de desenvolvimento no campo da "racionalidade técnica" para alcançar um consenso das classes sociais, tão caro ao autor, e evitar as adjetivações que o jogassem em um dos pólos das polêmicas entre "nacionalistas" e "entreguistas", marcadas pelo acirramento de bandeiras ideológicas.

O isebiano tentou passar pelo "meio" se afastando das radicalizações. Ao afirmar em 1958 que o papel do nacionalismo era de agregar harmonicamente os distintos setores sociais

de uma comunidade, estava criticando as posições nacionalistas que mais dividiam do que produziam um consenso na sociedade, uma maioria. Neste sentido tentou qualificar e legitimar o seu nacionalismo a partir do seu projeto de desenvolvimento, ao passo que criticava as posiçóes nacionalistas rasas, sem um projeto profundo e com um apelo pueril pelo que era nacional e não necessariamente bom para a nação. Nesta perspectiva, ele definiu o nacionalismo em duas categorias: "nacionalismo de meios" e "nacionalismo 
de fins”, entre as quais se incluía na segunda categoria. Portanto, o nacionalismo de Jaguaribe era coerente com o seu projeto de desenvolvimento nacional marcado pela necessidade de uma cooperação de classes, pretendendo aproximar setores mais liberais e mais estatizantes. Era pregado ao mesmo tempo o importante papel da iniciativa privada e da função primordial do Estado no planejamento.

\section{Nota}

1 Tal como veremos mais à frente neste trabalho, Hélio Jaguaribe era bastante crítico da visão que os liberais do período tinham sobre como deveria ser gerida a política e a economia. Segundo o autor, a posição neoclássica seria ultrapassada já em sua época pois não bastaria a burguesia tomar papel no desenvolvimento, mas necessitaria da ação ativa do Estado neste processo.

\section{Referências bibliográficas}

BIELSCHOWSKY, R. Pensamento econômico brasileiro: o ciclo ideológico do desenvolvimentismo. 5. ed. Rio de Janeiro: Contraponto, 2004.

CANNONE, H. M. P. Passado, desenvolvimento e futuro: a relação entre História e Política na obra de três intelectuais do ISEB. Dissertação (Mestrado). Instituto de Estudos Sociais e Políticos, Universidade do Estado do Rio de Janeiro. 2018, $114 \mathrm{f}$.

CAPUTO, A. C. \& COSTA, G. M. M. Memórias do Desenvolvimento. Ano 3, n. 3. Rio de Janeiro: Centro Internacional Celso Furtado de Políticas para o Desenvolvimento, 2009.

DRAIBE, S. Rumos e Metamorfoses. Estado e industrialização no Brasil (1930-1960). Rio de Janeiro: Paz e Terra. 2004.

FIORI, J. L. (org.). Estados e moedas no desenvolvimento das nações. Petrópolis, Vozes, 1999.

FONSECA, P. C. D. Desenvolvimento: a construção do conceito". Texto para Discussão IPEA, n.2103, julho, 2015.

GUIMARÃES, C. A. C. Vargas e Kubitschek: a longa distância entre a Petrobrás e Brasília. In: CARVALHO, M. A. R. (Org.). República no Catete. Rio de Janeiro: Museu da República, 2001.
INSTITUTO BRASILEIRO DE ECONOMIA, SOCIOLOGIA E POLÍTICA (IBESP). Para uma política nacional de desenvolvimento. In: SCHWARTZMAN, Simon (sel. e introd.). O pensamento nacionalista e os "Cadernos de Nosso Tempo". Brasília: UNB/Câmara dos Deputados, 1981. Pág.171-273.

JAGUARIBE, H. Condições institucionais do desenvolvimento. Rio de Janeiro: Ministério da educação e cultura, 1958.

JAGUARIBE, H. O nacionalismo na atualidade brasileira. Rio de Janeiro: Ministério da educação e cultura, 1958.

JAGUARIBE, H. O problema do desenvolvimento econômico e a burguesia nacional. 2 ed. São Paulo: Fórum Roberto Simonsen, 1958.

JAGUARIBE, H. A crise brasileira. In: SCHWARTZMAN, Simon (org). O Pensamento Nacionalista e os "Cadernos de Nosso Tempo". Brasília: Editora Universidade de Brasília. 1981.

JAGUARIBE, H. "Usina de altos estudos". Insight inteligência. Rio de Janeiro, n. 75, out-nov-dez 2016. p. 81-90.

JUDT, Tony. Pós-guerra: uma história da Europa desde 1945. Rio de Janeiro: Objetiva, 2007. 
LACERDA, Carlos. O poder das ideias. Rio de Janeiro: Editora Record. 1965.

LOVATTO, Angélica. A utopia nacionalista de Hélio Jaguaribe: os tempos do ISEB. São Paulo: xamã; Arte escrita, 2010.

LYNCH, C. E. C. Por que pensamento e não teoria? A imaginação político-social brasileira e o fantasma da condição periférica. Revista Dados, Rio de Janeiro, v. 56, n. 4, pp. 727-766, 2013.

MANNHEIM, K. Ideologia e Utopia. 4. ed. Rio de Janeiro: Guanabara, 1986.

MANHEIM, K. Liberdade, poder e planificação democrática. São Paulo: Mestre Jou, 1976.

MENDONÇA, S. R. Estado e economia no Brasil: opções de desenvolvimento. 3. ed. Rio de Janeiro: Graal, 1999.
MÜLLER, H. D. C. M. Hélio Jaguaribe, pensamento político em tempos isebianos: populismo, desenvolvimento nacional e nacionalismo (1952-1958) / Hugo Dante Cyro Macedo Müller. - 2019. 113f.

ORTEGA Y GASSET, José. Historia como sistema. S.d. Disponível em:

https://bit.ly/2XIYeYh. Acesso em: 17 Nov. 2020.

SANTOS, W. G. Raízes da Imaginação Política Brasileira. Revista Dados, n. 7. Rio de Janeiro, IUPERJ, 1970.

SODRÉ, N. W. A verdade sobre o ISEB. Rio de Janeiro: Avenir, 1978.

SCHUMPETER, J. Capitalismo, socialismo e democracia. Rio de Janeiro: Fundo de Cultura, 1961 .

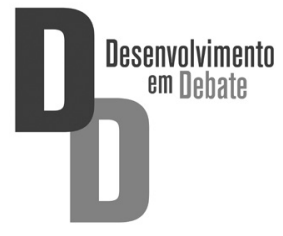





\title{
Hélio Jaguaribe, pensamento sócio-político brasileiro e desenvolvimento: entre textos, contextos e intelectuais ${ }^{1}$
}

\author{
Hélio Jaguaribe, Brazilian Sociopolitical \\ Thinking and Development: between texts, \\ contexts and intellectuals
}

\author{
Alessandro Leme*
}

\begin{abstract}
Resumo
Neste artigo vamos dar ênfase a obra de Hélio Jaguaribe a partir de um triplo movimento que envolve uma breve caracterização biográfica do autor, um segundo, evidenciando a influência do autor para o pensamento sócio-político brasileiro por meio de como a obra do autor foi mobilizada como objeto de investigação e, em terceiro, problematizar importância e tratamento que o autor realizou em prol de uma compreensão dos problemas acerca do Estado e do desenvolvimento econômico brasileiro.
\end{abstract}

Palavras-chave: Desenvolvimento; Pensamento sócio-político brasileiro; Hélio Jaguaribe.

\begin{abstract}
In this article we are going to emphasize the work of Hélio Jaguaribe from a triple movement that involves a brief biographical characterization of the author, a second, showing the influence of the author for Brazilian socio-political thought through how the author's work was mobilized as an object of investigation and, thirdly, to question the importance and treatment that the author carried out in favor of an understanding of the problems about the State and the Brazilian economic development.
\end{abstract}

Keywords: Development; sociopolitical thinking Brazil; Hélio Jaguaribe. 


\section{INTRODUÇÃO}

Os anos 20 do século XX é uma daquelas décadas que ficaram marcadas na história em função dos conjuntos de transformações sócio-políticas, econômicas e culturais ocorridas globalmente, principalmente quando pensamos o mundo ocidental e, consequentemente as influências e desdobramentos destes acontecimentos na América Latina e no Brasil em particular.

Neste contexto global e nacional, neste caleidoscópio que foi a década de 20 do século XX que nasceram três grandes pensadores brasileiros (Florestan Fernandes, Celso Furtado e Hélio Jaguaribe) que influenciaram a forma pela qual interpretamos o Brasil, principalmente a partir da segunda metade do século com os processos de industrialização crescentes no país.

Ainda que não vamos realizar um estudo comparado entre os autores, a confluência de temas e ideias entre os mesmos, de um lado e, o centenário de Fernandes e Furtado em 2020, são aspectos relevantes e merecem o registro neste artigo.

O sociólogo Florestan Fernandes que nasceu em 22 de julho de 1920 em São Paulo emorreu em 10 de agosto de 1995 em São Paulo aos 75 anos e que em 2020 marca o seu centenário. Sobre Florestan já há uma vasta produção bibliográfica, mas dois aspectos acreditamos ser relevantes para apontarmos, primeiro que Florestan é lido e reconhecido pela fortuna crítica como autor que produziu livros e obras clássicas em diferentes áreas das ciências sociais, citamos o livro "A função social da guerra na sociedade Tupinambá ", o livro "A integração do negro na sociedade de classes, vol.1 e 2"e o livro "A Revolução burguesa no Brasil: ensaio de interpretação sociológica”, este último tendo a publicação de sua 6a em 2020 (pela Editora Contracorrente) como parte das comemorações ao centenário do autor e livro inaugural da Coleção sobre Florestan Fernandes coordenada na editora por Bernardo Ricúpero. O livro ainda conta com prefácio de André Botelho e Antônio Brasil Jr. E posfácio de Gabriel Cohn. Em segundo, destacamos a ideia de sociologia e sociólogo engajado, onde o rigor científico e sociológico se articula com as consequências do fazer sociologia na sua reflexão e possibilidade de mudança social.

O economista e cientista social Celso Furtado que nasceu em 26 de julho de 1920 na Paraíba e morreu em 20 de novembro de 2004 no Rio de Janeiro aos 84 anos e 2020 também marca o seu centenário. Furtado, tal como Florestan, também possui uma obra relevante para as ciências sociais e para as interpretaçôes do Brasil, assim como também já há uma vasta produção bibliográfica sobre o autor e sua obra. Livros como "Formação Econômica do Brasil", "Desenvolvimento e subdesenvolvimento", "Subdesenvolvimento e estagnação na América Latina" e o "Mito do desenvolvimento econômico" 
entre outros, marcaram e influenciaram toda uma geração de intelectuais brasileiros e latino-americanos na segunda metade do século XX. Desde o início do século XXI, Rosa Freire d'Aguiar tem organizado a Coleção Celso Furtado com a nova edição de seus livros, assim como a publicação de material inédito, seja sobre a obra ou sobre elementos biográficos do autor.

E o cientista político Hélio Jaguaribe que nasceu em 23 de abril de 1923 no Rio de Janeiro e morreu em 9 de setembro de 2018 aos 95 anos. Embora Celso Furtado e Hélio Jaguaribe tenham feito formação em direito, fazem parte do rol de autores que nesta época, após cursar direito, enveredavam para outras áreas do saber no campo das chamadas ciências sociais em sentido mais geral. Daí o reconhecimento do Furtado na economia e do Jaguaribe na Ciência Política.

Neste artigo vamos dar ênfase a obra de Hélio Jaguaribe. O tratamento dado ao texto se insere numa aproximação de duas áreas do conhecimento na sociologia, a saber: a sociologia do desenvolvimento e o pensamento social. Neste sentido, a partir da obra de Hélio Jaguaribe nossa interpretação acaba por valorizar o texto e o contexto do autor, assim como suas intencionalidades e as derivaçóes interpretativas na maneira como o autor e sua obra foi e são mobilizadas na atualidade.

Para tal, o artigo será organizado com esta breve introdução, seguidas de três partes, asaber: uma breve caracterização biográfica do autor (nesta parte utilizamos além da bibliografia disponível, o acervo do Centro de Pesquisa e Documentação de História Contemporânea do Brasil - CPDOC); uma segunda, evidenciando a influência do autor para o pensamento sócio-político brasileiro por meio do como a obra do autor é mobilizada e, em terceiro, vamos problematizar, ainda que modestamente, a importância da chave política para a compreensão dos problemas acerca do Estado e do desenvolvimento econômico brasileiro.

\section{HÉLIO JAGUARIBE: FRAGMENTOS BIOGRÁFICOS E DE TRA- JETÓRIA}

Hélio Jaguaribe de Mattos, ou Hélio Jaguaribe como conhecido nos meios intelectuais e acadêmicos, foi um importante cientista social brasileiro, formado em Direito pela Pontifícia Universidade Católica do Rio de Janeiro em 1946. Todavia, sua obra apresentou contribuição relevante por meio da sua produção intelectual no campo da ciência política em debate com a sociologia, a economia e a história.

Em 1949, três anos após sua formatura, se torna responsável pelo suplemento cultural do Jornal do Comércio no Rio de Janeiro. Sua passagem pelo 
jornal vai ser fundamental para suas empreitadas futuras no que concerne a investigações e interpretações sobre e sociedade brasileira.

Funda em 1952, juntamente com um grupo de cientistas sociais de diferentes abordagens teórico-metodológicas o "Instituto Brasileiro de Economia, Sociologia e Política - IBESP”. O Instituto visava reformular e produzir uma nova interpretação sobre a sociedade brasileira nos seus múltiplos aspectos (sociais, políticos, econômicos e culturais). Durante este período, Hélio Jaguaribe foi secretário-geral e diretor da revista "Caderno de Nosso Tempo", periódico que apresentou forte relevância para o debate sobre o Brasil e a América Latina.

Em 1956, depois de uma curta, porém proveitosa e relevante experiência no IBESP, Hélio Jaguaribe contribui expressivamente para a criação do Instituto Superior de Estudos Brasileiros - ISEB, vinculado ao Ministério da Educação e Cultura à época. Vamos apresentar um pouco mais do debate envolvendo o Hélio Jaguaribe e o ISEB na terceira parte deste artigo.

Como muitos intelectuais brasileiros, Hélio Jaguaribe foi um crítico do golpe civil militar de 1964, o que o levou a sair do Brasil e ir para os Estados Unidos, regressando somente em 1969. No período em que esteve nos Estados Unidos, lecionou na Universidade de Harvard entre os anos de 1964 a 1966, na Universidade de Stanford entre os anos de 1966 a 1967 e, no Massachusetts Institute of Tecnology - MIT, entre os anos de 1968 a 1969.

No retorno ao Brasil em 1969, Hélio Jaguaribe passa a integrar o corpo docente e administrativo das Faculdades Integradas Cândido Mendes, sendo diretor de Assuntos Internacionais. A partir de 1979, com a criação do Instituto de Estudos Políticos e Sociais (Iepes) é designado decano e, permanecendo nesta função até 2003.

Em 1992, tem uma breve passagem pelo governo federal, assumindo entre abril e setembro a Secretaria de Governo de Ciência e Tecnologia, posteriormente alavancada ao status de Ministério.

Após esta passagem pelas instâncias governamentais, retorna a suas atividades exclusivamente acadêmicas, coordenando um projeto de pesquisa numa parceria interinstitucional entre o Iepes, a Universidade de São Paulo - USP e a Universidade de Buenos Aires - UBA. O projeto intitulado "A Critical study of history" visava revisitar e produzir novas análises acerca da história universal.

Foi honrado várias vezes pelo grau de Doutor Honoris Causa no Brasil e no exterior, destacamos os proferidos pela Universidade de Jahannes Gutenber, de Mainz, Alemanha em 1983, da Universidade Federal da Paraíba em 1992 e da Universidade de Buenos Aires em 2001. 
É eleito em 3 de março de 2005, a Cadeira n. 11 da Academia Brasileira de Letras, sucedendo Celso Furtado. Cadeira está que já foi ocupada por Darcy Ribeiro, Celso Furtado e atualmente é ocupada por Ignácio de Loyola Brandão. Um fato interessante é que a Cadeira n. 11 foi ocupada de outubro de 1992 a setembro de 2018 por autores oriundos das chamadas ciências sociais, mais especificamente, por um antropólogo, um economista e um cientista político conforme quadro 1 .

Quadro 1 - Cadeira N.11 da Academia Brasileira de Letras - Autores das Ciências Sociais

\begin{tabular}{|l|l|l|l|l|l|}
\hline Nome & $\begin{array}{l}\text { Data } \\
\text { Eleição }\end{array}$ & $\begin{array}{l}\text { Data } \\
\text { Posse }\end{array}$ & Quem Recebeu & Falecimento & $\begin{array}{l}\text { Área de } \\
\text { Conhecimento }\end{array}$ \\
\hline Darcy Ribeiro & $08 / 10 / 1992$ & $15 / 04 / 1993$ & $\begin{array}{l}\text { Candido } \\
\text { Mendes de Almeida }\end{array}$ & $17 / 02 / 1997$ & Antropologia \\
\hline Celso Furtado & $09 / 08 / 1997$ & $31 / 10 / 1997$ & Eduardo Portella & $20 / 11 / 2004$ & Economia \\
\hline Hélio Jaguaribe & $03 / 03 / 2005$ & $22 / 07 / 2005$ & $\begin{array}{l}\text { Candido } \\
\text { Mendes de Almeida }\end{array}$ & $09 / 09 / 2018$ & Ciência Política \\
\hline
\end{tabular}

Fonte: Academia Brasileira de Letras (ABL), (acesso em 10 de maio de 2020 - http://www.academia.org.br/academia/)

\section{HÉLIO JAGUARIBE: APONTAMENTOS BIBLIOMÉTRICOS}

Para apresentação quantitativa da produção acadêmica (Tese e Dissertaçôes) sobre o Hélio Jaguaribe ou sobre o ISEB (que envolve direta ou indiretamente o Hélio Jaguaribe) utilizamos o Portal de Teses da Capes (CatálogodeTeseseDissertações-http://catalogodeteses.capes.gov.br/catalogoteses/\#!/).

Existem no Brasil dois repositórios de Teses e Dissertaçóes, a saber: Portal de Teses da Capes (http://capesdw.capes.gov.br) que é o sistema online oficial e é vinculado ao Ministério da Educação (MEC) e o Banco de Teses do IBICT (http://bdtd.ibict.br/pt) que integra todas as bibliotecas digitais de teses e dissertações das universidades brasileiras que utilizam o sistema BDTD. Ainda que os dois repositórios propiciam a busca de Teses e Dissertaçóes feitas no Brasil, o Portal Capes é mais completo na catalogação das Teses e Dissertaçóes, sendo assim, optamos por fazer a busca no Portal da Capes.

Para as finalidades propostas neste artigo utilizamos, utilizamos dois conjuntos de palavras chaves para busca. Também fizemos uso de aspas nas palavras chaves a fim de afunilar as especificidades pretendidas. Numa primeira busca digitamos o nome do Autor, a saber: Hélio Jaguaribe e numa segunda rodada de buscas digitamos ISEB. Na primeira busca encontramos 13 (teses e dissertaçóes) e na segunda, encontramos 76 (teses e dissertaçóes). As apresentaçôes dos dados estão nos Quadros 2, 3, 4 e 5. 
Para evidenciarmos o como o autor é mobilizado na produção acadêmica, selecionamos duas variáveis, a primeira sendo a grande área do conhecimento (que organiza de forma mais geral os dados) e a segundo como área do conhecimento (que organiza de maneira mais específica os dados). Ambas as formas de categorização são previamente definidas pelo Portal de Teses da Capes.

Quadro 2 - Dissertação e Teses sobre Hélio Jaguaribe

\begin{tabular}{|l|c|c|c|}
\hline Grande Área de Conhecimento & Dissertações & Teses & Total \\
\hline Ciências Humanas & 09 & 03 & 12 \\
\hline Multidisciplinar & 01 & - & 01 \\
\hline Total & 10 & 03 & 13 \\
\hline
\end{tabular}

Fonte: Catálogo de Teses e Dissertações - CAPES (acesso em 07 de maio de 2020 - https://catalogodeteses.capes.gov. $\mathrm{br} /$ catalogo-teses/\#!/)

Quadro 3 - Dissertação e Teses sobre Hélio Jaguaribe - áreas de conhecimento

\begin{tabular}{|l|c|}
\hline Áreas do Conhecimento & Total \\
\hline Ciência Política & 07 \\
\hline Sociologia & 03 \\
\hline História & 01 \\
\hline Sociais e Humanidades & 01 \\
\hline Educação & 01 \\
\hline Total & 13 \\
\hline
\end{tabular}

Fonte: Catálogo de Teses e Dissertações - CAPES (acesso em 07 de maio de 2020 - https://

catalogodeteses.capes.gov.br/catalogo-teses/\#!/)

Evidencia-se que o autor é majoritariamente mobilizado na área de conhecimento das ciências humanas, onde as especialidades de Ciência Política e Sociologia correspondem por aproximadamente $80 \%$ das investigaçóes realizadas.

As Teses e dissertaçóes diretamente vinculadas a obra de Hélio Jaguaribe concentram-se majoritariamente nas investigações acerca da política e do desenvolvimento, esses dois temas em geral representam o maior interesse das autoras e autores que utilizam a obra de Jaguaribe para os problematizar acerca de algumas das questôes centrais presentes na sociedade brasileira.

Já as pesquisas sobre o ISEB em geral (Quadros 4 e 5), mostram que as especialidades da História e da Educação concentram individualmente as áreas com mais dissertaçóes e teses realizadas. Quando se soma as áreas de 
Sociologia e Ciência Política as da História e Educação, encontra-se aproximadamente $90 \%$ dos trabalhos produzidos sobre o ISEB nessas áreas de conhecimento.

É razoável afirmar que a obra de Jaguaribe em particular e as investigações a partir do ISEB em geral, representam uma importante mobilização do como o autor e o ISEB influenciaram a maneiro de como se pensa e problematiza os problemas vinculados de maneira geral a ideia de mudança social no capitalismo brasileiro. Mas também, evidencia que tal debate não ficou represado entre as décadas de 1950 a 1970, mas ainda servem de ponto de partida e reflexão sobre estratégias para o desenvolvimento, relação entre Estado e Mercado, formação educacional e reformas de base e institucionais no Brasil atual.

Quadro 4 - Dissertação e Teses sobre ISEB

\begin{tabular}{|l|c|c|c|}
\hline Grande Área de Conhecimento & Dissertações & Teses & Total \\
\hline Ciências Humanas & 46 & 23 & 74 \\
\hline Ciências Sociais Aplicadas & 02 & 01 & 03 \\
\hline Multidisciplinar & 02 & 01 & 03 \\
\hline Engenharia & 01 & - & 01 \\
\hline Total & $\mathbf{5 1}$ & $\mathbf{2 5}$ & $\mathbf{7 6}$ \\
\hline
\end{tabular}

Fonte: Catálogo de Teses e Dissertações - CAPES (acesso em 07 de maio de 2020 - https://catalogodeteses. capes.gov.br/catalogo-teses/\#!/)

Quadro 5- Dissertação e Teses sobre ISEB - áreas de conhecimento

\begin{tabular}{|l|c|}
\hline Áreas do Conhecimento & Total \\
\hline História & 23 \\
\hline Educação & 22 \\
\hline Sociologia & 13 \\
\hline Ciência Política & 11 \\
\hline Economia & 02 \\
\hline Sociais e Humanidades & 01 \\
\hline Administração & 01 \\
\hline Ciências Ambientais & 01 \\
\hline Engenharia de Produção & 01 \\
\hline Interdisciplinar & 01 \\
\hline Total & 76 \\
\hline
\end{tabular}

Fonte: Catálogo de Teses e Dissertações - CAPES (acesso em 07 de maio de 2020 - https:// catalogodeteses.capes.gov.br/catalogo-teses/\#!/) 
No site do Youtube (www.youtube.com.br) é possível encontrar algumas dezenas de vídeos envolvendo o Hélio Jaguaribe. Apenas para fins de ilustração, podemos dividir esses vídeos em 3 grandes subtemas. Primeiro, os vídeos de entrevistas e/ou fragmentos de entrevistas feitos com Hélio Jaguaribe ao longo de sua vida. Alguns dos temas mais explorados nesses vídeos são o do desenvolvimento e da política brasileira. Um segundo conjunto de vídeos se referem a seminários, congressos e comentários sobre a obra de Hélio Jaguaribe. Já num terceiro conjunto de vídeos citamos os de homenagem, principalmente após a sua morte. Ainda há o Documentário "Tudo é irrelevante: Hélio Jaguaribe", dirigido por Izabel Jaguaribe e Ernesto Baldan no ano de 2017, com 81 minutos de duração.

Há ainda duas outras formas de divulgação e mobilização do autor na produção acadêmica. A produção de artigos sobre o autor, cuja forma de acesso se daria pela busca de artigos nas bases de dados e periódicos nacionais e internacionais e sites especializados, tais como Scielo (https://scielo.org), Google Acadêmico (https://scholar.google.com.br/scholar?q=), a plataforma CAFe, vinculada ao Portal de periódicos Capes (http://www.periodicos. capes.gov.br/), entre outras.

O segundo, e de muita relevância para as investigaçóes acerca da obra de Hélio Jaguaribe é a Fundação Alexandre de Gusmão (FUNAG), instituída com base na Lei no 5.717 de 26 de outubro de 1971, é uma fundação pública vinculada ao Ministério das Relações Exteriores (http://funag.gov.br/index. $\mathrm{php} / \mathrm{pt}$-br/funag - acessado no dia 07 de maio de 2020). A FUNAG organizou a coleção sobre Hélio Jaguaribe apresentando sua obra em três conjuntos gerais de Temas, a saber: Estudos Filosóficos e Políticos; Introdução ao Desenvolvimento Social e O Nacionalismo na Atualidade Brasileira. Os três eixos temáticos de textos do autor não contemplam toda sua publicação, mas envolve grande parte dela, não somente as produzidas em artigos e capítulos de livros, mas também as conferências, aulas magnas, entre outras atividades do autor. Os textos visam dar um panorama que percorre escritos do autor entre os anos 1950 até aproximadamente 2013, ano de publicação da Coleção da FUNAG.

A FUNAG ainda publicou uma organização de artigos sobre o Hélio Jaguaribe intitulada "Visóes da obra de Hélio Jaguaribe" que foi organizada por Sérgio Eduardo Moreira Lima em 2015 e contou com homenagem a Hélio Jaguaribe de Fernando Henrique Cardoso e Luiz Inácio Lula da Silva, além de artigos de Celso Lafer, Candido Mendes, Aldo Ferrer, Samuel Pinheiros Guimarães e João Paulo de Almeida e de transcrição de agradecimentos do próprio Hélio Jaguaribe. 
Como evidenciado, além da própria obra de Hélio Jaguaribe que contempla mais de 40 publicações editadas em português, inglês e espanhol (FUNTAG, 2015). Ainda há vasto material bibliográfico e audiovisual disponível para análise e investigação sobre as proposições, visões, ensaios e reflexões do autor sobre o Brasil, a política e o desenvolvimento como chaves interpretativas.

Por fim, a revista eletrônica Insight Inteligência, edição 75 de outubro a dezembro de 2016 publicou um caderno especial sobre Hélio Jaguaribe intitulado: "Especial: o Brasil superior de Hélio Jaguaribe" e contou com os seguintes artigos: "Jaguaribe em construção: uma leitura da política brasileira em dois tempos" de Angélica Lovatto, "Cadernos para todos os tempos: a encruzilhada entre o atraso e o progresso" de Cristina Buarque de Holanda e um texto do próprio Hélio Jaguaribe intitulado "Usina de altos estudos: liçôes sem prazo de validade".

\section{CONTEXTOS E IMPLICAÇÕES: REFLEXÕES ACERCA DO DESEN- VOLVIMENTO ENTRE AS DÉCADAS 1930 A 1970}

O período histórico entre as décadas de 1930 a 1970 marcaram um conjunto de transformações econômicas, políticas, sociais e culturais em esfera mundial $^{2}$. Alguns acontecimentos, tais como o fim da Segunda Guerra Mundial, os acordos de Bretton Woods, o Plano Marshall e posteriormente, na década de 1960 a Aliança para o Progresso expressam bem o quanto este período caracteriza um conjunto de mudanças em torno da temática do desenvolvimento. Seja com políticas e acordos internacionais para criação de regras e padróes para a dinâmica econômica internacional (envolvendo o Estado-nação e o comercio internacional), seja para a reconstrução europeia do pós-guerra ou pela disponibilidade de crédito via cooperação para intensificação do crescimento econômico (industrialização e desenvolvimento) dos países latino-americanos.

No plano das políticas e orientaçôes econômicas oriundas das recém-criadas agências multilaterais (ONU, BIRD, FMI), como das condutas e práticas dos Estados nacionais, a questão do desenvolvimento econômico se torna central. Nos países desenvolvidos como forma de reconstrução econômica de alguns países impactados drasticamente pela segunda guerra mundial e, para outros, como forma de avançar no desenvolvimento e crescimento econômico sem correr os riscos de replicar as crises capitalistas das décadas de 1920/30 (Grande Depressão iniciada em 1929 e arrastada pela década de 1930). Por outro lado, os países latino-americanos adentram na agenda para 
impulsioná-los em rumo do propalado desenvolvimento e crescimento econômico via estratégia industrial.

Muitos foram os esforços realizados entre as décadas de 1930 e 1970 em compreender e explicar o capitalismo e as transformações econômicas, políticas, sociais e culturais pelas quais os diferentes países do mundo (ocidental e oriental, os do Norte e do Sul, os desenvolvidos e os subdesenvolvidos ${ }^{3}$ ) estavam passando. A questão do capitalismo neste sentido estaria vinculada a um determinado padrão de industrialização, a um tipo particular de organização burocrática do Estado e um conjunto de transformações sócio-políticas, culturais e econômicas vinculadas à ideia da mudança social, principalmente no que se refere às mudanças, ou em andamento ou em perspectiva, nos países subdesenvolvidos neste período (industrialização, modernização do rural, integração de indivíduos e classes sociais ao consumo, reforma agrária e mobilidade social, por exemplo).

Autores da história econômica, da sociologia, da ciência política e áreas correlatas das humanidades elaboraram grandes esforços analíticos e históricos no interesse explicativo einterpretativo acerca do desenvolvimento, do crescimento econômico, da industrialização e das formas de superação do atraso econômico pelos países que se encontravam em condições de baixo crescimento econômico. Cada vez ficava mais difícil justificar o desenvolvimento pela divisão internacional do trabalho, ou seja, que no comércio internacional a lógica das vantagens comparativas naturalmente levaria a todas as nações se beneficiarem das transformações tecnológicas e circulação de mercadorias em esfera global.

Com o intuito de problematizar esta questão, Agarwala e Singh organizaram uma coletânea em $1958^{4}$ (A economia do subdesenvolvimento) contendo inúmeros autores de diferentes matrizes teóricas e metodológicas que durante a década 1950 (exceção ao texto de Rosenstein-Rodan de 1943) acabaram por redefinir o campo de investigação da economia do desenvolvimento. O Livro foi organizado em seis partes e visava contemplar os principais fatores que permeavam o debate nos anos 1950.

Já o historiador econômico russo Alexander Gerschenkron, organizou um conjunto de reflexóes, principalmente a partir das discussóes do seu principal texto ( $\mathrm{O}$ atraso econômico em perspectiva histórica) acerca do desenvolvimento das economias e suas respectivas diferenças e desigualdades, principalmente por aferir que o desenvolvimento dos países retardatários seguiria características próprias e específicas nos seus processos de industrialização. A inovação analítica e metodológica do autor resultaria na superação de dois dos principais arcabouços teórico-metodológicos na história econômica durante a década de 1950 . O autor propóe a superação, ainda que a partir do 
diálogo crítico com a teoria marxista e a rostowiana, ou seja, refuta a centralidade explicativa da luta de classes na dinâmica da história no marxismo e, ao mesmo tempo, não aceita o etapismo universal e com passos comuns da abordagem de Rostow. $\mathrm{O}$ atraso econômico neste sentido seria tratado de forma comparativa e portador de uma dialética onde o atraso relativo referenciava simultaneamente problemas e oportunidades. Por outro lado, a industrialização retardatária seria um processo descontínuo e com forte necessidade de participação do Estado-Nação neste processo. O livro recém-publicado no Brasil "O atraso econômico em perspectiva histórica e outros ensaios" evidencia o conjunto de suas discussóes em 12 artigos que compóem o livro

Simultaneamente ao debate na Europa e nos Estados Unidos dos pós anos 1940, há um conjunto de reflexões produzidas no Sul, entre elas, as reflexões Latino-Americanas, do leste asiático e da África. Dado este protagonismo de autores vinculados às naçôes periféricas, por um lado e o contesto histórico-econômico, político, social e cultural vivenciado em esfera global no pós guerra, pode-se afirmar que a temática do desenvolvimento e do subdesenvolvimento assume papel de destaque tanto nas produções intelectuais de diferentes matrizes teórico-metodológicas, como também no planejamento e programas de políticas públicas e investimentos infra estruturais em prol do chamado desenvolvimento dos países em condição (e/ou situaçôes concretas) de subdesenvolvimento. 
Neste sentido, muitos autores passaram a elaborar uma explicação e/ou interpretação das respectivas condições materiais de desenvolvimento das economias capitalistas nos diferentes e desiguais Estados Nacionais (epistemologicamente vamos classificar para fins de análise a partir da nomenclatura Norte e Sul, no intuito de indicar que a posição geográfica e territorial também expressa condiçốes materiais distintas e hierarquizadas, marcando não somente uma dominação econômica, como também uma ideologia de dominação social, política e cultural). Furtado (1978) no livro "Criatividade e dependência na civilização industrial” dedica um capítulo a esta reflexão afirmando que no campo das ideias, mas também da política e práticas sociais (econômicas e culturais) a história do capitalismo a partir da revolução industrial marcaria um crescente processo de mudanças de ideologias, porém, não dos seus abandonos. Ao passo que o final do século XIX e começo do século $\mathrm{XX}$ a ideologia dominante seria a do progresso (realização do individuo iluminista e generalização das riquezas entre as naçóes), a partir da segunda metade do século XX, a ideologia que assume forma hegemônica seria a do desenvolvimento.

Sunkel e Paz (1970) ao analisarem sobre os conceitos de desenvolvimento e subdesenvolvimento, principalmente sobre as influências externas na América Latina e como o pensamento latino americano significou e explicou a sua própria condição na divisão internacional do trabalho acabou por valorizarem na reflexão três conceitos (também presentes nos constructos cepalinos), a saber: sistema, estrutura e processo. Somente a partir de uma análise que valorizasse os três conceitos que se alcançaria uma interpretação condizente com as díspares realidades com que os países desenvolvidos e os subdesenvolvidos (entre eles, os latino americanos) possuíam. Peña (1971) similarmente ao problematizar a condição mexicano no período, acaba por vincular que a relação de dependência externa na correlação de produção e reprodução simultânea do desenvolvimento e do subdesenvolvimento em esfera global acaba por aprofundar os fatores estruturais do subdesenvolvimento, ou seja, as ideias de sistema, estrutura e processo também se encontram na análise, ainda que não cunhadas textualmente na obra do autor.

Porém, não é exclusividade do campo das ciências econômicas o tratamento e análise acerca da temática do desenvolvimento, as ciências sociais e humanidades em geral e, a sociologia, ciência política e história em particular, vão apresentar uma esforço analítico fundamental para a explicação, compreensão e interpretação sobre o desenvolvimento e subdesenvolvimento, sobre a dinâmica particular do chamado por alguns de "Terceiro Mundo", sobre a questão da mudança social e da modernização, entre outras formas de tratamento reflexivo e crítico sobre a temática em voga. 
Alguns autores ao distinguirem crescimento e desenvolvimento, acabaram por criticar a ideia de que exista um processo universal e geral, ou seja, as dinâmicas endógenas são fundamentais para entender as trajetórias percorridas por cada país. Neste sentido, como salienta Perroux (1961), são as mudanças das estruturas mentais e dos hábitos (costumes etradiçôes) sociais, vinculados as transformaçóes institucionais (política) é que garante a longo prazo a sustentação do desenvolvimento e, consequentemente, o avanço e crescimento do produto global, ou seja, as práticas dentro do escopo acima propiciam os avanços em escala global e esses por sua vez, enquanto totalidades sociais garantem os avanços particulares.

Já outros autores, tais como: Hagen (1969), Costa Pinto (1963), Lewis (1960), vão focar a análise na ideia de mudança social, seja pela passagem de sociedades tradicionais para sociedade industriais, marcadas por uma mudança tecnológica expressiva ou pela necessidade de mudança no interior de sociedades e Estados altamente desiguais, rurais e com baixo crescimento econômico e alta dependência externa. Por sua vez, Touraine (1989 e 2005), ao valorizar os atores e as instituiçóes na análise do desenvolvimento, evidencia a relevância do problema do processo social (de forte articulação endógena também). Blumer (1939), Merton (1958) e Casanova (1967) são outros autores, que com diferentes análises, enfocam a importância da dinâmica dos movimentos sociais e/ou grupos de referencias como fatores fundamentais para a mudança.

Por outro lado, as discussóes sobre o desenvolvimento no século $\mathrm{XX}$ adquiriram duas perspectivas não excludentes entre si em termos gerais, poderíamos até chamar de construção de novos paradigmas ou mesmo de produção de duas epistemologias, a saber: uma primeira voltada para o entendimento e explicação do capitalismo, neste sentido, não haveria desenvolvimento, subdesenvolvimento, dependência, industrialização, modernização e mudança social senão características de produção e reprodução do capitalismo (enquanto totalidade e como particularidade concreta). A outra, vinculada as diferentes abordagens teórico-metodológicas que surgem como portadoras da interpretaçốes e explicaçốes do mundo, e do capitalismo e suas diferentes condições de desenvolvimento esubdesenvolvimento em particular, aqui apontamos a marxista, a economia clássica e neoclássica, a weberiana, a funcionalista, a estrutural-funcional, assim como a cepalina, as dualistas, as da dependência (weberiana e marxiana), entre outras.

Muitos outros autores, de diferentes matrizes teóricas vão voltar seus esforços para o entendimento do capitalismo e nele a questão do desenvolvimento no processo histórico é variável central. Aqui citamos Nurkse (1957); Myrdal (1957) Lewis (1956); Boyer (2004), mas também, Furtado 
(1978, 2008 e 2009); Bielschowsky (2000); Rodríguez (2009) entre outros. No âmbito latino-americano em particular, citamos Pereira (1977), Jaguaribe (1969), assim como os livros organizados e compilados sobre a temática, tais como "La dominación de América Latina" compilado por José Matos Mar em 1968 e contou com capítulos de Jaguaribe, Furtado, Faletto, Di Tella, Espartaco, Sunkel e Cardoso. O livro “O Estado na América Latina”organizado por Paulo Sérgio Pinheiro e com capítulos de O’Donnel, Rivas e Cardoso, o Livro "Sociologia do Desenvolvimento II, organizado por José Carlos Garcia Durand e Lia Pinheiro Machado e com capítulos de Blumer, Casanova, Lerner, Frank, Machado e Soares, entre outros livros e compilações que articulavam os principais intelectuais que produziram reflexões sobre o tema do desenvolvimento, subdesenvolvimento e da dependência na América Latina e, no Brasil, em particular.

Ao passo que essas reflexões e análises marcaram uma inflexão importante entre os anos 1930 a 1970, há um retorno do debate, ainda que com contextos e processos globais distintos (globalização e revolução tecnológica, por exemplo) no final do século XX e início do século XXI. Tal retorno não é apenas metodológico ou teórico, é também material, uma vez que parte dos problemas econômicos e sociais (pobreza e desigualdades, por exemplo) ainda permanecem como obstáculos a serem superados por parte expressiva de países no mundo, entre eles os Latino Americanos (mesmo os que passaram por um alto processo de industrialização).

Este movimento de reordenamento material, econômico, político, social e cultural também contou com um conjunto de reflexôes intelectuais e técnicas em torno das escolhas e estratégias necessárias à realização bem-sucedida de colocar os países subdesenvolvidos (ou atrasados) do capitalismo pós Segunda Guerra Mundial em rumo da prosperidade, do desenvolvimento econômico e social. O crescimento econômico, o aumento do bem-estar social e desenvolvimento humano, a modernização e a eliminação da dependência são algumas das concepções e dimensões contidas nos debates entre os anos 1930 e 1970 em esfera global, com um crescente protagonismo destas discussões na América Latina, seja em órgãos ou instituiçóes multilaterais, em institutos e centros de investigação criados ou nas universidades.

Neste sentido, o debate que esteve presente entre os anos de 1930 a 1970 marcaram significativamente os problemas que a sociedade brasileira e o capitalismo no Brasil estavam experimentando. Quando mobilizamos a obra de Jaguaribe fica evidente que o aporte do autor visa compreender os entraves e as potencialidades, assim como quais estratégias poderiam ser adotadas para a superação dos constrangimentos econômicos, sociais e políticos no Brasil. 
É neste contexto complexo e de circulação de intelectuais latino-americanos e brasilianistas que Hélio Jaguaribe se encontra, interage e se integra por continuidades e descontinuidades presentes em suas reflexões, em sua obra.

\section{HÉLIO JAGUARIBE E O ISEB: BREVES APONTAMENTOS}

Hélio Jaguaribe a partir do diálogo com a ciência política e sociologia alemã, principalmente a de influência weberiana, vai analisar o problema do desenvolvimento como uma questão eminentemente política, logo, localizada preferencialmente no âmbito do Estado-nação, onde a condução racional de estratégias para o desenvolvimento via planejamento estatal era central em sua análise. Fica evidenciado na obra do autor que sua interpretação valoriza as estratégias vinculadas aos tipos de açôes sociais realizadas, mas também reforça a importância das instituiçóes neste processo.

Durante a década de 1950, Jaguaribe foi fundamental para a criação do Instituto Superior de Estudos Brasileiros - ISEB. A partir de 1949, Jaguaribe a frente do Jornal doCommercio/Rio de Janeiro onde apresentava algumas ideias e reflexóes sobre o Brasil, seus problemas e crises a serem superadas, sejam nos aspectos econômicos, políticos ou sociais.

No ano de 1952 vários intelectuais das ciências sociais brasileira presentes no eixo Rio de Janeiro e São Paulo começam a se reunir de forma sistemática no Parque Nacional de Itatiaia para discutir os problemas do Brasil. O primeiro nome do grupo acaba sendo Grupo Itatiaia. O local do encontro, das reunióes do grupo foi escolhido estrategicamente por estar no meio entre as cidades do Rio de Janeiro e de São Paulo, cidades que contemplavam os intelectuais vinculados ao grupo.

Os intelectuais do Rio de Janeiro eram: Hélio Jaguaribe, Candido Mendes de Almeida, Alberto Guerreiro Ramos, Oscar Lourenço Fernandes, Ignácio Rangel, José Ribeiro de Lira, Israel Klabin, Cid Carvalho, Fábio Breves, Ottolmy da Costa Strauch, Heitor Lima Rocha e Rômulo Almeida, entre outros.

Os intelectuais de São Paulo eram: Vicente Ferreira da Silva, Ângelo Simões de Arruda, Almeida Salles, Paulo Edmur de Souza Queiroz, José Luiz de Almeida Nogueira Porto, Miguel Reale e Luigi Bagolin, entre outros.

A composição do Grupo Itatiaia caracterizava-se por diferentes orientaçôes Ideológicas e Políticas, ou seja, seus membros não tinham unidade teórica, pelo contrário, compunham-se de intelectuais das mais diversas filiaçóes teóricas, weberiano, marxistas, culturalistas, entre outras. Todavia, atuavam em conjunto em função do problema da necessidade de aceleração do processo de Desenvolvimento Econômico Brasileiro, ou seja, o tema, ou 
questão do Desenvolvimento acabava por unificar o grupo (ao menos por um período). Era pretensão do Grupo Itatiaia o assessoramento governamental via elaboração de projetos e propostas que visassem a superação do atraso econômico brasileiro.

Para estruturar as atividades do Grupo Itatiaia, criou-se um Instituto Brasileiro de Economia, Sociologia e Política - IBESP, financiado com recursos provenientes de Hélio Jaguaribe em 1952. O IBESP passa a publicar a Revista Cadernos do Nosso Tempo para veicular as ideias do grupo. Em 1955 o IBESP se transforma em ISEB, vinculado ao Ministério da Educação e da Cultura, embora com dotação orçamentária muito baixa. O marco fundador foi às conferências reunidas sob o título de "Introdução aos problemas brasileiros"

O ISEB era organizado em cinco departamentos:

a) Ciência Política: Hélio Jaguaribe

b) Economia: Ewaldo Correia Lima

c) Filosofia: Álvaro Vieira Pinto

d) História: Candido Mendes

e) Sociologia: Guerreiro Ramos

No ano de 1956 o ISEB começa a ofertar cursos regulares no MEC. Porém, o ISEB vai passar por uma crise no ano de 1958, decorrente do livro "O nacionalismo na atualidade brasileira" de Hélio Jaguaribe. O principal fator da discordância foi o debate entre Jaguaribe a Guerreiro Ramos acerca da importância do capital estrangeiro e da privatização do setor petroquímico para o desenvolvimento brasileiro - embate entre um capitalismo nacional ou capitalismo a partir do capital estrangeiro. Deste processo resultou à saída de ambos do ISEB. Pode-se resumidamente descrever o funcionamento do ISEB por períodos curtos vinculados a uma determinada forma de atuação. O período de 1959-1960 o ISEB centra-se nos cursos extraordinários e com forte influência dos setores organizados da sociedade civil - sindicalistas, estudantes e setores militares, por exemplo. No período de 1961-1964 pode ser caracterizado por maior engajamento ${ }^{5}$ social e político e também pela sua extinção. O envolvimento do ISEB na campanha pelas Reformas de Base proposta por João Goulart - 1961-1964 é aspecto central para a extinção do ISEB, que desde a formação, enfrenta dificuldades financeiras, ou seja, sempre teve um aporte financeiro muito restrito (TOLEDO, 2005).

Apesar de fases distintas, o ISEB centra-se no problema do capitalismo brasileiro, ou no desenvolvimento brasileiro via planejamento e investimento estatal, o papel do Estado na promoção capitalista/industrial brasi- 
leira é central. Também visa a reflexão intelectual com a prática das políticas governamentais.

Todavia, os debates e reflexóes sobre o ISEB no Brasil ocupou um espaço relevante da intelectualidade do país. Tal como o ISEB que era composto por intelectuais, em sua maioria não acadêmicos e de diferentes orientações teóricas, assim como também por várias correntes ideológicas. A crítica e reflexão sobre o ISEB também contou com uma diversidade muito grande de orientações teóricas, com isto as leituras do que foi o ISEB, sua importância ou mesmo suas Ideologias foram problematizadas por autores de abordagens teóricas muito distintas. Teve importância neste debate crítico Toledo, 1977, Abreu, 2005, Pereira, 2005 Bresser-Pereira, 2004, entre outros. As publicaçôes sobre o ISEB ou sobre os autores isebilianos facilmente passam de uma centena no Brasil.

Não visava-se aqui, esgotar o debate acerca da relação do ISEB com Hélio Jaguaribe, mas apenas contextualizar a trajetória do autor, no qual a criação, debate, crise e extinção do ISEB são aspectos fundamentais.

Por um lado, Hélio Jaguaribe (e sua atuação no ISEB em particular) vai centrar seus esforços analíticos e intelectuais sobre os problemas brasileiros da década de 1950, onde a questão do desenvolvimento econômico e políticos são peças chaves. Neste percurso o autor vai se apoiar muito mais na influência germânica do que francesa (dos intelectuais do passado) para suas reflexões.

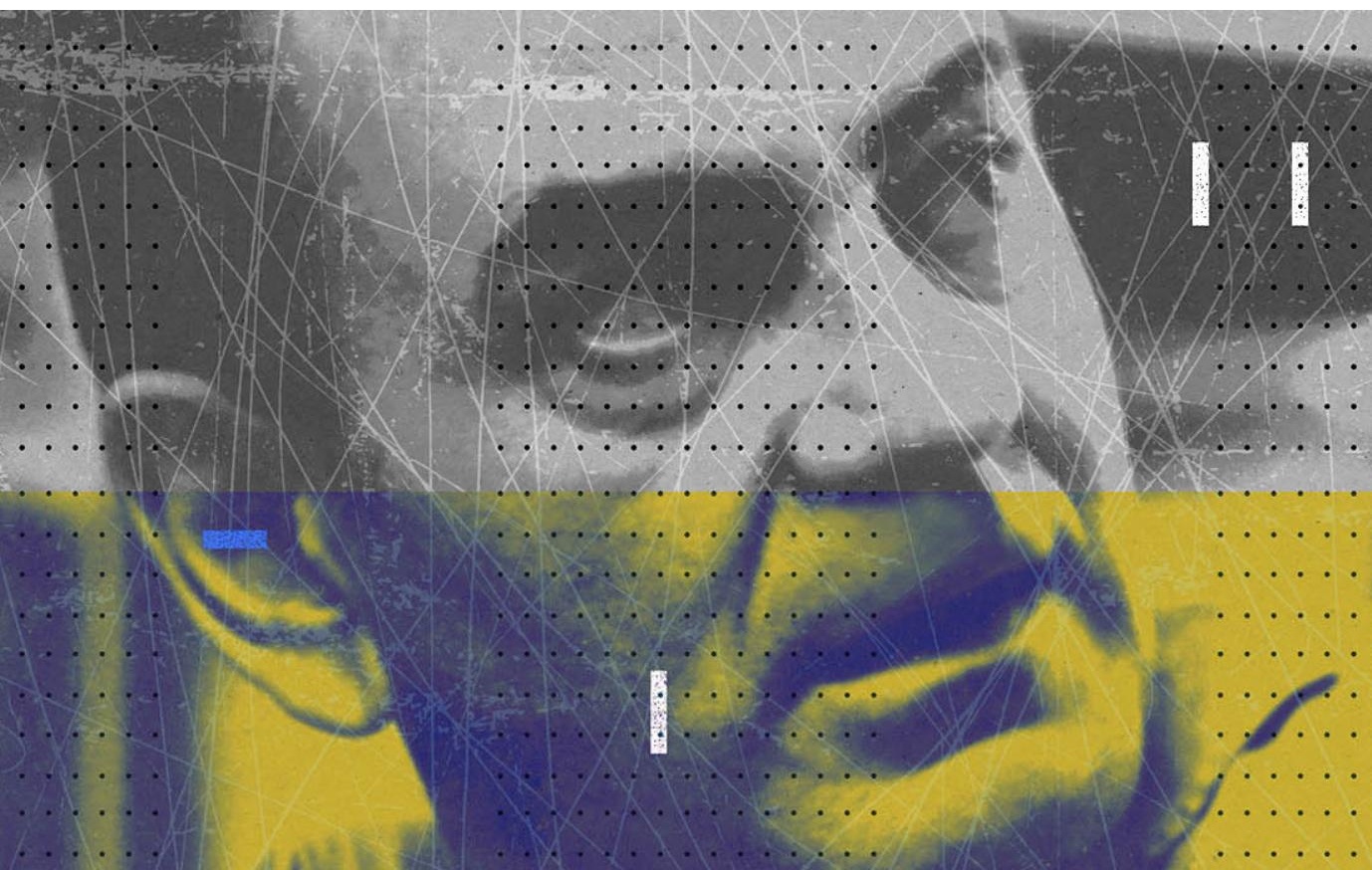




\section{HELIO JAGUARIBE E A QUESTÃO DO DESENVOLVIMENTO}

Helio Jaguaribe (1953; 1956a; 1956b; 1968) identificava uma crise das ideias no século XX a partir da observação da Europa, todavia, sua atenção maior voltou-se para o Brasil, entendido como partícipe da crise ocidental. Neste sentido, as análises do autor concernente a mudança social, principalmente as vinculadas ao crescimento das cidades e a expansão da indústria era resultado da desagregação da economia rural baseada no latifúndio. Segundo Weffort (2006), esse descompasso entre o rural e o urbano-industrial no que concernem às necessidades sociais e culturais na perspectiva de Jaguaribe reforça a importância da cultura na análise sobre os problemas do Brasil.

Jaguaribe (1954; 1956b; 1958a; 1958b;), ao apoiar sua ciência política e sociologia com a perspectiva econômica embasada em Celso Furtado, identificou que alguns fatores históricos funcionaram como condicionantes para as mudanças que começaram a ocorrer de maneira mais intensa a partir da década de 1930. Fatores como a lei de repressão ao tráfico de escravos (1850) e a lei da abolição da escravatura (1888), além das reorientações econômicas decorrentes da crise de 1929, levariam o Brasil a perseguir uma trajetória cada vez mais centrada no mercado interno, ou seja, estariam dadas as condiçóes para transferir para dentro do país a dinâmica da economia (WEFFORT, 2006).

Outros fatores também contribuiriam para o autor, ao dificultarem a importação dos produtos/mercadorias necessárias ao consumo interno no Brasil, seriam as guerras mundiais (primeira e segunda) e as crises cambiais. Neste processo de crise, a indústria passava gradativamente a substituir as importaçôes de bens de consumo e, em posteriormente, dos bens de produção.

Hélio Jaguaribe (1956b; 1968) divide a história do Brasil em 3 níveis de desenvolvimento, o primeiro e mais longo (cerca de três séculos e meio) foi a condição de colônia. O segundo, a partir de aproximadamente 1850 até meados da década de 1930 seria caracterizado pela fase semicolonial. Da década de 1930 para frente o país entraria na fase do desenvolvimento nacional, marcado pela intensificação do urbano e do industrial.

Porém, esta terceira fase de desenvolvimento nacional no Brasil também seria portadora de contradiçóes ou de incertezas, se por um lado, o passado, a história e as transformações pelas quais o país passou desde colônia foram fundamentais para o surgimento do desenvolvimento nacional, também trouxeram pontos de estrangulamentos (econômicos e sociais) capazes de bloqueá-lo ou mesmo abortá-lo. No plano político, das instituições também havia pontos de estrangulamentos, principalmente na lentidão do Estado dar respostas, ou pela permanência da chamada política de clientela, uma 
persistência do patrimonialismo num Estado que adquire padrões de racionalidade burocrática.

Para Jaguaribe haveria no Brasil um descompasso e estrangulamento entre a formação da poupança e a aplicação de investimentos com as chamadas necessidades econômicas e sociais da população em geral. No aspecto social em particular, o desenvolvimento brasileiro sofreria estrangulamentos pela permanência de privilégios de classe, sendo que esses privilégios alcançavam permeabilidade e forma na política de clientela no âmbito do Estado.

A questão do desenvolvimento brasileiro assume no autor dois níveis distintos, mas complementares, um teórico global centrado na racionalização dos processos econômicos, políticos, sociais e culturais e, outro empírico de análise dos progressos e obstáculos presentes no Brasil. Haveria uma relação quantitativa e qualitativa no desenvolvimento, onde as expressóes econômicas estariam em interdependência com as expressóes políticas, culturais e sociais em sentido mais amplo.

O fator prático ou empírico extraído daí se vincula à necessidade de pensar e implantar o planejamento estatal, associado à reforma no âmbito político (no Estado) como o principal gerador de transformaçóes sociais no país, no caso em particular, promover o tão propalado desenvolvimento brasileiro (econômico, político, social e cultural).

Ainda que o desenvolvimento possa ser entendido num sentido global para Jaguaribe, a forma interna deste processo no Brasil estaria vinculada à atuação, em situação de interdependência, das diferentes classes sociais ou fraçóes da sociedade que conseguiam imprimir suas demandas e interesses no âmbito do Estado. Mesmo considerando a necessária participação de todas as classes no processo, fica evidente que caberia papel central a burguesia industrial para a transição de uma situação de semicolonialismo para a de desenvolvimento nacional.

Partindo de um aporte weberiano, de um lado, e de uma lógica dualista estrutural (arcaico e moderno), de outro, o autor evidencia que as transformaçôes em prol do desenvolvimento decorreriam da atuação de todos os setores e classes da sociedade brasileira interligada por suas respectivas situações de classe nas diferentes dimensóes (econômica, política, social e cultural). Neste sentido o debate e/ou luta deveria se dar menos entre classes e mais no interior das classes.

As questóes acerca do desenvolvimento e do nacionalismo via planejamento estatal, ou seja, a reforma na esfera da política (Estado) como fundamental para este processo caracterizou o fundamento pelo qual Jaguaribe discordava dos nacionalistas mais radicais ao afirmar que a utilização do capital estrangeiro é central para a promoção do desenvolvimento nacional. 
O capital estrangeiro não seria uma força oposta ao nacional, mas sim apenas uma força externa. Mais uma vez este argumento reforça a dimensão global que o autor quer dar ao desenvolvimento, mesmo quando analisado na particularidade, como no caso do desenvolvimento brasileiro.

A forma e conteúdo da reforma política necessária a este processo se daria pela transição do Estado Cartorial, centrado no clientelismo e com isto, reiterador do atraso brasileiro. Já o Estado Funcional marcaria uma política ideológica voltada para o nacional, ainda que não visto em oposição ao investimento estrangeiro. A ideologia nacional tem uma força de eficácia e objetividade assumidas nas formas institucionais fundamentais ao desenvolvimento do país.

Por fim, mas não esgotando o debate sobre o autor, há íntima relação entre desenvolvimento econômico e desenvolvimento político, que assumem uma dupla condição, uma geral, enquanto desenvolvimento global e, outra particular, ou seja, como movimento inerente à realidade cultural de um determinado país. Nesta segunda parte do movimento, poderia se dizer que ao ocorrer como particularidade, ocorreria simultaneamente como realização também do global, porém com as possibilidades de progressos e estrangulamentos dados no plano interno.

Daí que no livro "Desenvolvimento Econômico e Desenvolvimento Político" há a defesa da escolha do modelo de nacional capitalismo como a trajetória a ser percorrida pelo Brasil. Do ponto de vista típico ideal, haveria duas formas de engendrar o capitalismo, uma espontânea vinculando ao desenvolvimento ao livre movimento do mercado. Outra que o autor chama de Bismarchiana ${ }^{6}$, onde a atuação do planejamento estatal é fundamental, ou seja, o desenvolvimento, inclusive o econômico, estaria em relação de interdependência com o da política. Porém, para a existência do nacional capitalismo é preciso que já se tenha em curso no país um desenvolvimento econômico com a liderança do empresariado burguês e de um Estado fortemente atuante no planejamento. Ambos os tipos expressariam tipos globais de racionalização.

Evidencia-se na obra de Jaguaribe, assim como em muitas das entrevistas que o autor deu durante a sua vida, que o debate do desenvolvimento brasileiro durante o período de existência do ISEB e as décadas seguintes (1970 e 1980) marcaram um processo onde se pensava o desenvolvimento vinculado à ideia de transformação do capitalismo no país. Esta chave, denominada em termos gerais de nacional desenvolvimentismo para o autor, marcaria a necessidade e o entendimento de que qualquer mudança da sociedade brasileira viria somente com o desenvolvimento do capitalismo no Brasil. Por sua vez, tal raciocínio contém múltiplas ideias e questôes que perpassaram como 
aspectos centrais a aliança entre o Estado e o mercado, expresso no capital (nacional e internacional). Do Estado viria o planejamento e do mercado a dinâmica econômica e como aspectos secundários estaria a necessidade de pactos de classes e de estratégias em prol do desenvolvimento articulando os múltiplos atores sociais, econômicos e políticos da sociedade brasileira.

Neste sentido, parece ter um sintonia fina, ainda que muitas vezes não declarada, entre os autores que estão produzindo entre os anos 1950 a 1970 sobre a temática do desenvolvimento brasileiro, tais como Celso Furtado, Florestan Fernandes, Fernando Henrique Cardoso, Otávio Ianni, Francisco Weffort, Guerreiro Ramos, entre outros, ainda que com diferenças entre si, viam na consolidação do capitalismo brasileiro o melhor caminho para as transformaçôes sociais que o país precisava, ou seja, na dinâmica da história em que os referidos autores pensavam, o Brasil precisaria ter atores (e/ou sujeitos) dinâmicos e fortes para poderem disputar projetos de país de maneira a ser integrativo, mesmo nos limites históricos imposto pelo capitalismo. A superação do subdesenvolvimento, a modernização do país, as mudanças estruturais, a industrialização, entre outros aspectos, estaria intimamente ligada à densidade e dinâmica que o capitalismo assumiria na sociedade brasileira em relação e correspondência com o Estado via planejamento. E desta relação de cumplicidade, porém não sem tensôes, seria gerado o tão propalado desenvolvimento do país com algum grau de correção das assimetrias sociais e econômicas entre as classes sociais e regióes brasileiras.

Por outro lado, Jaguaribe entende que a dinâmica do capitalismo brasileiro se estruturaria numa dupla dimensão, a saber: a nacional com todos os atores e implicaçôes envolvidas e a global em termos de fluxos de produção e reprodução capitalista, ambas como marcadores de racionalidade. Mais uma vez o autor e muitos dos seus contemporâneos aqui citados, dialogam em suas abordagens com o universal/global e o nacional/regional, ou seja, articulam simultaneamente ideias de totalidades e particularidades históricas para se pensar e interpretar o capitalismo brasileiro.

\section{CONSIDERAÇÕES FINAIS}

Reforçamos aqui nas consideraçôes finais a importância de Helio Jaguaribe para opensamento social e político brasileiro, a trajetória do autor e os temas de investigação escolhidos pelo mesmo o colocam em sintonia com o debate do seu tempo sobre os principais desafios da sociedade brasileira, assim como também, os possíveis caminhos a serem trilhados. Neste sentido, Jaguaribe não se contentou em ser um interprete, mas também visou construir ou indicar caminhos para a mudança, seja na sua vida intelectual ou nos seus 
múltiplos envolvimentos com instituições e agentes do Estado, tais como sua participação no ISEB e a importância deste para a implantação de um tipo particular de nacional desenvolvimentismo que acabou por influenciar o governo de Juscelino Kubitschek (1956-1960), a elaboração do projeto "Brasil 2000" para o governo de José Sarney, ou ainda, sua participação na secretaria de Ciência e Tecnologia do governo Fernando Collor de Melo.

Jaguaribe apresentou uma abordagem sociológica e política que visava interpretar o desenvolvimento, ou necessidade de desenvolvimento brasileiro (e latino-americano), ainda que por meio de influência de análises e teorias europeias, a partir da particularidade regional em que se inseria a análise, ou seja, interpretar a partir da América Latina os processos pelos quais a própria região vinha passando trouxe especificidades na obra do autor.

Jaguaribe ainda estabeleceu seu modelo interpretativo a partir da América Latina, ainda que sobre grande influência das abordagens teóricas germânicas e relaciona o problema do econômico ao problema da política, todavia, a partir do movimento da burguesia nacional e do papel planejador do Estado. No entanto, seu nacionalismo não é excludente com o capital estrangeiro, sendo este último apenas visto como de fora, porém, necessário ao desenvolvimento nacional.

Por fim, Jaguaribe se encontra ao lado dos autores que produziram interpretaçóes sobre o Brasil e que exerceram grande influência na formação de toda uma geração de cientistas sociais, principalmente quando se trata do tema do desenvolvimento e capitalismo brasileiro, mantendo até os dias atuais elementos e chaves analíticas interessantes para problematizar as condições sociais, econômicas e políticas do Brasil em particular e da América Latina em geral. Embora, a partir de 2013 as orientações de política econômica no Brasil começam a gradativamente incorporar um viés mais liberal no sentido pró mercado que se intensificaram no impeachment ${ }^{7}$ da presidente Dilma e na eleição do presidente Bolsonaro com a indicação de Paulo Guedes para ministro da economia. As crises atuais, os desencontros nas ações governamentais e os efeitos da pandemia na esfera social e econômica cada vez mais indicam a necessidade de novos pactos entre classes, atores e instituiçóes para conseguirmos superar a crise. Aqui mais uma vez, Jaguaribe nos parece interessante porque tal como nas análises do autor sobre o Brasil dos anos 1950 a 1970, por exemplo, o Brasil atual também requer de racionalidade e pactos entre atores, instituiçóes e classes, em outras palavras, a necessária articulação entre Estado e Mercado e a centralidade do planejamento na política econômica nos parece ainda ser uma questão de primeira grandeza no Brasil. 


\begin{abstract}
Notas
${ }^{1}$ Está pesquisa contou com apoio financeiro da Fundação Carlos Chagas Filho de Amparo à Pesquisa do Estado do rio de Janeiro - FAPERJ.

${ }^{2}$ No plano europeu, em particular, ainda se refere ao chamado período de ouro do capitalismo, ou os trinta anos gloriosos do capitalismo, onde a combinação de estratégia econômica de orientação keynesiana com a democracia representativa no âmbito do Estado vão caracterizar uma das experiências mais bem sucedidas de Estado de Bem Estar Social (Welfare State) que conseguiu alinhar crescimento econômico e desenvolvimento social, ou seja, crescer com equidade, distribuição de renda e estabilidade política.

${ }^{3}$ Cabe ressaltar que o conceito de subdesenvolvimento é forjado a partir da periferia do sistema capitalista e também da periferia da produção intelectual no intuito de caracterizar a condição histórica e os processos econômicos e sociais pelos quais os países Latino Americanos (principalmente), asiáticos e africanos estavam passando. Mas também não deixa de ser um conceito crítico ao estabelecer que desenvolvimento e subdesenvolvimento eram contemporâneos e não um anterior ao outro. Celso Furtado é um dos principais autores neste debate.

${ }^{4}$ Aqui utilizamos a versão publicada pela Contraponto e pelo Centro Internacional Celso Furtado em 2010

${ }^{5}$ Sobre o engajamento do ISEB na sua última fase, ver LOVATTO, 2017

${ }^{6}$ Duas outras formas são construídas pelo autor, o capitalismo de Estado e o socialismo desenvolvimentista. Esses seriam mais fáceis de implantar, porém mais difíceis de manter. Ao passo que o nacional capitalismo seria mais difícil de implantar, porém mais fácil de manter. Além do mais, ao passo que o nacional capitalismo seria democrático, o capitalismo de Estado e o socialismo desenvolvimentista seriam autoritários.

${ }^{7}$ Marcado por inúmeras controvérsias, inclusive sendo tratado por parte da literatura como um golpe em sua forma moderna, qual seja, a de ser realizado por meios dos próprios arranjos institucionais do Estado.
\end{abstract}

\section{Bibliografia}

ABREU, A. A. A ação política dos intelectuais do ISEB. In: NAVARRO, C. T. Intelectuais e política no Brasil: a experiência do ISEB. Rio de Janeiro: Editora Revan, 2005.

AGARWALA, A. N. \& SINGH, S. P. (org.). A economia do subdesenvolvimento. Rio de Janeiro: Contraponto: Centro Internacional Celso Furtado, 2010.

BIELSCHOWSKY, R. (org.). Cinquenta anos de pensamento na Cepal (vol 1 e vol 2). Rio de Janeiro: CEPAL, 2000a.

BIELSCHOWSKY, R. Pensamento econômico brasileiro: o ciclo ideológico do desenvolvimentismo. Rio de Janeiro: Contraponto, 200ob.

BOYER, R. Une théorie du capitalisme est-elle possible? Paris: Odile Jacob, 2004.

BLUMER, H. An appraisal of Thomas and Znaniecki'. s The Polish peasants in Europe and America (Critiques of research in the social sciences). Social Science Research Council: Bulletin: 44. Volume 1 de Critiques of research in the social sciences, 1939
BOTELHO, A. As viagens de Mario de Andrade à Amazônia entre raízes e rotas. Rev. Inst. Estud. Bras., São Paulo, n. 57, p. 15-50, dez., 2013

BRESSER-PEREIRA, L. C. Seis Interpretações sobre o Brasil. DADOS - Revista de Ciências Sociais, Rio de Janeiro, v. 25, n. 3، pp. 269-306, 1982

CASANOVA, P. G. Las categorías del desarrollo económico y la investigación em Ciencias Sociales. México: Instituto de Investigaciones Sociales, Universidad Nacional Autónoma de México, 1967

COSTA PINTO, L. La sociología del cambio y el cambio de la sociología. Buenos Aires: Eudeba, 1963

FERNANDES, F. Sociedade de classes e subdesenvolvimento. Rio de Janeiro, Zahar Editores, 1981

FURTADO, C. Criatividade e dependência na civilização industrial. Rio de Janeiro: Paz e Terra, 1978. 
FURTADO, C. Economia do desenvolvimento (curso ministrado na PUC-SP em 1975). Rio de Janeiro: Contraponto: Centro Internacional Celso Furtado, 2008.

FURTADO, C. Desenvolvimento e subdesenvolvimento. Rio de Janeiro: Contraponto: Centro Internacional Celso Furtado, 2009.

GERSCHENKRON, A. O atraso econômico em perspectiva histórica e outros ensaios. Rio de Janeiro: Contraponto: Centro Internacional Celso Furtado, 2015.

HAGEN, E. E. As origens do desenvolvimento. São Paulo: Editora Fórum, 1986.

IANNI, O. Estado e Planejamento Econômico no Brasil. RJ: Editora Civilização Brasileira, 1986.

IANNI, O. Tipos e mitos do pensamento brasileiro. Revista Sociologias, Porto Alegre, ano 4, n.7, janeiro-junho, 2002.

JAGUARIBE, H. A crise brasileira. Cadernos do Nosso Tempo, $\mathrm{n}^{\circ} 1$. Rio de Janeiro: IBESP, 1953.

. Situação política brasileira. Cadernos do Nosso Tempo, $\mathrm{n}^{\circ}$ 2. Rio de Janeiro: IBESP, 1954.

. Para uma política nacional de desenvolvimento. Cadernos do Nosso Tempo, $\mathrm{n}^{\circ} 5$. Rio de Janeiro: IBESP, 1956a.

O problema do desenvolvimento econômico e a burguesia nacional. São Paulo: Coleção Fórum Roberto Simonsen, 1956b.

. Condições institucionais ao desenvolvimento. Rio de Janeiro: ISEB, 1958.

. O nacionalismo na atualidade brasileira. Rio de Janeiro: ISEB, 1958b.

. Desenvolvimento econômico e desenvolvimento político. Rio de Janeiro: Paz e Terra, 1968.

"O ISEB e o desenvolvimento nacional" In: TOLEDO, C. N. Intelectuais e política no Brasil. A experiência do ISEB. Rio de Janeiro: Revan, 2005.

LAHUERTA, M. Intelectuais e resistência democrática: vida acadêmica, marxismo e política no Brasil. Cadernos AEL, v. 8, n. 14/15, 2001.
LEME, A. A. Desenvolvimento e sociologia: uma aproximação necessária. Revista Sociedade e Estado, Brasília, v. 30, n. 2, p. 495-527, ago. 2015.

LEME, A. A. \& LENK, W. Desenvolvimento e política: apontamentos em Fernando Henrique Cardoso e Hélio Jaguaribe. e-l@tina: Revista electrónica de estudios latinoamericanos, v. 13, n. 49, Buenos Aires, Oct.-Dic, 2014a.

LEME, A.A; BRASIL JR. A.S. Sociologia do Desenvolvimento e Pensamento Social no Brasil: proposta para uma agenda de pesquisa. Dossiê: pensamento social, desenvolvimento e desafios contemporâneos; dez. Crítica e Sociedade: revista de cultura política. v. 4, n. 2, 2014b

LEWIS, A. A teoria do desenvolvimento econômico. Editora: Zahar, 1960.

LEWIS, A. The theory of economic growth. The Economic Journal, v. 66, n. 264, pp. 694697, Dec. 1956

LIMA, N. T. \& BOTELHO, A. Malária como doença e perspectiva cultural nas viagens de Carlos Chagas e Mário de Andrade à Amazônia. Hist. cienc. Saúde-Manguinhos, Rio de Janeiro, v. 20, n. 3, p. 745-763, Sept. 2013.

LOVATTO, A. Pensamento Político Brasileiro no Último ISEB (1961-64). GT-31 - Teoria Política e Pensamento Político Brasileiro conflito, poder, legitimidade e Estado. 410. Encontro Anual da ANPOCS, 2017.

MARX, K. Manuscritos económico-filosóficos. São Paulo: Nova Cultural, (Coleção Os Pensadores), 1991.

MATOS MAR, José. La dominación de América Latina. Buenos Aires: Editorial Amorrortu, 1972.

MERTON, T. Ascenção para a verdade. RJ: Editora Itatiaia, 1958.

MYRDAL, K. G. O estado do futuro: o planejamento econômico nos estados de bem-estar e suas implicações internacionais. Rio de Janeiro: Zahar, 1962. 
MYRDAL, K. G. Teoria Econômica e Regiões Subdesenvolvidas. Rio de Janeiro: Editora Saga, 1957.

MYRDAL, K. G. Perspectivas de uma economia internacional. Rio de Janeiro: Editora Saga, 1967.

NURKSE, R. Problemas da Formação de Capital em Países Subdesenvolvidos (1952). Rio de Janeiro: Editora Civilização Brasileira, 1957.

NURSKE, R. Equilibrium and growth in the world economy. HABERLER, G. \& STERN, R. M. (Eds.). Harvard Economic Studies CXVIII. Cambridge (MA): Har- vard University Press, 1961.

OLIVEIRA, F. A economia brasileira: crítica à razão dualista. Rio de Janeiro. Vozes, 1988

PEÑA, F. C. Dependencia Y câmbios estructurales. México: Instituto de Investigaciones Economicas. Universidad Nacional Autonoma de Mexico, 1971.

PEREIRA, A. E. Intelectuais, política e cultura na formação do ISEB. In NAVARRO, C. T. Intelectuais e política no Brasil: a experiência do ISEB. Rio de Janeiro: Editora Revan, 2005.

PERROUX, F. Economia e sociedade. Editora: Duas Cidades, 1961.

PERROUX, F. A Economia do Século XX. Lisboa: Livraria Morais Editora. PERROUX, F. Nota Sobre o Conceito de "Pólo de Crescimento". In: PERROUX, F; FRIEDMANN, J \& TINBERGEN, J. A Planificação e os Pólos de Desenvolvimento. Porto: Edições Rés Limitada, 1967, pp. 5-26. 82 p
RODRÍGUEZ, O. O estruturalismo LatinoAmericano. Rio de Janeiro: Civilização Brasileira, 2009.

ROSTOW, W. W. The stages of economic growth. Economic History Review, ago, 1959.

ROSTOW, W. W. Etapas do desenvolvimento econômico (um manifesto não comunista). 5. ed. ampl. Rio de Janeiro: Zahar, 1974.

SUNKEL, O. \& PAZ, P. El Subdesarrollo Latinoamericano y La Teoría del Desarrollo. México: Siglo Veintiuno, 1970.

SUNKEL, O. \& PAZ, P. Um ensaio de interpretação do desenvolvimento latino-americano. Forum Editora, 1975.

TOLEDO, C. N. ISEB: Fábrica de Ideologias. São Paulo: Ática, 1982.

TOLEDO, C. N. (org). Intelectuais e política no Brasil. A experiência do ISEB. Rio de Janeiro: Revan, 2005.

TOURAINE. A. Palavra e Sangue: Política e Sociedade na América Latina. Tradução de Iraci D. Poleti. São Paulo: Editora da Universidade Estadual de Campinas, 1989

TOURAINE, A. Brasil em Desenvolvimento, v. 2. São Paulo: Civilização Brasileira, 2005

WEFFORT, F. Formação do pensamento político brasileiro: ideias e personagens. Editora Ática, 2006.

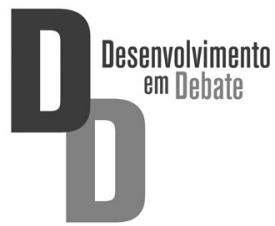




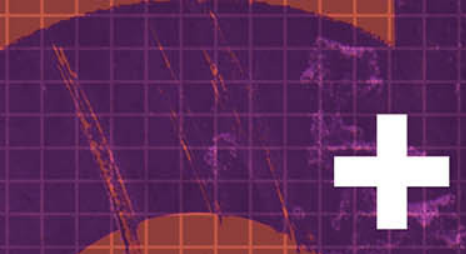




\title{
Desenvolvimento autônomo e crise estrutural do capitalismo no século XXI
}

\author{
Autonomous Development and Structural \\ Crisis of Capitalism in the $21^{\text {st }}$ Century
}

\author{
Humberto Machado Lima Junior*
}

\begin{abstract}
Resumo
Este artigo aborda como os princípios constitutivos do conceito de desenvolvimento autônomo de Hélio Jaguaribe oferecem respostas à crise estrutural do capitalismo global no século XXI. Essa crise émarcada pelo empoderamento do capital sobre o trabalho que repercute na privatização do capital e na estagnação da demanda. Diante desse processo político-econômico global, gerado pela austeridade neoliberal, o desenvolvimento autônomo aponta para políticas distributivas e de transformação produtiva das economias periféricas visando o reequilíbrio da divisão internacional do trabalho. Tal perspectiva aproxima as teses de Jaguaribe das propostas neokeynesianas para conter o avanço do neofascismo global no início do século XXI.
\end{abstract}

Palavras-chave: Desenvolvimento Autônomo Neoliberalismo - Neokeynesianismo - Capitalismo - Democracia.

\begin{abstract}
This article discusses how the constitutive principles of HélioJaguaribe's concept of autonomous development provide answers to the structural crisis of global capitalism in the 21st century. This crisis is marked by the empowerment of capital over labor that has an impact on the privatization of capital and the stagnation of demand. In the face of this global political-economic process, generated by neoliberal austerity, autonomous development points to distributive and productive transformation policies in peripheral economies aiming at rebalancing the international division of labor. This perspective brings Jaguaribe's theses closer to the neo-Keynesian proposals to contain the advance of global neo-fascism in the beginning of the $21^{\text {st }}$ century.
\end{abstract}

Keywords: Autonomous Development - Neoliberalism - Neokeynesianism - Capitalism - Democracy.

\footnotetext{
* Professor de SciencesPo-Paris - Printemps 2019. Pesquisador Visitante ITS-Rio. https://orcid.org/0000-0001-5846-0403.E-mail: humbertoplatao@bol.com.br
} 


\section{INTRODUÇÃO}

Um dos cânones da ciência política e da sociologia produzidas no Brasil, fundador e primeiro presidente do Iseb ${ }^{1}$ (principal centro difusor da ideologia nacional-desenvolvimentista), Hélio Jaguaribe deixou um legado teórico que se comunica não apenas com os anos 1950, mas, sobretudo, com o desenvolvimento global do século XXI. Em sua obra clássica $O$ Nacionalismo na Atualidade Brasileira (1958), Jaguaribe analisa como através do desenvolvimento autônomo seria possível a países periféricos regularem a entrada de capital externo de maneira a alterarem seu status na divisão internacional do trabalho. Essa mudança seria promovida pela intervenção de um Estado Keynesiano forte que suprimisse a sobre-representação na burocracia estatal dos segmentos sociais tradicionais comprometidos com a lógica exploratória dos países centrais.

A hipótese investigada nesse artigo é de que esse mecanismo de controle na administração pública local do clientelismo orientado de políticas econômicas internacionais dialoga com as respostas do Neokeynesianismo Global à crise estrutural do capitalismo no século XXI. Por meio de análise bibliográfica, esse artigo pretende mostrar como as teses sobre o desenvolvimento autônomo se inserem no debate sobre governança global no que tange a realização de acordos transnacionais que promovam políticas distributivas e de inclusão democrática para equilibrar a relação entre capital e trabalho e conter o avanço do neofascismo global (WOLF, 2019; PIKETTY, 2014; KRUGMAN, 2018).

$\mathrm{Na}$ sessão inicial abordaremos o papel do desenvolvimento autônomo para a transformação produtiva com equidade social, assim como, para o enfrentamento do cartorialimo ${ }^{2}$ exercido pelas elites tradicionais interessadas na manutenção da economia nacional em status periférico no sistemamundo. Na parte seguinte, trataremos dos efeitos da austeridade neoliberal em escala global sobre o aumento da assimetria entre centro e periferia, sobre o empoderamento do capital em relação ao trabalho, e por conseguinte, sobre a crise estrutural do capitalismo global no século XXI. Por fim, iremos analisar as contribuiçốes do Desenvolvimento Autônomo e do Neokeynesianismo Global para a crise do modelo de desenvolvimento global pósneoliberal.

Por Estado cartorial se entende, basicamente, um Estado caracterizado pelo fato de que as funções públicas, embora se apresentando como atividades orientadas para a prestação de determinados serviços à coletividade, ou seja, determinados "serviços públicos" são, na verdade, utilizadas, se não mesmo concebidas, para assegurar empregos e vantagens específicas a determinadas pessoas e grupos. O Estado cartorial é o resultado típico da política 
de clientela quando esta atinge amplas proporçôes e permeia o Estado em seu conjunto.” Acessível em: http://www.fgv.br/Cpdoc/Acervo/dicionarios/ verbete-tematico/estado-cartorial

\section{O DESENVOLVIMENTO AUTÔNOMO E A ASCENSÃO DAS ECO- NOMIAS PERIFÉRICAS NO CAPITALISMO GLOBAL}

O desenvolvimento autônomo de uma nação, segundo Hélio Jaguaribe, parte da capacidade dos seus setores progressistas, unidos em um pacto supraclassista, de modificar o modo de produção nacional, através de uma transformação tecnológica, tendo em vista o projeto histórico de seu povo. Essa transformação produtiva, à luz da tomada de consciência crítica da formação histórica da nação, requer uma reforma institucional que desvencilhe a burocracia estatal do aparelhamento reacionário por parte das elites tradicionais e permita ao Estado promover o desenvolvimento nos níveis político, econômico e ideológico (SOUZA \& SILVA, 2007). Está implícita nessa análise a relação de sustentação recíproca entre estrutura (modo produtivo) e superestrutura (ideologia e instituiçóes sociais e políticas), tal como se expressa na teoria marxista (JAGUARIBE, 2014).

Nesse quadro teórico, a subjugação epistêmica às matrizes eurocêntricas, que tornavam difusa a percepção popular sobre o processo histórico nacional, teria sido legada do período colonial para o republicano gerando uma ideologia nacional de raízes exógenas subalterna aos interesses dos países centrais do capitalismo. Essa subalternidade ideológica seria reproduzida pelas classes tradicionais vinculados ao modo de produção que mantém o país em condição periférica perante a divisão internacional do trabalho em que os países centrais apresentam um modo produtivo capital-intensivo, com concentração tecnológica, enquanto os países periféricos se voltam para a produção de commodities trabalho-intensiva (SOUZA \& SILVA, 2007).

A percepção de Jaguaribe sobre a divisão internacional do trabalho parte da sua leitura das teses elaboradas pelo economista Raúl Prebisch junto à CEPAL as quais estabeleciam um diálogo entre o keynesianismo e a teoria estruturalista. Do livro A teoria geral do emprego, do juro e da moeda Prebisch assumiu a premissa keynesiana de que a auto regulação do mercado não seria capaz de oferecer respostas aos problemas cíclicos do capitalismo no que tange ao desemprego estrutural e à distribuição e renda. A resolução desses casos precisaria da construção de um Estado forte que atuasse diretamente na economia de maneira a constante inovação tecnológica e a dinamização do mercado. Desse modo, o Estado seria capaz de controlar a 
competitividade do mercado, assim como o desemprego e a distribuição de renda e capital (MACHADO LIMA JUNIOR, 2013).

A partir dessa orientação keynesiana, Prebisch definiu seus conceitos de "ciclo-econômico" e "sistema centro-periferia". Por "ciclo-econômico" entende-se os impulsos constantes de expansão e contração da vida econômica em escala global. Tais impulsos seriam gerados nos países centrais (produtores de bens industrializados) e produziriam reflexos nos países periféricos (produtores de bens primários). Assim, a dicotomia centro-periferia seria o resultado histórico do modo como evoluiu o progresso técnico na economia global que repercutiu na diferenciação funcional complementar de estruturas produtivas no sistema econômico global. Por conseguinte, a divisão internacional do trabalho seria determinada segundo a distinção funcional entre centro e periferia na economia-mundo (MACHADO LIMA JUNIOR, 2013).

Jaguaribe complementa a teorização de Prebisch ao analisar os conflitos intrínsecos ao sistema político brasileiro que moldam a inserção da economia nacional na divisão internacional do trabalho. Segundo suas reflexôes, dois blocos teriam se polarizado na formação da nação brasileira em virtude da divergência sobre o posicionamento do país na economia-mundo. De um lado, o setor que o autor define como "atrasado" em virtude do seu vínculo com a manutenção da economia nacional em posição periférica. Nesse grupo estariam as oligarquias agrário-exportadoras, a burguesia mercantil, a classe média cartorial e o campesinato. De outro lado, o segmento "moderno" identificado com a transformação produtiva e a mudança de status da economia brasileira no sistema-mundo. A burguesia industrial, a classe média técnica e administrativa e o proletariado estariam nessa vertente. Jaguaribe via uma contradição no processo brasileiro de modernização na medida em que as instituiçôes democráticas liberais tinham o seu sentido subvertido pela ideologia e pelas práticas sociais e políticas legadas despotismo do período colonial. Seguindo essa lógica, os setores “atrasados” aparelhariam a burocracia estatal por meio de estratégias clientelistas de distribuição de benefícios em troca de apoio político e eleitoral (SOUZA \& SILVA, 2007) $\mathrm{O}$ autor destaca esse conflito no seguinte trecho de O Nacionalismo na Atualidade Brasileira:

O Estado brasileiro, desde a Colônia, tornou-se cartorial e assim persiste em nossos dias. Caracteriza-se o Estado cartorial por ser o instrumento de manutenção de uma estrutura econômico-social fundada numa economia primária de exportação e nos privilégios de classe a ela correlatos. Sua nota distintiva reside no fato de que o serviço público, em lugar de consistir no atendimento das necessidades coletivas, é um mecanismo de manipulação das clientelas eleitorais destinado a perpetuar os privilégios da classe dominante, proporcionando, sem a 
contrapartida da prestação de serviços efetivos e socialmente necessários, empregos e favores à clientela dos grupos dirigentes. (Jaguaribe, Hélio. O Nacionalimo na Atualidade Brasileira, pp 54-55)

Portanto, a construção de um projeto de desenvolvimento que atuasse na composição das importações e na diversificação das exportações de modo a equilibrar a balança comercial internacional dependeria da supressão do poder clientelista dos setores atrasados na máquina estatal e de um pacto entre as classes modernas entorno da ideologia do desenvolvimento autônomo. Para tanto, as classes "modernas" deveriam realizar uma reforma política institucional em resposta aos "pontos de estrangulamento" do desenvolvimento econômico resultantes da reprodução de práticas políticas herdadas do período colonial. Tais pontos de estrangulamento seriam referentes ao capital de investimento no setor produtivo e na infraestrutura para o desenvolvimento (SOUZA \& SILVA, 2007).

Em O Nacionalismo na Atualidade Brasileira (1958/2013), Jaguaribe argumenta sobre o papel positivo do capital estrangeiro para a solução dos referidos 'pontos de estrangulamento' do desenvolvimento nacional. Nesse sentido, o aporte do capital estrangeiro poderia proporcionar o aumento da capacidade de importação que iria repercutir no fortalecimento da indústria nacional e do mercado interno. Paradoxalmente, a entrada do capital externo estaria relacionada à proteção do sistema produtivo dos países centrais que teriam por objetivo a garantia de mercado para seus produtos, a exploração e controle das reservas naturais dos países periféricos - sob restrição de soberania nacional - e acesso a fatores de produção mais baratos (mão de obra e matéria prima (JAGUARIBE, 2013, p. 268). Perante esse paradoxo, um Estado Keynesiano Autônomo, comprometido com os setores progressistas da sociedade entorno da ideologia nacional-desenvolvimentista, poderia neutralizar os efeitos nocivos do capital externo e disciplinar o empresariado nacional para conter o efeito colonizador do financiamento externo (JAGUARIBE, 2013, p. 273)

No que tange à escassez de capital de investimento no setor produtivo, Jaguaribe ressalta as características manchesterianas do empresariado brasileiro dos anos 1950 que dispunha apenas do próprio capital e fundia as funções de investidor e empresário (JAGUARIBE, 2013, p. 273) A limitação ao próprio capital torna esse modelo de empresário incapaz de fazer os investimentos necessários para que o crescimento produtivo e a dilatação do mercado permitam que a capacidade de poupança do conjunto da população seja superior à capacidade de poupança e investimento da classe capitalista. Por consequência, é obstruída a transição do capitalismo manchesteriano para o capitalismo social no qual a base do sistema produtivo se move da 
poupança dos proprietários de capital para a progressiva acumulação de capital social. O duplo papel de empresário e financiador assumido pelo burguês manchesteriano tradicional brasileiro o induz a práticas de alta lucratividade por unidade de produto/serviço e de elevada concentração de capital. Como resultado, essa burguesia manchesteriana periférica atada a um estágio incipiente da modernidade tende a se afastar dos setores econômicos de base que são destinados ao capital estrangeiro ou ao Estado (JAGUARIBE, 2013, p. 274). Por outro lado, a burguesia tradicional se beneficia das práticas cartorias exercidas pelas elites tradicionais na burocracia estatal referentes à privatização dos lucros e socialização das perdas.

O conceito de socialização das perdas foi elaborado por Celso Furtado tendo como objeto de análise o período de monocultura cafeeira no Brasil altamente dependente do mercado externo. Durante esse período, em cenários de crise econômica internacional, o governo brasileiro promovia a desvalorização da moeda local perante a libra (adotada como padrão ouro) para evitar a queda do preço do café na moeda britânica. Desse modo, os lucros do setor exportador eram garantidos e os reflexos da crise nos países centrais eram transferidos para o mercado interno através do encarecimento de produtos importados (ALVARENGA JUNIOR \& MANSOR DE MATTOS, 2015). Furtado argumentava que essa transferência de perdas tinha efeito regressivo sobre a distribuição de renda e afetava de modo mais drástico as classes assalariadas em virtude da diferenciação de consumo de produtos importados por classe social:

Bastaria atentar na composição das importações brasileiras no fim do século passado e no começo deste, $50 \%$ das quais eram constituídas por alimentos e tecido, para dar-se conta do vulto dessa transferência. Durante a depressão, as importações que se contraíam menos - dada a baixa elasticidade-renda de sua procura eram aquelas de produtos essenciais utilizados pela grande massa consumidora. Os produtos de consumo de importação exclusiva das classes não assalariadas apresentavam elevada elasticidade-renda, dado seu caráter de não essencialidade. (Furtado, 1959/1967, p. 165)

Sob esse aspecto, a política tributária vinculada ao comércio exterior concorria para a socialização de perdas e crescimento das desigualdades sociais em cenários de crise internacional. Tal ocorria na medida em que o imposto sobre importação - cobrado em moeda nacional a uma taxa de câmbio fixa sobre o valor do produto - se mantinha estável quando havia alta de preços de produtos importados em virtude de crises internacionais. Assim, os consumidores nacionais de mercadorias de valores mais elevados eram menos onerados pela política tributária do que as classes que consumiam itens de menor custo (ALVARENGA JUNIOR \& MANSOR DE MATTOS, 2015). 
O modo produtivo brasileiro no século XXI adquire um status semiperiférico (permanecendo periferia do norte global e sendo centro perante países menos industrializados) Entretanto, a burguesia nacional preserva algumas características manchesterianas e mantém práticas de socialização de perdas e privatização de lucros promovidas por meio de açóes clientelistas e cartoriais das elites tradicionais nas instituiçóes políticas representativas. A política tributária adotada no Brasil desde o nacional-desenvolvimentismo dos anos 1950 até o pós-neodesenvolvimentismo desempenha um papel central na socialização deperdas e privatização de lucros na economia brasileira, bem como, no agravamento das desigualdades sociais. Ao invés de atenuar a desigualdade produzida pelas fontes primárias de geração de renda, o sistema tributário brasileiro tem assumido um efeito regressivo através do qual a participação dos tributos sobre a renda e o patrimônio dos indivíduos cresce em proporção inversa a estes. Assim, paga imposto relativamente mais alto quem possui renda menor (MANSOR DE MATTOS, 2017).

O modelo de desenvolvimento nacional posterior ao Golpe Militar de 1964 implementou uma política tributária que sobretaxou os salários dos trabalhadores ao mesmo tempo que ofereceu isençóes fiscais ao empresariado. Esta reforma tributária subsidiou a elevação do consumo das classes de rendas altas e médias-altas que proporcionou a acumulação de capital no período e concorreu para a sustentação do regime militar. Nos anos neodesenvolvimentistas, entre 2004 e 2013, apesar dos avanços em políticas distributivas e redução de desigualdades (Benefício de Prestação Continuada, Bolsa Família, etc.) houve uma transferência progressiva de ganhos da renda familiar para o setor financeiro no processo de mercantilização dos serviços públicos (MANSOR DE MATTOS, 2017). Assim, o pacto supraclassita (fundamental para a difusão da ideologia desenvolvimentista que promoveria a mudança de status do Brasil no sistema-mundo), vem sendo sistematicamente sabotado pelo cartorialismo das elites tradicionais até a crise do neodesenvolvimentismo.

Diante do cartorialismo da elite tradicional vinculada geopoliticamente às políticas protecionistas de países centrais que visam manter o país em condição periférica e impedir a socialização do capital, a perspectiva de desenvolvimento autônomo permaneceria um vetor da transformação do modo produtivo brasileiro na divisão internacional do trabalho. Nesse sentido, um Estado interventor forte, com instituiçóes representativas estruturadas de modo a coibir a sobre-representação cartorial das elites tradicionais e a acolher setores moderno da sociedade, poderia promover a mudança de status da economia nacional no sistema-mundo. 
Veremos adiante como o modelo de desenvolvimento autônomo proposto por Jaguaribe apresenta respostas à crise estrutural do capitalismo global no século XXI - marcada pela elevação progressiva da pobreza e da concentração de capital, que conduz à estagnação da demanda e à crise de legitimidade democrática. $\mathrm{O}$ avanço global da austeridade neoliberal concomitante ao crescimento de grupos políticos neofascistas - que resultam em uma política externa protecionista das economias do norte em relação ao sul global - constituem uma oposição ao modelo de desenvolvimento sustentável, distributivo e inclusivo defendido pelos atores de governança global. Nesse cenário, o modelo de desenvolvimento autônomo dos Estados - sobretudo, do sul global - oferece condiçôes para a realização de acordos multilaterais que horizontalizem a globalização e promovam as mudanças no modelo de desenvolvimento global em resposta aos seus desafios estruturais.

\section{OS IMPACTOS DA AUSTERIDADE NEOLIBERAL SOBRE A CRISE ESTRUTURAL DO CAPITALISMO GLOBAL NO SÉCULO XXI}

As teses sobre a consolidação do liberalismo econômico como única e definitiva alternativa para o sistema econômico global se projetaram a partir da dissolução do regime socialista. O slogan There is no alternative, da primeira ministra britânica Margareth Thatcher, e a Teoria do Fim da História, do filósofo e economista Francis Fukuyama, sintetizam as referidas teses que foram assimiladas pela 'serie de governos de orientação neoliberal que conquistaram o poder na Europa e nos EUA ao longo dos anos 1980 (MACHADO LIMA JUNOR, 2020).

A idéia defendida por Thatcher e Fukuyama de que a complementaridade entre liberalismo econômico e democracia liberal constituiriam um regime político-econômico que se tornaria global foi inspirada no pensamento de Herbert Spencer. Em Social Statics (Spencer,1851/2020), a negação a todas as restriçốes comerciais baseava-se na defesa moral e prática dos direitos individuais entendidos como 'liberdades comuns". Desse modo, o slogan da premier britânica exprimia a noção de que o livre mercado seria a forma mais eficaz de construir a riqueza, distribuir os serviços e expandir a economia das sociedades a partir da fase pós industrial do capitalismo. Em diálogo com essa perspectiva, Fukuyama (1982) fundamenta sua teoria sobre o fim da história no argumento filosófico de Hegel, pela interpretação de Alexandre Kojève (2002), de que a ascensão do liberalismo e da igualdade jurídica levariam a humanidade a atingir o equilíbrio entre seus antagonismos acarretando o fim dos processos históricos de mudança, o que significaria o fim da história. (Anderson, 1992). 
Tanto para Hegel quanto para Marx a evolução das sociedades humanas não era ilimitada. Mas terminaria quando a humanidade alcançasse uma forma de sociedade que pudesse satisfazer suas aspirações mais profundas e fundamentais. Desse modo, os dois autores previam o 'fim da História'. Para Hegel seria o estado liberal, enquanto para Marx seria a sociedade comunista. (FUKUYAMA, 1992, p. 12)

Com base nessa premissa hegeliana, Fukuyama defende que a democracia liberal seria o estágio evolutivo mais perfeito da humanidade no qual o fascismo e o socialismo (por ele definidos como experiências totalitárias) teriam sido suplantados Assim, a luta de classes estaria resolvida por meio de um regime político que distribuísse de maneira justa o acesso aos direitos sociais e as oportunidades de sucesso material. (MACHADO LIMA JUNIOR, 2020)

Dos diferentes tipos de regimes surgidos no curso da história da humanidade, desde monarquias e aristocracias até as teocracias religiosas e as ditaduras fascistas e comunistas deste século, a única forma de governo que sobreviveu intacta até o fim do século XX foi a democracia liberal. (FUKUYAMA, 1992, p. 80).

Perry Anderson analisa que embora tenha adquirido maior projeção a partir da decadência do socialismo real, o neoliberalismo surgiu logo no início da Guerra Fria como uma reação ao intervencionismo estatal e à construção do Estado de Bem Estar na Europa do Pós Guerra. A obra de origem do pensamento neoliberal, em distinção ao liberalismo clássico, é $O$ Caminho da Servidão, de Friedrich Hayek (1944) a qual sustenta que tanto o socialismo quanto o nazismo e o fascismo, assim como o Estado previdenciário, conduziriam ao cerceamento da liberdade dos indivíduos e, por conseguinte, ao totalitarismo. Sob essa ótica, o planejamento estatal e o Estado Keynesiano teriam um componente totalitário na medida em que o controle econômico que propóem tenderia a paralisar as forças dinâmicas da sociedade impedindo a formação de uma sociedade livre. Nas palavras de Hayek, " a ascensão do nazismo e do fascismo não foi uma reação contra as tendências socialistas do período precedente, mas o resultado necessário dessas mesmas tendências" (Hayek, 1944/2010).

Entorno das ideias de Hayek, reuniram-se intelectuais que se opunham tanto ao Welfare State Europeu quanto aos programas assistenciais do capitalismo keynesiano implementado pelo presidente Roosevelt nos EUA. Entre tais intelectuais podemos destacar Milton Friedman, Karl Popper, Walter Lipman e Michael Polanyi. (ANDERSON, 1995). Contudo, a repercussão de suas críticas antisocialistas e antikeynesianas foi reprimida pelo avanço do capitalismo internacional de forma associada à consolidação democrática e ao Estado de Bem Estar durante as décadas de 1950 e 1960 (ANDERSON, 1995). 
A expansão concomitante do keynesianismo e do fordismo/taylorismo em escala global, entre as décadas de 1940 e 1980, promoveu o empoderamento do trabalho sobre o capital através da cooperação entre sindicatos, setores produtivos e o Estado (MOTA, 2013). Contudo, a diversificação da demanda, gerada pelo modelo fordista-taylorista (que marcou o modo de produção capitalista durante os anos keynesianos) levou o capitalismo global a uma crise estrutural mediante a incapacidade do modo de produção capitalista em atender à pluralidade da demanda por ele próprio gerada. Essa crise estrutural, ao lado da derrocada do socialismo real, criou oportunidades políticas de expansão do discurso neoliberal a partir dos anos 1980 (MACHADO LIMA JUNIOR, 2020)

A crise financeira de 2008, nos EUA, que teve reflexos na crise financeira na Europa em 2010, deu novo impulso à austeridade neoliberal. A dificuldade em retomar o crescimento produtivo, motivou a criação de inovações financeiras como forma de estimular o consumo sem aumentar a produção. Tais inovações eram baseadas em linhas de cartão de crédito, hipotecas e tipos diversos de flexibilização de endividamento. (MOTA, 2013) Essas reformas configuraram um tipo de capitalismo que tinha como fonte principal de lucro e mais valia o crédito em si mesmo ao mesmo passo em que era marcado por estagnação salarial e precarização das relações de trabalho. Essa nova fase do capitalismo foi denominada pelo sociólogo Zygmunt Bauman de "capitalismo parasitário" (BAUMAN, 2010). Nessa fase do capitalismo, o endividamento permanente e a constante transferência de parte da renda dos trabalhadores para o sistema bancário, sob a forma de juros bancários, são elementos fundamentais para a manutenção da capacidade de auto-reprodução do sistema (MOTA, 2013).

Nos Estados Unidos, o endividamento médio das famílias cresceu algo em torno de $22 \%$ nos últimos oito anos - tempos de uma prosperidade que parecia não ter precedente. A soma total das aquisições com cartôes de crédito não ressarcidas cresceu $15 \%$. E a dívida, talvez ainda mais perigosa, dos estudantes universitários, futura elite política, econômica e espiritual da nação, dobrou de tamanho. O adestramento para a arte de "viver em dívida" e de forma permanente foi incluído nos currículos escolares nacionais. A Grã-Bretanha também chegou a situação bem semelhante. Em agosto de 2008, a inadimplência dos consumidores superou o total do Produto Interno Bruto da GräBretanha. As famílias britânicas têm dívidas num valor superior a tudo o que suas fábricas, fazendas e escritórios produzem (BAUMAN, 2010, p. 20).

A precarização das relaçóes de produção que marca o capitalismo parasitário - na definição de Bauman - ou capitalismo financeirizado - termo utilizado por Harvey (2011) para designar o mesmo fenômeno - é fruto 
da flexibilização econômica promovida pelo neoliberalismo e da destruição parcial do Estado de Bem Estar.

Do ponto de vista do regime democrático, as crises financeiras de 2008 e 2010 impactaram na crise de legitimidade dos partidos de esquerda (MOTA, 2013). Tal ocorreu porque tanto o governo democrata de Barack Obama, nos EUA, quanto os partidos socialistas e sociais democratas europeus, procuraram solucionar a crise através de políticas públicas voltadas para sanear os bancos em detrimento das necessidades do conjunto da população.

A perda da referência dos partidos socialistas e sociais democratas como antítese ao neoliberalismo leva a polarização do debate político entre extrema direita e extrema esquerda no que tange à perspectiva de auto-representação do povo. (GERBAUDO, 2017).

O crescimento contínuo da concentração de capital e, por conseguinte, das desigualdades sociais, no capitalismo mundial durante os dois últimos séculos se fundamenta na superação da taxa de retorno sobre o capital em relação à taxa de crescimento da renda (PIKETTY, 2014). Esse fenômeno de privatização de capital em escala global configura uma contradição na medida em que, de acordo com o pensamento econômico neoclássico, a auto-reprodução e expansão do sistema dependem do crescimento da renda. (HARVEY, 2014) Contudo, o recrudescimento das desigualdades a partir da expansão da austeridade neoliberal, iniciada nos anos 1980, tem bases no desequilíbrio de poder entre capital e trabalho. Sob a ótica marxista, a organização e a ação coletiva da classe trabalhadora (dentro de um sistema democrático liberal em que as instituiçôes representativas sejam reconhecidas como legítimas) constituem uma oposição às estratégias, tanto do Estado quanto do mercado, que impeçam a socialização do capital. De modo contrário, os governos neoliberais implementaram políticas de redução de custos de produção através do aumento do desemprego (para ampliação de exército industrial de reserva), da perda de direitos trabalhistas e da redução salarial. Essas medidas, declaradas anti-inflacionárias, enfraqueceram politicamente a classe trabalhadora e, por conseguinte, facilitaram a sobre-representação política dos donos do capital (Harvey, 2014).

Com o objetivo de elevação da privatização dos lucros sem antagonismos de classe, reduzindo empregos e rebaixando salários, o neoliberalismo prejudica a médio e longo prazos a possibilidade de auto reprodução e ampliação do crescimento econômico porque restringe a capacidade de consumo do mercado. A premissa de que a escassez de demanda efetiva estaria na base da grande depressão econômica da década de 1930 inspirou a expansão das políticas keynesianas, entre o fim da Segunda Guerra Mundial e os anos 1980, 
marcadas pela elevação da renda direta (salários) e indireta (Estado de Bem Estar Social), estabilidade democrática e empoderamento político da classe trabalhadora. Esse conjunto de políticas resultou na redução das desigualdades sociais e na retomada do crescimento produtivo tendo como apoio financeiro a tributação progressiva conforme a renda (WOLF, 2019) Com o fim do socialismo real e a ascensão globalização neoliberal houve a reformulação da política tributária, que tornou-se regressiva sem se traduzir em crescimento produtivo, bem como, a perda de legitimidade das democracias liberais e o crescimento da pobreza em escala global. Comparados o período keynesiano e o neoliberal, podemos observar que entre 1948 e 1973, a renda familiar média real nos Estados Unidos crescia a 3\% ao ano. Durante esse período, havia $96 \%$ de chance de que um indivíduo tivesse uma renda superior a de seus pais. A partir de 1973, a média de crescimento da renda familiar passou a crescer a $0,4 \%$ ao ano. Nessa nova realidade, $28 \%$ dos trabalhadores passaram a ter a renda inferior a de seus pais (WOLF, 2019). A análise comparativa destes processos político-econômicos indica para a centralidade da taxação progressiva e da tributação da riqueza global para a regulação da patrimonialização do capitalismo global, ou, nos termos de Celso Furtado, privatização de lucros e socialização de perdas em escala global.

O economista Paul Kurgman (2018) analisa como as políticas de baixa tributação e auto regulação do mercado do Estado Mínimo Neoliberal nos EUA, desde os anos 1980, têm se refletido em um crescimento econômico pífio e na redução da renda da classe trabalhadora. O autor destaca a importância da regulação estatal sobre o mercado para conter a elevação progressiva da concentração de capital provocada pela formação do monopsônio. De modo inverso ao monopólio, no qual apenas um produtor/vendedor controla o mercado, o monopsônio ocorre quando uma única empresa compradora (monopsolista) detém o mercado. Essa prática, além de controlar os preços, vem reduzindo salários e contratação de trabalhadores. Como solução para as contradições neoliberais, Krugman indica o empoderamento do trabalho (sindicatos, associações, fóruns, etc) sobre o capital tendo por base a ação de um Estado Keynesiano que regule as relaçôes trabalhistas e garanta os direitos de organização e ação política da classe trabalhadora.

A retração da socialização de capital causada pelas práticas neoliberais de eliminação da concorrência no mercado, fraco crescimento produtivo e tributação regressiva tem repercutido sobre a crise de legitimidade das democracias liberais no início do século XXI. A falta de regulação estatal sobre fusões e práticas anticompetitivas, assim como, sobre meio ambiente e relaçóes trabalhistas fomenta o descrédito dos trabalhadores e dos cidadãos comuns 
quanto ao sistema representativo por verem seus interesses serem sub-representados perante o lobby das corporações econômicas (Wolf, 2019).

As reformas que caracterizam o neoliberalismo - privatização de empresas públicas, flexibilização das relações produtivas, redução salarial, austeridade fiscal, tributação regressiva, etc. - têm sido realizadas em países europeus desde os anos 1980 tanto por governos de direita quanto de esquerda. Diante dessa realidade, o cidadão comum encontra dificuldade em diferenciar governos de esquerda e direita, no que tange às políticas econômicas, na medida em que o projeto neoliberal vem se perpetuando acima das divergências partidárias. Nesse contexto, o sistema representativo se configura como uma instância inacessível aos interesses populares aparelhada por uma elite que governa para si própria (MOUNK, 2018). O sistema democrático, como um todo, enfrenta uma crise de legitimidade que não se limita às instituições representativas, mas se estende a todo o repertório de açóes coletivas correspondente à democracia liberal. Desse modo, caem em descrédito popular os partidos políticos, as associaçôes de moradores, os diretórios estudantis, os grupos de minorias e os diversos coletivos. Por conseguinte, cresce a ideia no conjunto da população de que é necessário dissolver as instituiçóes democráticas e substituí-las pela auto-representação do povo, seja através de um indivíduo que se apresente como o líder carismático ou através da própria massa popular que se auto-configure como uma liderança carismática. Essa ideia de auto representação insufla tanto movimentos de extrema direita - de orientação ultranacionalista e neofascista - quanto movimentos de extrema esquerda - de perspectiva emancipatória, autonomista e neoanarquista - que confrontam o sistema democrático liberal por lados opostos. (MACHADO LIMA JUNIOR, 2020)

Diante da ascensão de governos de extrema direita com contornos fascistas ao redor do globo no início do século XXI, sem precedentes desde os anos 1930, o sociólogo William Robinson (2012) analisa a aliança entre o Estado e o capital entorno do projeto fascista. Nessa aliança, a elevação de concentração de capital, por meio de tributação regressiva e redução de empregos e salários (que leva a uma crise estrutural por estagnação do consumo), é exercida com o cerceamento do Estado Democrático de Direito e repressão política estatal. Enquanto no século XX a coligação fascista era entre Estado e capital nacional, no século XXI tornou-se entre poder público local e o capital transnacional - o que proporciona uma sobre-acumulação global de capital para além dos limites dos Estados Nacionais, dá uma propensão global ao projeto fascista e conduz a uma segunda da crise estrutural da demanda. Sob outro aspecto, o projeto fascista tem maior força de 
implementação no século XXI do que nos anos 1930 em virtude do enfraquecimento dos sindicatos, associações de trabalhadores e da ideologia socialista. (ROBINSON, 2012)

Alguns dos princípios clássicos do fascismo se mantêm na feição com que esse regime se mostra no século XXI. Entre os quais: a ideia de unidade nacional acima das individualidades e diferenças sociais; a auto-representação popular (sob a liderança carismática) em detrimento das instituições democráticas; a mobilização emocional das massas pela construção social do ódio; o autoritarismo; e o belicismo. Entretanto, as novas formas de controle social e dominação ideológica através das mídias digitais tornam difusas as fronteiras do autoritarismo e geram oportunidades para uma forma de fascismo constitucional (com instituições representativas formais, partidos políticos e eleiçôes) sob o controle do capital global e seus representantes (ROBINSON, 2012).

Nessa sessão, pretendemos fazer uma análise do processo político-econômico marcado pelo neoliberalismo e seus reflexos sobre a assimetria da divisão interncaional do trabalho, bem como sobre o empoderamento do capital perante o trabalho, a estagnação da demanda e a privatização do capital em escala global. Veremos a seguir, que respostas o modelo de desenvolvimento autônomo tem a oferecer à crise de legitimidade das democracias liberais e aos problemas estruturais do modelo de desenvolvimento global.

\section{INTERFACES ENTRE O DESENVOLVIMENTO AUTÔNOMO E O NEOKEYNESIANISMO GLOBAL EM PROL DO DESEN- VOLVIMENTO}

Diante da nova crise da demanda e da ascensão do neofascismo global, atores econômicos globais de orientação reformista - como George Soros, Joseph Stiglitz, Jeffrey Sachs e representantes políticos que se distanciam do pensamento econômico neoclássico - propóem uma regulação global dos mercados financeiros (ROBINSON, 2012). Além disso, sugerem intervençôes estatais, coordenadas em escala global, de transição da acumulação de capital do setor especulativo para o setor produtivo. Esses agentes defendem o Neokeynesianismo Global e compartilham a perspectiva distributiva através de uma tributação progressiva sobre as grandes fortunas em escala global análogas às análises de Wolf, Piketty, Krugman, e Harvey.

Tal como no keynesianismo que sucedeu à crise mundial da década de 1930, o Neokeynesianismo Global reconhece a complementaridade entre liberalismo e democracia e propóe, nesse sentido, que o fortalecimento 
do Estado Nacional passe pela legitimação da sua governança. Portanto, a administração pública deve promover a ampliação da participação das bases populares nos processos deliberativos e consultivos. Assim, a ameaça à estabilidade das instituições democráticas impulsionada pela ideia neofascista de auto-representação popular seria contida pelo reequilíbrio da relação entre capital e trabalho sob o controle do Estado Neokeynesiano Global.

A agenda de um modelo de desenvolvimento global distributivo (por meio de tributação progressiva e equilíbrio entre trabalho e capital), sustentável e democrático é assumida por instituições de governança global (como a ONU, OCDE, o Tribunal Penal Internacional, etc.) na organização de acordos transnacionais em resposta à crise estrutural do capitalismo no século XXI. Entretanto, a capacidade política desses atores enfrenta obstáculos causados pelo avanço da aliança entre neofascismo e neoliberalismo no sistema representativo das democracias ocidentais. Governos ultra-nacionalistas do norte global tendem a se opor ao multilateralismo trazido pela governança global e defendem acordos unilaterais que protejam o status de centralidade de suas economias no sistema mundo. Esses acordos unilaterais, que mantém as economias do sul global em condição periférica, são viabilizados a nível local através de práticas cartoriais na burocracia estatal exercidas pelas elites tradicionais ligadas ideológica e financeiramente ao protecionismo do norte global - um processo de globalização neofascista que se opóe ao Neokeynesianismo Global (ROBINSON, 2012).

Diante do antagonismo entre esses modelos de globalização, os elementos constitutivos da noção de desenvolvimento autônomo de Hélio Jaguaribe têm respostas a oferecer à crise estrutural do capitalismo no século XXI, bem como, à mudança de status das economias do sul global na divisão internacional do trabalho. Entre tais respostas, indica a centralidade de um Estado Keynesiano forte para articular um pacto supraclassista entre os setores modernizadores da sociedade de modo a definir uma ideologia desenvolvimentista e a suprimir o clientelismo das elites tradicionais - e, por conseguinte, coibir a interposição a nível local do neofascismo global.

$\mathrm{Na}$ visão de Jaguaribe, a mudança do modo produtivo periférico seria induzida pelo planejamento do Estado Autônomo através da entrada de capital externo de maneira a fortalecer o mercado interno e alterar a inserção do país na divisão internacional do trabalho. Nesse sentido, na geopolítica do início do século XXI, o modelo de desenvolvimento autônomo seria fundamental para garantir a capacidade política deliberativa de socialização de capital estabelecidas pelos Atores de Governança Global no que se refere à tributação progressiva em escala global e equilíbrio político entre capital e trabalho. O que tornaria esse modelo tão central para as deliberações 
distributivas em escala global seria o seu potencial político de enfrentamento do neofascismo global.

Nessa conjuntura global, assim como o equilíbrio entre capital e trabalho seria central para conter o avanço do neofascismo, o equilíbrio entre local e global (com o fortalecimento das instituiçôes democráticas dos Estados Nacionais) seria fundamental para a governança global em prol do neokeynesianismo global - de modo análogo à descrição de Otávio Ianni sobre as teorias da globalização (IANNI, 1996).

No que tange à complementaridade entre liberalismo econômico e democracia, o princípio de transformação produtiva com equidade social, incorporado à noção de desenvolvimento autônomo por Hélio Jaguaribe, traz uma sólida contribuição à resposta do neokeynesianismo global para a crise das democracias liberais. Por esse princípio, a distribuição de bens e serviços públicos, acrescida do aumento da renda do conjunto dos trabalhadores, seria uma pré-condição para a substituição de importaçôes através da consolidação da capacidade de auto reprodução das atividades econômicas, bem como, para a estabilização do sistema democrático. Essa visão de complementaridade entre desenvolvimento econômico, aperfeiçoamento do sistema democrático e mecanismos distributivos foi legada por Hélio Jaguaribe (e os intelectuais do Iseb) à definição do neodesenvolvimentismo brasileiro e incorporada às estratégias de inovação em administração pública na Europa no início do século XXI (MACHADO LIMA JUNIOR, 2020). Um dos principais alicerces do modelo neodesenvolvimentista consistia na ampliação das instituiçóes participativas como forma de aperfeiçoar o sistema representativo e conferir maior legitimidade às políticas de Estado. Desse modo, o sistema democrático brasileiro estaria baseado na interação recíproca entre o sistema representativo, o sistema participativo e o controle das burocracias (MACHADO LIMA JUNIOR 2015).

Diante do processo de redução da participação dos eleitores e da perda da confiança da população nas instituiçóes públicas, que se agravou na Europa pelos impactos sociais e políticos do avanço da austeridade neoliberal, houve uma apropriação das propostas participativas neodesenvolvimentistas por parte dos governos europeus no nível das administraçóes regionais (MACHADO LIMA JUNIOR, 2020). Importantes centros urbanos - Paris, Londres, Berlim, Milão, etc. - inovaram suas estruturas burocráticas por meio de mecanismos participativos inspirados no neodesenvolvimentismo brasileiro - sobretudo na experiência do orçamento participativo (SINTOMER, HERZBERG \& ROCKE, 2012).

Através do Orçamento Participativo os cidadãos comuns podem participar da administração pública no que se refere à distribuição dos fundos 
públicos. A estrutura de funcionamento do Orçamento Participativo adotada nos governos regionais europeus representa uma evolução em mecanismos de participação democrática institucional no que tange à digitalização dos canais participativos. Essa inovação tecnológica permite que o conjunto da população colabore de modo on-line com a gestão e aplicação dos recursos públicos - através de chatbots, pautas digitais e transmissóes on-line ao vivo das plenárias em mídias digitais - de modo conciliado com atividades presenciais (MACHADO LIMA JUNIOR, 2020). Em 2012, foram registradas cerca de quatrocentas plataformas e ferramentas digitais adotadas em cidades europeias na Europa por incentivo de governos e órgãos públicos (SINTOMER, HERZBERG \& ROCKE, 2012).

A ampliação da inserção dos cidadãos comuns nos processos deliberativos de políticas de Estado através de instituições participativas desconstrói a ideia de que as democracias liberais formam elites que governam para si próprias e, nesse sentido, contribui para a restituição da legitimidade do sistema democrático. Sob outro aspecto, a participação democrática institucional tem o efeito de contenção do neofascismo na medida em que esvazia a perspectiva auto representação popular e fortalece as instituições políticas.

\section{CONSIDERAÇÕES FINAIS}

O Neokeynesisanismo Global demonstra que a proposta neoliberal de flexibilização das relaçốes de trabalho como forma de dinamizar a economia leva o capitalismo global a uma nova crise da demanda. Como antítese, indica o empoderamento do trabalho sobre o capital como meio de estabelecer um equilíbrio democrático que contenha o avanço do neofascismo global e permita aos Estados Nacionais, interativos em uma governança global, fazer as reformas distributivas necessárias a solucionar a crise estrutural do capitalismo global. Os princípios constitutivos do desenvolvimento autônomo são fundamentais para essa inversão na relação entre capital e trabalho porque enfrenta os mecanismos locais da austeridade neoliberal em escala global. Como resposta à sedução das massas populares ao neofascismo global, o desenvolvimento autônomo propóe a participação democrática institucional e a conexão entre democracia direta e sistema representativo. A perda de legitimidade das democracias liberais provocada pela sobre representação neoliberal foi estendida ao repertório de ação coletiva da democracia. O desenvolvimento autônomo resgata a centralidade das formas desse repertório - os sindicatos, os partidos políticos, as associações de moradores, os grêmios e diretórios estudantis, etc.- para a reforma e auto-reprodução do desenvolvimento global. 


\begin{abstract}
Notas
'O ISEB (Instituto Superior de Estudos Brasileiro) foi criado em 1955 como órgão do Ministério da Educaçãoe Cultura. O grupo de intelectuais que o criou tinha como objetivos o estudo, o ensino ea divulgação das ciências sociais, cujos dados e categorias seriam aplicados à análise e à compreensão crítica da realidade brasileira e deveriam permitir o incentivo e a promoção do desenvolvimento nacional.' Acessível em: https://cpdoc.fgv.br/producao/dossies/JK/artigos/Economia/ISEB.

2 "Expressão cunhada e conceito desenvolvido por Hélio Jaguaribe em seu trabalho "Política ideológica e política de clientela", publicado no Jornal do Comércio de 14/5/1950 e em Digesto Econômico, São Paulo, 6 (68): 41-62, julho.
\end{abstract}

\section{Referências}

AFTER PARIS. Inequality, Fair Shares, and the Climate Change Emergency. Civil Society Equity Review. December, 2018.

ALVARENGA JUNIOR, $M$; MANSOR DE MATTOS, F. A. O conceito de socialização de perdas e seu papel na discussão da questão distributiva na obra Formação Econômica do Brasil, de Celso Furtado. Cadernos do Desenvolvimento. Rio de Janeiro. v. 15, n. 17, pp. 11-25. 2015.

ANDERSON, P. "Balanço do Neoliberalismo". In SADER, Emir \& GENTILLY, Pablo (orgs) Pós Neoliberalismo: as políticas sociais e o Estado democrático. Rio de Janeiro: Paz e Terra, 1995.

BAUMAN, Z.. Capitalismo Parasitário. Rio de Janeiro: Ed. Zahar, 2010.

BOSCHI, R.. Periphery and Semi-periphery. Ed. Routledge. (2012). New York.

FUKUYAMA, F. The End of History and the Last Man. New York: Free Press, 2006

FURTADO, C.. Formação Econômica do Brasil. Cia Editora Nacional: São Paulo, 1959/1967.

GERBAUDO, P. The Mask and the Flag. Oxford University Press, 2017.

GRAEBER, D. The New Anarchists. New Left Review. 13. January-February, 2002.

HARVEY, D. A Brief History of Neoliberalism. Oxford: Oxford University Press, 2005.

HARVEY, D. Afterthoughts on Piketty`s Capital. Acessível em: http://davidharvey. org/2014/05/afterthoughts-pikettys-capital/
HARVEY, D. O enigma do capital: e as crises do capitalismo. São Paulo: Boitempo, 2011.

HAYEK, F. A. O Caminho da Servidão. São Paulo: Instituto Ludwig von Mises Brasil, 2010.

IANNI, O. Teorias da Globalização. Rio de Janeiro: Ed. Civilização Brasileira, 1996.

JAGUARIBE, H. "ISEB - Um breve depoimento e uma reapreciação crítica". Cadernos do Desenvolvimento, v. 9, n. 14, pp.231 260. Jan-Jun. 2014.

JAGUARIBE, H. O Nacionalismo na Realidade Brasileira. Brasília: Funag, 2013.

KOJÉVE, A. Introdução à leitura de Hegel. Trad. Estela dos Santos Abreu. Rio de Janeiro: Contraponto/EDUERJ, 2002.

KRUGMAN, P. Capitalism, Socialism and Unfreedom. New York Times. Aug. 26, 2018

LACLAU, E. A Razão Populista. São Paulo: Ed. Três Estrelas, 2013.

MACHADO LIMA JUNIOR, H. A Ressignificação da Dependência no Novo-Desenvolvimentismo Brasileiro. Ponto de Vista, n. 9, Setembro, 2013.

MACHADO LIMA JUNIOR, H. (2020). "As Contribuições do Ipea para a legitimidade da Democracia Liberal". In: Titonelli Nunes, B. \& Cardoso Junior, J. Celso; Org.). Ipea diante do espelho: Contribuições da Afipea-Sindical para reflexão e desenvolvimento Institucional. Brasília: Afipea, 2020.

MACHADO LIMA JUNIOR, H. Participação 
Democrática e Justiça Distributiva para o Desenvolvimento: a definição ideológica do neodesenvolvimentismo pela DIEST/IPEA entre 2010 e 2012 e sua tradução em políticas públicas. Ponto de Vista, n. 6, Dezembro, 2015. Rio de Janeiro.

MANSOR DE MATTOS, F. A.. "O debate sobre distribuição de renda ao longo do processo de desenolvimento econômico do Brasil". Revista da ABET, v. 16, n. 1, Jan-Jun. 2017.

MOTA, L. A. Os movimentos sociais na crise financeira global: questões e polêmicas. Unisinos, v. 49, n. 3, pp. 288-296, Setembro/ Dezembro 2013.

MOUNK, Y. The People vs. Democracy: Why our freedom is in danger. Cambridge: Harvard University Press, 2018.

OFFE, C. Trabalho: uma categoria chave da sociologia?. In: Offe, C. (org.) Trabalho e sociedade: problemas estruturais e perspectivas para o futuro da Sociedade do trabalho. Rio de Janeiro: Tempo Brasileiro, 1989

PIKETTY, T. Capital in the Twenty-First Century. Cambridge: Belknap Press of Harvard University, 2014.
ROBINSON, W. \& BARRERA, M. Global Capitalism and twennty-first century fascism: a US case study. Race and Class. Institute of Race Relations, v. 53m n. 3, pp. 4-29, 2012.

SINTOMER, Y; HERZBERG, C. \& RÖCKE, A. Modelos Transnacionais de Participação Cidadã: o Caso do Orçamento Participativo. Sociologias, Porto Alegre, ano 14, n. 30, maio-ago, 2012, pp. 70-116.

SGI. Policy Performance and Governance Capacities in the OECD and EU Sustainable Governance Indicators 2018.

SOUZA E SILVA, C. A. Reforma Política e Desenvolvimento em Hélio Jaguaribe. CS Online - Revista Eletrônica de Ciências Sociais. Novembro, 2007.

SPENCER, H. Social Statistics. New York Robert Schalkenbach Foundation, 2020.

WOLF, M. Why rigged capitalism is damaging liberal democracy. Financial Times. September, 2019. 


\title{
Helio Jaguaribe and Brazil ‘s Oil Question
}

\author{
Helio Jaguaribe e a questão do \\ petróleo no Brasil
}

\author{
Francisco Ebeling*
}

\begin{abstract}
When Helio Jaguaribe published his book "O nacionalismo na atualidade brasileira" (Nationalism in Brazil Today), its impact in Brazil's developmental epistemic community was immediate. Among the nationalists who strongly advocated the 1953 Petrobras oil monopoly, the reaction was one of astonishment and outrage. In this article, it is argued that Jaguaribe did not seek to question the adequacy of the monopoly solution, but rather to frame the debate about the oil question on a more rational and pragmatic basis. Jaguaribe's pioneering contribution would be followed by a rich intellectual debate of some decades between sociologists, political scientists, and economists about the significance of the Brazilian oil issue and the importance of the foundation of Petrobras in 1953 for economic development and Brazil's affirmation in its quest for economic and political independence. The article also shows that at various times of his career Jaguaribe would return to the oil question, emphasizing in a lucid and pragmatic way, and, above all, imbued with a developmental spirit, its challenges, and possible solutions.
\end{abstract}

Keywords: oil question, Hélio Jaguaribe, nationalism, Petrobras, industrialization

\begin{abstract}
Resumo
Quando Hélio Jaguaribe publicou seu livro "O nacionalismo na atualidade brasileira", seu impacto na comunidade epistêmica desenvolvimentista foi imediato. Em particular, entre os nacionalistas que defendiam arduamente o monopólio da exploração petrolífera da Petrobras, concedido em 1953, a reação foi de espanto e indignação. Neste artigo argumenta-se que na realidade Jaguaribe não buscou questionar a adequação do monopólio, mas sim posicionar o debate sobre a questão petrolífera em bases mais racionais e pragmáticas. À contribuição pioneira de Jaguaribe seguir-se-ia um rico debate intelectual de algumas décadas entre sociólogos, cientistas políticos e economistas acerca do significado da questão petrolifera brasileira e sobre a importância da fundação da Petrobras em 1953 para o desenvolvimento econômico do país e para sua independência política e econômica. $O$ artigo também mostra que em vários momentos de sua carreira Jaguaribe voltaria à questão petrolifera, ressaltando de forma lúcida e pragmática, e, acima de tudo, imbuído de um espírito desenvolvimentista, os desafios que se punham e possíveis soluções.
\end{abstract}

Palavras-chave: questão petrolifera, Helio Jaguaribe, nacionalismo, Petrobras, industralização,

\footnotetext{
* Candidato a Doutor, Instituto de Economia, Carl von Ossietzky Universität Oldenburg, Oldenburg, Alemanha. https://orcid.org/0000-0002-2502-4338. E-mail: ebelingbarros@gmail.com
} 


\section{INTRODUCTION}

In 1958, when Helio Jaguaribe published his "O nacionalismo na atualidade brasileira” (Nationalism in Brazil Today) (Jaguaribe 1958), the Brazilian developmental debate was still in full swing. Although Petrobras had been founded in 1953, giving a more nationalistic solution to the Brazilian oil question, and, despite the already felt success of the diverse attempts to plan Brazil's economic development, some very pressing issues had not been entirely answered. How would the development and expansion of the Brazilian electricity sector take place, with a state-owned company that coordinates the expansion, or with public and/or private companies performing such a function? What would be the role of international private capital in promoting Brazilian development? Would this sector assume the responsibility of steering the rise of the durable goods sector, or would national capitalists have the financial breath and technological capabilities to achieve higher flights?

In his national-bourgeois interpretation of the Brazilian economic development process, Hélio Jaguaribe had an arsenal of answers to these questions. For Jaguaribe, considered ISEB's main theoretical formulator and also its most reputed political scientist, it was clear that the most appropriate model for advancing Brazil's development after 1930 would bea nationalistic brand of capitalism" (BRESSER PEREIRA, 1997, p. 20). In this development project, a class of entrepreneurs from the national bourgeoisie, which "would be nationalist, industrializing, modern and socially progressive, would have a leading role, but would be "captained by the state, which emerges as the coordinator of the entire economy" (MANTEGA, 1991, p. 60). Nevertheless, in analyzing the resolution of the Brazilian oil question, with the foundation of Petrobras in 1953, Jaguaribe concludes that the monopoly solution would require that the nation would not give up foreign capital in other sectors of the economy, due to a scarcity of resources. This position, considered overtly pragmatic what concerns the issue of foreign capital by the most radical nationalists, leads to Jaguaribe's and his associates' resignation from ISEB (SMITH, 1976)

In this article, it is argued that while Jaguaribe's interpretation of the Petrobras foundation contains some misconceptions, it has the undeniable merit of having placed the debate on Brazil's oil question on a much more pragmatic and realistic base. Moreover, it is shown that Jaguaribe was the main forerunner of a series of high quality and more rigorous academic interpretations about this question. The article also reviews Jaguaribe's other contribution to the oil problematic (1974; 1977; 1989), considering their historical context. 
The rest of the article is organized as follows. The first section describes the resolution of the Brazilian oil question, which would culminate in a nationalist solution, with Petrobras the founding of Petrobras in 1953. The second section analyzes the pioneering contribution of Jaguaribe to understanding the importance of this issue and reviews the other contributions that followed in the debate. Finally, the third and last section reviews Jaguaribe's other contributions to the oil subject considering their historic meaning.

\section{THE SETTLING OF THE OIL QUESTION IN BRAZIL}

After taking office for a second term (1951-1954), Getulio Vargas was determined to find an answer for Brazil's oil question. A postwar nationalist campaign (1948-49), “O Petróleo é Nosso!” (Petroleum is ours!”), had put that issue in the center of Brazil's policymaking agenda, leading Vargas to include the state monopoly in the field of petroleum in his political platform of the 1950 election. That campaign was a reaction to an attempt by Dutra's administration (1946-1950) to loosen nationalist oil control, a move that was perceived as a threat to Brazil's industrialization (SMITH, 1976, p. 163). With it, the security arguments against majors had gained traction in military ranks. Drawing on General Horta's views, most of the officer corps were convinced to "drop its brief flirtation with economic liberalism with respect to oil”. (WIRTH, 1985, p. 134-135).

In order to encounter a viable solution for the oil question, Vargas setup the President's Economic Assessorship, composed, among others, by Rômulo de Almeida and Jesus Soares Pereira (CANO, 2015, p. 444). One of its most important tasks was to formulate a proposal to settle Brazil's oil question. As Jaguaribe explains, although the Assessorship lacked an administrative machinery which had been made available for the Joint Brazil-United States Economic Development Commission, it produced "a no less far-reaching program for the country's economic development" (JAGUARIBE, 1968, p. 147). Vargas submitted the "petroleum plan" (JAGUARIBE, 1968, p. 147) the Assessorship had produced to Congress in 1951. It was considered a moderate proposal, for it provided for a 51 percent government-owned holding company, and for oil development and refining in which private capital could have a large role in subsidiaries and associated enterprises (RANDALL, 1993, p. 9).

A debate that was both public and political, in congress, ensued after Vargas' proposal. On one hand, "entreguistas" claimed that Brazil would not develop its petroleum industry without foreign capitals. Some, like 
Odilon Braga, attempted to convince nationalists that without political support from the United States for the oil matter, Brazil would not be able to control the IOCs' advances and would not be able to resist "abuse (...) of an imperialist character" (COHN, 1968: 116). In the second half of 1951, Standard Oil itself advised the President (VICTOR, 1970, p. 297) that:

"for the industrialization of oil in Brazil to be successfully accomplished, there is a need for a climate that favors competition and free initiative. (...) This (...) [law project currently under discussion] (...) [rules out] the participation of foreign capital in this industry and [the establishment] of a favorable [business] climate."

By his turn, the liberal economist Otavio Bulhões (1952), discussed the pertinence of setting up barriers for Foreign Direct Investment (FDI) in the petroleum industry, which he believed were a form of prejudice against foreign capitalist. He also argued that FDI in that industry could enhance the country's overall welfare. Similarly, Juarez Távora contended that it was preferable to develop the oil industry with the aid of foreign capital and to gradually control and nationalize it. He believed that foreign firms would do a better job of exploiting oil and that the discovery of cheap and abundant oil by foreign companies would benefit the economy and compensate for the remittance abroad of income earned by foreign firms (TAVORA, 1955).

In fact, Vargas himself did not rule out the participation of foreign capital in the oil industry. In that context, Rômulo de Almeida defended the participation of foreign capital in the oil business in a congress hearing:

\footnotetext{
"In the project, what is intended, obeying to nationalist principles, is not to give concessions to foreigners, but to allow Brazilian juridical persons, with the participation of some foreign elements, to become partners of a state organization that is under perfect control of the State. (...) In my view, the identification of the state monopoly with one hundred percent state organization is inadequate. What does state monopoly mean? The State, through any of the organizations it disposes of and manages, is the sole concessionaire of the industry, (VICTOR, 1970, p. 321).”
}

On the other side of the political debate stood those who believed that oil should be an activity exclusively carried out by the state, which had been defended by the "O Petroleo é Nosso!" campaigners. That campaign eventually succeeded in cohering the views of different factions from the nationalist coalition, and some that formerly were outside it. Even Oswaldo Aranha, who had been an "entreguista", claimed that "there is only one conclusion (...) To the State and only to the State belongs the role of exploiting this wealth" (COHN, 1968, p. 170). Similarly, a military, General 
Arthur Levy, had summarized the nationalist sentiment that eventually would lead to the formation of Petrobras (LEVY, 1962, p. 25): "Energy is the motor of development and it is the heart of the national organism and therefore should be Brazilian. (...) No one lives with a borrowed heart!!”. In a context of political pressures, Vargas also joined the nationalist camp.

After three years of heated debate, the legislation that was eventually approved was radical, establishing a state monopoly which comprised all activities related to oil, with the exception of the distribution of oil products, an activity that already had been conducted by private enterprise, subsidiaries of the large international corporations, since the early 20th century. Petrobras, which was founded in 1953 as a mixed-economy state company, was assigned by the law Number 2004, from October 3, 1953, the task of carrying out monopolistic activities in the realm of petroleum and gas Exploration \& Production and the refining of oil (DIAS LEITE, 2009, p. 11). Petrobras was designed "as a well-capitalized, financially independent company", which led imports of refined products to fall considerably in the 1950s (WIRTH, 1985, pp. 137-138). As noted by Villela (1962, pp. 112-3), in the first years of its operation, Petrobras and other state companies received massive subsidies from the Federal Government, to finance the company's investments. With this, those corporation's capital formation was considerably high. However, because nationalists feared foreign capital, the creation of subsidiaries was discouraged, which lead to a reduction of the resources that could have accelerated Petrobras' process of vertical integration (CARVALHO, 1975, p. 17). Nonetheless, from the mid-1950s onwards, of all state enterprises controlled by the state, Petrobras was by far the most important, as it "gave the state a powerful lever with which to shape and direct the process of accumulation” (EVANS, 1979, pp. 91-2).

\section{AN INTELLECTUAL DEBATE}

Some years after a solution to the oil question in Brazil had been found, a debate about the pertinence of that solution continued to occur. One of the mains reasons for this was that, in the first years of its operation, Petrobras' exploratory results were disappointing. Petrobras targeted producing a daily output of 100,000 barrels of crude oil and refining 308,000 barrels per day in 1960 (JAGUARIBE, 1968, p. 154-5). By that year, it managed to increase its production to 75,000 barrels per day $(75,5$ percent of the target) and to expand to 218,600 barrels per day its refining capacity ( 71 percent of target) (ibid). In the context of poor exploratory results, the publication of Walter Link's report, who concluded that the existence of large oil reserves 
on Brazilian territory was improbable (PHILIP, 1982, p. 370), led to a momentary loss of direction, and it took some years before new directives could be established as to continue exploration on land (DIAS LEITE, 2009, p. 13). In that vein, the decision about whether foreign investment should be permitted to find for oil in Brazil was not entirely closed in the late 1950s, even though Juscelino Kubitschek (1956-1961) eventually discovered that it was valuable to assert his commitment to nationalism. In parallel, the US government continued its diplomatic pressures to allow foreign companies to explore oil in Brazil, such that the matter continue to be discussed in the Brazilian policymaking circle (PHILIP, 1982, p. 371-2).

The pertinency of Petrobras' exploration monopoly was also debated by Brasil's intellectuals also debated the pertinency of Petrobras'exploration monopoly. The liberal economist Roberto Campos, for instance, attacks the state monopoly in the petroleum industry and pleads for the liberalization of the 1953 Petroleum law in a conference during the 1950s, that was later republished in Campos (1964). In this work, Campos is concerned with the exchange rate crisis Brazil was then facing, and he believed that the attraction of foreign investments to the domestic petroleum industry could lead to a "radical and sudden elimination of our current balance of payments problems" (CAMPOS, 1964, p. 125). Campos also warned that Petrobras' decision to construct refineries and oil tankers was a dubious blessing for the country. In his view, although this could permit to save foreign currency in the long run, the incentive that this decision would give to industrialization would create more demand for foreign exchange in the short term, making the pressing balance of payments problem even worse.

Although Jaguaribe's (1958) contribution to this debate was not the first one, he was the first who presented a more technical and intellectual rigorous interpretation of the settling of Brazil's oil question and its historical, economic and political importance. Moreover, due to its reception, it had probably the most far-reaching consequences, because it was the first one with a genuine developmentalist perspective, having attracted much attention from his peers.

In his book "Nationalism in Brazil Today" Helio Jaguaribe (1958) compared and juxtaposed in a rigorous analytical approach, in a stylized way, the two possible solutions that were available to solve Brazil's oil question. On one hand, he the presented the nationalist solution, which, in his words, aimed at "making Brazil a historical individuality, assuming the risks and paying the price of this decision" (JAGUARIBE, 1958, p.143). On the other stood the solution presented by the advocates of "a cosmopolitan thesis", whose preference laid in the "colonial situation" (IBID). In his comparison, 
Jaguaribe parts from the premise that in the petroleum industry - which requires the use of specialized technology, that is constantly progressing forward and that must compete for the international supply and demand of factors - foreign capital has an inherent advantage when the question is considered solely in terms of economic efficiency (JAGUARIBE, 1958, p. 143). However, the nationalist thesis also has its validity in this sector of the economy because development is "a global social process, not just an economic one" (IBID). Jaguaribe argued that after systematic confrontation, both sides would tend to mutually neutralize each other. He thus argued that an unambiguous decision in favor of one them based on a purely rational analysis was difficult to achieve (COHN, p. 181). Jaguaribe thus contends that:

\begin{abstract}
"By proposing to consolidate the nation as its ultimate political goal, the community is confronted with the choice of sectors or activities in which it will most radically engage itself in its purpose of self-determination. (...) What is at issue is the assumption of one's own freedom, of creating the nation as the center of its own decisions. (...) The choice of sectors or activities in which this struggle for the affirmation of freedom occurs is something that can be done with greater or lesser reasonableness. (...) In the Brazilian case, the chosen sector (...) must necessarily be economic because it is in this area that the greatest obstacles to our development lie. This was done by the Brazilian community, after a broad and democratic discussion in which all participated, and the sector elected by it to fight the struggle for its freedom was oil. (...) The petroleum sector was the chosen one partly for entirely rational reasons, partly because of a dramatic act of arbitrariness. (...)" (JAGUARIBE, 1958, pp. 145-146)
\end{abstract}

Whilst resolving this dilemma, the country had to face a trade-off. If on one hand, the state monopoly favors an increase in the country's economic independence, on the other, it implies the elimination of the most efficient form of allocating investments from the point of view of economic rationality (COHN, 1968, p. 181). Having chosen the nationalistic monopoly solution, Jaguaribe advised that Brazil would have to bear the costs of its economicpolitical freedom. This would require from the country an increase in its national savings and the acceptance of the participation of foreign capital in more advanced sectors of the economy (JAGUARIBE, 1958, pp. 146-7)

As Souza (2009, p. 163-4) explains, members of the ISEB had the habit of presenting their studies to the other members's criticism before publication. When this was done with the first part of Jaguaribe's book, it was considered "heretical" by the nationalist sectors, mostly because they interpreted that Jaguaribe was defending the participation of foreign capital in the economy (SOUZA, 2010, p. 163-4). At that time, the question of the Brazilian 
state oil monopoly was inseparably tied to the nationalist issue, which led some students, sectors of the press and public opinion even to believe that Hélio Jaguaribe was cooperating with Standard Oil (IBID). By then, even though foreign investment had an important role in Brazil's process of industrialization, there was a fierce controversy about how much foreign capital should be accepted (SANTORO, 2008, pp. 12-13). The publication of his 1958 treatise on the petroleum question and the state monopoly thus led to Jaguaribe's departure and from his more conservative colleagues from ISEB (CHILCOTE, 2014), even though he had been clearly misunderstood.

In the decades that followed, several of high-quality contributions and valuable contributions - by political scientists, economists, and sociologists - sought to analyze both the mechanism that led to the settling of Brazil's oil question in 1953 and its historical, political and economic significance. Some of them were clearly inspired by Jaguaribe's contribution or attempted a response to him.

One such contribution was given by the structuralist economist Celso Furtado, who, like Jaguaribe, also identifies an acute conflict between two rivaling ideological groups for the case of oil. He identifies one line of thought that was committed to "the old export economy" (FURTADO, 1961 , p. 215), for which the domestic scarcity of resources was a reason not to channel scarce resources into an uncertain sector such as petroleum, were foreign capital was abundantly available. Also, like Jaguaribe, Furtado argues that the developmental strand does not handle the petroleum question in strictly economic terms. That strand was concerned with the defense "of the newly acquired dominance of its decision-making center" and was wary that the international petroleum companies' interests would be difficult to cohere with the ones from the nation. (FURTADO, 1961, p. 215). For Furtado, the synchrony between developmental interests and decisions was fundamental to overcome the phase when Brazil was a reflex economy, thus requiring an individualization of the country's economic system. Furtado hence regards the state as the economy's main decision-making center and attributes it with the task of coordinating the process of development.

Sylvio Monteiro, an economist who was a member of ISEB during its second and explicitly more radical phase - that lasted from 1960 to 1964 - (BRINGEL, 2018), also deals with the issue of petroleum in his 1963 "How does Yankee imperialism work?" (MONTEIRO, 1963). Bringel (2018) suggests that this book is a response to Jaguaribe (1958), even though the author does not cite him directly. In Monteiro's view, 'yankee imperialism' was to blame for the lack of oil exploitation in the country as it has succeeded "in preventing any oil exploration and processing initiative 
from being carried out in our country, thereby maintaining it as a market for its products and at the same time reserving for itself" (MONTEIRO, 1963, p. 109). Furthermore, for Monteiro oil majors never demonstrated much interest in exploring oil or investing in the refining business in Brazil. (IBID). In his view, then, Petrobras' foundation would be a bold answer to the claims of US imperialism, and would also represent "a victory of the Brazilian people for its economic emancipation” (IBID, pp.110, 113). Nevertheless, in Monteiro's view Brazil's oil question had not been settled yet, because the country's state oil monopoly would still be under the siege of its internal and external enemies. Monteiro highlighted as a particularly worrisome threat "the insemination, within the key organs of the state, of a pessimistic mentality of discouragement” (IBID, p. 113) regarding Petrobras' prospects of finding oil in the country's sedimentary basins. As the country would be "facing a great struggle for the conquest of Brazilian oil", Monteiro calls upon "our people in general, the workers, the students and all the other workers to unite" (IBID, p. 122).

With a much more moderate tone than Monteiro, the engineer and economist Antonio Dias Leite (DIAS LEITE, 1966) welcomed the existence of public enterprises such as Petrobras in what he called the country's "nucleus of economic expansion" (SINGER, 1976, p. 158). For the author, activities belonging to that core "should have their expansion accelerated as to avoid them becoming an obstacle to the overall development of the country" (DIAS LEITE, 1966, p. 36). Dias Leite believed that "the success or failure to meet the accelerated expansion goal of these industries has largely defined the country's overall development pace” (IBID). As Singer explains, Leite defends the "primacy of national capital vis-à-vis multinational companies and required the State to play an active role in the promotion of growth" (SINGER, 1976, p. 158). In the realm of the petroleum industry, which he regarded as paramount for the achievement of economic development, Dias Leite highlighted the importance of capital accumulation and of investments in exploration and development for the overall performance of the economy. Dias Leite, however, did not rule the participation of private national and private foreign capitals as sources of funding for the expansion of the petroleum industry. What regards the possible inefficiency of public enterprises such as Petrobras, Dias Leite contended that it could be minimized through a targeted program to achieve efficiency, be it through training programs or through the establishment of a system that incentivized workers' participation in the company's results, "conditioned to the improvement of sectoral and global efficiency." (DIAS LEITE, 1966, p. 53). 
Some years later the sociologist Gabriel Cohn also presented his contribution to the oil question debate (COHN, 1968). While emphatically criticizing Jaguaribe's approach, he proposes an explanation for the process leading to Petrobras' foundation, which he calls the Dynamics of the situation. According to that interpretation, the outcome of the process, namely the petroleum policy of 1953, was not the result of some carefully architected plan or the outcome of a Socratic dialogue between rivalling conceptions that could be rationally confronted, as he interpreted that Jaguaribe had argued before. In Cohn's view, the decision to create Petrobras was not "derived from the crystallization of a collective will." (COHN, 1968, p. 182). For him, the oil policy in the form that it emerged in 1953 "was imposed as a requirement of a material order" on whose definition hinged the very continuity of the Brazilian developmental process (IBID, p. 183). Cohn believes that, in general, no social group had had a decisive influence on the institution of the state oil monopoly in Brazil, as there was "a complex interaction between [interest] groups, (....) prompted and stimulated by pressing problems to sustain the global process of change that was taking place at all levels of national society" (IBID). For him, under a different set of circumstances another solution could have been found, as was the case in other Latin American countries. Hence, it was the "dynamics of the situation [that had] led to this [particular] decision, and not another one” (IBID). For Cohn, however, the dynamics of the situation could be distinguished from mere chance:

"this constellation of options was neither causal nor unlimited; on the contrary, it was limited and structured. Given the greater problem of the oil policy, its solution was imposed. (...) In these historical conditions, a certain number of options, limited in function of the social groups in presence, presented itself; (...). (..) What is sought to show, then, is the progressive narrowing of this field of decision-making possibilities, by virtue of the successive redefinition of its historical determinants, until the final solution adopted is reached (...)" (IBID, pp. 185-6)"

Nonetheless, Cohn particularizes a specific force that led to the solution adopted, which was the agency, in critical junctures, "of influential agents, capable of articulating the various aspects of the problem as they presented themselves at a given moment" (IBID). For Cohn, "in 1938, this synthesis was made by the military - under the leadership of Horta Barbosa; in 195153, by the parliamentary opposition, which included representatives of the Petroleum Campaign and the UDN” (IBID). 
In quite an opposite direction, the liberal economist Eugenio Gudin attacked the nationalist petroleum policy in a series of articles written in the mid-1960s, which were republished in 1969 (GUDIN, 1969). For instance, he criticized the import substitution industrialization (ISI) type of policy that had led to Petrobras' creation: "it is not possible to explain to people that industrialization was done to make goods and products not cheaper, but more expensive. Industry is not intended to enrich the industrialists but to enrich the nation" (GUDIN, 1969, p. 413). The author, who believed that the cost paid by the Brazilian people of financing Petrobras was too high, defended that foreign investments in that field should not be ruled out, as foreign capital and its technology had made possible the construction of Brazil's first large hydroelectric plants, that eventually were owned by Brazilian state companies. He also attacks Brazil's absurd "nationalistic complex of some of our ruling classes", which he classifies as being "xenophobic" (GUDIN, 1969, p. 428).

By his turn, the sociologist Octaviani Ianni (1971, pp. 127-8) argues that Petrobras' creation was a critical milestone in the creation of Brazil's state apparatus. According to the author, all the studies and debates carried out within the executive branch's sphere to find a solution for the petroleum question attempted to attend to the demands and interests of local and foreign capitalists, the military, economists, and politicians, in the political context of a democratic regime. Nonetheless, these actors had a preoccupation in achieving a compromise between that was necessary in economic, political, and technical terms, and that what was possible. Thus, Petrobras's foundation was a revelation of the executive's style of action and thinking, one in which consensus-building between the interests at play was permanently sought for. This thinking style underlies the creation, perfection, and development of an efficient government bureaucracy and state technostructure. Although Petrobras' initial technostructure was poorly developed and lacked structure, this was an essential experience in improving and increasing the Brazilian State's size. Thus, Petrobras' success created increasing returns for the policy traction of a national-developmental economic ideology that favored making even more stringent policy experiments with state-led industrialization.

Some years later, the liberal economist Campos would return to the oil question in his notorious work on the Brazilian developmental model of the military dictatorship, which he co-authored with Mario Henrique Simonsen (CAMPOS \& SIMONSEN, 1974). Campos was an ardent defender of Petrobras' investments abroad - particularly in Bolivia (Campos, 1963 and one of the main articulators of risk contracts in his role as Brazilian ambassador to the United Kingdom (see KUCINSKY, 1977, p. 58). In this 
work, Campos would argue that one of the most pressing "controversies" of the time - the nationalistic question - had been solved, in the case of petroleum, as Petrobras, in the aftermath of the "1964 Revolution, [was now] guided by industrial and pragmatic criteria, without political and ideological concerns, which, at different times in the past, have disrupted the company's efficiency" (CAMPOS \& SIMONSEN, 1974, p. 74). As proofs of this pragmatist turn, Campos identifies two openings to the private sector - one "oriented towards associations with foreign companies to explore oil abroad and within the country" and Petrobras' decision to take "a minority stake in petrochemical companies, in association with national and foreign firms" (IBID). Campos, who in the 1950s had participated in the Joint Brazil - United States Technical Commission and was aware that the take-off of Brazil's economic development had to be carefully planned by the state (which included the foundation of state companies in the realm of energy such as Petrobras), however disfavored the monopolistic solution in the realm of petroleum and gas exploration and production, as he was also oriented by a very pragmatist stance. Thus, if Campos at the very minimum tolerated Petrobras' creation for its potential role as remover of growth strangling points - albeit in association with foreign companies -, he envisioned its future role much more as a modern and efficient enterprise than as a burocratized state capitalist venture.

The political scientist Getúlio Carvalho, by his turn, interprets the state's pioneering activity in the petroleum industry as "the creative response to the Brazilian oil crisis" (CARVALHO, 1977, p. 92), in analogy to Schumpeter's concept of creative destruction (see SCHUMPETER, 1912). Whereas Schumpeter relates the rise of capitalism to the heroic agency of individual entrepreneurs, Carvalho argues that it was the state, and not Brazil's capitalist class, that took the pioneering initiative to kickstart the impressive ascent of Brazil's petroleum industry. Brazilian capitalists, Carvalho argues, "were happy to receive benefits from the government, such as political support, tax exemptions, and tariff protection (...) but refused to see any merit in the government's initiative", even though they themselves clearly lacked the interest in performing the heavy investments that the petroleum industry required (IBID). For Carvalho, then, the hostility faced by Petrobras in its initial stage of institutionalization can be explained in the light of a lack of a consensus about what should be the role of the state in the economy (IBID). According to the author, the opposition to Petrobras was mostly of an ideological nature, because the creation of Petrobras was not part of a socialist program of any kind, as it solely aimed at resolving a very specific problem, which was the lack of both foreign and private domestic capitals to build an 
industry with the size required by Brazil's then booming industrialization process (IBID, p. 93).

Some years later, the sociologist Luciano Martins (1985) identifies in Petrobras foundation an ideology of state intervention. As he describes it, "statism, nationalism, or developmentalism (...) often appeared as confused as interchangeable concepts, to the extent that they were perceived as instrumental to a nation's development project, served to politically justify the existence of state enterprise and the role played by its administrators" (MARTINS, 1985, pp. 59-60). According to the author's interpretation, the state's business action did not arise accidentally, as if it were disconnected from a well-defined political project, but rather after a long political debate. For Martins, that debate gave Petrobras the political legitimacy it required, as the state company's initial success depended on "an allocation of resources, based on forced savings, which had to be politically justified, given the system of representation of interests (IBID, p. 60).

Another author, the political scientist and economist Carmen Alveal (1994, p. 73) shows that different political and economic initial conditions favored a faster solution for Brazil's oil question, where "the decisive aspect that favored the sharpness and consequent political victory of the state option in the case of petroleum refers to the lack of any corporate structure of a certain relevance, public or private, national or foreign, implanted in the activities that constituted Petrobras' monopoly". In contrast, Eletrobras was founded in a context of an already existing institutional framework and of a consolidated sectorial productive structure, with the felt presence of foreign companies in the classical activities of the electricity industry (generation, transmission and distribution). Alveal thus contends that the same determination to give a bold solution to the petroleum question was not observed in the electricity industry, mainly due to a coexistence pact with foreign capital that established a division of labor between energyproducing and distribution activities in the electricity sector, permitting an accommodation between private and public interests in that industry (ALVEAL, 1994, p. 74). In the petroleum industry, these conditions were not present, paving the way for the nationalistic solution.

A final interpretation for Petrobras' creation worth mentioning here was presented by the engineer Joao Lizardo de Araujo and by the economist Adilson de Oliveira. The authors contend that (ARAUJO \& OLIVEIRA, 2004, p. 24-25) Brazil's process of industrialization and the ensuing development of a continental roads network faced the country with a considerable challenge, as the growth of oil imports would tend to press the country's balance of payments, thus tending to limit economic growth. This 
required the construction of an efficient domestic oil industry, with the statist solution imposing itself as the best solutionto organize the nascent industry. The authors argue that Petrobras' creation led to a rationalization of efforts, the programming of exploration efforts, and a reduction of geological risk (IBID). After the monopoly was established and there was guarantee that competing companies would exploit no other basin, Petrobras could start to program its risks, "starting with the basins with greater prospects, and, progressively, exploring the others (IBID)." Hence, in the author's view "the facts converged to the creation of Petrobras, [as] only the state monopoly was capable of reaching more rapidly the optimum scales of production"(IBID).

\section{JAGUARIBE AND HIS LATER CONTRIBUTIONS TO THE OIL QUESTION}

After his first groundbreaking to the subject Jaguaribe would return to the oil question in other occasions (JAGUARIBE, 1974; 1977; 1989). This last section reviews them while locating them in their historical context. It is argued that Jaguaribe's relatively pragmatic stance in matters of economic development was well-equipped to deliver a valuable and timely diagnosis of the challenges that Brazil's petroleum industry faced over the decades.

The crisis of the miracle and the oil question

In 1974, when the economic model of the military dictatorship was to a large extent established, Jaguaribe diagnosticated the main economic problems that Brazil was still facing in what he believed was still a stage of dependent development:

"[a style of] economic development through the predominant participation of large foreign companies in the strategic sectors of the manufacturing and capital goods industries (...) necessarily leads to the perpetuation and worsening of dependency. The simplest and most commonly used technological processes are quickly mastered by national companies. The most sophisticated and stateof-the-art technological processes are increasingly under foreign control. For these and other reasons, foreign companies are developing at a level and pace incomparably higher than domestic ones (...). National companies are relegated to small and medium-sized businesses or to traditional, slow-growing, low-tech sectors." (JAGUARIBE, 1974, pp. 70-71).

In that context, Jaguaribe (1974) underscores that only public national companies such as Petrobras were progressing forward. Nevertheless, for him it would be an illusion to believe that their growth would compensate for the "hypertrophy of foreign companies in the manufacturing and capital 
goods sectors" (JAGUARIBE, 1974, p. 71), or that having set up those large public national companies would be enough to control the country's productive system. Although Petrobras and other state companies provided basic inputs on which foreign companies depended, for them far more important resources were technology and appropriate state regulations, on which they already could count on. In that vein, Brazil's public-controlled corporations would be in an unfavorable situation because "the goods and services offered by the Brazilian public companies to the industrial park of the country, under the control of multinationals, are supplied at extremely low prices, close to cost, [sometimes even] subsidized by the state (...) [as] is currently happening with oil and its derivatives" (IBID). Even though this was a bleak scenario, Jaguaribe did not defend the "suppression of multinationals" as for him it would be "feasible, within varying limits, to discipline such companies as to better adjust them to the national interest" (IBID). Furthermore, the author believed that peripheral countries could reinforce their domestic power through the implementation of domestic consortia or common markets. For Jaguaribe, a far more crucial step towards the overcoming of dependence would be "the creation of an alternative technological and organizational capacity” (IBID). He thus contended that:

\begin{abstract}
"in order to acquire conditions for proper technological and organizational development, it is necessary, on the one hand, to have a critical mass, in terms of human and material resources, which implies, again, for the peripheral countries, an effort of consortium and coordination. On the other hand, if there is a critical mass, it is essential to stimulate the development of science and technology” (JAGUARIBE, 1974, p. 74).
\end{abstract}

In fact, like Jaguaribe probably would have favored, from the second half of the 1970s onwards, Petrobras started to accelerate the development of a domestic petroleum goods and services industry and to step up its own and this industry's technological capacities. Faced by mounting balance of payment pressures after the first oil shock had considerably increased the country's oil bill, Petrobras started to tackle with great seriousness its plan to raise domestic oil production through increased offshore exploration. As early as in the late 1970s the "calculus of public investment in Petrobras [was altered], (...) making the cost of technological innovation to explore the continental shelf financially viable in comparison to the import cost" (BROOKS \& CURTZ, 2016, p. 44). This eventually would result in the development and utilization of growingly sophisticated technology to exploits Brazil's Deep water oil reservoirs (IBID, pp. 43-4). By then, "Petrobras was forced to build a large network of national suppliers that could contribute to the development of its activities" (ZAMITH, 2001, p. 
88). It started to use a nationalization system, thus replacing the import of priority products and seeking alternative suppliers. In that arrangement, Petrobras had much autonomy in decisions related both to technological and industrial aspects. As Randall reports, "if in 1957 Petrobras imported $80 \%$ of its equipment and spare parts; by 1979 , this was reduced to $20 \%$." (RANDALL, 1993, p. 88). By the mid-1980s, Brazil was thus able to reduce its imports of capital goods to one fifth, being able to save around $\$ 2.2$ billion through its import substitution policy in 1984 (IBID). In the late 1980s, as a result of the incentives given to Brazilian manufacturers and due to a shortage of foreign exchange, domestic manufacturers were able to supply more than $90 \%$ of Petrobras' necessities. Furthermore, Petrobras' insistence on quality led to improvements in the capital goods industry:

"As a result of the sophistication of Petrobras' requirement, its suppliers were more likely to have R\&D and to purchase technology than the rest of the metal mechanical industry, which did not have to meet such stringent standards. New products were developed by $90.6 \%$ of Petrobras' suppliers, compared to $77.8 \%$ of firms not supplying Petrobras. Petrobras' suppliers generally used more modern methods and had fewer losses due to poor quality of raw materials, machines and equipment, and inadequate workers than firms not supplying Petrobras." (RANDALL, 1993, p. 235-6)".

As was seen, Jaguaribe also regarded as a possible solution to overcome the phase of dependent development the establishing of consortia with multinational companies, through the intelligent harnessing of their more abundant technological and financial resources. In that vein, Evans contends that the development of Brazil's petrochemical industry during the 1970 s and 1980s was "an archetypal example of alliance-building" (EVANS, 1979, p. 227). In 1973 Petrbras, through its subsidiary Petroquisa entered into the petrochemical business after a domestic private group - The Capuava Group - had pionereed this industri's large scale-development some years before. Thus it assumed a crucial position in Brazil's petrochemical usiness when it was clear that group lacked financial strength. Evans (1979) thus sees the "tripod" formed between Petrobras, multinationals and private domestic partners in the petrochemical business as a novel institutional arrangement in Brazil's industrial structure, and as proof that the state was attempting to attenuate the economy's foreign dependence through novel solutions.

The 1973 oil shock and Brazil's oil question

In a 1977 paper (JAGUARIBE, 1977), Jaguaribe discussed the economic and socio-political implications of the 1973 oil shock. According to his analysis, the oil shock could lead either to a third World War, to the establishment of a 
global regime under the shared direction of the superpowers, or to the radical restructuration of the flow of economic transactions and of the international system (JAGUARIBE, 1977, p. 658). For the author, the third possibility would be the most likely to happen. He contended that the oil shock had occurred a divide between the industrialized and underdeveloped countries where the former would export their modern goods and services at very high prices to the latter and import from them goods and primary services at much lower fares. In that context, the scock had dramatically changed exchange relations, as with the quadrupling of oil prices, major oil exporters would now be able to capture a much larger share of the global value-added. Jaguaribe was confident that the world trade solution for the oil crisis could be negotiated between its main protagonists, both major oil producers, the United States and the soviet bloc. For the author, the oil crisis could "open (...) up an exceptional opportunity for underdeveloped countries to make a decisive contribution (...) in the structuring of a new democratic and openworld system, with the use and support of the mechanisms of the United Nations" (JAGUARIBE, 1977, p. 664). He also believed that "countries that are in an advanced stage of industrialization, such as Brazil and Mexico" were capable to contribute to the establishment of "a new, democratic and open world system" (IBID).

Indeed, when Brazil was hit by the first oil shock of 1973, it was already a consolidated industrial economy, with an industry that operated almost at full capacity (DORIA, 1976, p. 58). In the context of strong industrial growth, Brazil also had managed to increase its production's technological content. For instance, Bonelli (1976) - who employed a growth-accounting approach and data for the period 1959-1970 for twenty-one manufacturing industries - found that 22 percent of the total output growth of all those industries was not explainable either by growth in the capital stock or increases of the labor force. The author interpreted the residual as representative of technological change, and for some industries - such as machinery, electrical equipment, and pharmaceutical - those residuals were especially high.

When the oil crisis effectively hit Brazil, its immediate impact was an increase oil bill. Whereas Petrobras could import a barrel of oil (CIF) for an average US\$2,07 in 1969, in 1974 it had to disburse US\$12,50 for the same amount of oil (CARVALHO, 1977, p. 185). Thus, a growing oil bill was causing worryingly growing balance of payments problems. By then, Brazil's frenetic pace of growth of the early 1970s had slowed down, while inflationary pressures had restarted. According to Boa Nova (1985, p. 131), those were early signs of the recession in which the country would land in the 1980s. Thus, the military administration thus realized that it would have to 
do a major effort of economic expansion in order to resolve Brazil's external constraints. The diagnostic was that Brazil required a more aggressive strategy to overcome its external constraints, requiring it to improve its export base. In that context, the II PND, launched in 1974, emphasized the further substitution of capital goods imports and basic inputs such as basic inputs such as petroleum. According to Frieden (1991, p. 119-123):

\begin{abstract}
“(...) The government made massive investments in activities that provide basic inputs to modern industry. The investment program was primarily carried out by parastatal enterprises, often in the form of such imposing "big projects" as the Itaipu, (...). Public enterprises' share of gross fixed capital formation went from $20 \%$ in 1970 to $23 \%$ in 1974 and $29 \%$ in 1979 (....) [Another] major feature of the 'big projects' period was a systematic network of subsidies and incentives to more advanced portions of private industry. (...) The investment programs of the 1970 s would have virtually unthinkable without the availability of foreign finance. (...)"
\end{abstract}

Heavily relying on abundant external finance, the II PND thus "effectively ignored the constraints imposed on the economy by the emergence of domestic capacity limitations and the quadrupling of oil prices in 1973." (BACHA, 1980, p. 22). As Dias and Quaglino explain, from 1974 onwards external lending started to sum an ever-larger share of Petrobras' budget (DIAS \& QUAGLINO, 1993). In particular, both the energy sector as a whole and the petroleum sector were thus important culprits of the debt crisis of the 1980s.

\title{
The crisis of the Brazilian state and the oil question
}

Jaguaribe would return to Brazil's oil question by the end of the 1980s when he discussed the crisis of the Brazilian state, which he saw as a direct outcome of the economic policies implemented during the 1970s. Jaguaribe argued that the Brazilian state's crisis was related to "an increasing structural and functional deterioration, (..) a loss of rationality, transparency, functionality, efficiency, and responsibility" (JAGUARIBE, 1989, p.11). At the root of the state's crisis he also identified"a dysfunctional tendency to state hypertrophy (...) an immanent propensity on the part of all bureaucratic power, if not restrained by other forces, to expand (...) its own power" (IBID). Thus, in his view, even "the most successful public companies (such as Petrobras) acted as holdings of a private conglomerate, and multiplied the creation of subsidiaries, justifying them as vertical or horizontal integrations producing economies of scale"(IBID, p. 53). 
This growth tendencies, according to Jaguaribe, had become worse during Figueiredo's (1979-1985) and Sarney's (1985-1990) administrations. The state insolvency problem would be characterized by "a structural imbalance between revenue and public dispatch" (IBID, p. 66). At the federal level, the financial crisis mainly refers to a "relative decline of gross taxation and, particularly, of net taxation” (IBID). He also related it to a policy of controlled prices by the government, which it implemented due to the existence of an "important multiplier effect that the price of infrastructural inputs and services has on the final composition of prices" (IBID). In that sense, "the federal government, in its continued (and misdirected) attempts to control inflation, has been systematically imposing on public companies operating in the infrastructure and basic sectors, prices below their cost level, also harming their competitiveness".(ibid). This price gap was a difficulty that was also faced by the oil sector, both due to depressed fuel prices to a policy of subsidizing Brazil's ethanol production. This pricing policy would not only lead to a deterioration of the quality of public services, but also to a decreased morale of the companies, and, ultimately, would force the Union into conceding more and more subsidies, eventually eroding its net revenue. (IBID, p. 65).

For Jaguaribe, the key to solving the country's structural economic problems were substantial investments in social policy, infrastructure, energy, and scientific-technological development (IBID, p. 19). Nevertheless, within an inflationary context also characterized by high public deficits and elevated interest rates, these disbursements would be practically unviable and would tend to trigger a potentially out of control explosive hyperinflation. In that vein, Jaguaribe believes that there would be no other remedy than setting "in motion a drastic anti-inflationary policy" and to face "its inescapable recessive effects", which he regarded as an "undeniable prerequisite for a major development and reform program" (IBID).

Another problem that Jaguaribe related to the state's crisis was what he called "notarial corporatism", which he related to a tendency by public companies' unions - such as Petrobras' and Eletrobras - to make unfair and excessive demands. Because those companies operated under monopoly or oligopolistic conditions and provided essential services to the population, those unions' excessive demands would potentially be felt by the entire population (IBID, p. 22). As a side effect, consumers and society would blame the state - and not unions - for the abused suffered and become susceptible to embracing radical pro-market policies.

For Jaguaribe, thus, the solution to control "notarial corporatism" and for the crisis of the state in general was "a prudent but firm policy of opening 
inwards and outwards" (IBID). The process of opening up the economy inwards would entail "eliminating privileges and notary immunities, through the legal regulation of these services, the establishment of public controls that supervise, with the necessary powers, their convenient rendering and penalizing abuses” (IBID). By its turn, the process of outwards opening of the economy would require the flexibilization of state monopolies, such as petroleum, to investments by private investors. At this point Jaguaribe highlights that it was important that at a certain stage of the country's economic history sectors that are key to economic development were subjected to public control, as was the case of oil \& gas petroleum from the 1950 s to the 1970 s. Moreover, in his view from 1940 to the 1960 s the state had lacked regulatory and supervisory capacities, which justified certain reservations concerning foreign capital, "as well as the granting of public monopolies for the exploitation of certain sectors, as in the case of Petrobras" (IBID p. 102). However, in the context of the crisis of the 1980s, Jaguaribe advocates for a more modern and mature discussion about the importance of foreign capital in the Brazilian economy. Much of these reservations regarding foreign capitals, Jaguaribe contends, "have become obsolete (...) as Brazil today has ample capacity to regulate and supervise its economy" and because "the world (...) has become extremely integrated, economically and technologically, being generally counterproductive to isolation positions" (IBID).

Nonetheless, Jaguaribe was not a radical adept of the free market solution, as he acknowledges that profitable companies, such as Petrobras, should not be privatized, although they should be removed from their former obsolete monopolistic condition. In conclusion, Jaguaribe calls upon "an intelligent policy to attract foreign capital, which will increase our general investment capacity and give us all the possible advantages of technological and managerial development." In that context, "foreign investment, under conditions that are appropriate to the national interest, constitute, in addition to a development factor, decisive support for a policy of substantial external debt relief" (IBID, p. 102).

Jaguaribe's diagnostic of the crisis of the state, and ultimately, of the factors that were retarding Brazil's economic recovery, was a very pragmatic one, especially what concerns the role of private capital and the importance of a relatively conservative fiscal consolidation path. He had the same pragmatic stance towards the oil question. As a matter of fact, some thirty years after the publication of "O Nacionalismo na atualidade brasileira” (JAGUARIBE, 1958) the author still believed that under certain circumstances foreign capitals could play an important role in the petroleum 
sector. With his analysis, Jaguaribe competently anticipated what was to come during the nineties, when Petrobras' monopoly was flexibilized (1995), and when a new regulatory framework was created for that sector in 1997, with the Petroleum Law. Nevertheless, as Jaguaribe recommended, Petrobras was never privatized, although in several occasions rounds of equity underwriting were undertaken. In industry, there is a relatively widespread view that the flexibilization of Petrobras' monopoly was, in fact, an important step for the discovery of the pre-salt layer. The finding of the pre-salt was probably Brazil's most important developmental event in the $21^{\text {st }}$ century, and it has created the hope that the country may develop itself on a more sustainable basis. Although there have been some important drawbacks in recent years, Petrobras is still an important developmental tool, as Jaguaribe probably would have recommended it.

\section{CONCLUSIONS}

The publication of Hélio Jaguaribe's 1958 book (JAGUARIBE, 1958) triggered considerable debate in Brazil's developmental circles. Due to his positions on Brazil's oil question, which were considered inadmissible by some of the nationalists, it caused a breach at ISEB, one of Brazil's most important economic and political think tanks, with Jaguaribe's resignation. In this article, it has been argued that his contribution did not intend to question the nation's choice of granting Petrobras's with an oil \& gas E\&P monopoly, but to frame that debate in a much more a pragmatist and realistic base. Jaguaribe had shown that if Brazil had sovereignly chosen the monopoly option, it would have to deal with its consequences, as Brazil's economic, financial and technological were clearly not unlimited. Having chosen that solution, it would not be possible for Brazil to rule out foreign investments in other sectors of the economy. Because the catching up strategy Brazil was pursuing was very accelerated, dangerous bottlenecks that could lead to balance of payments problems could only be avoided if Brazil supplemented its domestic savings with foreign capitals from MNCs.

Jaguaribe's ground breaking contribution to the oil question - from a genuinely developmentalist standpoint and with much more analytical and technical rigor than the countless more journalistic articles on the subject during the 1950s - was one of the very first ones of an important debate among economists, sociologists and political scientists on Brazil's oil question. Some of the authors were responding directly to him, such as Monteiro (1963) and Cohn (1968), while his contribution likly influenced others. Although Jaguaribe's contributions had analytical flaws, as shown 
by Cohn (1968) mainly what concerns the analysis of the mechanism that led to the solution of Brazil's oil question, its influence on this debate is undeniable.

In the decades that followed, Jaguaribe would return to the oil question other times, one in the context of the "Brazilian miracle's" mid-1970s crisis, one in the context of the oil shock, and another when Brazil was still facing the consequences of the 1980s debt crisis. Jaguaribe's realistic and pragmatist stance was highly perceivable, in all these contributions but he never abandoned his developmental convictions. Jaguaribe's views on the crisis of the state likely influenced Bresser-Pereira's initiatives to reform the state during the 1990s, which had consequences in the petroleum industry through the foundation of ANP in 1997. If Jaguaribe, on one hand, never ruled out the participation of MNCs in Brazil's economic life, he also made clear that for him an autonomous developmental policy focusing on the accumulation of human capital, human wellbeing, and technological capacities was the key to Brazil's economic success. Even when the winds of liberalization, privatization and deregulation started to reach Brazil, Jaguaribe acknowledged that Petrobras as a public company had an important role to play in the country's developmental plans.

Helio Jaguaribe's legacy in the realm of the study of Brazil's oil question still resonates today. Even though one and a half-decade of energy-based developmental plans have seemingly been dismissed, Jaguaribe's proposals are still timely. Brazil is no longer in the position to rule out foreign oil \& gas investments, but the key to Brazil's endeavor still lays in the accumulation of technological capacities and social expenditures, both to be financed with oil \& gas revenues. This is a critical juncture in which a liberal economic policymaking approach irresponsibly wants to use Brazil's petroleum windfall profits to reduce Brazil's short-term debt, in sharp discordance with the recommendations of an enormous resource-based economic growth literature (see for instance BARBIER, 2007). The rereading of Jaguaribe's works on the subject not only shows that this approach will probably result in a missed opportunity but also helps to find ways forward.

\section{References}

ALVEAL, E. D. C. Os desbravadores: a Petrobrás e a construção do Brasil industrial. Rio de Janeiro: Relume Dumará, 1994.

ARAÚJO, J. L.OLIVEIRA, A. Diálogos da energia: reflexões sobre a última década, 19942004. Rio de Janeiro: 7letras, 2005.
BACHA, E. L. Selected Issues in Post-1964 Brazilian Economic Growth. In.: TAYLOR; L. BACHA, E.L., CARDOSO, E. Models of growth and distribution in Brazil. New York: Oxford University Press, 1980, pp. 17-48. 
BARBIER, E. B. Natural resources and economic development. Cambridge: Cambridge University Press, 2007.

BOA NOVA, A. C. Energia e classes sociais no Brasil. São Paulo: Edições Loyola, 1985.

BONELLI, R. Tecnologia e crescimento industrial: a experiência brasileira nos anos 60 (No. 25). Rio de Janeiro: IPEA/INPES, 1976.

BRESSER-PEREIRA， L.C. Interpretações sobre o Brasil In: Loureiro, M. R. (1997). 50 anos de ciência econômica no Brasil (19461996). Petrópolis: Vozes, 1997. pp. 17-69.

BRINGEL, T. G. As críticas no "último" Iseb ao projeto nacional-desenvolvimentista de Hélio Jaguaribe. Revista Iniciativa Econômica, v. 4, n. 1, 2018.

BROOKS, S.M, KURTZ, M.J., Natural Resources and Economic Development in Brazil. In: Schneider, B.R. (ed.). New Order and Progress, Development and Democracy in Brazil. Oxford University Press, 2016.

BULHÕES, O. G. Economia e nacionalismo. Revista Brasileira de Economia, v. 6, n. 1, 1952, pp. 91-117.

CAMPOS, R. Economia, Planejamento e Nacionalismo. Rio de Janeiro: APEC editora, 1963.

CAMPOS, R.Ensaios de história econômica e sociologia. Rio de Janeiro: APEC editora, 1964.

CAMPOS, R., SIMONSEN, M. H. A nova economia brasileira. Rio de Janeiro: José Olympio Editora, 1974.

CANO, W. Crise e industrialização no Brasil entre 1929 e 1954: a reconstrução do Estado Nacional e a política nacional de desenvolvimento. Brazilian Journal of Political Economy, v. 35, n. 3, 2015, pp. 444-46o.

CARVALHO, G. Petrobrás: Do monopolio aos contratos de Risco. Rio de Janeiro: Editora Forense-Universitária, 1977.

CHILCOTE, R. H. Intellectuals and the search for national identity in twentieth-century Brazil. Cambridge: Cambridge University Press, 2014.
COHN, G. Petróleo e o Nacionalismo. São Paulo: DIFEL, 1968.

DIAS, J. L. D. M., QUAGLINO, M. A. A questão do petróleo no Brasil: uma história da Petrobrás. Rio de Janeiro: FGV, 1993.

DIAS LEITE, A. Caminhos do desenvolvimento. Rio de Janeiro: Zahar Editores, 1966.

DIAS LEITE, A. Energy in Brazil: towards a renewable energy dominated system. Abingdon: Routledge, 2009.

DORIA, P. R. Energia no Brasil e dilemas do desenvolvimento. Petropolis: Vozes, 1976.

EVANS, P. B. Dependent development: The alliance of multinational, state, and local capital in Brazil. Princeton: Princeton University Press, 1979.

FRIEDEN, J. A. Debt, development, and democracy: modern political economy and Latin America, 1965-1985. Princeton: Princeton University Press, 1991.

FURTADO, C. Desenvolvimento e subdesenvolvimento. Rio de Janeiro: Fundo de Cultura, 1961.

GUDIN, E. Para um Brasil melhor. Rio de Janeiro: APEC Editora, 1969.

JAGUARIBE, H. O nacionalismo na atualidade brasileira (Vol. 1). Rio de Janeiro: Ministério da Educação e Cultura, Instituto Superior de Estudos Brasileiros, 1958.

JAGUARIBE, H. Economic \& political development: a theoretical approach \& a Brazilian case study. Cambridge, MA.: Harvard University Press, 1968.

JAGUARIBE, H. Brasil, crise e alternativas. Rio de Janeiro: Zahar Editores, 1974.

JAGUARIBE, H. La crisis del petróleo y sus alternativas internacionales. El Trimestre Económico, v. 44(175), n.3, 1977, pp. 653-664.

JAGUARIBE, H. Alternativas do Brasil. Rio de Janeiro: J. Olympio Editora, 1989.

KUCINSKY, B. Petróleo: contratos de risco e dependência. Coord.: Bernardo Kucinsky) São Paulo: Brasiliense, 1977.

LEVY, A. Energia não se importa. Rio de Janeiro: Biblioteca do Exército, Ed., 1962 
MANTEGA, G. A economia política brasileira. Petrópolis: Vozes, 1991.

MARTINS, L. Estado capitalista e burocracia no Brasil pós-64 (Vol. 82). Rio de Janeiro: Paz e Terra, 1985.

MONTEIRO, S. Como atua o imperialismo ianque? (Vol. 12). Rio de Janeiro: Editora Civilização Brasileira, 1963.

PHILIP, G. Oil and politics in Latin America: nationalist movements and state companies (Vol. 40). Cambridge: Cambridge University Press, 1982.

RANDALL, L. The political economy of Brazilian oil. Westport: Greenwood, 1993.

SANTORO, M. A economia política do desenvolvimento: Roberto Campos e Celso Furtado. Cadernos de Sociologia e Política, (10), 2008.

SCHUMPETER, J. A. Theorie der wirtschaftlichen Entwicklung. Leipzig: Duncker \& Humblot, 1912.

SINGER, P. A crise do "milagre" (Vol. 2). Rio de Janeiro: Paz e Terra, 1976.
SMITH, P. S. Oil and politics in modern Brazil. Toronto: Macmillan of Canada, 1976.

SOUZA, E. R. O ISEB: A Intelligentsia Brasileira a serviço do nacional-desenvolvimentismo na década de 1950. Revista Tempo, Espaço e Linguagem, v. 1, n. 1, 2009, pp. 147-164. TAVORA,J.N.F, Petróleo para o Brasil. Rio de Janeiro: José Olympio, 1955.

VICTOR, M. A batalha do petróleo brasileiro (Vol. 72). Rio de Janeiro: Civilização Brasileira, 1970.

VILLELA, A. As Empresas do Governo Federal e sua Importância na Economia Nacional-1956/1960. Revista Brasileira de Economia, 16(1), 1962, pp. 97-113.

WIRTH, J. D. The oil business in Latin America: the early years. Washington, D.C.: Beard Books, 1985.

ZAMITH, R. A indústria para-petroleira nacional (Vol. 180). São Paulo: Annablume, 2001.

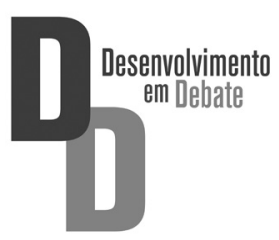




\section{Agradecimentos}

Desenvolvimento em Debate gostaria de agradecer aos pareceristas que contribuíram com a revista em 2020 , tornando possível o sistema de avaliação por pares adotado por este periódico. A qualidade dos textos depende do trabalho anônimo desses nomes:

\author{
Alejandra Facciuto (UBA) \\ Alex Mengel (UFRGS) \\ Aloísio Ruscheinsky (UNISINOS) \\ Amilton Moretto (UNILA) \\ Ana Célia Castro (UFRJ) \\ Andrea Ribeiro (UFF) \\ Andrés del Rio (UFF) \\ Antônio Márcio Buainain (UNICAMP) \\ Arnaldo Provasi Lanzara (UFF) \\ Atilio Roque González (Conacyt) \\ Biannca Castro (UFRRJ) \\ Carlos Eduardo Santos Pinho (UNISINOS) \\ Carlos Henrique Vieira Santana (INCT-PPED) \\ Cecilia Del Bono (UBA) \\ Charles Pesanha (UFRJ) \\ Claudia Bissagio Soares (UNILA) \\ Claudio Antônio Egler (UFRJ) \\ Diogo Ferreira da Rocha \\ Eduardo Rodrigues Gomes (UFF) \\ Estela Neves (UFRJ) \\ Florencia Antía (UDELAR) \\ Francisco Duarte (INCT-PPED) \\ Ignacio Godinho Delgado (UFJF) \\ José Miguel Busquets (UDELAR) \\ Leonardo Granato (UFRGS) \\ Liliana Acero (INCT-PPED)
}

\author{
Loreja Granja Hernández (ALACIP) \\ Lucimara Flávio Reis (UNILA) \\ Marcela Nogueira Ferrario (UNILA) \\ Marcial Suárez (UFF) \\ Marcus Ianoni (UFF) \\ Maria Alejandra Nicolás (UNILA) \\ Maria Antonieta Leopoldi (UFF) \\ Maria Luzia Brzezinsky (UNILA) \\ Maria Tereza Leopardi (UFRJ) \\ Marília Veríssimo Veronese (UNISINOS) \\ Moisés Balestro (UNB) \\ Nírvia Ravena (UFPa) \\ Pedro Staevie (UNILA) \\ Rafael Shoenmann (INCT-PPED) \\ Renata La Rovere (UFRJ) \\ Renata Peixoto (UNILA) \\ Renato Boschi (IESP-UERJ) \\ Rodrigo Gandra (UFRJ) \\ Rodrigo Medeiros da Silva (UNILA) \\ Silvia Lima de Aquino (UFRGS) \\ Silvia Zimmermann (UNILA) \\ Valdemar Wesz Junior (UNILA) \\ Wallace Moraes (UFRJ) \\ Ximena Simpson (UNSAM) \\ Yuri Kasahara (University of Oslo)
}





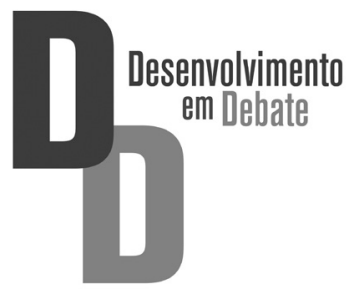

\section{POLITTICA EDITORIAL}

A equipe editorial da revista Desenvolvimento em Debate se compromete a manter elevada conduta ética durante todo o processo em relação à publicação e seus colaboradores; rigor com a qualidade dos artigos científicos a serem publicados; selecionar revisores capacitados e ecléticos com educação ética e respeito profissional aos autores e ser imparcial nos processos decisórios, procurando fazer críticas sempre construtivas e profissionais. Para tal fim, a revista adota o código de conduta do Conselho Nacional de Desenvolvimento Científico e Tecnológico (http://www.cnpq.br/web/ guest/diretrizes).

A revista publica artigos originais de pesquisa, ensaios e resenhas relacionados com a temática do desenvolvimento socioeconômico. Ênfase é dada a trabalhos que analizam o papel do Estado e das instituiçóes no desenvolvimento, políticas públicas setoriais e estratégias de desenvolvimento, o papel da geopolítica na dinâmica econômica e sustentabilidade ambiental, como também a pesquisas acerca de casos nacionais ou em perspectiva comparada, sobretudo de países da América Latina.

Os textos submetidos para publicação podem ser em português, espanhol ou inglês e devem ser inéditos. Ocasionalmente, por seu mérito acadêmico, a revista publica traduzóes de artigos originais em linguas que não sejam o português.

Pelo menos um dos autores deve ter a titulação mínima de mestre.

A revista adota o processo de avaliação por pareceristas anônimos. Os artigos passam por um processo de avaliação com três etapas. Na primeira, de caráter formal, avalia se o texto respeita as normas editoriais. $\mathrm{Na}$ segunda, decide se o artigo se adequa ou não ao escopo da Desenvolvimento em Debate. Em caso de ser negativo, comunica aos autores o motivo da rejeição. Em caso de ser positivo, o artigo é enviado a pareceristas externos. A publicação está condicionada à aprovação por parte de dois avaliadores externos à revista. 
O corpo editorial pode aceitar artigos para publicação, com ou sem recomendação de alterações. Nõ caso de serem necesárias alterações, a versão final do artigo deve ser enviada no prazo de um mês posterior ao envio da avaliação dos pareceristas externos.

\section{NORMAS PARA A SUBMISSÃO DE ARTIGOS}

- Os artigos devem ser submetidos pelo correio eletrônico da revista: revdesenvolvimentoemdebate@gmail.com.

- Os artigos submetidos devem ter entre 7,000 e 12,000 palavras (incluindo as notas de fim, resumos, bibliografia e legendas), em fonte Times New Roman, tamanho 12, com espaço 1,5 e parágrafo justificado.

- Os manuscritos devem incluir um resumo em português e em inglês, explicitando objetivos do artigo, metodologia epregado e as principais conclusóes. O resumo deve ter entre 100 e 150 palavras e deve ser acompanhado de entre 3 a 5 palavras-chave.

- Devem ser submetidos no mesmo processo dois arquivos. Um contendo os dados dos autores e outro com o manuscrito sem identificação de modo de evitar qualquer informação que revele a autoria do artigo.

- As notas de fim deverão ser evitadas ao máximo e, quando existirem, restringirem-se a conteúdo e estarem enumeradas automaticamente em algarismos arábicos em ordem crescente e listadas no final do texto.

- As citações diretas com mais de três linhas devem estar destacadas do texto, recuadas $4 \mathrm{~cm}$ à esquerda e com espaçamento simples entre linhas. O texto deverá ser digitado em Word For Windows e não deverá ter numeração de páginas.

- As figuras devem incluir um título auto-explicativo, na língua do texto, numerado em algarismo arábico, alinhado na margem esquerda e posicionado logo acima da figura. A fonte deve estar logo abaixo da figura. Aqui incluem-se, gráficos, fotografias (nítidas e com contraste), desenhos, etc.

- As tabelas dvem suplementar e não duplicar o texto, numeradas em algarismos arábicos. O título deve ser auto-explicativo, na língua do texto, alinhado na margem esquerda e posicionado acima da tabela. A fonte deve estar logo abaixo da tabela. 
As Referências Bibliográficas no texto devem ser citadas de forma corrida, segundo as normas da ABNT. Recomenda-se evitar citação de resumos simples, somente citando resumos expandidos de Congressos ou de outro evento científico de mesma natureza.

\section{LISTA DE REFERÊNCIAS}

Toda a literatura citada ou indicada no texto deverá ser listada em ordem alfabética. Artigos em preparação ou submetidos à avaliação não deverão ser incluídos nas referências. A formatação das referências deve seguir o padrão estabelecido pela Associação Brasileira de Normas Técnicas (ABNT) em "Regras Gerais de Apresentação" - NBR-6023, de agosto, 2002.

\section{Exemplos de referências}

Os exemplos a seguir não devem ser considerados como referências reais, pois alguns tiveram elementos adicionados a título de exemplificação.

\section{Livros}

SOBRENOME, Inicial nome. Título. Cidade da editora: Editora, Ano de publicação.

\section{Exemplo:}

REID, D. Sustainable development: an introductory guide. 1. ed. London: Earthscan, 1995.

\section{Capítulos de livro}

SOBRENOME, Inicial do nome. Título. In: SOBRENOME do ORGAZINADOR, Inicial do nome (Org.). Título da obra. Cidade da editora: Editora, Ano de publicação, páginas.

Exemplo:

ALMEIDA, L. T. Comércio e meio ambiente nas negociaçóes multilaterais. In: BRAGA, A. S.; MIRANDA, L. C. (Org.). Comércio e meio ambiente: uma agenda positiva para o desenvolvimento sustentável. Brasília: MMA/SDS, 2002. p. 97-134.

\section{Artigos em periódicos}

SOBRENOME do autor, Inicial. Título do artigo. Título da revista, volume, número, páginas do artigo, ano de publicação.

Exemplo:

ANYANWU, C. N. The technique of participatory research in community development. The Community Development Journal, v. 23, n. 4, p. 11-15, 1988. 


\section{Trabalho apresentado em evento}

SOBRENOME do autor, Inicial do nome. Título. In: EVENTO, Ano do evento, Cidade do Evento. Anais, página. Disponível em: <hiperlink $>$. Acceso em: data (formato Dia, mês, ano).

Exemplos:

SOUZA, L. S.; BORGES, A. L.; REZENDE, J. O. Influência da correção e do preparo do solo sobre algumas propriedades químicas do solo cultivado com bananeiras. In: REUNIÃO BRASILEIRA DE FERTILIDADE DO SOLO E NUTRIÇÃO DE PLANTAS, 21., 1994, Petrolina. Anais... Petrolina: EMBRAPA, CPATSA, 1994. p. 3-4.

ANDRADE, T. Inovação tecnológica e meio ambiente: dando um passo acima. In: ENCONTRO DA ASSOCIAÇÃO NACIONAL DE PÓS GRADUAÇÃO E PESQUISA EM AMBIENTE E SOCIEDADE, 2., 2004, Indaiatuba, SP. Anais... Indaiatuba: ANPPAS 1 CD-ROM.

ANDRADE, T. Inovação tecnológica e meio ambiente: dando um passo acima. In: ENCONTRO DA ASSOCIAÇÃO NACIONAL DE PÓS GRADUAÇÃO E PESQUISA EM AMBIENTE E SOCIEDADE, 2., 2004, , Indaiatuba, SP. Anais... Indaiatuba: ANPPAS 2004. Disponível em: <http://www.anppas.org.br/encontro_anual/encontro2/GT/GT01/thales. pdf >. Acesso em: 31 ago. 2007.

\section{Dissertações, teses e relatórios}

SOBRENOME, Inicial do nome. Título. Ano, Número de páginas. Dissertação - Centro, Universidade, Cidade.

Exemplo:

SERRANO, C. M. T. A invenção do Itatiaia. 1993. 179 f. Dissertação (Mestrado em Sociologia) - Instituto de Filosofia e Ciências Humanas, UNICAMP, Campinas.

\section{Trabalhos em meio-eletrônico}

Exemplo:

SÃO PAULO (Estado). Secretaria do Meio Ambiente. Tratados e organizações ambientais em matéria de meio ambiente. In:

Entendendo o meio ambiente. São Paulo, 1999. v. 1. Disponível em: <http::// www.bdt.org.br/sma/entendendo/atual.htm>. Acesso em: 8 mar. 1999.

\section{Artigos de periódico em meio eletrônico}

Exemplos:

AIKAWA, N. Visión Histórica de la Preparación de la Convención Internacional de la UNESCO para la Salvaguardia del Patrimonio Cultural Inmaterial. Museum Internacional. Patrimonio Inmaterial. Paris, UNESCO, 
n. 221-222, p. 140-155, 2003. Disponível em: <http://portal.unesco.org/ culture/en/ev.php>. Acesso em: 5 set. 2006.

JOLY, C. A. Acesso a recursos genéticos, repartição de benefícios e proteção dos conhecimentos tradicionais. Biota Neotrop., v. 5, n. 1, p. 3-3, 2005. Acesso em: 26 jun. 2006. Disponível em: <http://www.scielo.br/ scielo.php?script=sci_arttext\&pid=S1676-06032005000100001\&lng=en\& $\mathrm{nrm}=\mathrm{iso}>$.

ISSN 1676-0603. online.

Legislação BRASIL - SNUC. Lei no 9.985 de 18 de julho de 2000. Institui o Sistema Nacional de Unidades de Conservação e dá outras providências. Brasília, DF, 2000.

O envio espontâneo de qualquer colaboração implica automaticamente a cessão integral dos direitos autorais ao INCT-PPED. A revista não se obriga a devolver os originais das colaboraçóes enviadas. 
Desenvolvimento em Debate 


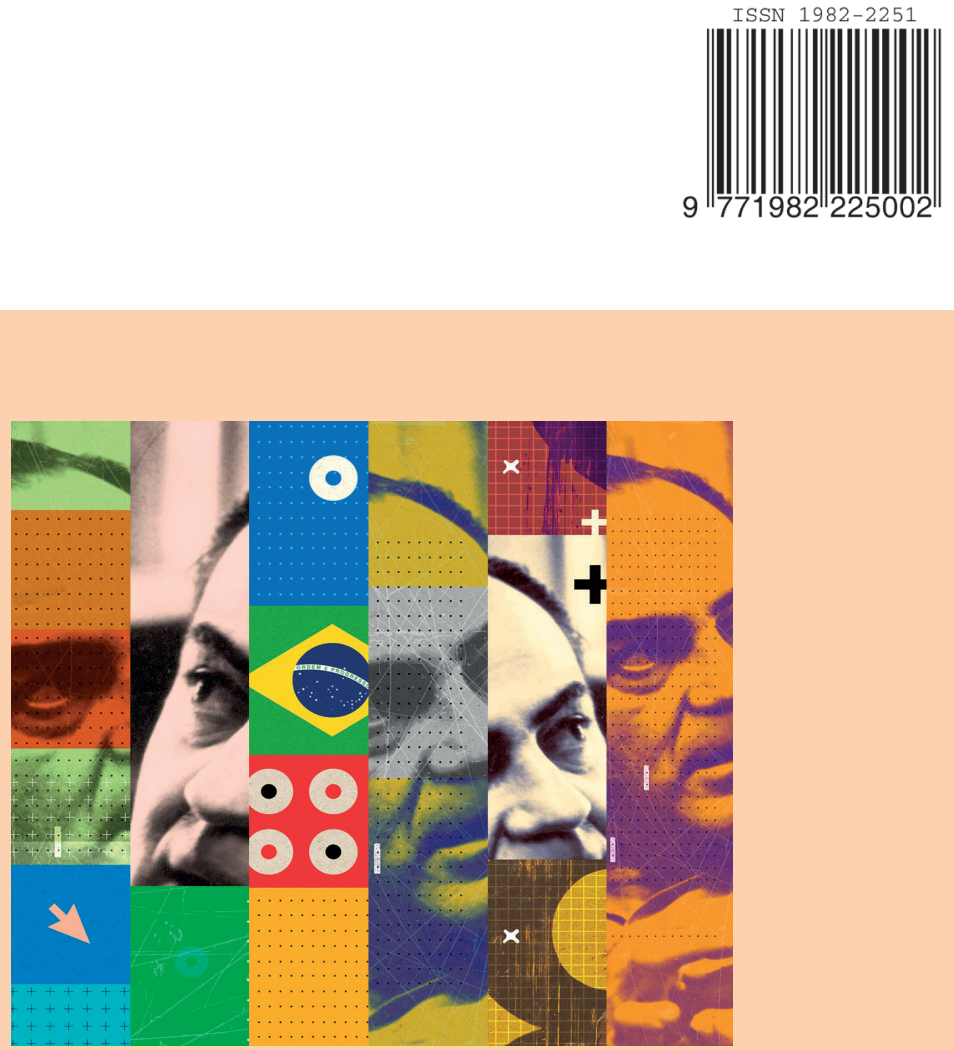

Desenvolvimento em Debate é uma publicação seriada semestral editada pelo Instituto Nacional de Ciência e Tecnologia em Políticas Públicas, Estratégias e Desenvolvimento (INCT-PPED) com o objetivo de divulgar trabalhos científicos originais da área de conhecimento interativa entre as Ciências Humanas, Sociais e Ambientais.

https://inctpped.ie.ufrj.br

https://inctpped.ie.ufrj.br/desenvolvimentoemdebate/index.html

\section{INCT/PPËD \\ Q \\ Politicas Públicas, Estratégias e Desenvolvimento \\ Conselho Nacional do Dosen
Cientifico o Tocnoldaice

